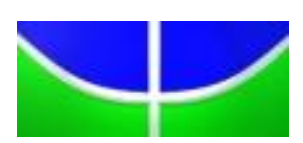

UNIVERSIDADE DE BRASÍLIA

INSTITUTO DE LETRAS

DEPARTAMENTO DE LINGUÍSTICA, PORTUGUÊS E LÍNGUAS CLÁSSICAS PROGRAMA DE PÓS-GRADUAÇÃO EM LINGUÍSTICA

\title{
PROPOSTA DE DICIONÁRIO DE APRENDIZAGEM: DESCRIÇÃO DE ALGUNS VERBOS NO CONTEXTO DO PORTUGUÊS DO BRASIL COMO SEGUNDA LÍNGUA
}

Flávia de Oliveira Maia Pires

Brasília-DF 


\section{FLÁVIA DE OLIVEIRA MAIA PIRES}

Tese submetida ao Programa de PósGraduação em Linguística da Universidade de Brasília. Área de Concentração: Teoria e Análise Linguística. Linha de Pesquisa: Léxico e Terminologia.

Orientadora: Profa. Dra. Enilde Faulstich

\section{Brasília-DF}


MAIA-PIRES, Flávia de Oliveira

M667p Proposta de dicionário de aprendizagem: descrição de alguns verbos no contexto do português do Brasil como segunda língua. / Flávia de Oliveira MAIA PIRES; orientador Enilde Faulstich. -- Brasília, 2015. $206 \mathrm{p}$.

Tese (Doutorado - Doutorado em Linguística) -Universidade de Brasília, 2015.

1. Dicionário de aprendizagem. 2. Dicionário informatizado. 3. Valência verbal. 4. Português como L2. 5. Contribuição do contexto para a significação. I. Faulstich, Enilde, orient. II. Título. 
BANCA EXAMINADORA

Professora Doutora Enilde Faulstich

Orientadora (Presidente) - LIP/UnB

Professora Doutora Patrícia Vieira Nunes Gomes

Membro Efetivo - INEP/MEC

Professor Doutor René Gottlieb Strehler

Membro Efetivo - LET/UnB

Professora Doutora Rozana Reigota Naves

Membro Efetivo - LIP/UnB

Professora Doutora Sandra Lucia Rodrigues da Rocha Membro Efetivo - LIP/UnB

Professora Doutora Cristina Madeira Coelho

Suplente - FE/UnB 
Dá instrução ao sábio, e ele se fará mais sábio ainda; ensina ao justo, e ele crescerá em prudência (Provérbios 9:9). 
Ao VERBO que se fez carne e habitou entre nós. 


\section{AGRADECIMENTOS}

A Deus, porque Dele, por meio Dele, e para Ele, são todas as coisas.

Ao meu amado e amigo Silvio, por ter trilhado comigo este caminho, cuidando de mim com amor, carinho e paciência.

Aos meus filhos Vinícius e Pedro, pelos momentos de alegria e pela compreensão.

À minha orientadora, $\operatorname{Prof}^{a} \operatorname{Dr}^{a}$ Enilde Faulstich, que me ensinou o significado de lĕgěre em uma aula que jamais esquecerei.

À minha mãe e ao meu pai, pelos incentivos e pelos carinhos.

Às minhas amigas Cleide, Cristiane, Giselle, Michelle e Patrícia, pelo companheirismo, pelo compartilhamento de ideias, dúvidas, alegrias, tristezas, angústias e vitórias.

Aos professores e aos funcionários do Departamento de Linguística, Português e Línguas Clássicas pelo apoio e pelas contribuições para o desenvolvimento do saber.

Ao meu amigo e especialista em desenvolvimento de software, pelo apoio técnico e pela paciência com o 'usuário’ do programa. 


\section{RESUMO}

Esta pesquisa foi desenvolvida no Centro de Estudos Lexicais e Terminológicos - Centro Lexterm - e está inserida na linha de pesquisa Léxico e Terminologia do Programa de PósGraduação em Linguística - PPGL - do Departamento de Linguística, Português e Línguas Clássicas - LIP- da Universidade de Brasília - UnB. A pesquisa é de natureza qualitativa e o método descritivo foi adotado para que os fatos de língua sejam coletados, observados, registrados e analisados. O objeto de estudo é a categoria verbo da língua portuguesa com o objetivo de elaborar uma proposta de dicionário de aprendizagem de verbos do Português do Brasil como segunda língua. As razões para a escolha deste objeto de estudo respaldamse na natureza do verbo, que ocupa lugar privilegiado nos enunciados, pois contém informações que dão movimento ao discurso, que engloba estados e eventos dentro do universo conceitual humano e, desse modo, seleciona e restringe os argumentos que o acompanham nos enunciados, por isso deve ser lexicografado dentro de base teórica e critérios linguísticos e extralinguísticos. Assim, esta pesquisa apresenta noções acerca da aprendizagem de língua, na perspectiva de segunda língua -L2, da natureza do léxico, dos atributos do verbo e dos princípios teóricos da lexicografia para aprendizagem de línguas. A pesquisa sustenta-se na base epistemológica da Gramática Discursivo-Funcional - GDF de Hengeveld e Mackenzie (2008, 2010), nos estudos teóricos de Chafe (1979), na teoria de valência Borba (1996 e 2003) e da Lexicologia e da Lexicografia, de Rey-Devobe (1971, 1984), Haensch (1982, 1997), Faulstich (1990, 1993, 1998 e 2010) e Lara (1997). A GDF inclui a interação verbal na análise de língua, além das expressões linguísticas, e inclui o componente conceitual, componente contextual, componente de saída na interação verbal, que se interligam ao componente gramatical por meio de operações de formulação e de codificação, seguindo uma organização hierárquica, a top down. Os estudos de Chafe (1979) e Borba (1996) apresentam o sistema sintático-semântico que descreve características dos verbos como de estado, de ação, de processo e de estado-processo, além das informações morfossitáticas como número, pessoa, tempo e modo. A análise dos significados dos verbos é apresentada segundo aspectos sintático-semânticos em enunciados relacionados a 17 contextos situacionais, a saber: alimentação, atividades comerciais, atividades domésticas, clima e tempo, crime e violência, educação, esporte, lazer, moradia, profissão e trabalho, relações sociais, trânsito e transporte, vestimentas e indumentárias e viagem e hospedagem. O resultado deste estudo é a apresentação da proposta Dicionário de aprendizagem de verbos do português do Brasil como segunda língua-Dicverb/PL2 -, para aprendizes da língua portuguesa, em fase inicial de aprendizagem. O Dicveb/PL2 visa a oferecer meios que auxiliem a aprendizagem dos verbos de modo eficiente, dentro de contextos linguístico, situacionais e culturais existentes na língua portuguesa falada no Brasil.

Palavras-chave: Dicionário de aprendizagem. Dicionário Informatizado. Valência verbal. Segunda língua. Componente contextual. Componente conceitual. 


\begin{abstract}
This research was developed in Centro de Estudos Lexicais e Terminológicos - Centro Lexterm - and it is inserted in the search line Lexicon and Terminology of the Graduate Program in Linguistics - PPGL - Department of Linguistics, Portuguese and Classical Languages - LIP- University of Brasilia - UnB. The research is qualitative and the descriptive method was adopted for the facts of language are collected, observed, recorded, analyzed. The study object is the verb category of the Portuguese language in order to draft a Portuguese verb learning dictionary of Brazilian Portuguese as a second language - L2. The reasons for choosing this object is because the nature of the verb, that is a kind of word that occupies a special place in the statements, because it contains information that gives movement to the speech, this is a type of word which encompasses states and events within the human conceptual universe and thus selects and restricts the arguments that follow it in the statements, so it should be described in dictionary within theoretical basis and linguistic and extralinguistic criteria. Thus, this research presents notions about language learning from the perspective of second language -L2, the nature of the lexicon, the verb attributes and theoretical principles of pedagogical lexicography. The research supports on the epistemological basis of Functional Discourse Grammar - GDF Hengeveld and Mackenzie (2008, 2010), Chafe (1979) and Borba (1996 and 2003), Lexicology and Lexicography, ReyDevobe (1971, 1984), Haensch (1982, 1997), Faulstich (1990, 1993, 1998 and 2010) and Lara (1997). The GDF includes discursive interaction in the language analysis beyond linguistic expressions, and includes conceptual component, context component output component verbal interaction which interconnect the grammar component by means of formulation and coding operations, following a hierarchical organization, the top down. The study of Chafe (1979) and Borba (1996) presents the syntactic-semantic system that describes characteristics of verbs such as state, action, process and state-process, in addition to morphosyntactic information such as number, person, time and mode. The analysis of the meanings of the verb is presented according to syntactic-semantic aspects in statements related to 17 situational contexts, namely food, business activities, domestic activities, climate and weather, crime and violence, education, sport, leisure, housing, occupation and work, social relations, traffic and transportation, clothing and costumes and travel and lodging. The result of this study is presenting the proposal Dicionário de aprendizagem de verbos do português do Brasil como segunda língua - Dicverb/PL2 -, for beginners of Portuguese Language. The Dicveb/PL2 aims at offering means to assist in verb learning efficiently within Brazilian linguistic, situational and cultural contexts.
\end{abstract}

Keywords: Learning Dictionary. Computerized Dictionary. Verbal Valencia. Second language. Component context. Conceptual component. 


\section{LISTA DE FIGURAS}

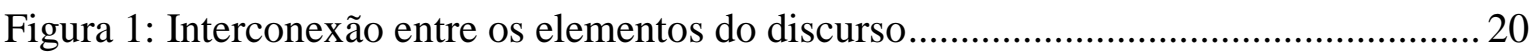

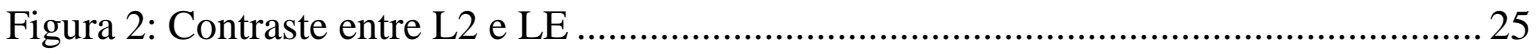

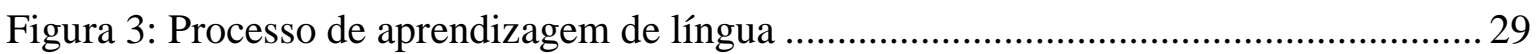

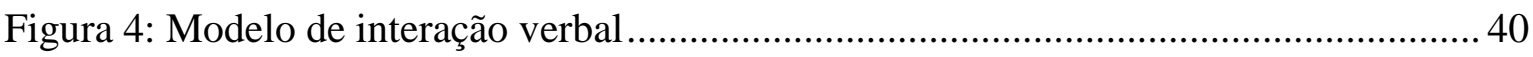

Figura 5: A GDF como parte de uma teoria mais ampla da interação verbal ...................... 41

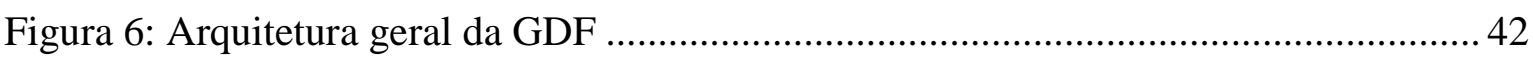

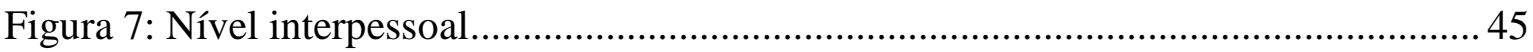

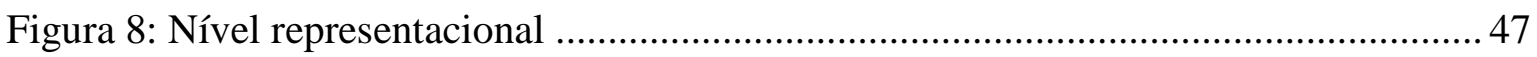

Figura 9: Representação esquemática, revisada por Cornish, da concepção de Connolly .. 53

Figura10:Relação entre as três principais partes de contexto - situacional, textual e

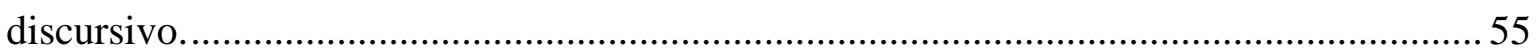

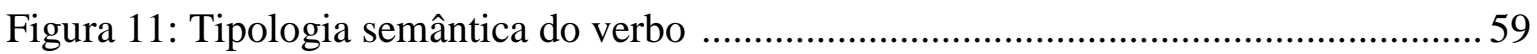

Figura 12: Representação do software AntConc 3.2.4w ................................................... 75

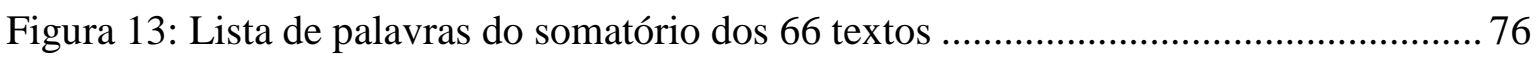

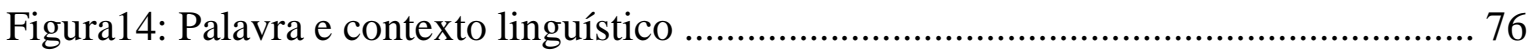

Figura 15: Página de cadastramento da macroestrutura no banco de dados..................... 147

Figura 16: Exemplo de recurso para cadastramento de dados .........................................148

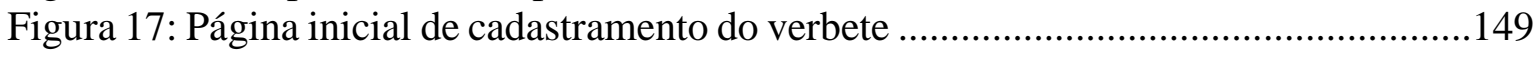

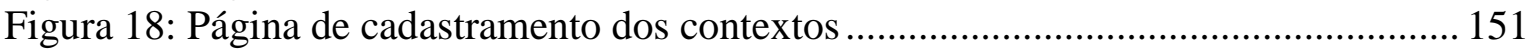

Figura 19: Página de cadastramento de equivalentes e exemplos de uso.......................... 152

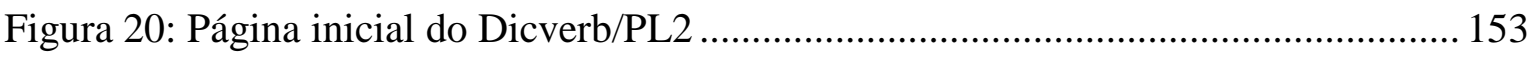

Figura 21: Página do guia de uso do Dicverb/PL2 ........................................................ 154

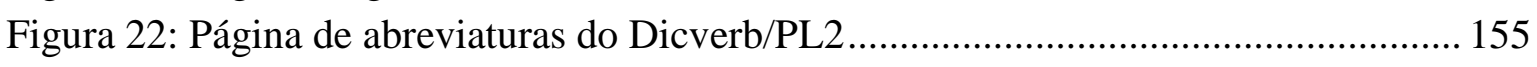

Figura 23: Página do quadro fonético do Dicverb/PL2 .................................................. 156

Figura 24: Página de referências bibliográficas do Dicverb/PL2 ..................................... 157

Figura 25: Página inicial com recurso de busca do Dicverb/PL2 …............................... 158

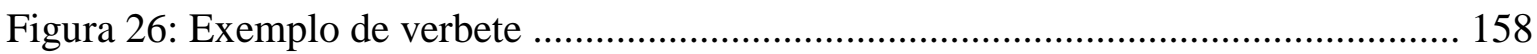

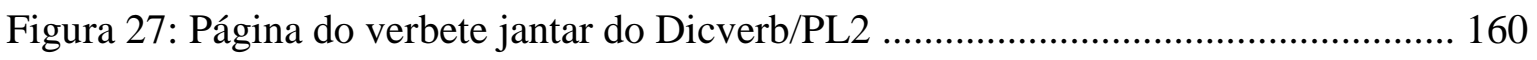

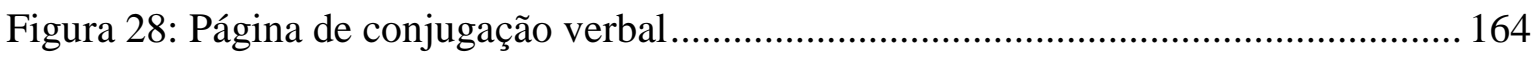

Figura 29: Página do verbete jantar do Dicverb/PL2 - definição, complementos, exemplos de uso e correspondente em inglês. 


\section{SUMÁRIO}

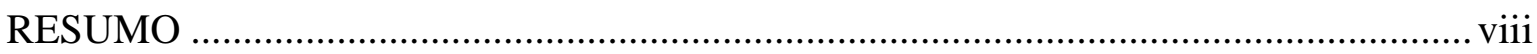

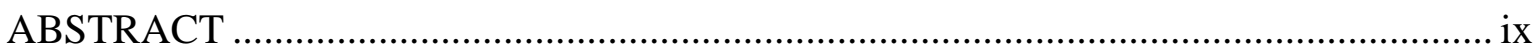

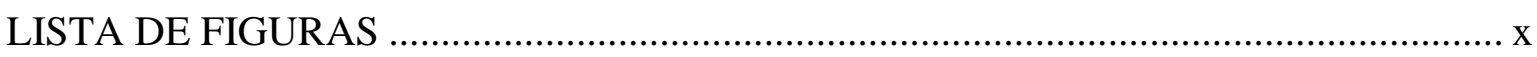

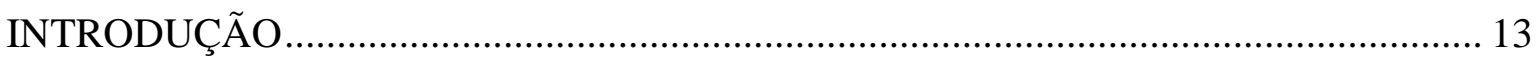

CAPÍTULO 1 - DICIONÁRIOS DE APRENDIZAGEM DE LÍNGUA ............................ 18

1.1. Noções acerca de aprendizagem de língua ........................................................... 19

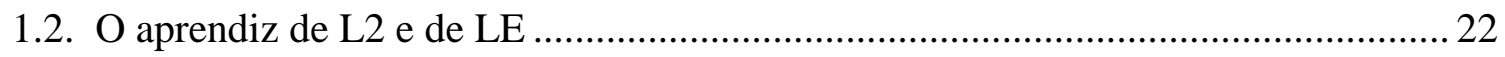

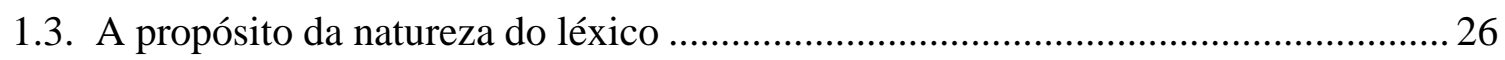

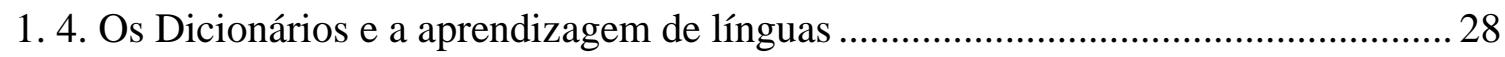

1.4.1. Dicionários bilíngues e dicionários semibilíngues .......................................... 32

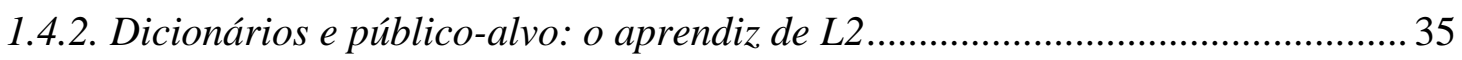

1.4.3. A necessidade de dicionários para aprendizes de PSL ..................................... 36

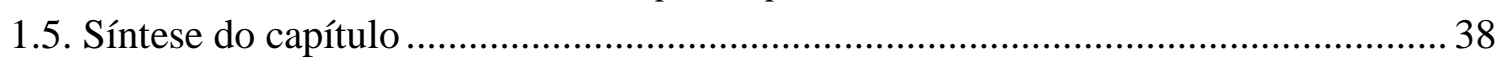

CAPÍTULO 2 - O CONTEXTO COMO AGENTE CONTRIBUIDOR PARA A

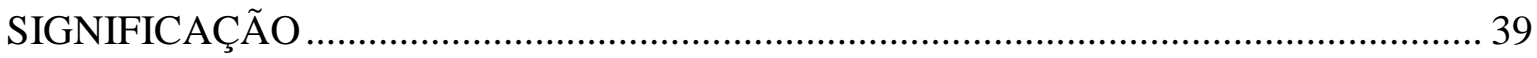

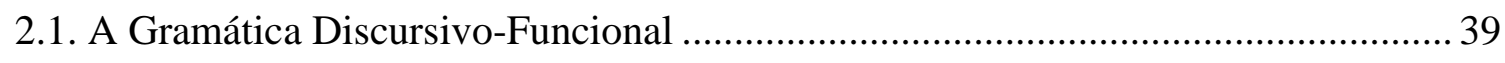

2.1.1. Nivel interpessoal e nível representacional ................................................... 44

2.2. A inter-relação do contexto com a Gramática Discursivo-Funcional........................ 49

2. 2. 1. Texto, contexto e discurso no componente contextual da GDF ........................54

2.3. Atributos do verbo no processo de formulação e de codificação ...............................56

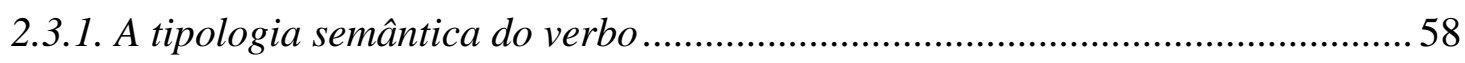

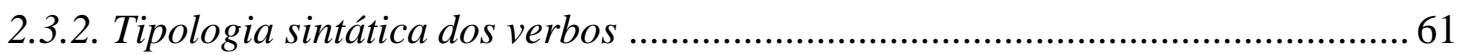

2.4. Os verbos segundo as diretrizes conceitual, contextual, semântica e sintática..........63

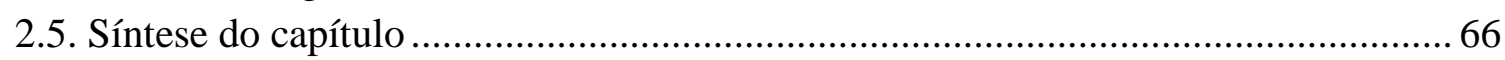

CAPÍTULO 3 - METODOLOGIA PARA ELABORAÇÃO DE UMA PROPOSTA DE

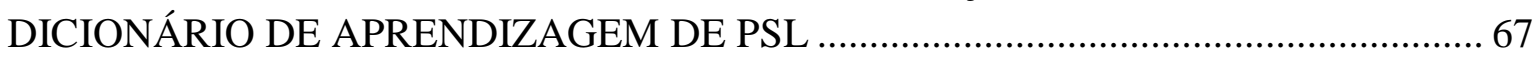

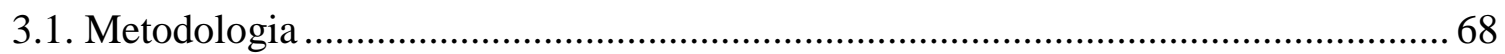

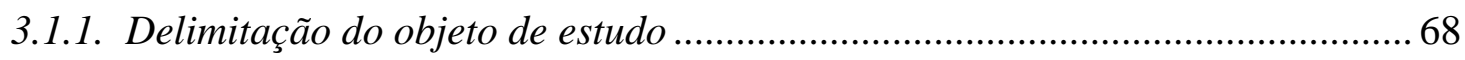

3.1.2. Delimitação do perfil do público-alvo do dicionário de PSL .............................69 69

3.1.3. Seleção dos contextos do cotidiano brasileiro em que ocorrem os verbos ........ 69

3.1.4. Metodologia para recolha e tratamento do corpus para suporte da análise .... 72

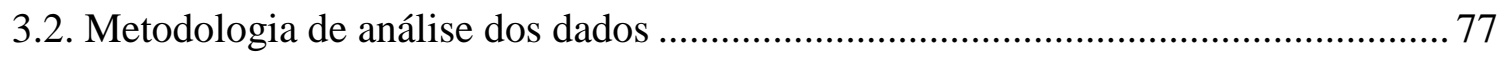

3.2.1. O tratamento dos verbos quanto à polissemia e à homonímia .......................... 84

3.3. Metodologia para a seleção de itens de composição da microestrutura ................... 86

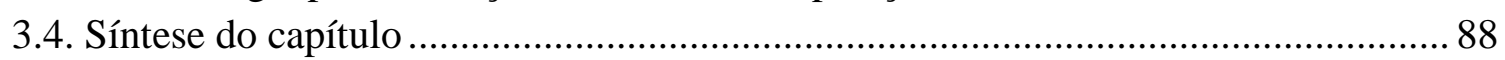

CAPÍTULO 4 - LEXICOGRAFIA PARA L2: ASPECTOS DA ESTRUTURA DE

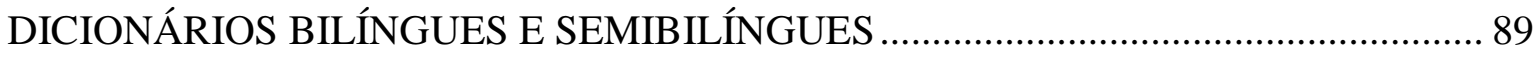

4.1. Breve percurso da lexicografia antiga à contemporânea ......................................... 89

4.2. A tipologia das obras lexicográficas: dicionários bilíngues e dicionários

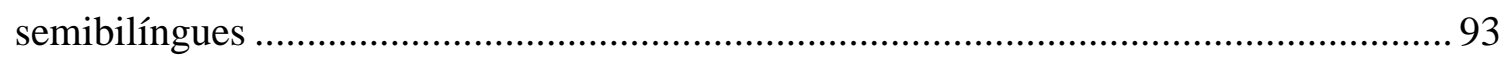

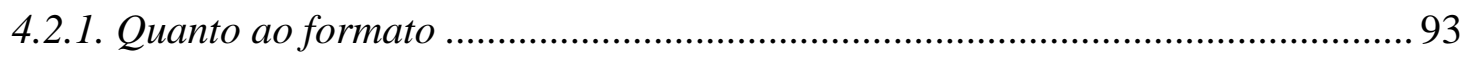




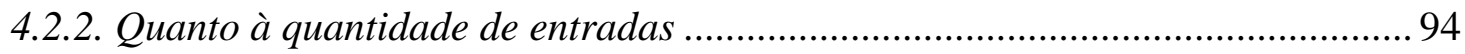

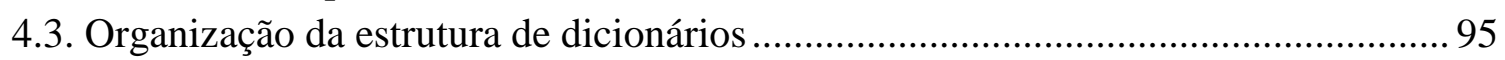

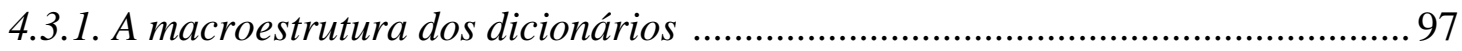

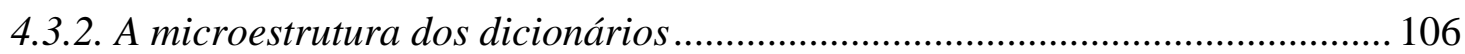

4.3.3. Problemas dos dicionários bilíngues quanto ao público-alvo. ......................... 109

4.3.4. A tecnologia aliada à construção de dicionários atuais ................................. 118

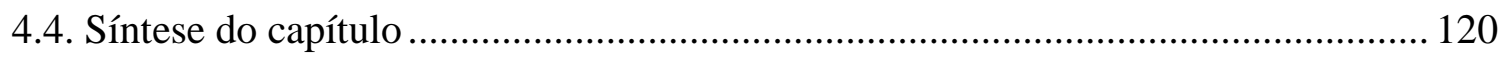

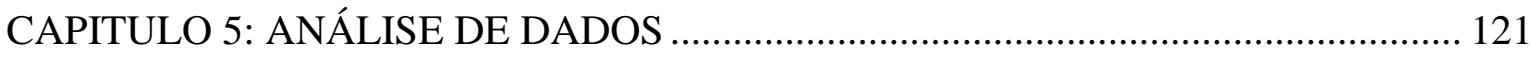

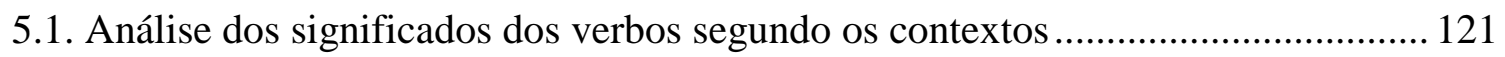

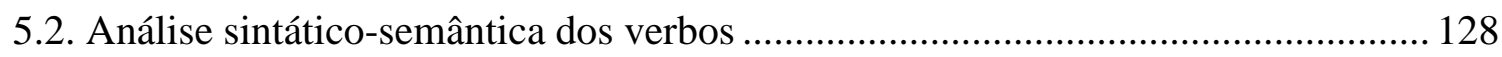

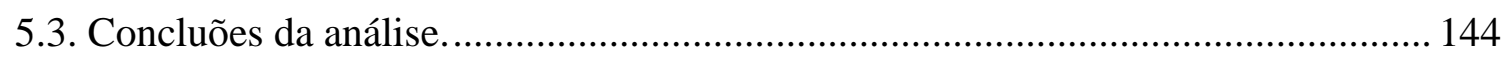

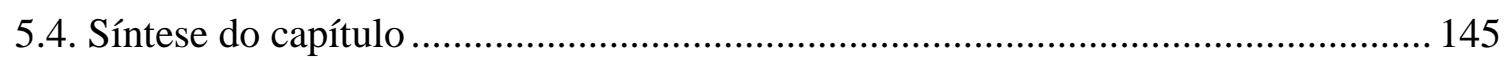

CAPÍTULO 6 - PROPOSTA PARA DICIONÁRIO DE APRENDIZAGEM DE PSL .. 146

6.1. A proposta do Dicionário de aprendizagem de verbos do português do Brasil como

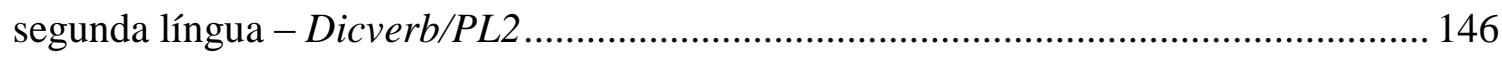

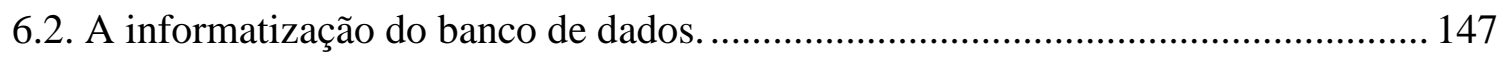

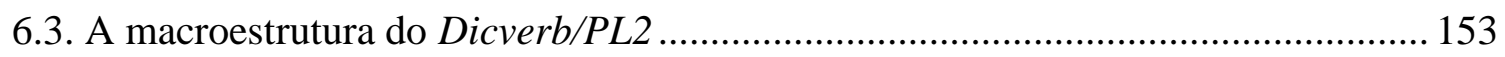

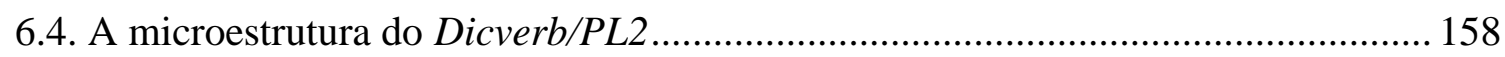

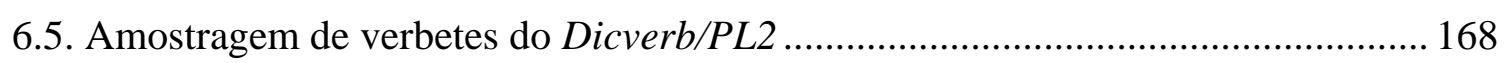

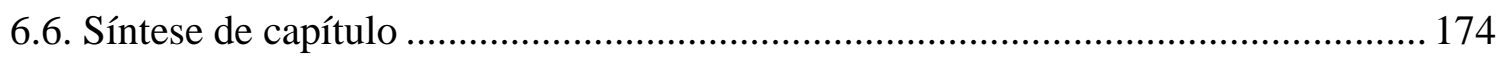

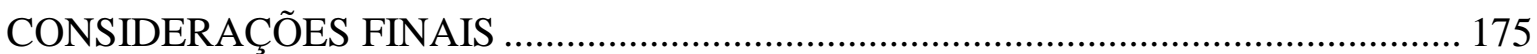

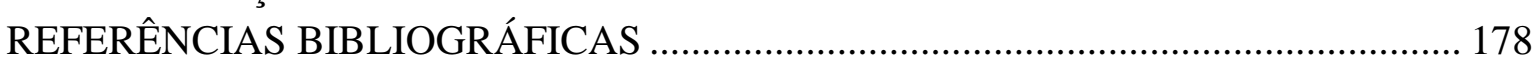

Anexo 1 - Lista de verbos identificados na primeira etapa da pesquisa .......................... 179

Anexo 2 - Guia de uso do Dicverb/PL2 _.................................................................. 195

Anexo 3 - Conjugação dos verbos da amostragem ........................................................ 200 


\section{INTRODUÇÃO}

Este estudo está inserido na linha de pesquisa Léxico e Terminologia do Programa de Pós-Graduação em Linguística - PPGL - do Departamento de Linguística, Português e Línguas Clássicas - LIP- da Universidade de Brasília - UnB. O objeto de estudo é um recorte da categoria verbo do português do Brasil, com o objetivo de elaborar uma proposta de modelo de dicionários de aprendizagem de verbos do português como segunda língua (PSL). O estudo concebe aspectos da lexicografia para um público que se encontra em situação de aprendizagem de segunda língua (L2), em que são contemplados aspectos linguísticos e extralinguísticos. Para alcançar nosso objetivo, esta pesquisa propõe-se a: i) identificar os princípios teóricos da lexicografia para aprendizagem de línguas; ii) analisar a macroestrutura e a microestrutura de dicionários bilíngues e semibilíngues para a aprendizagem de línguas; iii) analisar as informações semânticas, sintáticas e pragmáticas dos verbos da língua portuguesa em contextos de uso dos brasileiros; iv) propor a organização da microestrutura de um dicionário de PSL que ofereça ao aprendiz informações que o auxiliem na aprendizagem dos verbos da língua portuguesa; e v) incluir, no processo de aprendizagem, questões de fonética, de morfologia, de sintaxe, de semântica, de pragmática da língua portuguesa, assim como da cultura brasileira, por meio do léxico.

$\mathrm{Na}$ tese que defendemos, o princípio é que o verbo seleciona os elementos que o acompanham na composição dos enunciados presentes no evento comunicativo associado às informações pré-linguísticas que envolvem conceito, contexto cultural e contexto situacional. Para isso, consideramos como hipótese que a seleção dos elementos linguísticos como os complementos verbais é feita pelo verbo como resultado da combinação dos traços gramaticais, semânticos e pragmáticos que se dá no discurso. Essa proposição sustenta-se na base epistemológica da Gramática Discursivo-Funcional - GDF de Hengeveld e Mackenzie $(2008,2010)$ que inclui a interação verbal na análise de língua, incorporando as expressões linguísticas ao modelo de interação verbal em que o componente conceitual, o componente contextual e o componente de saída se interligam ao componente gramatical por meio de operações de formulação e de codificação, seguindo uma organização hierárquica, a top down. Sustenta-se também na base epistemológica de Chafe (1979) que descreve características dos verbos como de estado, de ação, de processo e de estado-processo, além das informações morfossintáticas como número, pessoa, tempo e modo, que se organizam e demonstram a centralidade do verbo dentro do universo conceitual humano, que engloba 
estados e eventos. Esta pesquisa, ainda considera a teoria de valência de Borba (1996) que inclui as características sintático-semânticas dos verbos e os descreve como monovalente, bivalente, trivalente e tetravalente. Diante disso, a elaboração de uma proposta de dicionário de aprendizagem de verbos do português do Brasil como segunda língua para iniciantes, com o recurso de ferramentas tecnológicas para processamento e análise de dados, deve apresentar significados com base em contextos cultural e situacional para que a estrutura do dicionário contenha informações linguística e extralinguística de acordo com o uso do item lexical no quotidiano. Os estudos de base desta pesquisa têm como fundamentos para a descrição lexicográfica Rey-Devobe (1971, 1984), Haensch (1982, 1997), Faulstich (1990, 1993, 1998 e 2010), Lara (1997) e Borba (2003).

A motivação para a realização desta pesquisa encontra-se em alguns questionamentos não respondidos em estudos anteriores, associados à prática de docência em PSL. Na graduação, no projeto de iniciação científica ${ }^{1}$, estudamos os aspectos relacionados à aquisição lexical por falantes do português como L2 e verificamos que "ao ler um texto, escrito ou oral, da língua que está aprendendo, o leitor tenta depreender, por meio do léxico que lhe é apresentado, o conteúdo do que lhe está sendo exposto, por meio das relações textuais" (FAULSTICH e MAIA-PIRES, 2006, p. 5). O produto final de nossa pesquisa de iniciação científica foi um inventário lexical composto por 247 palavras referentes ao meio urbano, ao meio rural, à praia, à fauna, à flora, ao clima e ao trânsito, distribuídas entre as categorias substantivos, adjetivos e verbos. O estudo serviu de base para a elaboração de três unidades didáticas que foram utilizadas no projeto de conclusão de curso de Licenciatura em Letras Português do Brasil como Segunda Língua - PBSL, na Universidade de Brasília.

No mestrado, identificamos uma lacuna, nos livros didáticos, referente a itens lexicais de urbanismo, principalmente, os itens relacionados à cidade de Brasília. Os aprendizes de PSL não reconheciam essas estruturas lexicais apresentadas nos livros didáticos, que, na maioria, apresentavam adaptações de livros de inglês, de espanhol ou de outra língua diferente do Português do Brasil e que, por isso, não representavam a organização urbana da Capital do Brasil. Esse fato nos estimulou a desenvolver uma pesquisa terminológica na área de urbanismo, que resultou na elaboração de um Glossário da estrutura urbana do Plano Piloto de Brasília com 270 itens.

\footnotetext{
${ }^{1}$ Projeto de Iniciação Científica - PIBIC - intitulado Aquisição do léxico na aprendizagem do português como segunda língua, orientado pela Profa. Dra. Enilde Faulstich, em 2006.
} 
Na prática de docente e de pesquisadora, reconhecemos ausência de dicionários direcionados aos estudantes de PSL. Os estudantes, geralmente, recorrem a dicionários elaborados para atender estudantes brasileiros que estão aprendendo uma língua estrangeira como material de estudo para aprender o português do Brasil. Verificamos, conforme materiais disponíveis nas livrarias e em sites de compra e venda, a existência de muitos dicionários para o ensino de línguas estrangeiras para brasileiros, como inglês/português, espanhol/português, francês/português, alemão/português, e "muita pesquisa e trabalhos realizados principalmente para o Inglês, Espanhol, Alemão, Francês e Japonês", segundo Vieira e Lima (2001, p. 10). Porém, há carência de pesquisas e de dicionários para aprendizagem, principalmente, para o público de PSL. Diante do contexto políticoeconômico-social do Brasil e da escassez de materiais voltados a esse público, entendemos que nossa pesquisa colaborará para o preenchimento dessa lacuna nos estudos lexicológicos e lexicográficos de PSL. A elaboração de um modelo de dicionário com base teórica favorável à aprendizagem de PSL é urgente, assim como pesquisas na área.

Desse modo, será apresentado o percurso feito para a elaboração de uma proposta de modelo de dicionário de aprendizagem de verbos do português como segunda língua, que demonstrará as concepções acerca da natureza do léxico, do papel do contexto na aprendizagem e no uso da língua, dos dicionários bilíngues e semibilíngues e das relações de âmbito linguístico e extralinguístico, descrevendo as características e as funções para a aprendizagem de segunda língua.

Organizamos esta tese em seis capítulos. No primeiro capítulo, são expostos os atributos do léxico, sua relação com os dicionários e com os usuários e aprendizes de língua. Abrange noções de aprendizagem de língua e as diferenças entre o aprendiz de segunda língua (L2) e o aprendiz de língua estrangeira (LE). Encerramos este capítulo com a demonstração das relações entre os dicionários e o público-alvo, com ênfase para o aprendiz de L2 e a necessidade de dicionários para estudantes de português do Brasil como segunda língua. Procuramos destacar os problemas decorrentes da falta de dicionários para estudantes de PSL, e ressaltamos a urgência em criar dicionários para esse público específico, que contemplem a diversidade brasileira refletida na língua portuguesa falada no Brasil.

No segundo capítulo, apresentamos o embasamento teórico que nos auxiliou a identificar a importância do contexto linguístico e do contexto extralinguístico na compreensão e na produção de enunciados por meio do léxico. Nossa pesquisa adota os estudos relacionados à teoria da Gramática Discursivo-Funcional, porque, como Connolly 
(2007, p. 11) afirma, "an important and admirable characteristic of the FDG framework is that it takes very seriously the fact that utterances are produced and understood in context" 2 . Assim, apresentamos conceitos da Gramática Discursivo Funcional (GDF) e ilustrações que venham auxiliar a compreensão da teoria. Destacamos o componente conceitual e o componente contextual pela inter-relação com o componente gramatical no âmbito da GDF. Além disso, descrevemos os atributos do verbo de acordo com Chafe (1979) e Borba (1996 e 2003), para apresentar a tipologia semântica e sintática, com vistas a compreender a centralidade dessa categoria lexical na produção e na compreensão de enunciados.

No terceiro capítulo, apresentamos a metodologia para elaboração de nossa proposta de dicionário de aprendizes de PSL. Descrevemos a delimitação do objeto de estudo e o perfil do público-alvo de nossa proposta de dicionário. Indicamos as diretrizes para a seleção dos contextos do cotidiano brasileiro em que ocorrem os verbos. A metodologia para recolha e tratamento do corpus e a metodologia de análise de dados são expostas. Além disso, descrevemos o processo de seleção de itens de composição da macroestrutura e da microestrutura do dicionário de aprendizagem de verbos do português como L2. Esse percurso dá corpo à pesquisa. Desse modo, as respostas encontradas para as questões que estão no âmago da metodologia adotada são expostas, assim como os motivos que nos levaram a fazer certas escolhas.

No quarto capítulo, expomos o percurso da lexicografia, de modo sucinto, com ênfase no desenvolvimento das obras bilíngues e semibilíngue e com a finalidade de identificar os elementos de composição da macroestrutura e da microestrutura desses tipos de dicionários. Com esse capítulo, identificamos aspectos das estruturas de dicionários para buscar diretrizes, de acordo com a função e o público-alvo da obra, para nossa proposta. Expomos algumas diretrizes que orientam a tipologia lexicográfica e que refletem na variedade de tipos de dicionários distintos encontrados em bibliotecas, livrarias e internet. Cotejamos algumas obras para confrontar a composição da macroestrutura e da microestrutura. Essas diretrizes e o cotejo feito serviram de base para identificarmos as principais características que nortearam o nosso dicionário de aprendizagem de verbos do português como L2. Por fim, avaliamos como as inovações tecnológicas podem promover melhor uso e interação entre dicionário e aprendiz.

\footnotetext{
${ }^{2}$ Uma característica importante e admirável da Gramática Discursivo-Funcional - GDF - é a de que considera seriamente o fato de enunciados serem produzidos e entendidos em contexto.
} 
O quinto capítulo contém a análise dos dados, cujos resultados conduziram-nos à elaboração da microestrutura do dicionário de aprendizagem de verbos do português como segunda língua. Apresentamos a análise dos significados dos verbos segundo contextos relacionados aos 17 contextos situacionais que serão abordados em nosso dicionário; a análise sintático-semântica dos verbos e os resultados da análise.

No sexto e último capítulo, o produto final desta pesquisa é apresentado, a proposta do Dicionário de aprendizagem de verbos do português do Brasil como segunda língua Dicverb/PL2 - para aprendizes em fase inicial de aprendizagem da língua portuguesa. Adiantamos que, por meio do resultado deste estudo, das análises e das reflexões, nossa proposta visa a oferecer meios que auxiliem a aprendizagem dos verbos de modo eficiente, dentro de contextos linguísticos, situacionais e culturais existentes na língua portuguesa do Brasil.

Para finalizar, posteriormente aos capítulos, apresentamos as considerações finais, as referências bibliográficas e os anexos. Informamos, ainda, que as figuras com a referência Maia-Pires (2015) são de nossa autoria para os fins desta tese e que os textos que estavam em língua estrangeira foram traduzidos para a língua portuguesa sob nossa responsabilidade. 


\section{CAPÍTULO 1 - DICIONÁRIOS DE APRENDIZAGEM DE LÍNGUA}

No processo de ensino e de aprendizagem de língua, o léxico tem papel de destaque por ser um dos componentes do dicionário, seja aquele que o falante tem armazenado na mente, seja o descrito em obras lexicográficas. A relevância atribuída ao léxico é que este possibilita a expressão do pensamento com maior precisão, por isso, há o empenho do aprendiz para aprender o léxico de uma língua.

Assim sendo, encontramos estudos que afirmam que "o ensino do léxico, assim como do uso de dicionário, suscita interesse na medida em que as palavras são pilares da interação linguística” (GOMES, 2011, p.142), por isso os dicionários são incluídos como meio para a aprendizagem de léxico, pois "no contexto escolar de leitura e produção de textos, a consulta ao dicionário constitui um importante exercício de fixação e expansão de vocabulário, quanto a aspectos de forma ou de conteúdo" (CARVALHO, 2011, p. 87).

A importância da aprendizagem do léxico também é considerada pelo Ministério da Educação, como está expresso no livro Com direito à palavra: dicionários em sala de aula:

\footnotetext{
um dicionário pode ser um instrumento bastante valioso para a aquisição de vocabulário e para o ensino e a aprendizagem da leitura e da escrita; e isso, para todas as áreas e para todas as horas, já que ler e escrever, dentro e fora da escola, fazem parte de muitas outras atividades (BRASIL, MEC/SEF, 2012, p. 18).
}

Essas citações nos levam ao reconhecimento de que o dicionário é material essencial no contexto de ensino e de aprendizagem de língua, como primeira língua - L1, segunda língua - L2 - ou língua estrangeira - LE. Por conseguinte, há um incentivo e um interesse de estudos sobre a lexicografia pedagógica nos últimos anos.

Nessa linha, optamos por apresentar, neste capítulo, os atributos do léxico, na composição de dicionários para usuários e aprendizes de língua. Organizamos o conteúdo com o seguinte sumário: Noções acerca de aprendizagem de língua; O aprendiz de L2 e de LE; A propósito da natureza do léxico; Os dicionários e a aprendizagem de língua; Dicionários e público-alvo: o aprendiz de L2; A necessidade de dicionários para estudantes de português do Brasil como segunda língua; e Síntese do capítulo. 


\subsection{Noções acerca de aprendizagem de língua}

Ao longo do desenvolvimento, o ser humano adquire informações culturais, históricas e sociais em um processo contínuo. Constrói conceitos e, assim, interage no meio, organizando uma rede de relação de significados. Nesse contexto, o homem, por critérios linguísticos e sociais, defronta a necessidade de escolher o melhor modo de transmitir seu pensamento segundo várias alternativas que a língua oferece. Isso faz com que o léxico seja visto como elemento relevante nesse processo, como verificamos na afirmação de Vygotsky (1993, p. 104), quando assevera que "o significado de uma palavra representa um amálgama tão estreito do pensamento e da linguagem que fica difícil dizer se é um fenômeno da fala ou um fenômeno do pensamento". Situações como eu ia dizer algo, mas me esqueci da palavra demonstram a ligação entre o significado de determinado item lexical e o pensamento. Segundo Aitchison (1994, p. 3), "as pessoas usam palavras a todo o momento, todos precisam de palavras, uma pessoa tem contato com milhares de palavras no decorrer do dia; sem as palavras, as pessoas poderiam estar um pouco perdidas". Portanto, aprender uma palavra significa aprender parte da língua, expressar um pensamento, não estar perdido; significa interligar indivíduo, língua, história e cultura de certa comunidade de fala, conforme registram Oliveira e Isquerdo (2001, p. 9):

O léxico, saber partilhado que existe na consciência dos falantes de uma língua, constitui-se no acervo do saber vocabular de um grupo sóciolinguístico-cultural. Na medida em que o léxico configura-se como a primeira via de acesso a um texto, representa a janela através da qual uma comunidade pode ver o mundo, uma vez que esse nível da língua é o que mais deixa transparecer os valores, as crenças, os hábitos e costumes de uma comunidade, como também, as inovações tecnológicas, transformações socioeconômicas e políticas ocorridas numa sociedade. Em vista disso, o léxico de uma língua conserva uma estreita relação com a história cultural da comunidade. Desse modo, o universo lexical de um grupo sintetiza a sua maneira de ver a realidade e a forma como seus membros estruturam o mundo que os rodeia e designam as diferentes esferas do conhecimento. Assim, na medida em que o léxico recorta realidades do mundo, define, também, fatos de cultura.

Em vista dessas propriedades culturais do léxico, na aprendizagem de língua, há a necessidade de materiais pedagógicos que demonstrem a riqueza das línguas na descrição do mundo. Há necessidade de que, por meio do saber lexical, o aprendiz, além do conhecimento linguístico, perceba que, de fato, "en las distintas culturas y en distintas 
épocas, los hombres han concebido la realidade de modo muy diferente, y de que el mismo hombre puede cambiar sus ideas "3" (WERNER, 1982, p. 30), e perceba que, assim como o homem, assim como a sociedade, a língua muda. Desse modo, o processo de aprendizagem precisa conduzir o aprendiz a compreender que essas mudanças, representadas pelo léxico da língua, consideram a relação linguagem e realidade, tanto por parte de quem está produzindo quanto de quem está recebendo os enunciados. Na produção e na compreensão do discurso cotidiano, há interconexão entre o pensamento, os fatores linguísticos e os fatores extralinguísticos, e o léxico exerce papel central na conexão entre esses elementos.

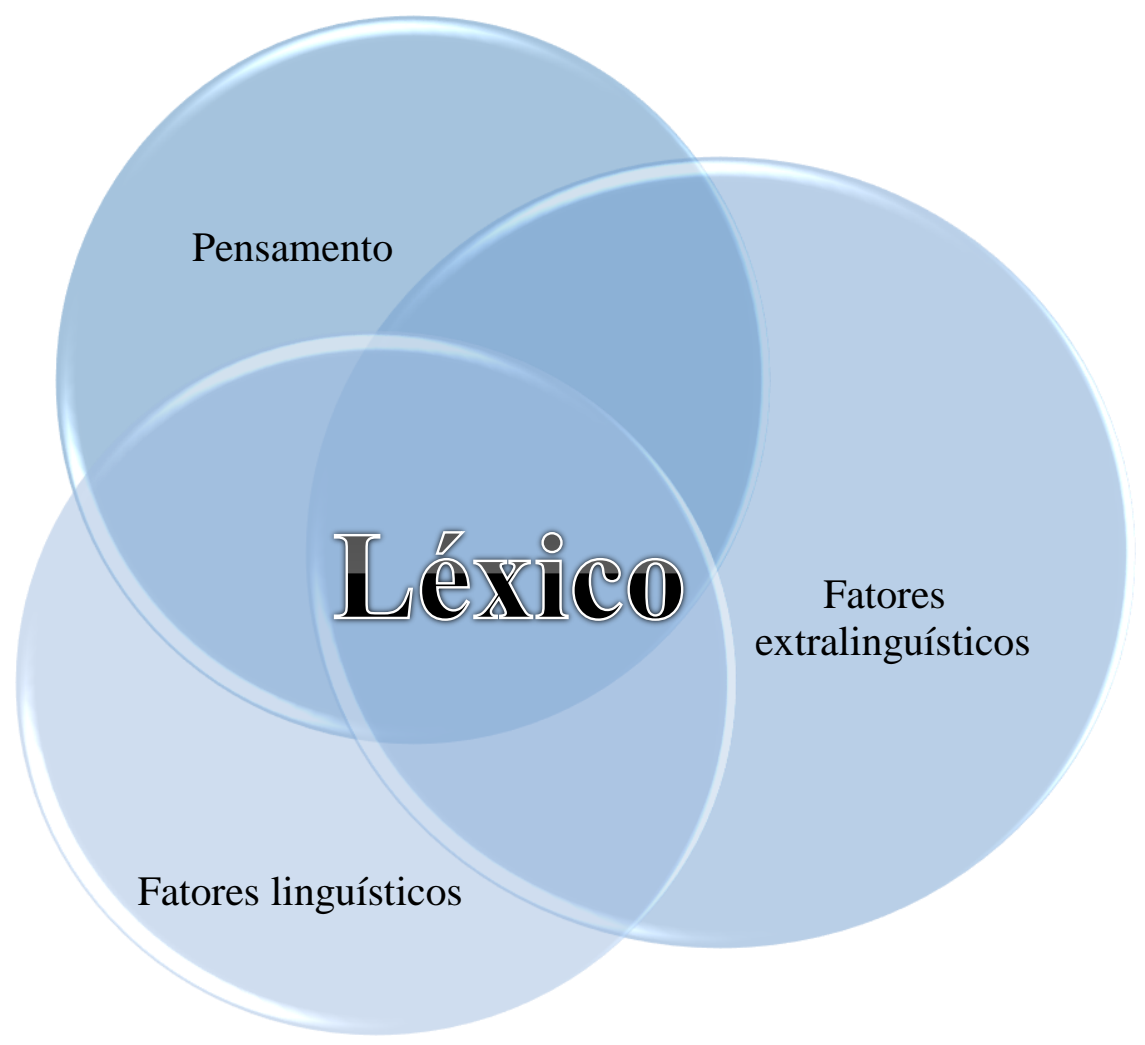

Figura 1: Interconexão entre os elementos do discurso

Fonte: MAIA-PIRES, 2015.

Como representado na figura anterior, a aprendizagem de língua envolve o pensamento; os fatores linguísticos que apresentam a relação do léxico com a gramática nos aspectos fonológico, ortográfico, morfológico, sintático, semântico, pragmático; e os fatores

\footnotetext{
${ }^{3}$ Em culturas distintas e em épocas distintas, os homens concebem a realidade de modo muito diferente, e o mesmo homem pode mudar suas concepções.
} 
extralinguísticos que apresentam as experiências, a visão de mundo, a organização social, a história e a cultura da comunidade de fala. Para esse conjunto, convergem "características sistemáticas que têm a propriedade de se referir a entidades da realidade" (FAULSTICH, 1997, p. 72).

Porém, para que um estudante aprenda uma língua, é preciso que a aprendizagem seja efeito de passos seguros, como declara Laufer (1997, p. 141) acerca da palavra:

1. saber sua forma oral e escrita, pois é preciso saber como se pronuncia e como se escreve;

2. saber sua estrutura de base, suas derivações mais comuns e a suas flexões;

3. saber as suas propriedades sintáticas e o seu comportamento numa frase ou num enunciado;

4. saber as suas propriedades semânticas, o seu significado referencial, suas extensões metafóricas, seus valores afetivos, e a sua adequação pragmática;

5. saber as suas relações paradigmáticas com outras palavras, nomeadamente, com eventuais sinônimos, antônimos e hipônimos; e

6. saber as suas relações sintagmáticas, ou seja, as suas mais frequentes combinatórias. (grifo nosso)

O conhecimento prosódico das palavras é fundamental na aprendizagem de língua, pois, na conversação, a distinção de traços fonéticos e fonológicos, como em sábia (qualidade de alguém), sabiá (ave) e sabia (ato de saber), incide no entendimento do discurso, mesmo no aspecto conceitual, na organização do enunciado, na distribuição da palavra de acordo com as categorias gramaticais.

O conhecimento morfológico compõe o conjunto de informações que se situam no léxico, que são necessárias à aprendizagem. É da morfologia que se estruturam os processos de formação das palavras de acordo com as regras da língua. Portanto, aprender a estrutura das palavras auxilia o aprendiz a reconhecer as partes do discurso. Notemos ainda que o léxico, como componente básico do discurso, não pode prescindir da sintaxe, porque é esta que organiza o enunciado frásico.

O significado de uma palavra distribui-se na relação com outras palavras no discurso, o que permite que sejam reconhecidos os contrastes lexicais e gramaticais. É na interface entre léxico e gramática que a língua funciona, num processo contínuo de interação, uma vez que léxico e gramática são fenômenos socioculturais. Em vista disso, aprender uma língua exige mecanismo específico da parte do aprendiz. Por esse motivo, os materiais pedagógicos devem estar sensíveis a essa exigência. 


\subsection{O aprendiz de $L 2$ e de $L E$}

A aprendizagem de língua é um processo contínuo que se distingue da aquisição de língua, segundo o nível de conscientização do usuário, conforme distinção proposta por Krashen (1982, p. 10):

The first way is language acquisition a process similar, if not identical, to the way children develop ability in their first language. Language acquisition is a subconscious process; language acquirers are not usually aware of the fact that they are acquiring language, but are only aware of the fact that they are using the language for communication. [...] the term 'learning' henceforth to refer to conscious knowledge of a second language, knowing the rules, being aware of them, and being able to talk about them. In non-technical terms, learning is 'knowing about' a language, known to most people as 'grammar', or 'rules' .

Desse modo, podemos constatar que aprender uma língua é adquirir conhecimento das regras linguísticas e pragmáticas da língua-alvo de modo consciente, por meio de estudo formal e informal com apoio de recursos e de materiais didáticos. Língua é concebida como “instrumento de interação social e não existe, em si e por si, como uma estrutura arbitrária de alguma espécie, mas existe em virtude de seu uso para o propósito de interação entre os seres humanos" (NEVES, 1997, p.43). Assim, na aprendizagem, é preciso observar também os fatores cognitivos, os atos comunicativos e os interacionais, as mudanças e as variações linguísticas para que o aprendiz aprenda a língua-alvo e obtenha sucesso no uso em uma comunidade de fala.

Atualmente, o número de pessoas que querem ou precisam aprender outra língua diferente da sua L1 tem aumentado, seja por motivos profissionais, seja por motivos culturais, seja por motivos pessoais. No Brasil, por exemplo, há um incentivo do Ministério de Educação para a aprendizagem de línguas, conforme podemos constatar nos Parâmetros Curriculares Nacionais:

\footnotetext{
${ }^{4}$ Primeiramente, a aquisição de língua é um processo semelhante, se não idêntico, à forma como as crianças desenvolvem a capacidade em sua L1. Aquisição é um processo subconsciente; adquirentes de língua não são geralmente conscientes do fato de que eles estão a adquirindo, mas são apenas cientes do fato de que eles estão usando a língua para a comunicação [...] o termo 'aprendizagem' refere-se ao conhecimento consciente de uma L2, conhecer suas regras, sendo consciente delas, e ser capaz de falar sobre elas. Em termos não-técnicos, a aprendizagem é ‘conhecer' uma língua, conhecida pela maioria das pessoas como 'gramática', ou 'regras'.
} 
A aprendizagem de uma língua estrangeira, juntamente com a língua materna, é um direito de todo cidadão, conforme expresso na Lei de Diretrizes e Bases e na Declaração Universal dos Direitos Linguísticos, publicada pelo Centro Internacional Escarré para Minorias Étnicas e Nações (Ciemen) e pelo PEN-Club Internacional. Sendo assim, a escola não pode mais se omitir em relação a essa aprendizagem (BRASIL, MEC/SEF, 1998, p.19).

Entende o documento que ter conhecimento de uma língua "estrangeira é uma possibilidade de aumentar a autopercepção do aluno como ser humano e como cidadão" (BRASIL, MEC/SEF, 1998, p. 15). Pela mesma razão, os estrangeiros que vêm residir no Brasil e que aprendem a língua portuguesa como segunda língua obtêm conhecimento linguístico, cultural e social do país, o que aumenta a autopercepção deles como seres humanos. Grannier (2001, p. 2) adverte que, para a aprendizagem de uma língua estrangeira:

na maioria dos casos, o contato com a língua a ser aprendida só acontece em sala de aula, com limitações de tempo, de oportunidades de estar em situações naturais de uso da língua, de oportunidades de conhecer outros usuários da língua (além de seu professor) e de ter contato com a cultura do país onde se usa a língua.

Porém, no caso do estrangeiro residente no Brasil que aprende a língua portuguesa, a situação é a de estar imerso na língua do país e não só de estar limitado à sala de aula, mas de ter oportunidades de estar em situação natural de uso de língua, de conhecer vários falantes nativos do português e de ter contato com a cultura brasileira. Nesse caso, portanto, a aprendizagem se dá em uma perspectiva de segunda língua (doravante - L2) e não de língua estrangeira (doravante - LE), porque o aprendiz está vivendo a cultura local.

A dicotomia língua estrangeira (LE) e segunda língua (SL ou L2) envolve raciocínios consensuais:

In contrasting 'second' and 'foreign' language there is today consensus that a necessary distinction is to be made between a non-native language learnt and used within one country to which the term 'second language' has been applied, and a non-native language learnt and used with reference to a speech community outside national or territorial boundaries to which the term 'foreign language' is commonly given. A 'second language' usually has oficial status or a recognized function within a country which a foreign language has not (STERN, 1983, p. 16). ${ }^{5}$

\footnotetext{
${ }^{5}$ Contrastando-se os termos SL e LE, há, hoje em dia, consenso de que é necessário fazer distinção entre a aprendizagem de língua não nativa, em que o termo segunda língua é aplicado para classificar a aprendizagem
} 
Assim sendo, por um lado, a imersão ou a não-imersão, que considera o aspecto da localização geográfica do aprendiz, é um dos critérios utilizados para distinguir LE da L2. Por outro lado, outras diferenças associadas a elementos sociais, psicológicos e políticos devem ser consideradas.

A L2 é a língua oficial ou uma das línguas oficiais reconhecidas do país, é a língua do conhecimento utilizada nas escolas, e, por isso, é necessária para a participação plena na vida social e econômica do aprendiz (PAULSTON, 1974, e MARCKWARDT, 1963, apud STERN,1983, p. 16). A LE é aprendida com propósito diferente da L2, por exemplo, para ler literatura estrangeira, estabelecer comunicação com estrangeiros, fazer viagens de negócios ou de turismo.

O aprendiz de LE, normalmente, situa-se no espaço restrito da sala de aula, orientado por um professor, que conhece a língua-alvo. Por outro lado, o aprendiz de L2 situa-se em ambiente de imersão, no país da língua de aprendizagem, aprende a língua-alvo em sala de aula, orientado por um professor do território, falante nativo da língua de aprendizagem. Além disso, a aprendizagem pode dar-se em ambiente informal em que haverá a atuação dos falantes naturais que compartilham conhecimentos linguísticos. Por ser a língua oficial do país, há disponível input com características de outras variantes nacionais e regionais da mesma língua que refletirão no discurso do falante não-nativo, de acordo com Leiria (2004, p. 1). Como resultado disso, o aprendiz conhecerá a variante padrão e as variantes socioculturais.

Vale observar, no entanto, que há casos de estrangeiros que, mesmo vivendo em imersão no Brasil, não se tornam aprendizes de L2, pois não convivem naturalmente com os nativos e não necessitam, de modo efetivo, da língua oficial do país para exercerem suas funções sociais, políticas e econômicas. Nesse caso, a língua portuguesa é usada mais como LE do que como L2. Servem de ilustração os diplomatas que, por suas funções, vivem como se estivessem em seus países, comunicando-se, na maioria das vezes, apenas com o corpo diplomático estrangeiro, e, por isso, não necessitam da língua portuguesa, mesmo residindo no Brasil.

Para facilitar o reconhecimento das características que adotamos para distinguir L2 de LE, nesta pesquisa, com base nos estudos feitos e nas práticas sociais que envolvem

e o uso da língua não-nativa dentro das fronteiras nacionais ou territoriais para qual essa SL tem status oficial ou função reconhecida; enquanto o termo LE deve ser usado para classificar a aprendizagem e o uso dentro de um país onde a língua estrangeira não tem status oficial nem função reconhecida. 
língua, no que ocorre no Brasil, e em nossa experiência de docente da língua portuguesa como L2, apresentamos a figura a seguir.

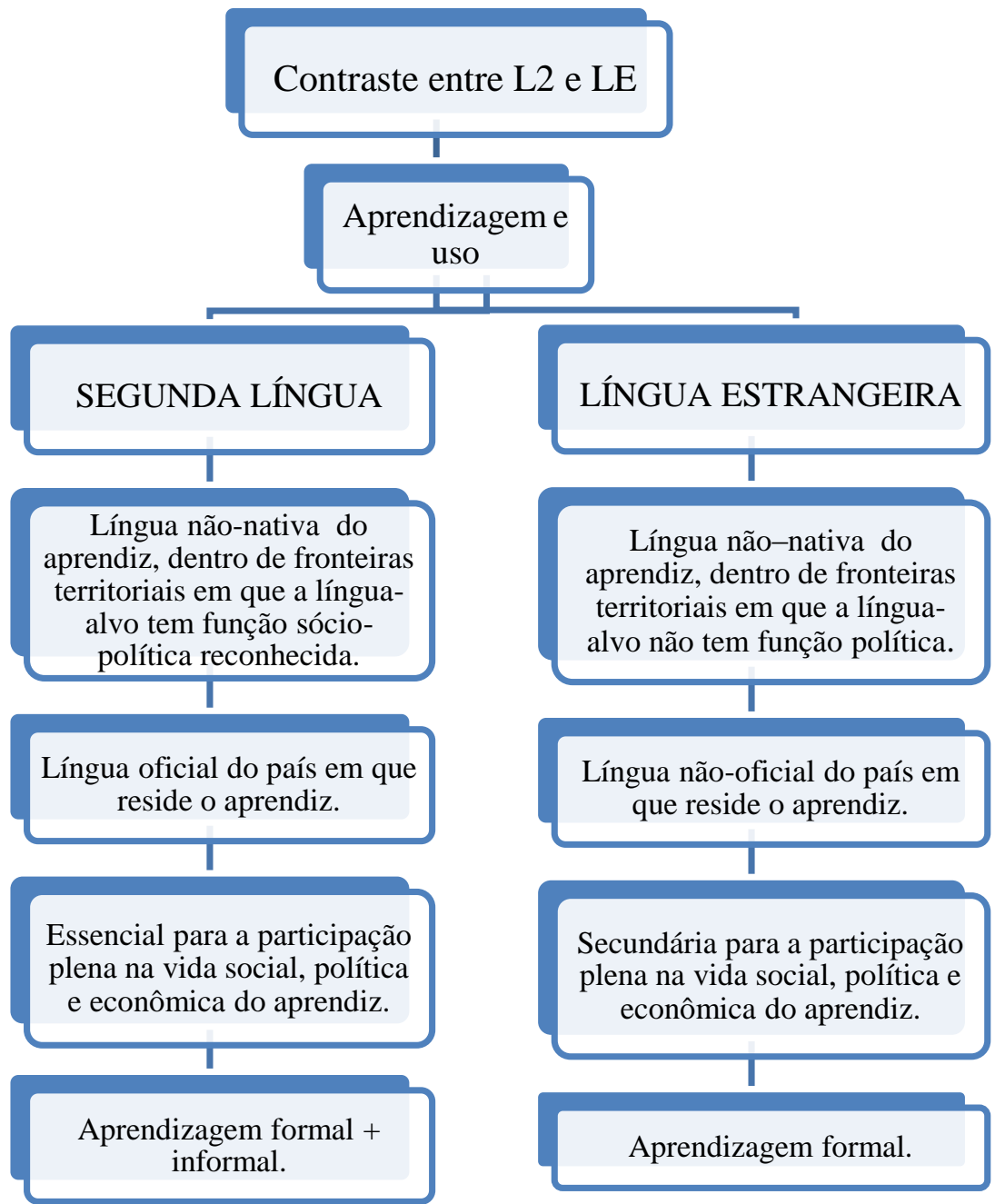

Figura 2: Contraste entre L2 e LE

Fonte: MAIA-PIRES, 2015.

Com vistas a situar nosso objeto de estudo, esclarecemos que, ao longo desta pesquisa, adotamos o conceito de segunda língua (L2) como: a) a língua não-nativa do aprendiz, que se encontra dentro das fronteiras territoriais em que a língua de aprendizagem é língua oficial do país; b) a língua que tem função social e política reconhecida dentro e fora do país; c) língua que é essencial para a participação plena na vida social, política e econômica do aprendiz; e d) a língua que é aprendida em ambiente formal e em ambiente 
informal. Por sua vez, adotamos o conceito de língua estrangeira (LE) como: i) língua nãonativa do aprendiz que se encontra dentro de fronteiras territoriais em que a língua em aprendizagem não é língua oficial; ii) não é a língua oficial do país em que reside o aprendiz; iii) a língua de caráter secundário para a participação plena na vida social, política e econômica; e iv) é aprendida em ambiente formal.

Assim, por estar no país, o aprendiz de L2 necessita de conhecer a língua, uma vez que terá contato direto com vários membros da comunidade de fala que nem sempre usam a variante de prestígio. Esse aspecto deve também ser considerado na elaboração de materiais didáticos para esse público.

\subsection{A propósito da natureza do léxico}

Como dissemos anteriormente, léxico e gramática são complementares, à medida que o vocabulário não lista só "palavras" da língua, mas fornece diferentes tipos de informações linguísticas combinadas, como as fonológicas, as ortográficas, as morfológicas, as sintáticas, assim como estruturas discursivas argumentativas, em decorrência da história social, cultural e política dos povos. O produto do significado discursivo abarca tanto o significado lexical quanto o gramatical, que incidem sobre as habilidades interacionais. As práticas interacionais dependem de funções desempenhadas pela gramática no léxico.

Para Mioto (2005, p. 119), “é impossível falar uma língua sem dominar o seu léxico, isto é, o conjunto de palavras que constitui o dicionário da língua em questão”. Para Basílio (2006, p. 9):

a língua é, ao mesmo tempo, um sistema de classificação e um sistema de comunicação e, neste caso, o léxico está diretamente ligado a essa dupla função que atua como uma espécie de banco de dados previamente classificado, um depósito de elementos de designação, que fornece unidades básicas para a construção dos enunciados.

Mais que isso: as palavras da língua têm propriedades tais que o aparecimento de certo item lexical já nos faz esperar outro item ou grupo de itens, formando uma rede associativa de palavras e significados aplicados ao discurso. Leiria (2001, p. 34) também não omite a importância do léxico na língua ao destacar Chomsky (1965), quando cita "o léxico como componente cada vez mais abrangente de propriedades e funções”. E Lara (1996, p. 96) afirma que "o diálogo que se produz entre os interlocutores explica, mostra ou 
exemplifica uma experiência, um acontecimento presenciado em conjunto", em que o léxico se faz presente.

Cabré (1993, p. 87) registra que "uma palavra é uma unidade descrita por um conjunto de características linguísticas sistemáticas e dotada de propriedade de referências a um elemento da realidade". Faulstich (1997) observa o conjunto e considera que o "léxico é uma unidade linguística dotada de características sistemáticas e que têm a propriedade de se referirem a entidades da realidade". Além disso, "as propriedades gramaticais são fortemente determinadas ou motivadas pelas propriedades léxico-conceptuais", como registra Rio-Torto (2006, p. 1) e segundo essa autora:

Em função da sua natureza, que é pluridimensional, o léxico - e, por conseguinte, o seu estudo -, não se confina a abordagens monodimensionais, envolvendo antes a morfologia das unidades lexicais que o integram, a semântica e a sintaxe interna e externa destas, o funcionamento discursivo-pragmático que os falantes delas fazem (RIOTORTO, 2006, p. 2).

Essas citações a respeito do léxico demonstram que o saber lexical faz parte dos fundamentos do conhecimento linguístico. Destacamos também que o léxico está sujeito a ampliações e restrições, que configuram o caráter aberto e apresentam as mudanças semânticas e fonológicas, por meio das intervenções dos usuários em suas interações sociais. O dinamismo da língua e o caráter aberto do léxico exigem do usuário constantes atualizações lexicais para manter o discurso ativo no contexto em que é empregado. $\mathrm{O}$ falante, por diversos motivos, cria e adapta novos itens lexicais no uso da língua, o que torna difícil o domínio total do léxico. Por isso, os dicionários, obras de referência de língua, são materiais úteis para o aprendiz que os consulta para sanar dúvidas linguísticas e, para os aprendizes mais experientes, que procuram também esclarecimentos extralinguísticos. Desse modo, o léxico, objeto de 'propriedade léxico-conceitual', é visto como documento de destaque no ensino e na aprendizagem de línguas.

McCarthy (1990, p. 8) enfatiza que "não importa o quanto o aluno aprenda a gramática, não importa o quanto domine os sons da L2, sem o léxico para expressar a vasta gama de significados, as comunicações em L2 não acontecem de forma significativa". O conhecimento lexical, ao lado do conhecimento gramatical, dá acesso à intercomunicação 
dos usuários da língua, pois é pelo uso apropriado das palavras que compreendemos e somos compreendidos.

Diante da importância do léxico na aprendizagem de língua e da complexidade do assunto, é necessário analisar como englobar a base lexical no processo de aprendizagem de L2, por meio de material lexicográfico, uma vez que "gramática" e "léxico" são sistemas abstratos de língua e, por isso, nos lemas (entradas) dos dicionários estão registradas abstrações que ganham vida no discurso.

\section{4. Os Dicionários e a aprendizagem de línguas}

Atualmente, em decorrência das alterações nos sistemas políticos e sociais dos povos, os dicionários sofreram adaptações de base científica e tecnológica e assumiram outros objetivos, como os pedagógicos para a aprendizagem de L1, L2 e LE. As informações lexicográficas, agora mais refinadas, contribuem para a ampliação do conhecimento de língua com a finalidade de auxiliar o aprendiz a compreender e a produzir textos de qualidade, para isso, devem apresentar interação vocabular, gramatical e conceitual apropriados ao contexto linguístico e ao contexto situacional em que o discurso ocorre. $\mathrm{O}$ dicionário é apresentado como uma obra que vai além da consulta de significados e de ortografia das palavras; é visto como uma fonte a mais de informações sobre língua, disponível ao aprendiz, que o utiliza para fazer consultas rápidas, pontuais e, por isso, essas informações devem ser de fácil acesso.

Em decorrência, há o aumento de pesquisas e de publicações que incentivam o uso das obras lexicográficas por parte de professores e de aprendizes de línguas, contemplando o ensino e a aprendizagem de L1, de L2 e de LE, independentemente de os aprendizes estarem inseridos em ambiente formal ou informal, porque, independentemente do ambiente, a consulta ao dicionário, em algum momento, é fato imprescindível. Isso se justifica em virtude da natureza do léxico, que, sempre em expansão, é processual e exige aprendizagem atualizada.

O dicionário, constituído em seu cerne pelos aspectos lexicais e gramaticais, "funciona como obra auxiliar à tarefa da leitura, porém é um tipo textual que requer muito mais do que decodificação; requer aprendizado, experiência, intimidade e destreza" (GOMES, 2007, p. 15). Esses valores decorrem de que "nos dicionários encontramos informação linguística, informação enciclopédica, científica”, conforme Correia (2009, 
p.15), entre outras informações. Além disso, de acordo com Faulstich (2010a, p.173) "pela própria natureza, um dicionário é um instrumento normatizador, já que, no corpo lexicográfico, há sempre uma grande preocupação como o 'bom uso' da língua; nesses termos, um dicionário é um complemento da gramática". Por último, acreditamos, como Tarp (2008, p. 51), que a obra lexicográfica presta serviços em duas direções:

Indirectamente al facilitar conocimientos sobre su vocabulario y gramática en relación con un estudio intencional de la lengua en cuestión, y directamente al facilitar informaciones que pueden aprovecharse para resolver problemas específicos durante el mismo proceso de comunicación, es decir en relación con la recepción y producción de textos $^{6}$.

Na figura seguinte, interpretamos a utilização do dicionário na aprendizagem de língua:

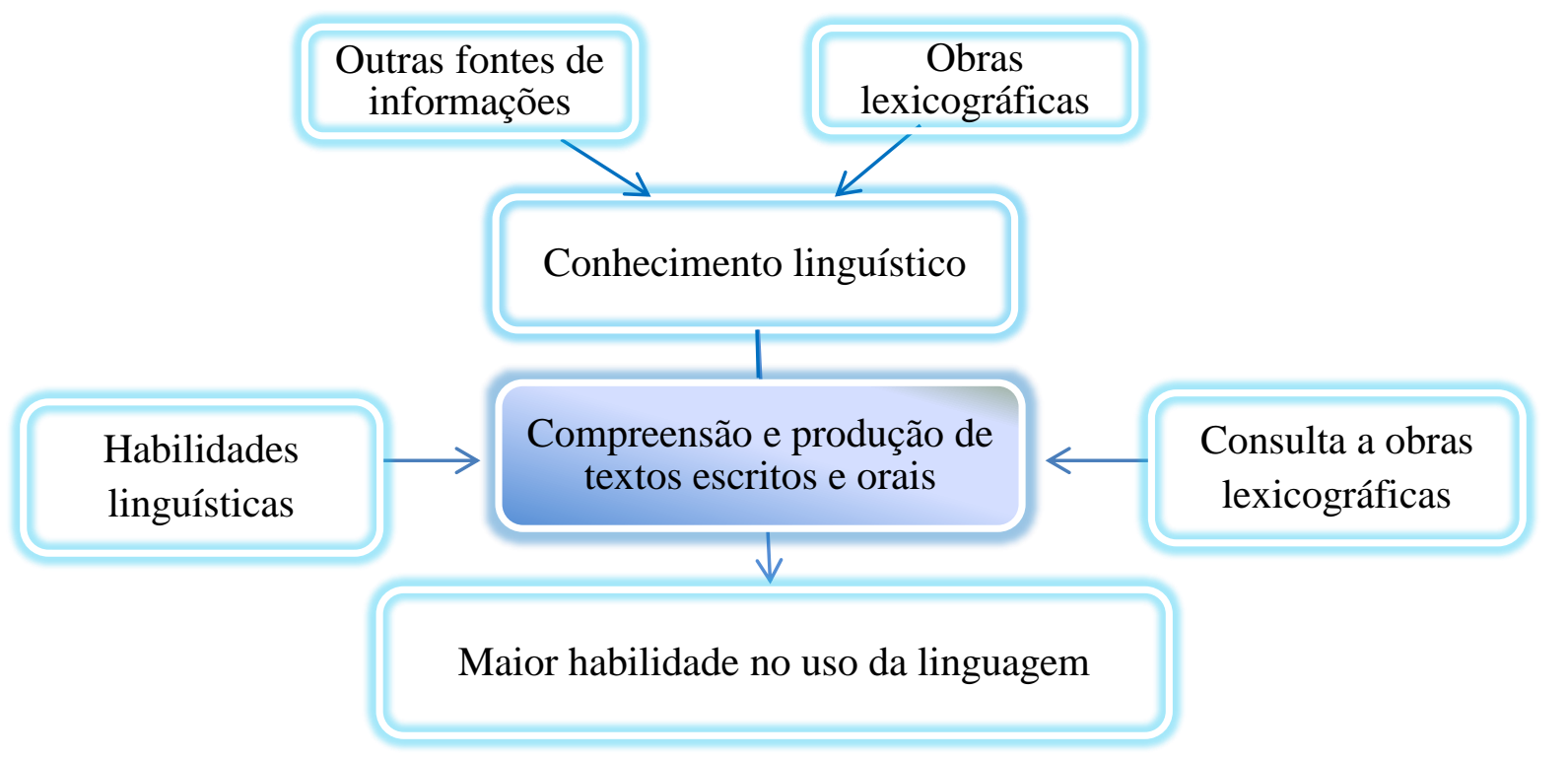

Figura 3: Processo de aprendizagem de língua

MAIA-PIRES, 2015 (Adaptado de TARP, 2008, p. 51)

Vemos nesse gráfico que o papel do dicionário é mais amplo do que demonstrar habilidades específicas de compreensão e de produção textual, fornece meios para capacitar

\footnotetext{
${ }^{6}$ Indiretamente, ao facilitar conhecimentos sobre o vocabulário e a gramática (de uma língua) relacionados ao estudo intencional da língua em aprendizagem, e diretamente para fornecer informações que podem ser usadas para resolver problemas específicos durante o próprio processo de comunicação, ou seja, em relação à compreensão e à produção de textos.
} 
o aprendiz para o uso da língua no processo de aprendizagem. É material didático para ser consultado a qualquer tempo, a fim de atender às necessidades do aprendiz.

Autor de dicionários, Borba (2003, p. 301) nos ajuda a acrescentar que:

\begin{abstract}
A gramática e o dicionário são instrumentos pedagógicos de primeira linha; têm pontos em comum, mas não se superpõem. Diga-se, primeiramente, que o dicionário é o lugar particular, do tópico, e a gramática é do genérico, das regras. O dicionário enumera palavras, a gramática enumera conjunto de regras que, aplicadas, mostram como a língua funciona. A gramática apresenta, de forma sistemática, um conjunto de regras de combinatória dos constituintes da língua, em seus diversos níveis. Assim, em princípio, não compete à gramática dizer como se usa uma palavra, já que ela não se ocupa de palavras isoladas, mas de conjuntos ou classes de entidades que compõem o sistema linguístico. Isso quer dizer que a gramática não comportaria arrolamentos, nem mesmo das chamadas palavras gramaticais. Não comporta. O lugar dos arrolamentos é o dicionário. Por exemplo, a gramática não arrola os usos de cada um dos possessivos meu, teu, seu etc., mas os define como classe ou subclasse, indica suas funções, suas posições nos sintagmas nominais etc. Já o dicionário arrola os usos de cada um deles. A gramática estabelece critérios para o agrupamento das palavras em classe a partir de traços em comum sejam eles funcionais ou semânticos. $\mathrm{O}$ dicionário não discute, toma decisões e pode rotular cada palavra como pertencente a uma classe. A gramática enuncia uma regra que se aplica uma subclasse, o dicionário mostra a aplicação da regra palavra por palavra, verbatim.
\end{abstract}

Visto dessa forma, reconhecemos que o dicionário desempenha papel pedagógico na aprendizagem de língua diferente da gramática. Esta fornece informações genéricas sobre as regras da língua, aquele, por sua vez, fornece informações específicas das palavras contidas no corpo lexicográfico, assegurando, desse modo, a compreensão semântica, útil na ação comunicativa concreta, ajustada ao pensamento de aprendizes e usuários. E o avanço tecnológico colabora para esse recurso pedagógico, pois os dicionários devem possibilitar consulta rápida por meio de softwares ou aplicativos disponíveis em celulares, tablets, ipads, notebooks, ultrabooks etc.

Os dicionários com fins pedagógicos, de modo geral, são obras elaboradas desde a concepção para um público que se encontra em aprendizagem de língua, seja L1, seja L2, seja LE. Esse tipo de dicionário, com fins pedagógicos, não é exclusivo dos tempos atuais, pois já havia dicionários bilíngues para aprender o latim no século XVI, como o Vocabulario portuguez \& Latino. 
Entretanto, a história da lexicografia revela que, com a constituição dos novos Estados, principalmente no que se refere à língua portuguesa, no período do Renascimento, os dicionários tiveram como finalidade legitimar a língua oficializada pelo Estado. Os elaboradores dos dicionários da língua dos novos Estados estavam preocupados em registrar o máximo de informações que considerassem relevantes para a descrição das línguas nacionais. As informações não eram organizadas de modo pedagógico, o que dificultava a aprendizagem. Como herança dessa época, destacam-se os tesauros, que possuem mais de 100.000 entradas, contendo, em alguns casos, informações muito extensas, cheias de abreviaturas e símbolos.

A intensificação do mercado financeiro mundial com a união de países com fins político-econômicos provocou o desenvolvimento de métodos e técnicas para o ensino e a aprendizagem de línguas e, como consequência, o fazer lexicográfico foi repensado. Assim surge a Lexicografia Pedagógica.

Duran (2008, p. 84) afirma que "o florescimento da Lexicografia Pedagógica é fruto do conhecimento mais aprofundado sobre os aprendizes e suas dificuldades, aliado, é claro, à evolução da tecnologia e dos próprios conhecimentos linguísticos”. Os dicionários que seguem essa concepção são os infantis, os escolares e os para aprendizagem.

Os dicionários infantis, entre outras finalidades, visam auxiliar as crianças na aprendizagem do sistema alfabético, da forma das palavras, dos significados das unidades lexicais mais frequentes no universo infantil. Esses dicionários, normalmente, apresentam fontes grandes, coloridas e são elaborados com estratégias que motivem o interesse da criança em consultar a obra. Segundo o Ministério da Educação (2012, p. 22), esse tipo de dicionário deve conter número de entradas limitado, verbete de estrutura simples, pequeno número de acepções, explicações do sentido das palavras, ilustrações e linguagem acessível ao público-alvo, como Meu primeiro livro de palavras: um dicionário ilustrado do português de A a Z, de Biderman (2011).

Os dicionários escolares, que visam ao aprofundamento e ao aperfeiçoamento do domínio da língua dos aprendizes de L1 em fase de escolarização, são de uso no ensino fundamental. Caracterizam-se por apresentar o vocabulário utilizado nos livros escolares, abrangendo todas as classes gramaticais, verbetes de estrutura mais complexa, ilustrações funcionais e uso de linguagem impessoal, às vezes mais especializada ou técnica, conforme Ministério da Educação (2012, p. 32). O dicionário Aurélio Junior: dicionário escolar da língua portuguesa, de Ferreira (2011), encontra-se nesta classificação. 
Os dicionários para aprendizagem são as obras direcionadas ao público que deseja aprender uma língua estrangeira ou uma segunda língua e podem ser monolíngues ou não. Esses dicionários são organizados para facilitar a compreensão e a produção da LE ou da L2. Apresentam instruções para o uso do dicionário, vocabulário controlado, indicação de pronúncia, exemplos de uso contextualizado, informações gramaticais, ilustrações funcionais, mas não apresentam informações etimológicas nem palavras consideradas arcaicas, por julgar desnecessário para o uso atual da língua.

Os dicionários para aprendizagem são organizados para facilitar a aprendizagem. Para atender esse propósito, considera-se o tamanho da fonte, a distribuição dos componentes estruturais, o tipo de definição, a origem dos exemplos de uso, entre outros, que satisfaçam as necessidades do perfil do público-alvo. Desse modo, o aprendiz obterá conhecimentos semânticos, gramaticais, pragmáticos e culturais da língua em aprendizagem para compreender e produzir enunciados que exprimam o pensamento. Como exemplos desse tipo de obra, citamos Cambridge Learner's Dictionaty (2004), que é monolíngue, e Password: English dictionary for speakers of Portuguese (2010), que é semibílingue. Não temos conhecimento, até o momento, de dicionários elaborados com fins pedagógicos para aprendizes do português do Brasil, seja como LE ou L2.

Ao verificarmos essa lacuna, escolhemos elaborar um dicionário de aprendizagem. Para isso, selecionamos informações sobre os verbos da língua portuguesa, comuns ao cotidiano dos brasileiros, e as organizamos de modo sistemático para fornecer os significados desses verbos em contexto de uso real, exemplificados em textos de jornais, revistas e filmes. A utilização do contexto de uso tem por finalidade delimitar o significado para facilitar a compreensão do verbo, o que pode proporcionar também a produção de enunciados coerentes por parte do aprendiz. Além disso, o aprendiz de PSL terá acesso à pronúncia dos verbos, à morfologia verbal, de acordo com as conjugações, e aos tipos de complementos que acompanham o verbo, segundo o significado utilizado nos contextos que são abordados no dicionário.

\subsubsection{Dicionários bilíngues e dicionários semibilíngues}

Os dicionários bilíngues, tradicionalmente, são os que descrevem uma determinada língua e mantêm a correlação da unidade linguística em outra língua, por exemplo, português-inglês/inglês-português. Para cada entrada da língua-fonte, há uma ou mais 
unidades linguísticas correspondente na língua-alvo, caso não haja uma unidade linguística correspondente, há uma perífrase para expressar o conceito descrito pela língua-fonte.

Ilustramos com verbetes do dicionário bilíngue Michaelis: dicionário prático inglêsportuguês, 2. Ed. (2010):

\author{
Inglês-Português \\ dine [dain] $v t+v i \mathbf{1}$ jantar. they dined off on cabbage soup as there was nothing else I \\ eles jantaram sopa de repolho já que não havia outra coisa. 2 dar jantar a. to dine out jantar \\ fora de casa. \\ din.ner [d' inə] $n \mathbf{1}$ jantar $\mathbf{2}$ banquete $\mathbf{3}$ ceia

\section{Português-Inglês} \\ jan.tar [3ãt'ar] sm dinner, eveningmeal, o jantar está na mesa / dinner is serverd $\cdot$ vint to \\ dine. hora do jantar dinner time. jantar fora to dine out. sala de jantar dining room.
}

Os dicionários semibilíngues são produtos com características do dicionário monolíngue para aprendizes e com características do dicionário bilíngue. A metalexicografia apresenta-se apenas em uma das línguas, contendo a entrada, a categoria gramatical, a definição ou paráfrase, o exemplo de uso e a unidade linguística correspondente na outra língua abordada pelo dicionário, normalmente da LE ou da L2 > L1. Os dicionários semibilíngues no Brasil são de elaboração reduzida, comparada à quantidade de dicionários bilíngues. Normalmente, são obras adaptadas, como o Señas: diccionario para la enseñanza de la lengua española para brasileños, o Password: English dictionary for speakers of Portuguese, Palavra-chave: dicionário semibilíngue para brasileiros: francês, publicados pela editora Martins Fontes.

Exemplificamos verbetes do dicionário semibilíngue Password: English dictionary for speakers of Portuguese (2010), da editora Martins Fontes.

\author{
Inglês-Português \\ dine [dain] verb to have dinner: We shall dine at half-past eight. $\square$ jantar \\ dine noun 1 a peson who dines: The diners ran from the restourant when the fire started. \\ comensal \\ 2 a restaurant car on a train. $\square$ vagão-restaurante \\ dining-room noun a table roud which people sit to eat $\square$ mesa de jantar \\ dine on to have for one's dinner: They dined on lobster and champagne. $\square$ jantar \\ dine out to have dinner somewhrere other than one's own hause eg in a restaurant ot at \\ the hause og friends etc. $\square$ jantar fora
}

Glossário Português-Inglês

Jantar dine, dine on, dinner, supper 
Para os dicionários bilíngues, Duran e Xatara (2007, p. 312-313) descrevem três critérios que são utilizados para classificá-los:

FUNCIONALIDADE: existem duas funções básicas do dicionário bilíngue - apoio à codificação e apoio à decodificação. A função de codificar está associada à direção língua materna $\rightarrow$ língua estrangeira; e a função de decodificar está associada à direção língua estrangeira $\rightarrow$ língua materna.

RECIPROCIDADE: critério que diz respeito ao público-alvo do dicionário bilíngue. O dicionário bilíngue recíproco é aquele que tem dois públicosalvo: tanto os falantes da língua-fonte quanto os falantes da língua-alvo. Nele, cada uma das direções do dicionário pretende atender duas funções: enquanto um público utiliza as informações para decodificar, o outro as utiliza para codificar. O dicionário não- recíproco, ao contrário, é aquele que se destina a falantes de apenas uma das línguas nele contempladas.

DIRECIONALIDADE: critério que admite duas ocorrências. Sendo, por exemplo, A e $\mathrm{B}$ as línguas envolvidas, o dicionário bilíngue monodirecional é aquele que apresenta apenas uma das direções possíveis, ou $\mathrm{AB}$ ou $\mathrm{BA}$, enquanto o bidirecional apresenta ambas as direções, $\mathrm{AB}$ e BA.

Os dicionários bilíngues consideram a posição da L1 e a posição da LE ou a da L2 e, em vista disso, podem ser bidirecionais. Apresentam como ponto de partida a LE ou a L2, língua-fonte, e como ponto de chegada a L1, língua-alvo (LE ou L2 $\rightarrow$ L1); na contrapartida, há inversão de direção, a L1 passa ser a língua-fonte e a LE ou a L2 passa ser a língua-alvo $(\mathrm{L} 1 \rightarrow \mathrm{LE}$ ou L2).

Quanto à reciprocidade, os dicionários bilíngues são classificados como recíprocos quando a metalinguagem utilizada para descrever a língua-fonte também é utilizada para descrever a língua-alvo. Assim, o dicionário recíproco pode servir aos falantes da línguafonte e aos da língua-alvo em igualdade, de modo que não favorece apenas um deles.

No caso dos dicionários semibilíngues, não há reciprocidade quanto à metalinguagem que descreve a língua-fonte e a língua-alvo, pois a metalinguagem apresentase apenas na língua em aprendizagem. No entanto, há um índice remissivo L1 > LE ou L2, em que ocorre o registro do item lexical da L1 e o correspondente na língua em aprendizagem (LE ou L2). Assim, o dicionário semibilíngue é monodirecional, privilegiando um único público. A presença da L1 do consulente varia de acordo com o grau de conhecimento da língua em aprendizagem: para os aprendizes de nível básico, há maior presença, para os de nível intermediário ou avançado, a presença da L1 é menor. 
1.4.2. Dicionários e público-alvo: o aprendiz de L2

Embora o dicionário seja um importante recurso para a aprendizagem, nem sempre as demandas dos consulentes são atendidas, uma vez que cada público tem interesses distintos, segundo o testemunho de usuários diversos, descritos em Xatara, Bevilacqua e Humblé (2011, p. $155-161)$ :

a) $\quad \mathrm{Na}$ condição de tradutor para a língua alemã desde 1982, os dicionários fazem parte do meu dia a dia [...]. De um apoio voltado à solução de problemas pontuais do léxico, e sempre numa perspectiva bilíngue, aos poucos os dicionários passaram a me trazer respostas para questões mais abrangentes ligadas à dimensão pragmática da linguagem: a pesquisa de diferentes domínios de uso, questões de convencionalidade, formas indiretas de expressões, entre outras.

b) Utilizo o dicionário bilíngue e o dicionário monolíngue inglês para esclarecer dúvidas e fazer pesquisa. O dicionário é um grande aliado que tenho, pois ele me permite encontrar palavras desconhecidas, verificar pronúncias, diferentes entradas para a mesma palavra, preposições necessárias, questões culturais, expressões idiomáticas.

c) As dúvidas que mais me motivam a procurar os dicionários dizem respeito à escrita correta das palavras e também a seus significados, conforme o jeito com que são empregadas e também conforme o contexto geral.

Nesses relatos, distintos usuários buscam dicionários com discurso compatível com o perfil do consulente. Serve de exemplo o que nos diz Faulstich (2010a, p. 174) no excerto seguinte, a propósito de uma lexicografia especializada:

O dicionário infantil é projetado e elaborado para a faixa etária a que ele pretende atingir e é editado com tipo de letras grandes e em cores. $\mathrm{O}$ discurso apresenta-se próximo da oralidade, induzindo o usuário a pensar que está dialogando com o autor do dicionário [...]. Um dicionário escolar compõe-se de entradas que, em sua grande parte, contemplam itens lexicais inclusos nos programas de ensino dos currículos escolares, com vistas à transdisciplinaridade, afinal é um dicionário que completará a compreensão dos significados que circundam os conhecimentos ministrados na escola. $\mathrm{O}$ dicionário fundamental abrange um léxico útil para a aquisição de vocabulário e descreve um universo de palavras que está na esfera de interesse da faixa etária para a qual foi concebido (FAULSTICH, 2010a, p. 174).

Como vemos, o público-alvo é responsável por atribuir características fundamentais ao dicionário, justificando a variedade das obras lexicográficas. Todavia, é preciso observar 
também que, pelas características linguísticas e extralinguísticas, a língua possui uma memória social, por isso, na elaboração de um dicionário, convém observar que a língua envolve orientações além das regras gramaticais, cabendo aos lexicógrafos equilibrar as informações que podem ser de interesse dos consulentes.

Haensch (1982, p.397) afirma que, embora, entre os lexicólogos e lexicógrafos exista consenso de que "por lo que se refiere a los usuarios, hay que determinar de antemano a quién se dirige el diccinario, glosario, etc., lo cual influirá también en la relación entre el aspecto puramente lingüístico y el enciclopédico ${ }^{7 \%,}$, na prática, são encontradas obras elaboradas para o ensino da língua sem público-alvo determinado, o que causa problemas de aprendizagem.

Para fundamentar questões relativas a esses equívocos, apresentamos, no capítulo 4, aspectos da estrutura de dicionários bilíngues e semibilíngue, para identificar os elementos de composição de dicionários e, assim, compreender as divergências e convergências dessas obras para o ensino e a aprendizagem de línguas.

\subsubsection{A necessidade de dicionários para aprendizes de PSL}

Por causa da projeção econômica do Brasil, há atualmente um aumento considerável de estrangeiros que querem aprender o Português do Brasil. Servem de ilustração as relações entre Sudão e Brasil, que estão desenvolvendo projetos na área da Agroindústria; as relações entre Ucrânia e Brasil, que estão desenvolvendo projetos na área de indústria aeroespacial e, ainda, as relações entre China e Brasil, pois, como se sabe, o "Gigante Asiático" tornou-se um dos maiores parceiros comerciais do nosso país. Os casos citados resultam de nossa experiência como docente da língua portuguesa como L2 aos estrangeiros residentes em Brasília. Além desses, o Ministério do Turismo tem projetos para o setor, como uma atividade econômica sustentável, o que também se reflete no aumento de turistas estrangeiros no país e no interesse em aprender a língua portuguesa. Acrescentam-se ainda os eventos esportivos internacionais, como a Copa do Mundo de 2014 e as Olimpíadas de 2016, que, realizados no Brasil, têm atraído investidores estrangeiros que vêm residir no país e precisam aprender o português para o desempenho de suas atividades comerciais.

\footnotetext{
${ }^{7}$ Por se referirem aos usuários de língua, há a necessidade de determinar desde o início a quem se destinará o dicionário, glossário etc., uma vez que isso influenciará também nas relações entre o aspecto puramente linguístico e o enciclopédico.
} 
Na prática docente e nas atividades de pesquisa, verificamos ausência de dicionários para os aprendizes de PSL e de PLE. Observamos que, devido à carência de materiais lexicográficos para esse público, alguns aprendizes chegam a elaborar seus próprios materiais, como, por exemplo, o Glossário Vietnamita-Português, elaborado por um diplomata da embaixada do Vietnã. É possível que esses materiais não obedeçam a critérios linguísticos, lexicológicos e lexicográficos e que possam conter informações equivocadas. Outro recurso utilizado por esses aprendizes é o uso de obras disponíveis no mercado, mas que não foram concebidas para o fim desejado.

Em vista disso, para que o léxico do Português do Brasil esteja bem sistematizado, há necessidade de maior desenvolvimento da Lexicografia, que pode ser aperfeiçoada por meio da aplicação das teorias linguísticas e dos recursos tecnológicos inovadores para a elaboração de dicionários. E essa tecnologia deve realmente ser nova, pois Duran e Xatara (2007, p. 210) constataram que, “embora os dicionários eletrônicos tenham se tornado comuns, na maioria das vezes, ainda, imitam o leiaute dos dicionários impressos".

Para preencher esta lacuna, acreditamos no desenvolvimento de estudos e de pesquisas que elevem o léxico corretamente nos dicionários de aprendizes de PSL, uma vez que o contexto atual, no qual o Brasil está inserido, não permite a existência dessa lacuna. Nossa intenção, nesta pesquisa, é elaborar uma proposta de modelo de dicionário de verbos do português do Brasil como L2 informatizado que atenda às demandas da sociedade moderna e à aprendizagem de língua mediante as necessidades do público-alvo. 


\subsection{Síntese do capítulo}

Neste capítulo, expusemos o percurso dos dicionários como material pedagógico para o ensino de PSL e apresentamos algumas teorias sobre a natureza do léxico e seus atributos para aprendizagem de língua. Destacamos a relevância do público-alvo na elaboração de dicionários e procuramos chamar a atenção para os problemas decorrentes da falta de dicionários para estudantes de PSL. Em vista disso, concluímos que há urgência em elaborar dicionários para públicos específicos, aprendizes de PSL, que contemplem a diversidade brasileira, por meio da língua portuguesa falada no Brasil, em decorrência do contexto político, econômico e social. 


\section{CAPÍTULO 2 - O CONTEXTO COMO AGENTE CONTRIBUIDOR PARA A SIGNIFICAÇÃO}

Durante o processo de aprendizagem de uma língua, percebemos que a avaliação de parte do que foi aprendido ocorre nas interações comunicativas, por meio das quais são identificados ou enunciados bem construídos, ou enunciados que precisam de reformulações, ou enunciados descontextualizados. O conhecimento linguístico é testado em casos reais, que exigem a participação do aprendiz, ora como produtor, ora como destinatário do enunciado. Essa percepção respalda-se na concepção de que a "language is in the first place conceptualized as an instrument of social interaction among human beings, used with the intention of establishing communicative relationships" (DIK, 1997, p. 3$)^{8}$. Desse modo, a aprendizagem de língua visa ao propósito de suprir uma das necessidades dos seres humanos: relacionar-se com o mundo. Destacamos que, na interação, enunciados são construídos para transmitir as intenções comunicativas do falante, que ocorrem dentro de contextos específicos. Isso acontece porque a produção e o entendimento de enunciados não ocorrem em um vazio, quer dizer, os enunciados são produzidos em contextos comunicativos.

Nesse sentido, nossa pesquisa adota os estudos teóricos relacionados à teoria da Gramática Discursivo-Funcional, porque, como Connolly (2007, p. 11) enfatiza: “An important and admirable characteristic of the FDG framework is that it takes very seriously the fact that utterances are produced and understood is context ${ }^{9}$ ". Assim, o presente capítulo apresenta o embasamento teórico de nossa pesquia.

\subsection{A Gramática Discursivo-Funcional}

A inclusão dos aspectos pragmáticos nos estudos de língua propulsionou novas teorias linguísticas. Destacamos a Gramática Discursivo-Funcional - FDG - de Hengeveld e Mackenzie (2008), concebida por meio de avanços e de aplicações de pesquisas na linha da Gramática Funcional - GF- de Dik (1978 e 1997).

\footnotetext{
${ }^{8}$ Língua, em primeiro lugar, é concebida como um instrumento de interação social entre seres humanos, usada com o objetivo primordial de estabelecer relações comunicativas.

${ }^{9}$ uma característica importante e admirável da Gramática Discursivo-Funcional - GDF - é a de que considera seriamente o fato de enunciados serem produzidos e entendidos em contexto.
} 
A Gramática Funcional de Dik considera a interação verbal, pois afirma que a função representativa da linguagem se integra na função interpessoal e social. Interação verbal, segundo Dik (1997, p. 8), é representada do seguinte modo:

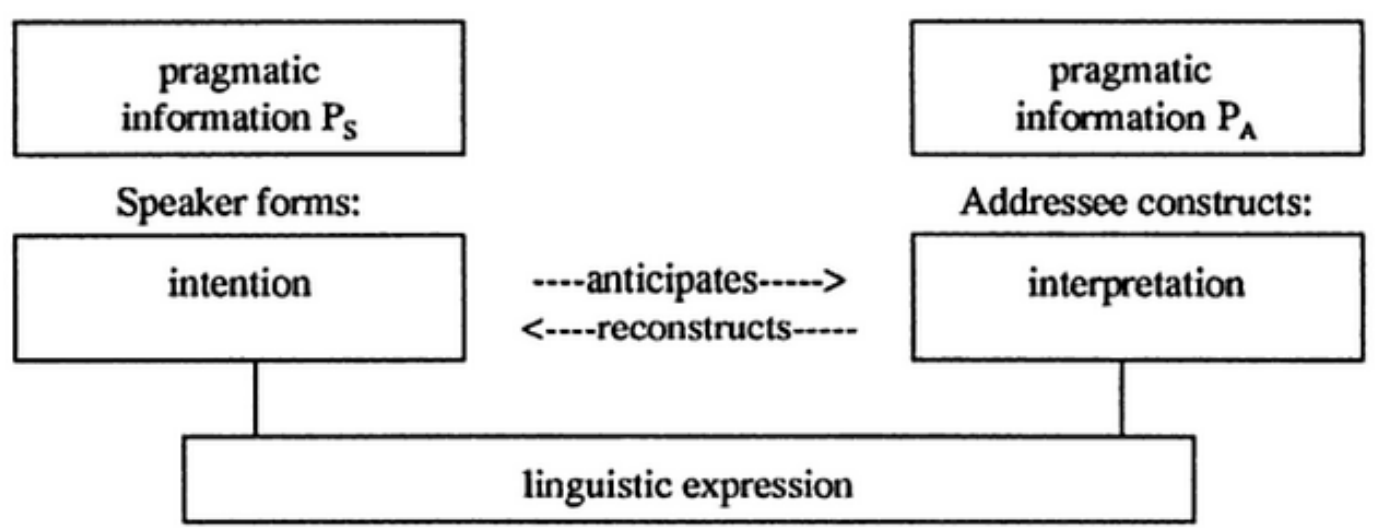

Figura 4: Modelo de interação verbal

Fonte: (DIK, 1997, p. 8)

O esquema acima representa o fato de que, na interação verbal, os participantes envolvidos possuem informações pragmáticas - por parte do falante (Speaker's Pragmatic Information - $\mathrm{P}_{\mathrm{S}}$ ) e do destinatário (Addressee's Pragmatic Information - $\mathrm{P}_{\mathrm{A}}$ ) - suficientes para estabelecerem uma comunicação. Assim, ao dizer algo para o destinatário (que o autor representa por A - addressee), a intenção do falante (que o autor representa por S -speaker) é provocar modificação na $\left(\mathrm{P}_{\mathrm{A}}\right)$ do destinatário. E para alcançar seu objetivo, o falante formula uma intenção comunicativa, em nível mental, relacionada à modificação que ele deseja efetuar em $\left(\mathrm{P}_{\mathrm{A}}\right)$. Para isso, o falante antecipa a interpretação que seu destinatário pode atribuir à sua expressão linguística, dado o estado de $\left(\mathrm{P}_{\mathrm{A}}\right)$ no momento. Essa antecipação por parte do falante exige que ele selecione as informações relevantes de $\left(\mathrm{P}_{\mathrm{A}}\right)$. Por outro lado, o destinatário interpreta a expressão linguística do falante em função de $\left(\mathrm{P}_{\mathrm{A}}\right)$ e da sua estimativa de $\left(\mathrm{P}_{\mathrm{S}}\right)$, e, assim, ocorre a reconstrução da intenção comunicativa presumida pelo falante. A interpretação chegada ao destinatário pode afetar modificações em $\left(\mathrm{P}_{\mathrm{A}}\right)$, correspondendo, assim, à intenção comunicativa do falante. Se a interpretação do destinatário não for a desejada pelo falante, há um mal-entendido. Porém, alguns malentendidos passam despercebidos no dia a dia, mas aqueles que impedem o prosseguimento da comunicação são corrigidos, por meio de negociação entre os participantes que trocam de papéis, falante-destinatário, em turnos distintos. 
Em vista disso, depreende-se que, além das expressões linguísticas, há outros elementos envolvidos no processo comunicativo, o que gera necessidade de abarcar as questões pragmáticas nas análises linguísticas, porque exercem influência na produção e na interpretação comunicativas. Existem fenômenos linguísticos que são analisados mais adequadamente se considerarmos o gênero discursivo, o contexto, os participantes dos eventos comunicativos, o que prestigia a interação verbal.

A interação verbal também é incorporada no modelo da Gramática DiscursivoFuncional de Hengeveld e Mackenzie (2008). Porém, esses autores ampliam a teoria, ao incluir o componente conceitual, o componente contextual e o componente de saída ao componente gramatical.

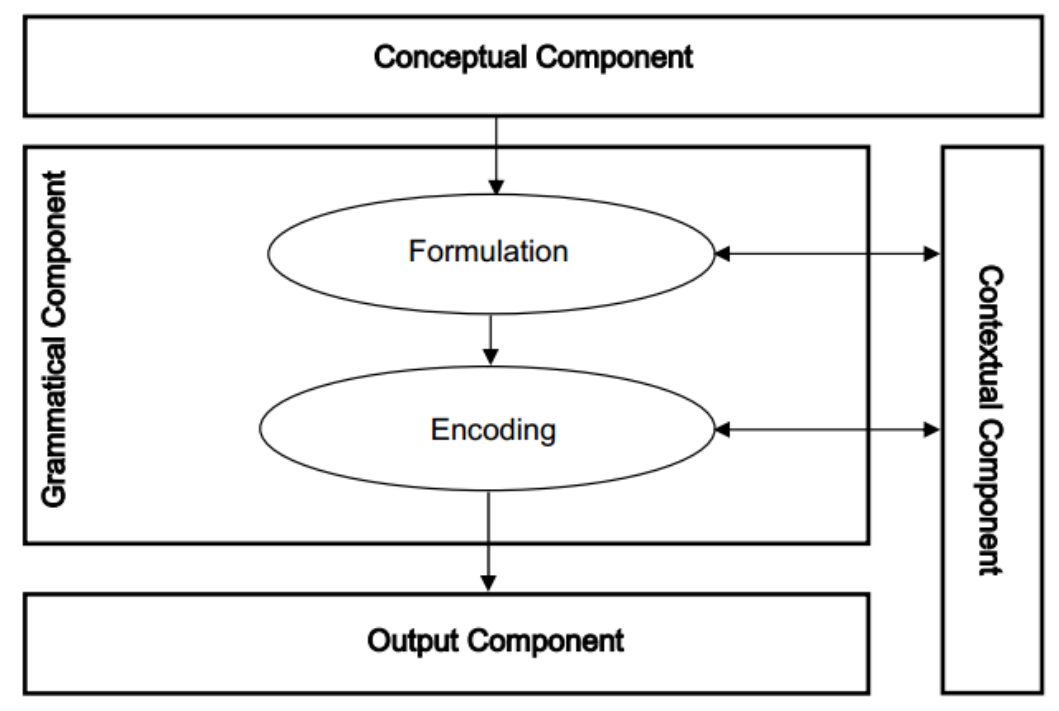

Figura 5: A GDF como parte de uma teoria mais ampla da interação verbal Fonte: (HENGEVELD \& MACKENZIE, 2010, p. 2)

Hengeveld e Mackenzie (2010) destacam, por meio dessa figura, que "FDG is conceived of as the Grammatical Component of an overall model of verbal interaction in which it is linked to a Conceptual Component, an Output Component and a Contextual Component ${ }^{10 "}$. Desse modo, o modelo apresenta componentes não gramaticais, que são o componente conceitual, o componente de saída e o componente contextual, como elementos que interagem com o componente gramatical, por meio de operações de formulação e de

\footnotetext{
${ }^{10}$ A Gramática Discursivo-Funcional é concebida como o Componente gramatical de um modelo global de interação verbal que está ligado a um componente conceitual, um componente de saída e um Componente Contextual. To appear in: Heine, Bernd \& Narrog, Heiko eds, The Oxford Hand book of Linguistic Analysis. Oxford: Oxford University Press, 2010.
} 
codificação, de várias formas. Entretanto, o modelo pressupõe que essa interação ocorre em organização hierárquica, de cima para baixo (top-down), apresentada pelas setas verticais. Os autores denominam de formulação as possíveis especificações pragmáticas e semânticas na língua e de codificação as regras que convertem essas representações pragmáticas e semânticas em morfossintática e fonológica.

A arquitetura geral do modelo é apresentada na figura posterior, em relação aos componentes não-gramaticais, como descrevemos a seguir:

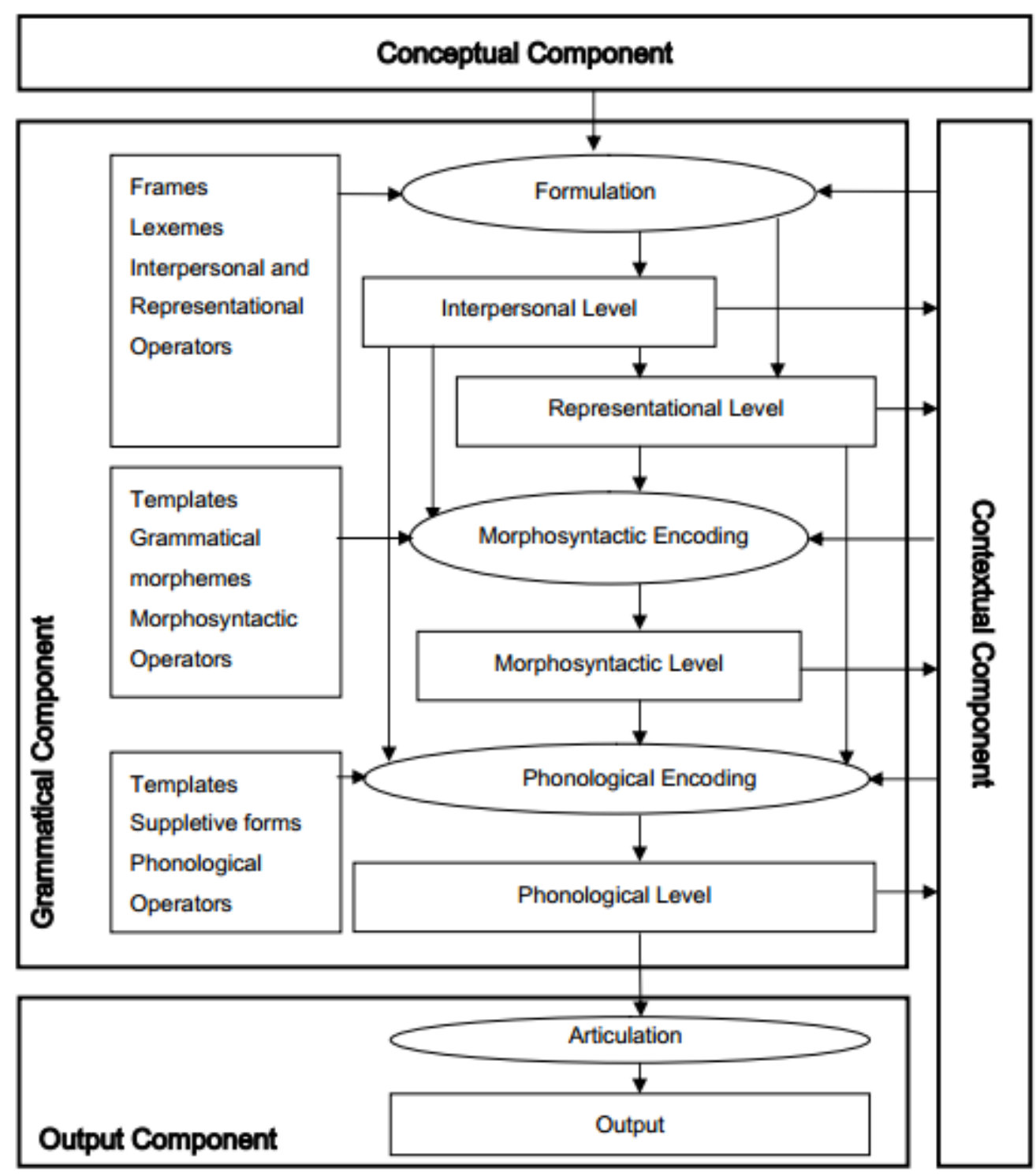

Figura 6: Arquitetura geral da GDF

Fonte: (HENGEVELD \& MAKENZIE, 2010 p. 4) 
Hengeveld e Makenzie (2010, p. 5) argumentam que o objetivo principal da Gramática Discursivo-Funcional "is to give an account of morphosyntactically and phonologically codified phenomena in languages, either as correlated with pragmatic or semantic aspects of Formulation or as displaying inherent properties of Encoding ${ }^{11}$ ". Assim, associa-se o modelo ao parâmetro funcionalista que considera que uma grande parte das categorias formais são explicadas quando se analisa a gramática relacionada à pragmática, à semântica, em meio à cognição humana e à interação social.

A arquitetura da GDF é composta pelo componente gramatical que existe nas línguas, central no modelo, o qual contém as regras que regem a codificação, processo pelo qual as representações semânticas e as representações pragmáticas são convertidas em representações morfológicas e fonológicas. Há três componentes que se somam ao componente gramatical, que são o componente de saída, o componente conceitual e o componente contextual, que ligam o mundo exterior e o cognitivo do indivíduo à gramática da língua.

O componente conceitual, segundo Hengeveld e Mackenzie (2008; 2010), concebido como pré-linguístico, é responsável pelo desenvolvimento da intenção comunicativa e do evento de fala, associando-se ao aspecto cognitivo e ao conteúdo extralinguístico envolvidos no evento comunicativo. Desse modo, o componente conceitual é a força que impulsiona o processo de formulação, em que o conhecimento de longa duração, denominado long term knowledge, o conhecimento de mundo, a intenção comunicativa e a competência linguística são englobados. Conforme descrevem os autores da GDF, esse componente é responsável pela operação de formulação, que representa a conversão de representações pré-linguísticas conceituais em representações pragmáticas e semânticas, o que é permitido pelas regras da língua. Em vista disso, somente as informações pragmáticas e semânticas consideradas relevantes para o evento comunicativo são fundamentais no processo de formulação. No caso dos verbos, informações sobre a representação dos eventos como ação, estado, processo ou estado-processo seriam relevantes nas operações de formulação.

O componente contextual é concebido como o componente que contém a descrição do conteúdo e da forma do discurso precedente, por isso é relevante para processos gramaticais, pois contém informações como pessoa do discurso, tempo, modo,

\footnotetext{
${ }^{11}$ é dar conta dos fenômenos morfossintáticos e fonológicos codificados nas línguas, seja como correlatos de aspectos pragmáticos e semânticos, seja como portadores de propriedades inerentes da codificação .
} 
encadeamento narrativo, mediante a percepção real do que ocorre no evento comunicativo. Em vista disso, a percepção real da situação em que o evento ocorre interage com o nível conceitual, fixando determinadas categorias. No caso dos verbos, esse componente fornece informações relevantes sobre o número de participantes, pessoa do discurso, tempo, modo.

O componente de saída é responsável por gerar as expressões acústicas, escritas ou sinalizadas (incluindo as línguas de sinais), com base nas informações fornecidas pelo componente gramatical.

Entre esses componentes, os componentes conceitual e contextual estão conectados com o interesse desta tese, em vista de identificarmos que esses componentes, na estrutura do modelo topdown e na dinamicidade da GDF, podem nos auxiliar na concepção do modelo de dicionário de aprendizagem. Entendemos que, neste modelo, a produção de enunciados vai da intenção para a articulação, influenciados pelos fatores pragmáticos, contextuais e interacionais, evidenciando a necessidade de incluir esses componentes em obras lexicográficas. Isso porque, com vistas ao caráter pedagógico do dicionário, a organização da microestrutura de dicionário de aprendizagem deve apresentar os significados articulados aos aspectos pragmáticos, semânticos e gramaticais em que ocorrem os eventos discursivos. Desse modo, deve-se observar o contexto cultural, que contém informações de caráter mais abrangente, situando o enunciado num complexo cultural e ideológico; o contexto situacional, que contém informações extralinguísticas referentes às condições de produção do enunciado; e o contexto linguístico, que contém informações linguísticas que auxiliam no contexto do enunciado. Esses três contextos organizam-se com propósito comunicativo.

Apresentaremos, assim, detalhamentos dos níveis interpessoal e representacional, representados pelos retângulos na figura 6, dentro do componente gramatical, por estarem fortemente relacionados aos componentes conceitual e contextual.

\subsubsection{Nível interpessoal e nível representacional}

Existem, no modelo da GDF, quatro níveis de organização linguística, hierarquicamente ordenados em camadas, que descrevem as funções e os significados dos elementos linguísticos codificados na gramática de uma língua. São o nível interpessoal, o nível representacional, o nível morfológico e o nível fonológico. Esses níveis traduzem as representações conceituais em representações semânticas e pragmáticas, por meio das operações de formulações. 
O nível interpessoal está relacionado aos aspectos formais de uma unidade linguística, refletindo o papel da unidade na interação entre os participantes do ato discursivo. É o nível das estratégias empregadas para se conseguir os objetivos comunicativos. Esses aspectos englobam as noções retóricas de toda a estruturação do discurso com a finalidade de representar os conceitos extralinguísticos em forma linguística. Hengeveld e Mackenzie (2008, p. 47) estruturam as relações hierárquicas no nível interpessoal com as seguintes variáveis:

\begin{tabular}{|c|c|c|}
\hline \multicolumn{2}{|l|}{$\left(\pi M_{1}:[\right.$} & Move \\
\hline \multirow[t]{8}{*}{$\left(\pi A_{1}:\right.$} & [ & Discourse Act \\
\hline & $\left(\pi F_{1}: \operatorname{ILL}\left(F_{1}\right): \Sigma\left(F_{1}\right)\right)$ & Illocution \\
\hline & $\left(\pi P_{1}: \ldots\left(P_{1}\right): \Sigma\left(P_{1}\right)\right)_{s}$ & Speaker \\
\hline & $\left(\pi P_{2}: \ldots\left(P_{2}\right): \Sigma\left(P_{2}\right)\right)_{A}$ & Addressee \\
\hline & $\left(\pi C_{1}: \quad[\right.$ & Communicated Content \\
\hline & $\left(\pi T_{1}:[\ldots]\left(T_{1}\right): \Sigma\left(T_{1}\right)\right)_{\Phi}$ & Ascriptive Subact \\
\hline & $\left(\pi R_{1}:[\ldots]\left(R_{1}\right): \Sigma\left(R_{1}\right)\right)_{\Phi}$ & Referential Subact \\
\hline & ] $\left.\left(\mathrm{C}_{1}\right): \Sigma\left(\mathrm{C}_{1}\right)\right)_{\Phi}$ & Communicated Content \\
\hline \multicolumn{2}{|c|}{]$\left.\left(A_{1}\right): \Sigma\left(A_{1}\right)\right)_{\Phi}$} & Discourse Act \\
\hline \multicolumn{2}{|l|}{ ] $\left.\left(M_{1}\right): \Sigma\left(M_{1}\right)\right)$} & Move \\
\hline
\end{tabular}

Figura 7: Nível interpessoal

Fonte: (HENGEVELD \& MACKENZIE, 2008, p. 49)

Em que:

$\mathrm{M} \longrightarrow$ Movimento (Move): unidade autônoma de interação relevante para a análise discursiva; expressa uma intenção comunicativa do falante, por exemplo, motivar.

$\mathrm{A} \longrightarrow$ Ato discursivo (Discourse atc): unidade mínima do comportamento comunicativo, por exemplo, correspondente a uma oração declarativa no M 'motivar'.

ILL $\longrightarrow$ Ilocução (Illocution): ilocução codificada na expressão, por exemplo, tipo de oração declarativa, é codificada em frames ilocucionários abstratos que determinam traços prosódicos, morfológicos entre outros.

$\mathrm{P}_{\mathrm{S}}$ e $\mathrm{P}_{\mathrm{A}} \longrightarrow$ Participantes falantes e destinatários $(P$ - Participante, $P$-Speaker, $P$ Addressee): os participantes envolvidos na ilocução.

$\mathrm{C} \longrightarrow$ Conteúdo comunicado (Communicated Content): conteúdo semântico comunicado envolvendo o ato e o modo da informação a ser comunicada, contém a totalidade do que o falante deseja evocar em sua interação com o destinatário. 
$\mathrm{T} \longrightarrow$ Subato de atribuição (Ascriptive Subact): subato em que ocorre a construção do conteúdo por predicação, é a tentativa do falante de evocar uma propriedade.

$\mathrm{R} \longrightarrow$ Subato referencial (Referential Subact): subato em que o falante registra propriedades para entidades por meio de expressões referenciais, é a tentativa do falante de evocar um referente.

$\Pi \longrightarrow$ Operador (Operator): mecanismo que representa estratégias gramaticais, aplica-se à própria unidade.

$\Phi \longrightarrow$ Função (Function): mecanismo que representa estratégias gramaticais, que atua entre uma unidade inteira e outras unidades da mesma camada.

$\Sigma \longrightarrow$ Modificador (Modifier): mecanismo que representa a estratégia lexical.

Essas variáveis são intercaladas por símbolos convencionados pela GDF com papéis distintos, em que dois pontos (:) representa que cada variável predica argumentos; colchetes [ ] representam a delimitação das camadas do nível interpessoal; e parênteses ( ) representam a inserção das variáveis no nível interpessoal. Para exemplificar, reproduzimos o exemplo dado por Hengeveld e Mackenzie (2008, p. 49), envolvendo um conteúdo comunicado e uma ilocução lexical.

(1) Honestamente, eu não gosto de você.

- $\quad\left(\mathrm{M}_{\mathrm{I}}:\left[\left(\mathrm{A}_{\mathrm{I}}:\left[\left(\mathrm{F}_{\mathrm{I}}: \mathrm{DECL}\left(\mathrm{F}_{\mathrm{I}}\right):-\right.\right.\right.\right.\right.$ honestamente- $\left.\left(\mathrm{F}_{\mathrm{I}}\right)\right)\left(\mathrm{P}_{\mathrm{I}}\right)_{\mathrm{S}}$

$\left(\mathrm{P}_{\mathrm{J}}\right)_{\mathrm{A}}\left(\mathrm{C}_{\mathrm{I}}\right.$ : - Eu não gosto de você $\left.\left.\left.\left.\left.-\left(\mathrm{C}_{\mathrm{i}}\right)\right)\right]\left(\mathrm{A}_{\mathrm{I}}\right)\right)\right]\left(\mathrm{M}_{\mathrm{I}}\right)\right)^{12}$

Como se observa, a intenção comunicativa do falante $\left(\mathrm{P}_{\mathrm{I}}\right)_{\mathrm{S}}$ em relação ao destinatário $\left(\mathrm{P}_{\mathrm{J}}\right)_{\mathrm{A}}$, declarar algo, é representada pelo ato discursivo $\left(\mathrm{A}_{\mathrm{I}}\right)$, modificado lexicalmente pela ilocução, honestamente, que introduz o conteúdo comunicado $\left(\mathrm{C}_{\mathrm{I}}\right)$, eu não gosto de você.

O nível representacional está relacionado ao processo da designação, exprime os aspectos semânticos, "is thus restricted to the ways in which language relates to the possible worlds it describes ${ }^{13}$ " (HENGEVELD e MACKENZIE, 2008, p. 46). Nesse nível, os lexemas são introduzidos como representações de categorias semânticas com conteúdo básico, sendo particular de cada língua. Assim como o nível interpessoal, o nível

\footnotetext{
${ }^{12}$ Exemplo do texto original: Honestly, I don't like you. $\left(\mathrm{M}_{\mathrm{I}}:\left[\left(\mathrm{A}_{\mathrm{I}}:\left[\left(\mathrm{F}_{\mathrm{I}}: \mathrm{DECL}\left(\mathrm{F}_{\mathrm{I}}\right):-\right.\right.\right.\right.\right.$ honestly $\left.-\left(\mathrm{F}_{\mathrm{I}}\right)\right)\left(\mathrm{P}_{\mathrm{I}}\right)_{\mathrm{S}}\left(\mathrm{P}_{\mathrm{J}}\right)_{\mathrm{A}}$ $\left(\mathrm{C}_{\mathrm{I}}\right.$ : - I don't like you - $\left.\left.\left.\left.\left.\left(\mathrm{C}_{\mathrm{i}}\right)\right)\right]\left(\mathrm{A}_{\mathrm{I}}\right)\right)\right]\left(\mathrm{M}_{\mathrm{I}}\right)\right)$ - Hengeveld e Mackenzie (2008, p. 46)

${ }^{13}$ Restrito aos meios pelos quais uma língua se relaciona com os mundos possíveis que esta descreve. Hengeveld e Mackenzie (2008, p. 46).
} 
representacional também é organizado em camadas hierárquicas, mantendo o padrão top down, em que o elemento mais alto do nível é o conteúdo proposicional (p), que, por sua vez, contém um ou mais episódios, que contém um ou mais estados de coisa, organizados em propriedade, indivíduo, lugar, tempo, modo, quantidade e razão. Estado de coisa é compreendido como algo que pode ocorrer no mundo real ou mundo imaginário. Nesse nível, as camadas relevantes são definidas segundo as categorias semânticas que designam. Estão estruturadas com as seguintes variáveis:

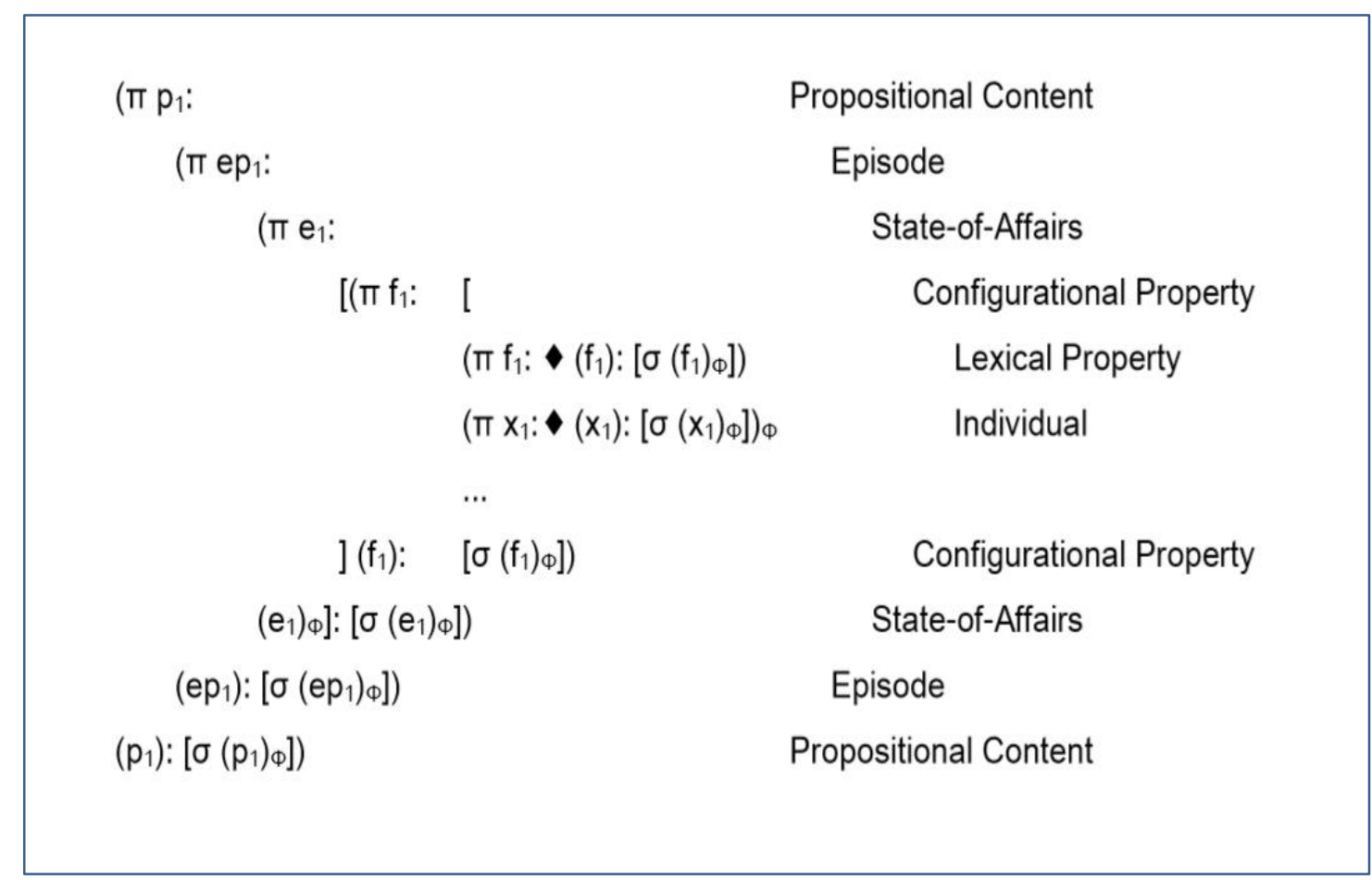

Figura 8: Nível representacional

Fonte: (HENGEVEL \& MACKENZIE 2008 p. 142)

Em que:

$\mathrm{p} \longrightarrow$ Conteúdo proposicional (Propositional Content): constructo mental que não pode ser localizado no tempo, nem no espaço, que pode ser factual, correspondente a conhecimentos ou crenças sobre o mundo real, ou não factual, correspondente a desejos ou expectativas em relação a um mundo imaginário;

ep $\longrightarrow$ Episódio (Episode): unidade semântica formada por um conjunto de proposições, quer dizer, conjunto de estados de coisa tematicamente coerente, que demonstram unidade ou continuidade de tempo (t), localização (l), e indivíduo (x); 
e $\longrightarrow$ Estado de coisa (State-of-Affairs): unidade que inclui eventos e estados, compreendido como algo que pode ocorrer no mundo real ou mundo imaginário, localizados em tempo relativo;

$\mathrm{f} \longrightarrow$ Propriedade configuracional (Configurational Property): inventário que não tem existência independente e só pode ser avaliada em termos de sua aplicabilidade a outros tipos de entidade, é construída usando categorias semânticas que estabelecem uma relação não hierárquica entre si, que pode ter tipologia variada, incluindo indivíduos (x); e

$\mathrm{x} \longrightarrow$ Indivíduo (Individual): entidade existente em um mundo real ou imaginário, que pode ser localizado em um espaço.

Exemplificamos essa estrutura organizacional com um enunciado retirado de um texto jornalístico sobre a estiagem que atingiu o Sistema Cantareira em São Paulo, em 2014, recolhido em nosso corpus:

(2) A estiagem secou a represa. (G1.globo)

$\left(\mathrm{e}_{\mathrm{i}}:\left[\left(\mathrm{f}_{\mathrm{i}}: \operatorname{secar}_{\mathrm{v}}\left(\mathrm{f}_{\mathrm{i}}\right):\left(\mathrm{x}_{\mathrm{i}}: \text { estiagem }_{\mathrm{N}}\left(\mathrm{x}_{\mathrm{i}}\right)\right)_{\mathrm{Ag}}\right)\left(\mathrm{x}_{\mathrm{j}}: \operatorname{represa}_{\mathrm{N}}\left(\mathrm{x}_{\mathrm{j}}\right)\right)_{\text {pac }}\right]\left(\mathrm{e}_{\mathrm{i}}\right)\right)$

A representação inclui os lexemas secar, estiagem e represa, em que ocorre uma combinação de categorias semânticas, entre colchetes, que fornece a descrição composicional de um estado de coisa $\left(\mathrm{e}_{\mathrm{i}}\right)$, incluindo os nomes que designam uma propriedade $\left(\mathrm{f}_{\mathrm{i}}\right)$, que fornecem a descrição lexical de dois indivíduos $\left(\mathrm{x}_{\mathrm{i}}\right)$ e $\left(\mathrm{x}_{\mathrm{j}}\right)$. As letras subscritas $i$ e $j$ são co-indexações para a aplicação da variável (f). Em vista disso, percebemos que o modelo prevê que o processo de formulação é formado a partir de um conjunto primitivo originado por meio de combinações de categorias semânticas que são organizadas em esquemas representacionais. Ainda quanto às variáveis que compõem a arquitetura da GDF, registramos que, além de (t) tempo e (l) lugar, o sistema inclui (m) modo, (r) razão e (q) quantidade, que podem se agregar ainda às variaveis (f) propriedade e (x) indivíduo.

Seguindo o sistema topdown, a GDF inclui a codificação morfossintática que representa a "conversão" da configuração dos níveis interpessoal e representacional, registrados no nível morfossintático. Assim sendo, o nível morfossintático processa os aspectos estruturais de uma unidade linguística, que, em conjunto com o nível fonológico, atua na codificação das distinções interpessoais e representacionais. Portanto, alguns fenômenos que ocorrem no nível morfológico são funcionalmente motivados. Por exemplo, 
no modelo da GDF, princípios de ordenação de constituintes são motivados por iconicidade; princípios de integridade de domínio, por preservação das relações de escopo. Destacamos que os autores da GDF registram que o modelo "does not make a distinction between a syntactic and a morphological level of analysis, as the principles used in the formation of words are the same as those used in the formation of phrases and clauses ${ }^{14 ",}$ (HENGEVELD e MACKENZIE, 2010, p. 17).

No nível morfossintático, o conjunto de primitivos usados na codificação morfossintática fornece os padrões estruturais, templates, morfemas gramaticais e operadores morfossintáticos apropriados, como se estrururam nesse nível. Do mesmo modo, no nível fonológico, as estruturas dos níveis interpessoal, representacional e morfossintático são codificadas em estrutura fonológica, mantendo a articulação entre os níveis. As regras de expressão apóiam-se em um conjunto de primitivos que contém sons, prosódia, morfemas presos e operadores fonológicos secundários, que alimentam o sistema para a produção de enunciados, seguindo o sistema hierárquico da GDF, segundo Hengeveld e Mackenzie (2010, p. 20).

Assim sendo, apresentamos princípios básicos da GDF que darão suporte ao próximo tópico, que tem por finalidade expor os aspectos contextuais dentro do componente contextual previsto pelo modelo, os quais fornecem elementos para o componente gramatical e, assim, ativam as regras que regem a codificação e a formulação dos enunciados, que são do interesse desta pesquisa.

\subsection{A inter-relação do contexto com a Gramática Discursivo-Funcional}

As informações contextuais são relevantes nas teorias funcionalistas. A GDF admite a importância do componente contextual na produção dos enunciados, pois "the Contextual Component contains a description of the content and form of the preceding discourse, of the actual perceivable setting in which the speech event takes place, and of the social relationships between Participants"15, de acordo com Hengeveld e Mackenzie (2008, p. 8). Para os autores do modelo, este componente contém dois tipos de informações: i) informação

\footnotetext{
${ }^{14}$ FDG não faz distinção entre o nível sintático e o nível morfológico de análise, uma vez que os princípios utilizados na formação de palavra são os mesmos utilizados na formação de frase e orações.

${ }^{15} \mathrm{O}$ componente contextual contém a descrição do conteúdo e da forma do discurso precedente do contexto real perceptível, em que ocorre o evento de fala, e das relações sociais entre os participantes.
} 
imediata (short-term information), recebida do componente gramatical concernente a um enunciado específico que é relevante para a forma dos enunciados subsequentes, e ii) informação de longo prazo (long-term information) sobre a interação em andamento, que é relevante para as distinções que são requisitadas pela língua em uso e que interferem na formulação e na codificação dessa língua (HENGEVELD e MACKENZIE, 2008, p. 9-10). Em vista disso, o componente contextual contém informações que influenciam o funcionamento do componente gramatical, porque apresenta aspectos que são considerados nas etapas de formulação e de codificação, como o gênero e o número dos participantes. Ilustramos isso com um exemplo da língua portuguesa:

(3) "Praias ficam cheias em domingo ensolarado no inverno carioca. A suíça, que atualmente mora com brasileiros no Catete, $\underline{\text { adiou } a ~ s u a ~ v o l t a ~ c o m ~ o ~ o b j e t i v o ~ d e ~}$ aprender português. Ela não esconde $a$ sua paixão pela praia de Ipanema e a elegeu como o seu programa favorito no Rio". (site o globo. Acesso em 12.08.14).

em que, na produção do enunciado (3), as informações quanto ao gênero, feminino, e ao número, singular, são relevantes. O componente contextual contribui com o componente gramatical na composição dos enunciados. Estabelece relações anafóricas como a relação e a ordem entre o pronome, ela, e seu referente, suíça, de acordo com os estudos de Cornish (2009), sobre anáfora discursiva, relacionados ao componente contextual da GDF. Além disso, as informações de número, pessoa, tempo e modo são relevantes para a representação verbal dos lexemas morar, adiar, esconder, eleger. Essas informações serão acessadas nas operações de formação e de codificação.

Os elementos extralinguísticos descritos pelos itens lexicais Ipanema, praia localizada no Rio de Janeiro; domingo, primeiro dia da semana, considerado dia de descanso e de lazer; dia ensolarado, dia típico para os cariocas irem à praia; associados ao fato de a suíça estar na praia dando entrevista, emitindo sua opinião sobre o dia ensolarado e a praia de Ipanema a um jornalista, também atuam nas operações de formulação e codificação em conjunto com os elementos já citados. Entretanto, como apontam Hengeveld e Mackenzie (2008, p. 9), a GDF não desenvolve o componente contextual de modo mais profundo. Porém, por ser um componente crucial na análise de língua, outros pesquisadores como Connolly (2007) e Cornish (2009) desenvolveram estudos sobre o componente contextual. 
Segundo Connolly (2007, p.13), uma explicação explícita da inter-relação entre língua e contexto de modo substancial é possível quando o contexto for abordado como nível de descrição, em que esse componente é definido como qualquer parte circundante a um discurso e é relevante para sua produção e interpretação. O autor destaca que é essencial restringir o que é relevante para o contexto, pois, se incluíssemos todas as partes circundantes, seria completamente difícil analisá-lo dentro de um modelo. E a avaliação do que é considerado relevante depende do analista, por isso contexto não é um fenômeno objetivo, e, sim, um constructo analítico. Assim sendo, Connolly (2007, p. 14), ao considerar que o contexto é dinâmico e que está em constante mudança, à medida que o discurso progride, propõe categorizações para o componente contextual. O pesquisador aponta para o fato de, no mundo contemporâneo, graças à tecnologia da informação, a multimídia ser onipresente, nos impede de ignorar a natureza multimodal do discurso. Em vista disso, Connolly (2007, p. 14) descreve as seguintes dicotomias:
a) Contexto discursivo $v s$ contexto situacional.
b) Contexto físico $v s$ contexto sociocultural.
c) Contexto restrito vs contexto amplo.
d) Contexto mental $v s$ contexto 'extra-mental'.

Contexto situacional corresponde à parte do contexto que está fora do discurso, pode ser dividido em 'contexto físico' e 'contexto sociocultural'. O contexto físico é fornecido pelo universo material, e inclui fatores como tempo e espaço. O contexto sociocultural, é fornecido pelo universo não-material, em que se incluem a organização social e as normas de pensamento e de comportamento da comunidade de fala. Ainda quanto à arquitetura do componente contextual, há uma subdivisão aplicada tanto ao contexto físico quanto ao contexto sociocultural, denominado de 'restrito' e 'amplo'. O contexto físico restrito pode ser chamado de 'cenário' (setting) e o contexto sociocultural restrito pode ser chamado de a 'cena' (scene), em que o autor emprega a terminologia de Hymes (1972, p. 60). Enfatizamos que em um mesmo ‘cenário' podem ocorrer diferentes 'cenas'. Para ilustração desses conceitos, apresentamos um exemplo da realidade brasileira em que a Esplanada dos Ministérios (cenário) ora pode ser palco para manifestações políticas, ora pode ser palco para festividades comemorativas (cenas), eventos socioculturais distintos no mesmo espaço. 
O contexto situacional amplo corresponde às informações fornecidas pelo universo físico e social fora do contexto imediato. O contexto sociocultural amplo corresponde às informações relacionadas à organização social de modo global e às normas de pensamento e de comportamento.

Reutilizaremos nosso exemplo (3) para ilustrar alguns destes conceitos: o contexto físico restrito é fornecido pela praia de Ipanema no dia da entrevista; o contexto sociocultural restrito corresponde aos papéis da suíça como entrevistada, aquela que fala, e o jornalista, aquele que é o destinatário interessado na opinião dela. Quanto ao contexto físico amplo, inclui Ipanema, praia localizada no Rio de Janeiro; domingo, primeiro dia da semana, e o contexto sociocultural amplo abarca domingo ensolarado, dia de descanso e de lazer, típico para ir à praia, segundo a cultura dos cariocas.

Contexto discursivo corresponde ao discurso multimodal circundante, incluindo os aspectos linguísticos e não-linguísticos. Assim, Connolly (2007) designa o termo 'contexto linguístico' como um subconjunto do contexto discursivo. O contexto discursivo contém subcategorias quanto ao aspecto restrito e amplo. O contexto discursivo restrito é equivalente ao '(co)texto', o contexto textual circundante ao fragmento discursivo a ser analisado ou entendido; e contexto discursivo amplo equivalente ao 'intertexto', referência ou alusões a outros textos. Quanto aos conceitos de texto, contexto e discurso, Cornish (2009) aponta algumas divergências ao reinterpretar a proposta de Connolly (2007) e ao contribuir para a arquitetura do componente contextual que destacaremos mais adiante.

Em relação aos conceitos sobre o contexto 'mental' e o contexto 'extra-mental', Connolly (2007, p. 18-19) descreve o primeiro como parte do contexto que reside na mente dos falantes e dos destinatários (incluindo analistas) de um discurso ou fragmento do discurso. Com referente ao segundo conceito, contexto 'extra-mental', o autor descreve-o como elemento fornecido pelo universo exterior e acrescenta que a subdivisão do contexto em partes 'mentais' e 'extra-mentais' dá nova dimensão para a estrutura hierárquica do contexto, uma vez que cada participante do evento comunicativo tem sua própria representação mental, ou ponto de vista sobre o contexto, por isso o contexto 'mental'. Desse modo, incluem-se todos esses pontos de vista, o que pode gerar uma sobreposição das diferentes perspectivas, e, portanto, de conhecimento compartilhado entre os diferentes participantes.

Em vista do que foi exposto até agora, observa-se que o contexto tem uma estrutura hierárquica que é multidimensional. Assim sendo, é possível identificar os níveis 
hierárquicos do componente contextual, considerando também os aspectos sobre gêneros discursivos, pois de acordo com o tipo discursivo há diferenças relevantes nos eventos comunicativos, segundo Connolly (2007, p. 18). Nesse sentido, apresentamos a arquitetura do componente contextual concebida por Connolly (2007) e delineada por Cornish (2009):

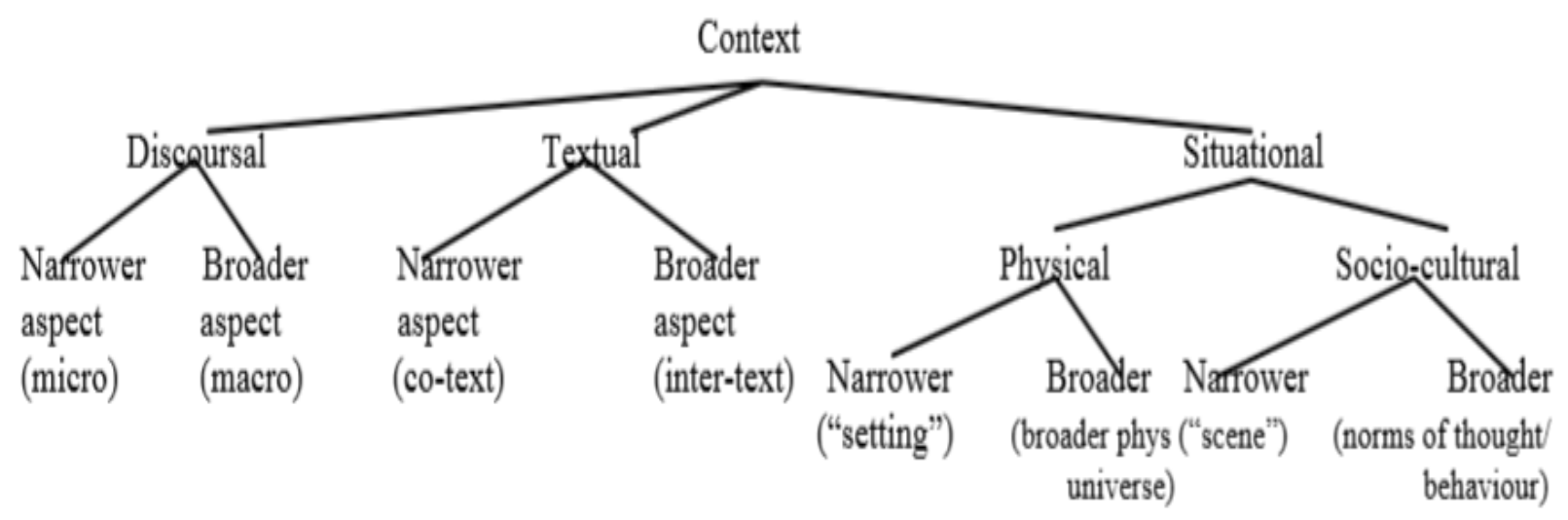

Figura 9: Representação esquemática, revisada por Cornish, da concepção de Connolly

Fonte: (CORNISH, 2009, p. 107)

Com base nessa estrutura, Cornish (2009, p. 107) destaca que as três grandes vertentes de "contexto" não estão no mesmo nível, atribuindo o contexto situacional à posição fundamental, pois, sem o contexto situacional, não há nem texto, nem discurso. Portanto, a ênfase dada ao elemento 'situacional' respalda-se na concepção de que todos os eventos comunicativos são baseados em algum contexto. Em vista disso, pressupõe-se que o ‘texto' foi produzido por um falante com um destinatário em potencial, contando com objeções, correções, sinais de aprovação, etc. Isso evoca um contex to relevante, como ocorre na interação verbal, em que os participantes envolvidos possuem informações pragmáticas por parte do falante e do destinatário, suficientes para estabelecerem uma comunicação, como demonstrado em 2.1. Desse modo, percebemos que o dicionário de aprendizagem deve utilizar o contexto situacional como agente que contribui para a produção e para a compreensão de significados em eventos comunicativos, pois fornece elementos que influenciam nas etapas de formulação e de codificação, utilizados no componente gramatical. 


\section{2. 1. Texto, contexto e discurso no componente contextual da GDF}

Apontamos anteriormente que, na abordagem sobre o papel do contexto na GDF, Connolly (2007) afirma que o discurso é multimodal, incluindo aspectos linguísticos e extralinguísticos, em vista de que, no mundo contemporâneo, graças à tecnologia da informação, a multimídia é onipresente e isso não pode ser ignorado. Seguindo essa linha de pensamento, Cornish (2009) contribui para o modelo da GDF ao abordar detalhes que não foram abordados por Connolly (2007) sobre as definições de texto, contexto e discurso. Desse modo, destacamos alguns desses detalhes que contribuirão para a análise dos dados e que colaborarão com a elaboração da proposta de dicionário de aprendizagem de verbos do português do Brasil como segunda língua, o Dicverb/PSL.

Cornish (2009, p. 99) concebe texto, contexto e discurso como apresentaremos a seguir. Texto é concebido como a sequência de signos verbais e sinais não verbais conectados, à medida que discurso é 'co-construído' pelos participantes do discurso no ato de comunicação. Referente ao contexto, Cornish o concebe como o domínio de referência de determinado texto. $\mathrm{O}$ 'co-texto' é o gênero de evento de fala em andamento, o discurso construído, o ambiente sociocultural assumido pelo texto e pela situação específica, que está sujeito a um processo contínuo de construção e de revisão durante o evento comunicativo. Assim, são invocados os elementos relevantes tanto para o falante como para o destinatário. E, para esse autor, o discurso é concebido como o produto hierarquicamente estruturado, representado mentalmente na sequência dos enunciados, dos atos proposicionais e ilocucionários, que são indicativos de que os participantes do evento comunicativo apresentam intenção comunicativa relacionada a determinado contexto.

Desse modo, Cornish (2009) organiza o componente contextual com base na perspectiva do destinatário, em que o falante exige a inversão do nível 'textual' e do nível do 'discurso', ao incluir o fato da co-construção do discurso pelos participantes. O autor ressalta que na construção do texto deve ser observado em duas perspectivas: por um lado, do ponto de vista de quem fala, o discurso é criado tanto em termos de suas intenções comunicativas, quanto em função do feedback do destinatário; por outro lado, da perspectiva do destinatário, o discurso é construído por meio dos inputs procedentes do 'texto' e do 'contexto'. Assim, as textualizações do destinatário em relação ao enunciado do falante originam novo discurso, por meio de negociação entre os participantes, demonstrando, 
assim, simplificadamente, a inter-relação entre texto, discurso e situação de enunciação como parâmetros contextuais, com representado na figura a seguir:

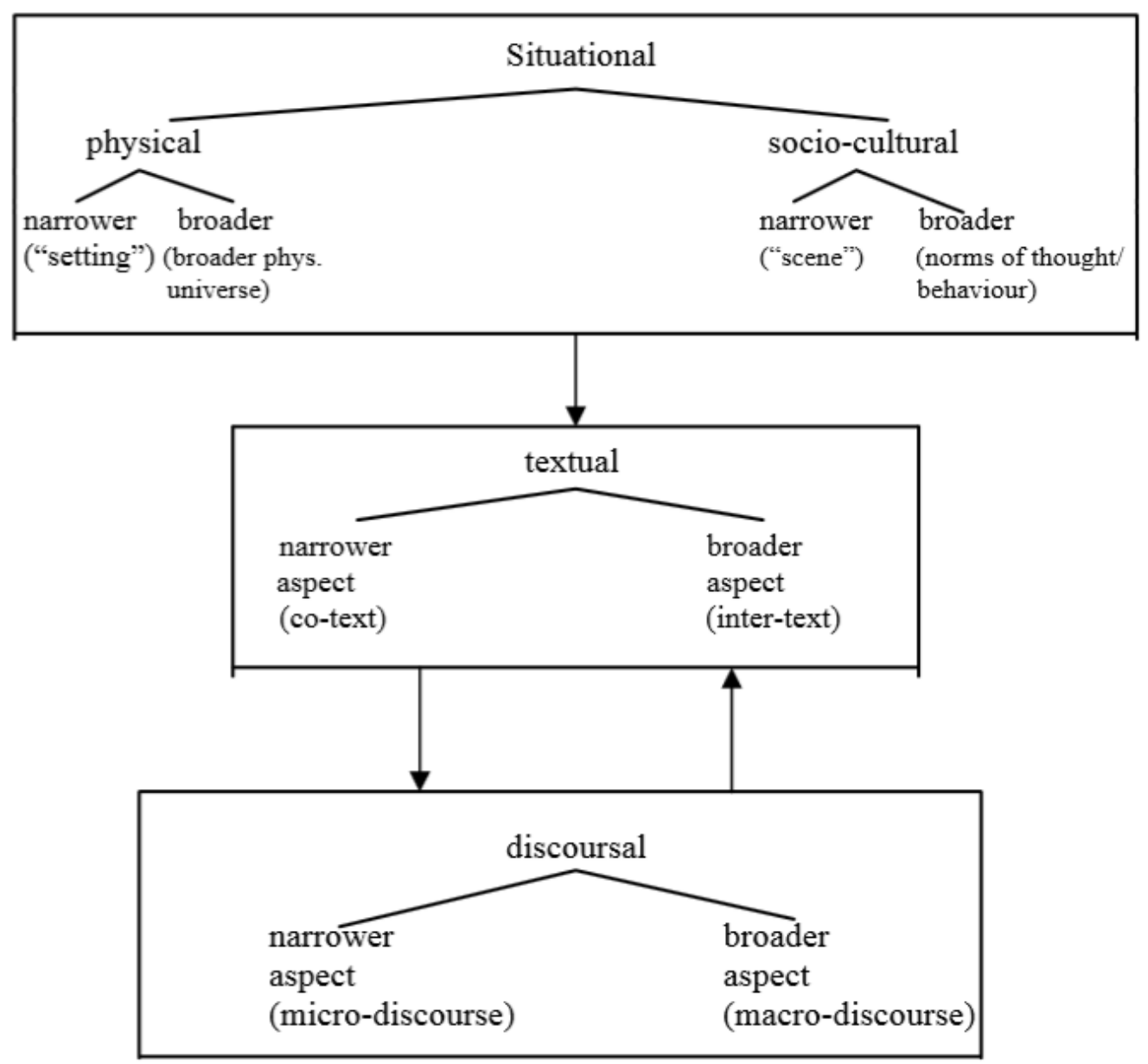

Figura 10: Relação entre as três principais partes de contexto - situacional, textual e discursivo.

Fonte: (CORNISH, 2009, p. 108)

Por isso, ao incluir o componente contextual na análise de língua, reconhecemos a funcionalidade desse componente em selecionar e restringir os lexemas pelas informações relevantes, disponíveis no contexto situacional, a fim de torná-los compatíveis como a produção e a compreensão dos enunciados.

Os aspectos teóricos que apresentamos até o momento corroboram para a inclusão do componente contextual nas obras lexicográficas. Essa inclusão tem a finalidade de contribuir para a produção e a compreensão dos significados, que são produzidos dentro de contextos específicos, junto com os componentes conceituais, gramaticais e de saída. Por conseguinte, enfatiza-se o dicionário como obra de referência de língua que contém 
elementos gramaticais e pragmáticos ao englobar esses aspectos. Desse modo, realçamos que a compreensão de textos, escritos ou falados, não significa simplesmente a decodificação da superfície textual, a fim de ter acesso às intenções do falante ou do escritor, mas sim um produto de um processo complexo, em que texto é compreendido como conjunto de informações para o discurso. Em razão disso, texto e discurso são construídos por meio de invocação de aspectos relevantes do contexto, características importantes no uso da linguagem, por oferecerem oportunidades ao falante para criar e adaptar enunciado, utilizando o sistema linguístico segundo suas intenções comunicativas, conforme propõem Connolly (2007) e Cornish (2009).

Portanto, nossa pesquisa incluirá, nas análises dos verbos, a perspectiva dos componentes contextual e conceitual, em vista de esses influenciarem nas operações de formulação e de codificação do componente gramatical. E, por entender que nessas operações as informações sintático-semânticas que descrevem verbos como de estado, de ação, de processo e de estado-processo e as informações morfossintáticas que descrevem número, pessoa, tempo e modo dos verbos são relevantes, completaremos nosso embasamento teórico com as concepções acerca de verbo de Chafe (1979), de Borba (1996; 2003), e de Castilho (2010).

\subsection{Atributos do verbo no processo de formulação e de codificação}

A presença dos verbos, ao lado dos nomes, destaca-se nas línguas, conforme demonstram vários estudos linguísticos. É um tipo de palavra que ocupa lugar privilegiado nos enunciados, pois contém informações que dão movimento ao discurso em vista da dinâmica desse tipo de palavra. Na língua portuguesa, por exemplo, o verbo demonstra elementos gramaticais como a pessoa do discurso, o tempo referido no enunciado, a atitude da pessoa que fala (certeza, dúvida, desejo), além de selecionar e restringir as palavras que o acompanharão no uso da língua, informações que são fornecidas pelos componentes conceitual e contextual.

Quanto à natureza do verbo, Chafe (1979, p. 96) declara que "dentro do universo conceitual humano o verbo é a área central que engloba estados e eventos". Neves (2000, p. 25) destaca que "os verbos, em geral, constituem os predicados das orações e que os predicados designam as propriedades ou relações que estão na base das predicações", em que predicado é o elemento que "tem propriedades sintáticas e semânticas, como a forma 
lexical, a categoria, o número e a função semântica dos termos, além das restrições de seleção a estes impostas". Bechara (2009, p. 209) descreve verbo como "a unidade de significado categorial que se caracteriza por ser um molde pelo qual organiza o falar seu significado lexical" e Castilho (2010, p. 396) considera o verbo como "a palavra que introduz participantes no texto", referindo-se às propriedades discursivas do verbo. De acordo com essas citações, reconhecemos o verbo como essencial para a produção e a compreensão de textos, pois compõe a base dos enunciados.

Nessa linha de pensamento, Borba (1996, p. 46), em sua gramática de valência, enfatiza a centralidade do verbo ao descrevê-lo como "nuclear e que os demais elementos oracionais se dispõem em torno deste núcleo através de relações de dependência", como ilustramos a seguir:

(4) João bebeu um suco.
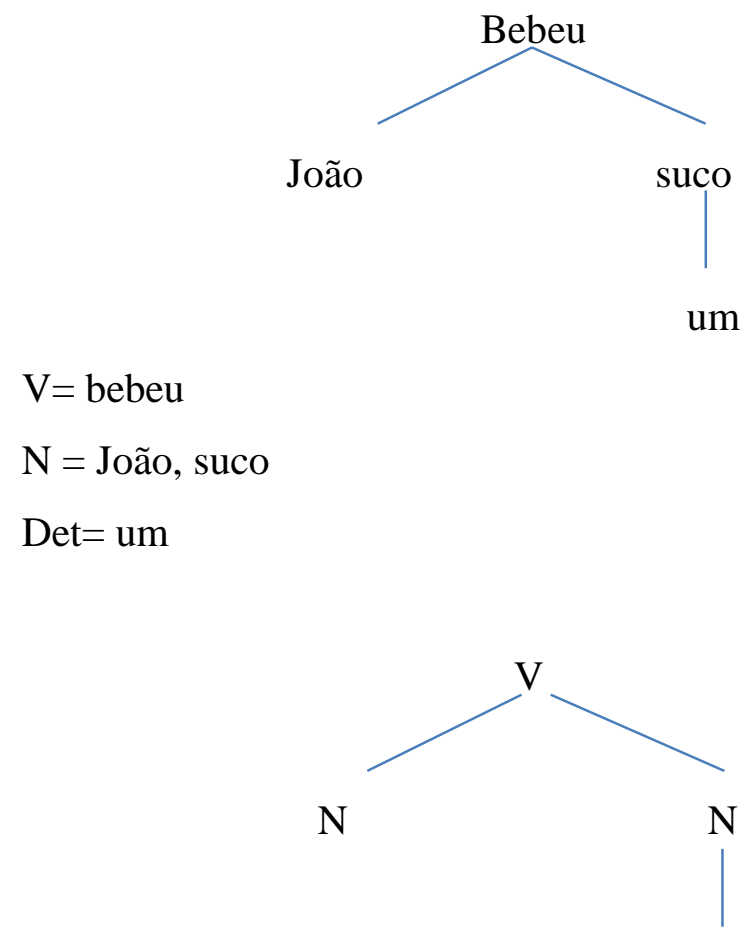

Det

Isto corrobora a ideia de que os verbos abrem "casas" para preenchimento, denominadas como complementos, na organização dos enunciados. Entretanto, devemos considerar que essa construção requer informações relevantes como: os conceitos dos lexemas beber, João e suco; bem como a intenção comunicativa do falante antes de produzir 
esse enunciado. Essas informações são fornecidas pelos componentes conceituais e contextuais. Logo, a relevância do verbo nas línguas conduz à inclusão dessa categoria gramatical em obras descritivas, como os dicionários, que visam à aprendizagem de língua.

A centralidade do verbo, no aspecto gramatical, direcionou pesquisas de naturezas diversas, como semânticas e sintáticas. Segundo as características semânticas, estudos relacionados aos verbos apresentam a existência de subcategorias verbais, que os diferenciam como: verbos de ação, de processo, de estado e de ação-processo. As características sintáticas descrevem o verbo como núcleo de um predicado, com capacidade de especificar o tipo ou os tipos de argumentos do enunciado que o acompanham. Os verbos são avaliados de acordo com a quantidade e o tipo de argumentos com que estabelecem relações. Em decorrência dessa avaliação, existem estudos sobre a valência verbal, que "tem por objetivo básico observar e determinar o comportamento do verbo no âmbito da frase", conforme afirma Borba (1996, p. 46). Assim, do ponto de vista quantitativo, os verbos são classificados como monovalente, bivalentes, trivalentes, tetravalentes e avalentes, conforme descreveremos.

\subsubsection{A tipologia semântica do verbo}

A observação de enunciados em contextos distintos demonstra que nem sempre um verbo representa a ação desempenhada por um ser, como por exemplo, nos enunciados abaixo, retirados de uma reportagem no Jornal Hoje, disponível no site G1.globo, sobre o nível de água do Sistema Cantareira que abastece a Grande São Paulo:

(5) As represas estão praticamente secas.

(6) A represa secou.

(7) Cientistas estudam a utilização do volume morto.

(8) A estiagem secou a represa.

Seguindo as diretrizes de Chafe (1979) e de Borba (1996 e 2003), verificamos que em (5) o verbo estar especifica um estado ou condição das represas, e não uma ação feita por essa estrutura de contenção de água. Em (6) a situação é outra, percebemos que o verbo secar não descreve um estado, mas sim um evento em que ocorre mudança, progressiva, de estado ou de condição da represa, especificando um processo. Nos casos registrados em (5) 
e em (6), os verbos estar e secar envolvem uma relação entre um nome, represa, que é paciente, e um estado.

O verbo do exemplo (7), estudar, demonstra não um estado, nem uma mudança de estado, ou seja, um processo, mas uma ação, atividade desempenhada pelo nome, cientistas. Nesse caso, o nome que acompanha o verbo é agente. Pela análise, observamos que encontramos outra distinção concernente a verbo no exemplo (8) em relação aos exemplos (5), (6) e (7), pois secar em A estiagem secou a represa especifica, ao mesmo tempo, tanto uma ação quanto um processo, desempenhados pelo verbo, porque envolve uma ação feita pelo nome estiagem, que no caso é agente, e uma mudança de estado do nome represa, que é paciente. Essas divergências foram percebidas por Chafe (1979) e Borba (1996 e 2003), os quais registram as subcategorias verbais como representamos na figura a seguir:

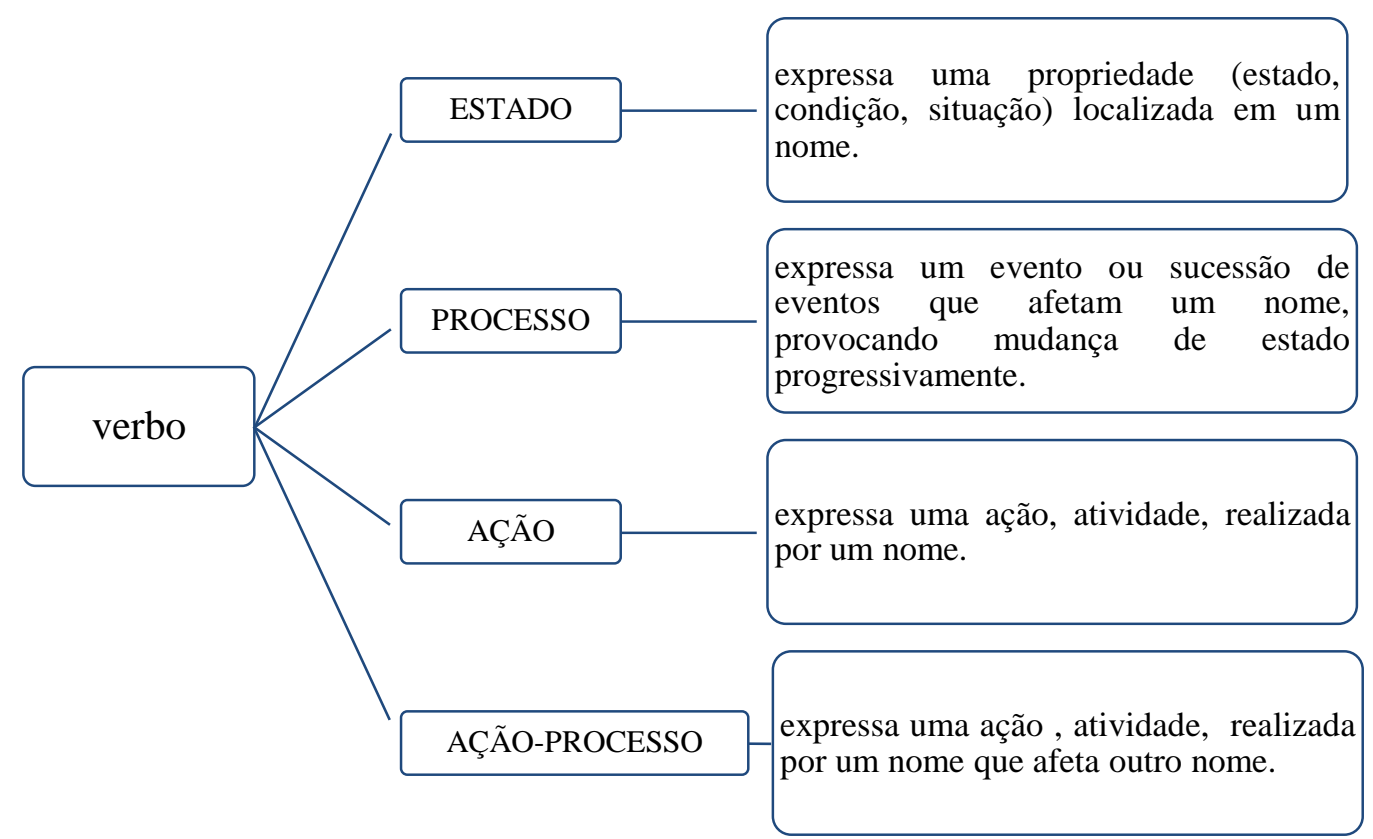

Figura 11: Tipologia semântica do verbo com base em Borba (1996 e 2003) e Chafe (1974)

Ressaltamos que a relação verbo-nome (agente e paciente) não é a única que um nome pode manter com um verbo, porém são as que desempenham um papel fundamental mais que quaisquer outras relações. As variações desses papéis podem estar ligadas, entre outras, aos participantes do enunciado, às intenções comunicativas e às situações em que os 
eventos comunicativos ocorrem. Chafe (1974, p. 148-172) e Borba (1996, p. 30-31) citam outros tipos como:

1. Agentivo, que por si mesmo, desencadeia uma atividade (física ou não), sendo origem dela e seu controlador.

2. Experimentador, que é o caso de evento psicológico genuíno, que traduz uma experiência ou uma disposição mental.

3. Beneficiário, que é um afetado cujo complemento expressa algo que passa a existir.

4. Temporal, que indica localização no tempo.

5. Comitativo, que é um afetado que expressa associação, marca o destinatário da posse (simples posse, perda ou ganho de posse).

6. Objetivo, que é a entidade em relação à qual se verifica uma situação, ou seja, o afetado que o verbo indica.

7. Locativo, que marca o lugar.

8. Instrumental, que exprime uma causa indireta tendo como traços básicos a atividade e o fato de ser controlado.

9. Causativo, que provoca um efeito ou o que desencadeia algo, expressa uma atividade ligada a um estímulo.

10.Meta, que expressa o ponto de chegada.

11.Origem, que expressa o ponto de partida.

12.Resultativo, que é um efetuado.

Quanto à característica nuclear do verbo, Castilho (2010, p. 397) reconhece a relação verbo-argumento (verbo-nome) do seguinte modo:

1. Predicados agentivos, tais como " $\mathrm{X}$ faz $\mathrm{Y}$ ".

2. Predicados experienciais, que exprimem propriedades de natureza perceptiva, cognitiva ou estados afetivos, tais como "X sabe/pensa/ama Y".

3. Predicados possessivos, ou de transferência de posse, tais como "X tem/possui/dá/recebe Y de/a Z".

4. Predicados locativos, em que se estabelecem uma relação não dinâmica de localização espacial, tais como "X está em/é de Y".

5. Predicados causativos, em que um dos argumentos designa a entidade que sofre uma mudança de estado ou de lugar, como " $\mathrm{X}$ abre/destrói/sobe Y.

Reconhecendo, assim, o papel dos complementos verbais que compõem os enunciados em relação aos verbos, apresentaremos a tipologia sintática dos verbos relacionada aos nomes que os acompanham. 


\subsubsection{Tipologia sintática dos verbos}

A seção anterior destacou a ocorrência de um nome que acompanha um tipo de verbo. Chafe $(1979$, p. 97) não se omite em relação à existência de nomes que estão em volta do verbo quando afirma que "o verbo dita a presença e a natureza dos nomes". Entretanto, percebemos que o número dos nomes que acompanham os verbos varia. Desse modo, abordaremos, brevemente, os conceitos que envolvem a quantidade e o tipo de complementos que, exigidos pelos verbos, os acompanham, com base em Borba (1996, p. 46). Utilizaremos enunciados, alguns elaborados por nós, inspirados nos exemplos e por Borba (1996), para ilustrar esses conceitos.

(9) Ventou.

(10) A chuva diminuiu.

(11) A estiagem secou a represa.

(12) A presidente entregou a taça aos vencedores.

(13) Ana transferiu o dinheiro de sua conta-corrente para a do pai.

O exemplo (9) demonstra a ocorrência de um verbo avalente, pois não exige a companhia de nenhum nome. São os denominados verbos impessoais, entre os quais os que indicam fenômenos atmosféricos. Em (10), somente um nome acompanha o verbo, expressa a ocorrência de um verbo monovalente. A ocorrência do verbo denominado bivalente aparece em (11), pois, como observamos, o verbo secar exige os nomes estiagem e represa. No enunciado (12), observamos três nomes em volta do verbo entregar, que o complementam, por isso a esse tipo verbal denomina-se trivalente. E o último exemplo (13) chama atenção para a ocorrência de um verbo tetravalente, transferir, em vista de exigir a presença de quatro nomes, a saber: Ana, dinheiro, conta-corrente e pai. Por isso, é relevante o estudo de valência verbal para compreender o comportamento do verbo, observando a variedade de usos que a língua utiliza na organização dos enunciados segundo o valor contextual específico.

A identificação de tipos diferentes de complementos revela que há argumentos internos e argumentos externos ao verbo.

Os verbos monovalentes apresentam um único argumento que se mantém fora da estrutura interna do verbo que compõe o predicado, têm a forma $\mathrm{C}_{1}+\mathrm{V}$. 
Exemplo (10):

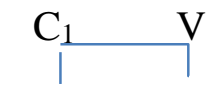

A chuva diminuiu.

Os verbos bivalentes apresentam dois argumentos, um se mantém fora da estrutura interna do verbo e outro se mantém dentro da estrutura do verbo, que pode vir ou não preposicionado, têm a forma $\mathrm{C}_{1}+\mathrm{V}+\mathrm{C}_{2}$.

Exemplo (11):

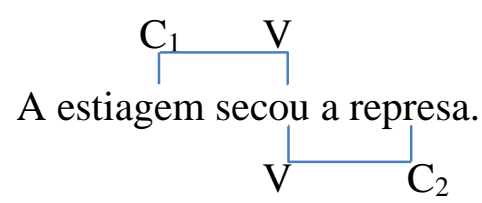

Os verbos trivalentes apresentam três argumentos, um se mantém fora da estrutura interna do verbo e os outros dois mantêm-se na estrutura interna do verbo, sendo um dos internos preposicionado, a forma $\mathrm{C}_{1}+\mathrm{V}+\mathrm{C}_{2}+$ prep $+\mathrm{C}_{3}$ :

Exemplo (12):

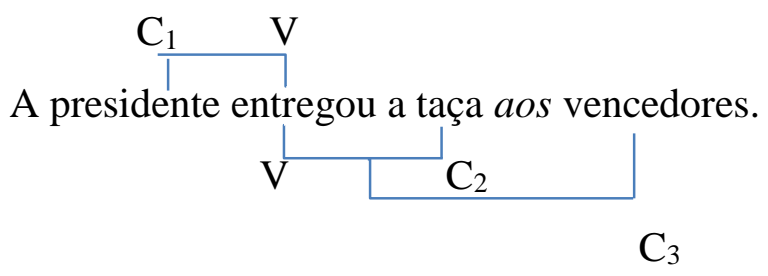

Os verbos tetravalentes apresentam quatro argumentos, um se mantém fora da estrutura interna do verbo e os outros três mantêm-se na estrutura interna do verbo, sendo dois dos internos preposicionados, têm a forma $\mathrm{C}_{1}+\mathrm{V}+\mathrm{C}_{2}+$ prep $+\mathrm{C}_{3}+$ prep $+\mathrm{C}_{4}$.

Exemplo (13):

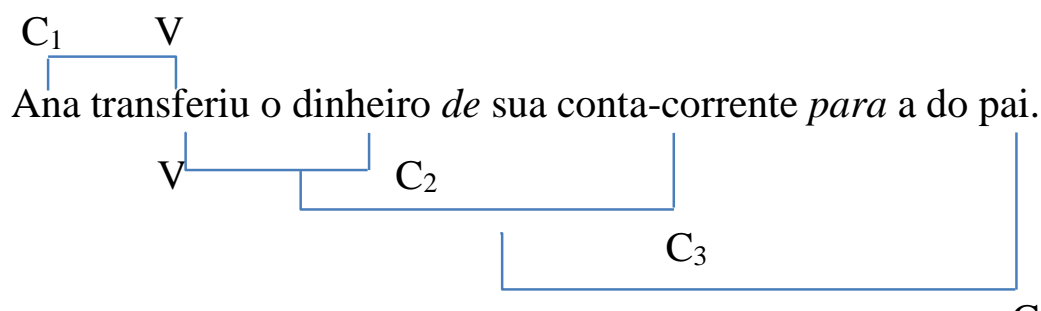


Em que:

$\mathrm{V}=$ verbo (predicador)

$\mathrm{C}_{1}, \mathrm{C}_{2}, \mathrm{C}_{3}$ e $\mathrm{C}_{4}=$ complementos (argumentos)

prep $=$ preposição

Outro ponto destacado por Borba (1996, p. 47) relativo ao aspecto sintático do verbo é que, além dos nomes, que são maioria, pode haver advérbios e orações como complementos. Além disso, mencionamos o fato de que os complementos verbais expressos por nomes ou orações podem ser ou não introduzidos por preposições. Desse modo, faz-se necessária a identificação das características semânticas e sintáticas dos verbos para compreender os significados em contextos situacionais distintos.

\subsection{Os verbos segundo as diretrizes conceitual, contextual, semântica e sintática}

O objeto de estudo desta pesquisa são os verbos da língua portuguesa em contexto de uso dos brasileiros, e os conceitos sobre o componente conceitual, o componente contextual, a tipologia semântica, a tipologia sintática relacionam-se com a finalidade de investigar a contribuição do contexto para a significação dos verbos no dicionário de aprendizagem. A fim de ilustrarmos a interação desses conceitos relacionados ao significado do verbo em contexto restrito, retomamos o exemplo (11).

$\mathrm{O}$ enunciado A estiagem secou a represa faz parte de um evento comunicativo registrado em reportagem divulgada em jornal de grande circulação que tinha a intenção de informar à população brasileira a situação do Sistema Cantareira, complexo de reservatórios que abastece a região da Grande São Paulo, pelo fato de esse sistema ser importante para a provisão de água.

(11) A estiagem secou a represa.

O componente conceitual interagindo com o nível interpessoal, representado na estrutura abaixo (a), contribuiu para a compreensão dos aspectos formais das unidades linguísticas. Reflete o papel da unidade na interação entre os participantes do ato discursivo, pois descreve as estratégias empregadas para se conseguir os objetivos comunicativos, englobando as noções retóricas de toda a estruturação do discurso, com a finalidade de 
representar os conceitos extralinguísticos em forma linguística, como a intenção do jornal em informar a situação do Sistema Cantareira à população.

a) Nível interpessoal:

$\left(\mathrm{M}_{\mathrm{I}}:\left[\left(\mathrm{A}_{\mathrm{I}}:\left[\left(\mathrm{F}_{\mathrm{I}}: \mathrm{DECL}\left(\mathrm{F}_{\mathrm{I}}\right)\right):\left(\mathrm{P}_{\mathrm{I}}\right)_{\mathrm{S}} \quad\left(\mathrm{P}_{\mathrm{J}}\right)_{\mathrm{A}} \quad\left(\mathrm{C}_{\mathrm{I}}:-\mathrm{A}\right.\right.\right.\right.\right.$ estiagem secou a represa $\left.\left.\left.\left.\left.\left(\mathrm{C}_{\mathrm{i}}\right)\right)\right]\left(\mathrm{A}_{\mathrm{I}}\right)\right)\right]\left(\mathrm{M}_{\mathrm{I}}\right)\right)$

O nível representacional contribui para a compreensão do processo da designação, em que os lexemas são introduzidos como representações de categorias semânticas com conteúdo básico, que podem ser ampliadas ou adaptadas à medida que outros fatores impulsionem a criação de novos significados. Em eventos comunicativos novas funções podem ser desempenhadas, relacionadas ao mundo real ou mundo imaginário, originando a ressemantização dos itens lexicais. Assim sendo, permite que o usuário acesse o fundo lexical, que contém os lexemas básicos e as regras do sistema linguístico para derivá-los, de acordo com as informações fornecidas pelo componente contextual.

b) Nível representacional:

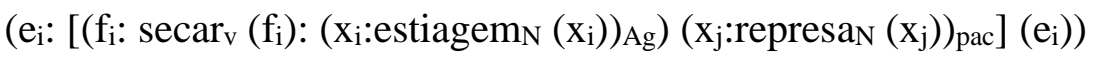

Assim, considerando que este enunciado é fruto de uma interação verbal, por exercer função representativa da linguagem integrada à função interpessoal e social, a contribuição do contexto situacional é fundamental, em vista de o contexto físico e o contexto social fornecerem informações sobre o 'cenário' e a 'cena' do evento comunicativo. Para isso é necessário haver interação entre o modo de organização social, as normas de pensamento e de comportamento, associados ao papel que o Sistema Cantareira desempenha pelas propriedades físicas e sociais. E que, no momento do evento comunicativo, apresenta um estado que afeta negativamente a sociedade brasileira, devido às condições climáticas da região, por isso a necessidade de produzir um enunciado que informe essa situação.

Para tanto, as entidades que compõem o enunciado organizam-se, segundo as regras sintáticas da língua e as propriedades lexicais, distribuindo os participantes do enunciado, de acordo com a relação verbo-nome, e segundo as intenções comunicativas e as situações em que o evento comunicativo ocorre. A seleção dos lexemas, no evento comunicativo, 
ocorre em função da valência verbal, das funções semânticas e das restrições impostas pelos contextos, demonstrando a importância dos lexemas.

c) relação sintático-semântica do verbo

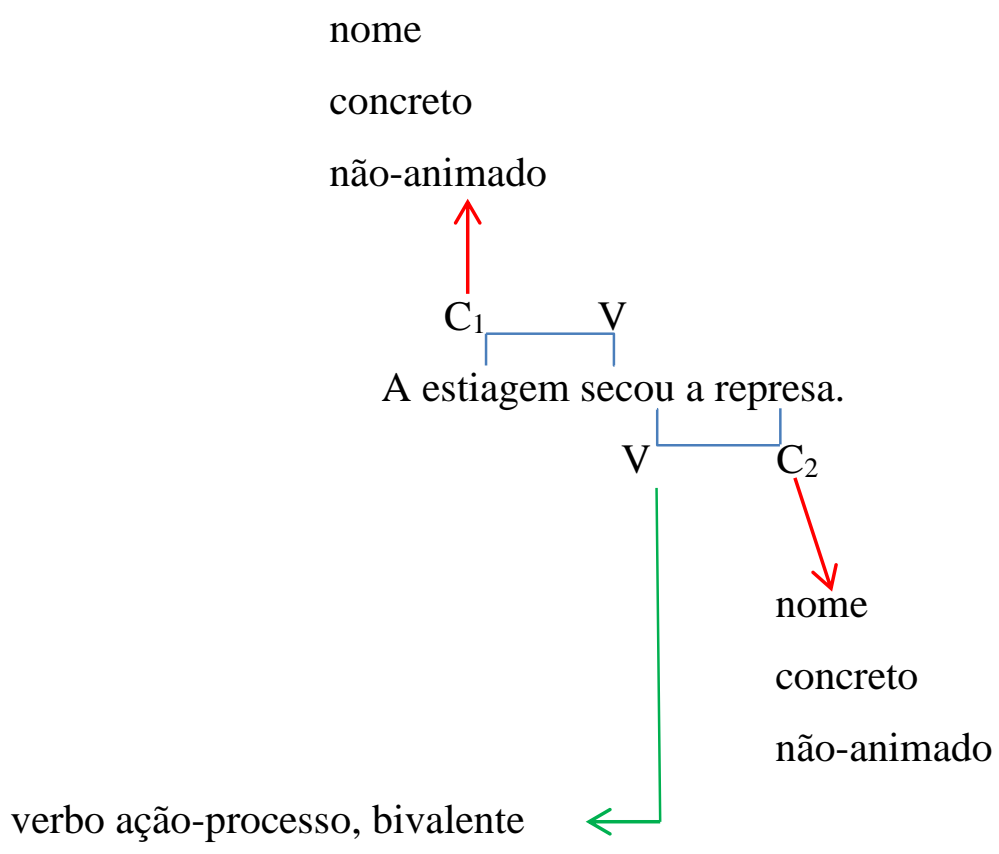

O embasamento teórico que apresentamos sustentam os aspectos linguísticos que conduzirão as análises dos verbos selecionados, bem como nossas escolhas na elaboração do dicionário de aprendizagem, o Dicverb/PL2. As reflexões feitas até o momento serão aplicadas no capítulo 5, reservado para apresentar a análise de dados, e, no capítulo 6, reservado para apresentar a proposta para o dicionário de aprendizagem de verbos do português do Brasil como L2. 


\subsection{Síntese do capítulo}

Neste capítulo, expusemos o embasamento teórico que sustenta o papel do contexto como agente contribuidor para a significação, por meio da apresentação dos conceitos da Gramática Discursivo Funcional (GDF) e de ilustrações que auxiliam a compreensão da teoria. Destacamos o componente conceitual e o componente contextual por sua interrelação com o componente gramatical, no âmbito da GDF. Além disso, descrevemos os atributos do verbo, dando ênfase a sua tipologia semântica e sintática, com vistas a compreender a centralidade dessa categoria lexical na produção e na compreensão de enunciados. Desse modo, entendemos que foram expostos os aspectos teóricos relevantes que dão caráter linguístico às análises dos verbos selecionados, bem como os critérios linguísticos para a elaboração da proposta de dicionário de aprendizagem de verbos do português do Brasil como segunda língua, o Dicverb/PL2. 


\section{CAPÍTULO 3 - METODOLOGIA PARA ELABORAÇÃO DE UMA PROPOSTA DE DICIONÁRIO DE APRENDIZAGEM DE PSL}

Para o desenvolvimento da pesquisa científica que empreendemos, procuramos responder a perguntas de diversas naturezas: i) Como elaborar um dicionário para aprendizes de L2? ii) Que tipo de corpus de análise orienta a elaboração de um dicionário? iii) Como armazenar e organizar esse corpus? iv) Quais elementos devem compor a macroestrutura e a microestrutura desse dicionário? v) Como demonstrar a eficiência e a utilidade de uma proposta de dicionário de L2? Vi) Como divulgar esse dicionário? Para responder a essas e outras perguntas, é preciso desenvolver uma metodologia que satisfaça as exigências da obra.

Neste capítulo, apresentaremos o caminho que percorremos para a elaboração desta pesquisa, com vistas à organização de um ponto central, que é a da microestrutura de dicionários para a aprendizagem de língua. O conteúdo principal são os verbos, extraídos de contextos básicos do cotidiano, pois o conjunto de informações lexicográficas conduz os usuários de determinada língua à construção do saber léxico. Nesse sentido, o dicionário demonstrará os significados que os verbos contêm em contextos de uso específicos. Assim, o aprendiz poderá compreender os significados distintos e utilizá-los de modo mais apropriado no evento comunicativo. Essa proposta sustenta-se nos estudos de Lexicologia e de Lexicografia de Borba (2003), Chafe (1979), Faulstich (1990, 1993, 1998 e 2010), Guerra (2003), Haensch (1982, 1997), Lara (1997) e Rey-Debove (1971 e 1984), relacionados à teoria da GDF de Hengeveld e Mackenzie (2008; 2010) e às contribuições de Connolly (2007) e Cornish (2009) à teoria da GDF.

Nesta pesquisa, de natureza qualitativa, o método descritivo foi adotado para que os fatos de língua, coletados por meio de dados, fossem observados, registrados em fichas apropriadas, para posteriormente serem analisados e categorizados. Esse procedimento considera a importância de um paradigma lexicográfico para a construção de uma proposta de dicionário para aprendizes de português como L2.

A seguir, apresentamos o caminho percorrido. 


\subsection{Metodologia}

O objeto de estudo desta tese são os verbos da língua portuguesa e os objetivos são: i) analisar como os verbos estão organizados na microestrutura de dicionários para a aprendizagem; ii) analisar como a microestrutura de verbos favorece a aprendizagem do léxico da língua-alvo; iii) organizar a microestrutura de dicionários para aprendizes de PSL de acordo com o significado dos verbos; iv) estruturar as informações sobre os verbos de acordo com o significado para o aprendiz no processo de aprendizagem da língua-alvo e v) elaborar uma proposta de dicionário de verbos para aprendizagem de PSL.

A escolha da categoria verbo se justifica porque "engloba estados (condições, qualidades) e eventos [...] que são centrais" em relação ao universo conceitual humano, de acordo com Chafe (1979, p. 96), e porque o verbo é considerado elemento selecionador, pois "determina como deverá ser o restante da oração, principalmente, determina que nomes o acompanharão, qual será a relação desses nomes com o verbo, e como esses nomes serão semanticamente especificados" (CHAFE, 1979, p. 97). Desse modo, as informações sobre essa categoria devem estar bem descritas nos dicionários para possibilitar o uso em cláusulas discursivas.

A metodologia está organizada nas seguintes etapas: Delimitação do objeto de estudo; Delimitação do perfil do público-alvo do dicionário de L2; Seleção dos contextos em usos da linguagem do cotidiano brasileiro em que ocorrem os verbos; Recolha e tratamento do corpus para suporte de análise; Análise de dados; Tratamento dos verbos quanto à polissemia e à homonímia. Essas etapas dão corpo à pesquisa, como descreveremos a seguir.

\subsubsection{Delimitação do objeto de estudo}

Um dicionário é obra de referência de uma língua, que, com finalidade pedagógica e organizado para atender às necessidades linguísticas do aprendiz de língua. Por conseguinte, orienta esse usuário do dicionário a obter informações da língua-alvo para proporcionar a interação entre os falantes da língua em aprendizagem por meio da produção e da compreensão de pensamentos variados. Entre outras informações, os dicionários orientam o aprendiz a conhecer questões sobre ortografia, pronúncia, significados, informações sintáticas e pragmáticas, equivalência entre línguas, no caso dos dicionários bilíngues. 
O ponto de partida para esta pesquisa foi a seleção de verbos, por ser uma unidade linguística que conduz pelo léxico a relação entre a sintaxe, a semântica e o contexto sociocultural da língua portuguesa do Brasil.

\subsubsection{Delimitação do perfil do público-alvo do dicionário de PSL}

O público-alvo determina a tipologia e a estrutura de obras lexicográficas. $\mathrm{Na}$ elaboração de dicionário, o lexicógrafo seleciona o público para o qual a obra destina-se. Como já destacamos, por se referirem a usuários com necessidades diversificadas, é necessário determinar, na fase inicial de elaboração, quem será o consulente do dicionário, pois essa decisão influenciará o conteúdo das informações linguísticas e extralinguísticas da obra.

Assim, em vista do aumento considerável de estrangeiros que desejam residir no país, delimitamos, como público-alvo, falantes que tenham a língua inglesa como L1 ou LE, residentes no Brasil, adultos, com mais de 18 anos, com escolarização equivalente ao Ensino Médio no sistema de educação brasileiro e iniciantes na aprendizagem do português.

A escolha de falantes da língua inglesa decorre do fato de existirem estrangeiros residentes no Brasil que possuem o inglês como primeira língua (L1) ou como língua estrangeira (LE), conforme constatamos em nossa experiência de docência. Entretanto, destacamos que há carência de dicionários pedagógicos do português como L2, seja bilíngue, seja semibilíngue, seja monolíngue, para falantes do francês, russo, japonês, ucraniano, alemão, espanhol, entre outros.

\subsubsection{Seleção dos contextos do cotidiano brasileiro em que ocorrem os verbos}

Determinado o objeto de estudo e o público-alvo do dicionário, identificamos os verbos usados em contextos do cotidiano dos brasileiros, por meio de contextos mais usados na conversação do dia a dia dos brasileiros.

Os contextos foram selecionados de acordo com os temas abordados em livros didáticos de PSL e com as diretrizes apresentadas na obra Português Fundamental ${ }^{16}$, de

\footnotetext{
${ }^{16}$ Conhecemos o conteúdo dessa obra como pesquisadora de iniciação científica - PIBIC/UnB - sob a orientação da profa. Enilde Faulsticha, em 2006.
} 
Nascimento (1984). Para a coleta de dados selecionamos os livros: Novo Avenida Brasil 1 curso básico de Português para Estrangeiros - livro-texto + livro de exercícios, da editora EPU (2009), e Bem-Vindo! A Língua Portuguesa no Mundo da Comunicação, da Editora Pontes (2005). Esses livros foram selecionados porque os textos apresentam um léxico em contextos acerca de atividades essenciais dos seres humanos na sociedade moderna, como, por exemplo: comer, beber, habitar, comprar, trabalhar, estudar, viajar, divertir-se, hospedarse, apresentar-se, locomover-se, comportar-se na sociedade brasileira, relacionar-se com as pessoas, cuidar da saúde, pedir e dar informações pessoais.

O Português Fundamental foi elaborado como uma obra que "se destina essencialmente aos professores de Português como segunda língua e como língua estrangeira [...] concebida como um instrumento de trabalho para ser utilizado na elaboração de materiais didáticos" (NASCIMENTO, 1984, p. 9). O objetivo de fornecer dados sobre conteúdos lexicais adequados ao ensino do português, teve como "critérios empregados, segundo princípios de estatística lexical, a partir de amostragens do português falado europeu" ((NASCIMENTO, 1984, p. 9).

O Português Fundamental, de Nascimento (1984), registrou as conversas que, normalmente, restringem-se às seguintes situações:

1) Vida pessoal (habitação, alimentação, vestuário, saúde e doença, férias, passatempos, diversões, desporto e serviço militar);

2) Vida familiar (casa, vida doméstica, vida afetiva, namoro, casamento, relações familiares, filhos, educação e estudo);

3) Vida profissional (profissões e ofícios, trabalho e relações de trabalho, serviços domésticos, salários, negócios, comércio, férias trabalhista);

4) Vida social (cidade, província, campo, amizades, festas, festividades religiosas, convívio e contraste de gerações, turismo, redes sociais);

5) Problema econômico e social (custo de vida, rendimentos e preços, compras, comércio e indústria, agricultura, emigração);

6) Vida político-administrativa (administração pública, serviços públicos);

7) Vida cultural e artística (arte e artesanato, livros, teatro, cinema, televisão, música, imprensa, internet) meio ambiente (tempo, clima, fauna e flora, meio urbano, meio rural, campo, praia e trânsito). 
Decidimos que essas informações, ainda que decorridos 31 anos desde sua publicação, são atuais e servem a nosso propósito. Assim sendo, selecionamos os verbos que servirão de base para o estudo dos verbos em contextos específicos, a saber:

1) Alimentação, contextos relacionados à ação, ao estado ou ao processo de alimentar ou nutrir o corpo com substâncias digeríveis pelo organismo.

2) Atividades comerciais, contextos relacionados à ação, ao estado ou ao processo de atividades de troca, de venda ou de compra de bens, de produtos, de mercadorias e de serviços.

3) Atividades domésticas, contextos relacionados à ação, ao estado ou ao processo, que envolvem as atividades, a administração ou a organização do lar, da família, da vida particular de uma pessoa,

4) Clima e tempo, contextos relacionados à ação, ao estado ou ao processo, que envolvem as condições atmosféricas que exercem influência sobre a vida na Terra, que caracterizam determinadas regiões ou condições meteorológicas.

5) Crime e violência, referentes aos contextos relacionados à ação, ao estado ou ao processo, que envolve a transgressão moral ou ética, socialmente rejeitada pelos brasileiros, seja por ação, seja por omissão, empregando força física ou psicológica, passível de punição pela lei penal.

6) Educação, contextos relacionados à ação, ao estado ou ao processo, que envolvem o desenvolvimento físico, intelectual, social e moral do ser humano, e que assegure sua formação sócio-histórico-cultural, seja em ambiente familiar, seja em ambiente formal.

7) Esportes, contextos relacionados à ação, ao estado ou ao processo, que envolvem as práticas, individuais ou coletivas, de jogos e de exercícios físicos, seja com fins de recreação, seja com fins de condicionamento corporal para benefício da saúde, seja para competições esportivas.

8) Festas e festividades, contextos relacionados à ação, ao estado ou ao processo, que envolvem reuniões de pessoas com fins recreativos, enquadrando-se as festas familiares, as solenidades civis e as de caráter religioso.

9) Lazer, contextos relacionados à ação, ao estado ou ao processo, que envolvem o tempo utilizado para o ócio, o descanso e as atividades prazerosas. 
10) Moradia, contextos relacionados à ação, ao estado ou ao processo de residir, habitar, viver em barraco, casa, apartamento, mansão ou outro lugar.

11) Profissão e trabalho, contextos relacionados à ação, ao estado ou ao processo, que envolvem ofício, trabalho, ocupação, atividade profissional em que uma pessoa visa obter recursos financeiros como remuneração ou salário.

12) Relações sociais, contextos relacionados à ação, ao estado ou ao processo, que envolvem o convívio entre pessoas ou grupo de pessoas com interesses comuns, com fins particulares, profissionais, familiares, emocionais, de acordo com a cultura e a sociedade local.

13) Saúde e doenças, contextos relacionados à ação, ao estado ou ao processo, que envolvem condições físicas e psíquicas, proporcionando o bem-estar, e que, quando não estão equilibradas, provocam enfermidade, mal, moléstia aos seres vivos, podendo apresentar sintomas.

14) Tabuísmo, contextos relacionados à ação, ao estado ou ao processo, que envolvem comportamentos, palavras ou expressões consideradas chulas, grosseiras ou ofensivas em determinados contextos sociais.

15) Trânsito e transportes, contextos relacionados à ação, ao estado ou ao processo, que envolve a movimentação, o trajeto, as passagens ou o deslocamento em determinado lugar, com utilização ou não de veículos.

16) Vestimentas e indumentárias, contextos relacionados à ação, ao estado ou ao processo, que envolvem o hábito sociocultural de utilizar roupas e acessórios para vestir o corpo ou partes do corpo.

17) Viagens e hospedagem, contextos relacionados à ação, ao estado ou ao processo que envolvem os deslocamentos de um lugar para outro, relativamente distantes, normalmente com finalidade profissional ou de entretenimento e turismo.

\subsubsection{Metodologia para recolha e tratamento do corpus para suporte da análise}

Como a elaboração de um dicionário de verbos faz parte deste estudo, a coleta de dados visa identificar quais são os verbos que ocorrem nos contextos selecionados. Optamos, na primeira fase, por coletar dados de textos escritos e, depois de identificados, os verbos passaram a ser analisados em outras fontes, como internet e canais televisivos, para percepção dos diferentes modos de uso. 
Para compor o corpus inicial, recolhemos dados selecionados de revistas e jornais, de grande circulação no Brasil, que exercem influência nacional e que estão disponíveis em versões eletrônicas, com verbos selecionados de acordo com os temas. Enquadram-se nesses critérios as revistas da Editora Globo e da Editora Abril e jornal Folha de São Paulo, como apresentamos a seguir:

1) Alimentação: Revista Veja Comer \& Beber. Editora Abril. Disponível em: http://vejabrasil.abril.com.br/portal;

2) Atividades comerciais (compra e venda): Revista Exame. Editora Abril. Disponível em: http://www.folha.uol.com.br;

3) Atividades domésticas: Revista Vida simples. Editora Abril. Disponível em: http://vidasimples.abril.com.br;

4) Clima e tempo: Jornal Folha de São Paulo. Disponível em: http://www.folha.uol.com.br;

5)Crime e violência: Jornal Folha de São Paulo. Disponível em: http://www.folha.uol.com.br; Jornal o Globo disponível em : G1.globo. com;

6) Educação: Revista Nova Escola. Editora Abril. Disponível em: http://revistaescola.abril.com.br;

7) Esportes: Site do Globo Esporte. Disponível em: http://globoesporte.globo.com;

8) Festas e festividades: Jornal Folha de São Paulo. Disponível em: http://www.folha.uol.com.br;

9) Lazer: Jornal Folha de São Paulo. Disponível em: http://www.folha.uol.com.br;

10) Moradia: Arquitetura \& Construção. Editora Abril. Disponível em: http://casa.abril.com.br/arquitetura-construcao, e Revista Globo Rural. Editora Globo. http://revistagloborural.globo.com/, Jornal Folha de São Paulo. Disponível em: http://www.folha.uol.com.br/;

11) Profissão e trabalho: Exame. Editora Abril. Disponível em: http://exame.abril.com.br/ Jornal Folha de São Paulo. Disponível em: http://www.folha.uol.com.br; 
12) Relações sociais: $\quad$ Família. Disponível em

http://mdemulher.abril.com.br/familia, Revista Caras. Disponível em: http://caras.uol.com.br;

13) Saúde e doenças: Revista Saúde. Editora Abril. Disponível em: http://mdemulher.abril.com.br/revistas/saude;

14) Trânsito e transportes: Jornal Folha de São Paulo. Disponível em: http://www.folha.uol.com.br;

15) Vestimentas e indumentárias: Revista Estilo de vida. Editora Abril. Disponível em: http://mdemulher.abril.com.br/revistas/estilo;

16) Viagens e hospedagem: Revista Viagem. Editora Abril. Disponível em: http://viajeaqui.abril.com.br/vt. Revista Viagem. Editora Abril. Disponível em: http://viajeaqui.abril.com.br/vt;

Na segunda etapa, optamos por selecionar 3 textos de cada fonte escolhida, formando um total de 66 textos relacionados aos contextos. Esses textos foram transformados em documentos do tipo txt. para serem processados no software AntConc 3.2.4 ${ }^{17}$ (Windows), cuja finalidade é o tratamento de textos por meio de sistema automático. Como resultado, obtivemos um total de 41.247 itens lexicais, dos quais 8.452 eram itens distintos, com frequência entre 1 - para vários itens como ÓTIMA, VÊM, VOLTOU - e 1.922 - para a preposição DE. Desse montante, coletamos 895 verbos, como lemas, entendidos como verbos no infinitivo, conforme anexo 3 .

O software permitiu organizar os textos para, posteriormente, extrairmos os itens lexicais, seja em suas formas simples ou complexas, fornecendo lista de palavras de todos os textos, nas frequências e nas concordâncias.

O AntConc 3.2.4w (Windows) contém 7 (sete) ferramentas de processamento de dados:

1) Concordance Tool: apresenta o resultado da pesquisa de acordo com a palavrachave no contexto, fornecendo a palavra e a frase comumente usada em um corpus de textos.

\footnotetext{
${ }^{17}$ O software AntConc 3.2.4w (Windows) é de criação de Laurence Anthony. É uma ferramenta gratuita de análise de corpus do Centro de Idioma de Inglês e Educação em Ciência e Engenharia, Faculdade de Ciências e Engenharia da Universidade de Waseda, Japão. Disponível no site Laurence Anthony's Website, http://www.antlab.sci.waseda.ac.jp/software.html .
} 
2) Concordance Plot Tool: apresenta os resultados da pesquisa localizados com um formato de 'código de barras', permitindo a visualização da posição em que os resultados da pesquisa aparecem em textos-alvo.

3) File View Tool: apresenta o texto de arquivos individuais, permitindo a investigação mais detalhadamente dos resultados gerados em outras ferramentas de AntConc.

4) Clusters/N-Grams: apresenta os dados armazenados com base na condição de pesquisa, quer dizer, resume os resultados gerados na Concordance Tool ou Concordance Plot Tool. Essa ferramenta verifica todo o corpus para "N" (por exemplo, uma palavra, duas palavras, ...). Isso permite encontrar expressões comuns em um corpus.

5) Collocates: apresenta as colocações de um termo de pesquisa, permitindo a investigação dos padrões não-sequenciais na linguagem.

6) Word List: apresenta todas as palavras do corpus em uma lista ordenada por frequência, permitindo a localização das palavras mais frequentes no texto.

7) Keyword List: apresenta as palavras que são extraordinariamente frequentes (ou pouco frequentes) no corpus, em comparação com as palavras em um corpus de referência, permitindo a identificação das palavras características do corpus.

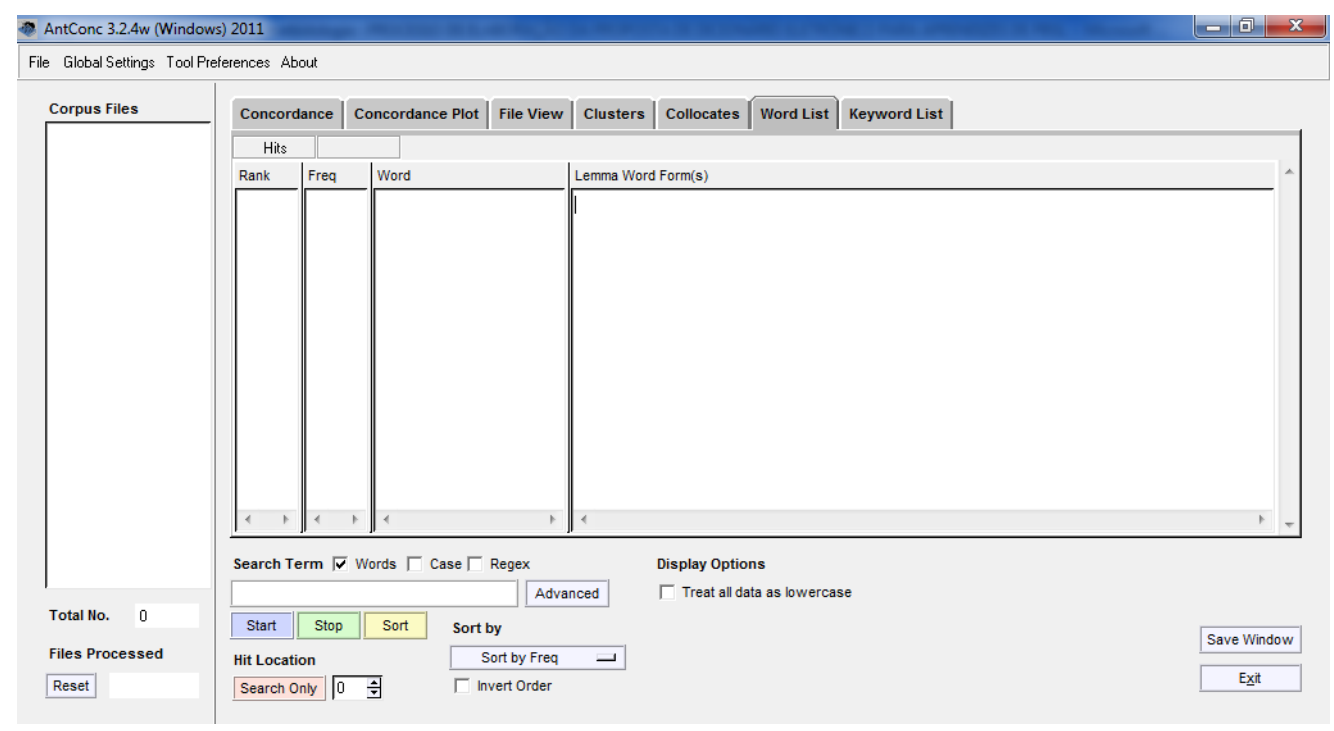

Figura 12: Representação do software AntConc 3.2.4w (Windows)

Os textos selecionados para esta pesquisa foram indexados no programa e processados. A ferramenta word list forneceu uma lista de palavras contendo todas as palavras dos textos e sua respectiva frequência. 
Os itens lexicais fornecidos são apresentados com a forma do texto de origem, ou seja, apresentam-se flexionados de acordo com a concordância exigida pela gramática do enunciado.

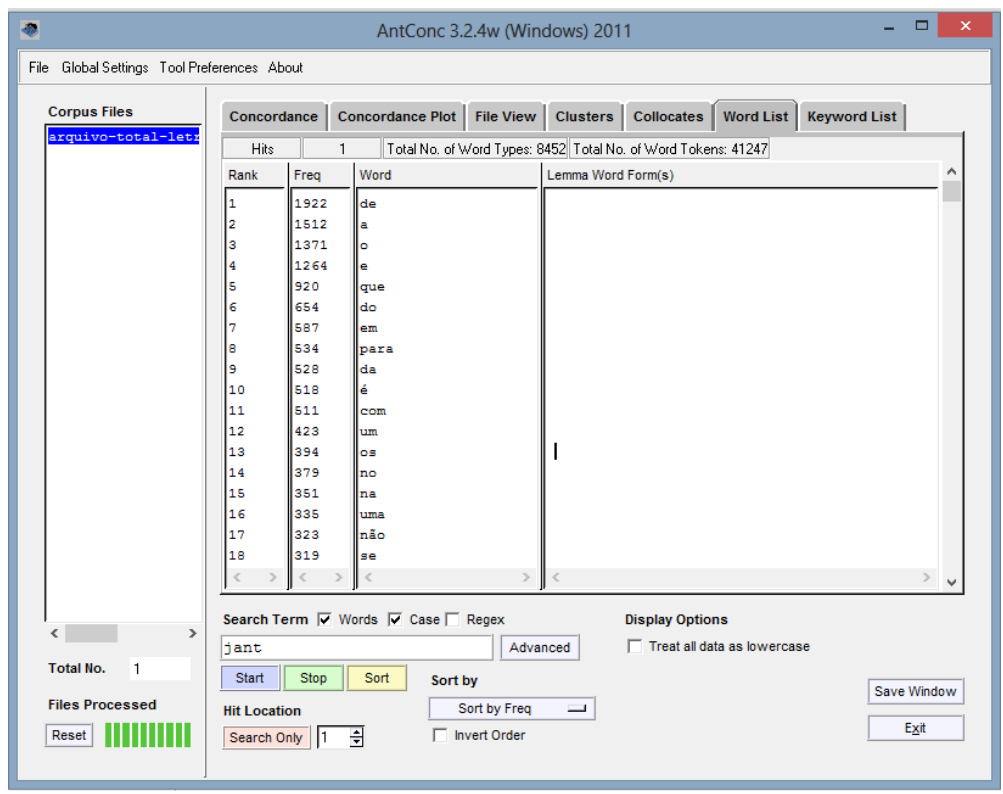

Figura 13: Lista de palavras do somatório dos 66 textos

Após a composição da lista de palavras do texto, com quantidade e frequência, foi possível verificar o contexto linguístico em que cada item aparece, por meio da ferramenta colocação.

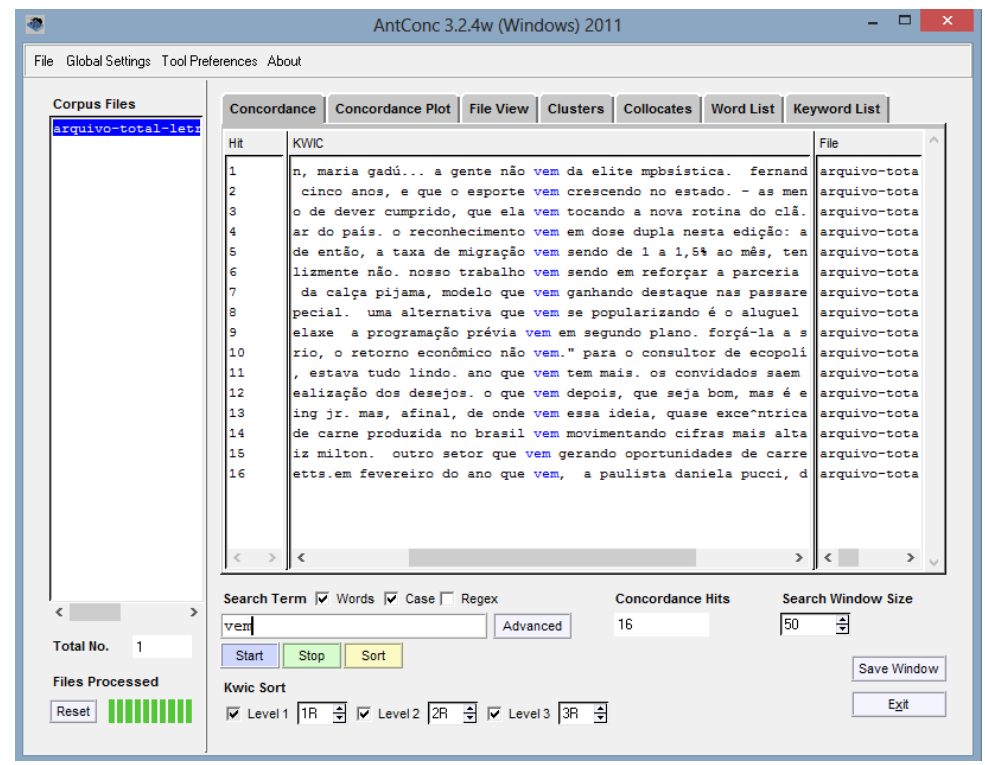

Figura14: Palavra e contexto linguístico

Assim sendo, depois de executadas as duas etapas, recolhemos os itens lexicais que compõem o corpus inicial e que serviram de suporte para as análises. 


\subsection{Metodologia de análise dos dados}

Após a seleção dos verbos, registramos as informações em fichas com o propósito de fornecer informações como:

a) tipo de verbo - se verbos de ação, que expressam uma atividade realizada por um sujeito agente; de processo, que expressam um evento ou sucessão de eventos que afetam um sujeito paciente ou experimentador; de ação-processo, que expressam uma ação realizada por um sujeito agente ou uma causação levada a efeito por um sujeito causativo, por exemplo; de estado, que expressam uma propriedade (estado, condição, situação) localizada no sujeito, de acordo com a classificação de Borba (2002) e Borba (2003, p. 222);

ii) número de complementos internos possíveis para os verbos, como sem complemento, com um complemento, com dois complementos e com três complementos, sempre que possível, agregados às preposições que os acompanham segundo a regência, com base em Borba (2002), Houaiss (2009) e Aulete (2014).

iii) definições semânticas, extraídas de Houaiss (2009) e do Aulete Digital (2014), por serem dicionários de grande circulação nacional. Utilizamos como documento auxiliar o Dicionário de Usos do Português do Brasil (2002), por apresentar informações sintático-semânticas registradas em uso efetivo da língua portuguesa no Brasil;

iv) uso real dos verbos de análise, de acordo com as definições fornecidas pelos dicionários selecionados, relacionadas aos 17 contextos foco desta pesquisa, que foram coletadas dos exemplos de uso registrados em sites de jornais, de revistas, de filmes brasileiros contemporâneos de grande bilheteria nacional ou de sites especializados no contexto em análise, por meio da ferramenta google.

O Dicionário de Uso do Português do Brasil (2002) foi selecionado por ser obra com base em um complexo banco de dados, elaborado a partir de um corpus da língua escrita em prosa no Brasil a partir de 1950, com um total de 77 milhões de ocorrências de palavras em textos de gêneros variados, conforme consta na apresentação do dicionário. O Dicionário Multilíngue de Regência Verbal - verbos preposicionados (2013) auxiliou-nos na inclusão 
de informações das preposições relacionadas aos verbos com complementos internos do tipo C2 e C3. Esta última obra é fruto da reflexão e da experiência de vários pesquisadores, professores e colabores que identificaram a necessidade de elaboração de uma obra que abordasse o uso das preposições de modo especial, segundo as autoras.

Ao ampliarmos as fontes de coleta de exemplos, incluindo filmes brasileiros e sites especializados de acordo com os contextos, entendemos ter, como isso, inserido mais variações da língua portuguesa falada no Brasil. Entretanto, em função do público-alvo, não iremos sobrecarregar o dicionário com usos muito particulares.

Destacamos que nem sempre todos os campos das fichas foram preenchidos, quer dizer, o vazio na ficha significa que o item não foi encontrado. Além dessas informações, a ficha foi elaborada para fornecer as marcas de uso como sentido formal ou informal. Apresentamos o modelo de ficha não preenchido e uma ficha preenchida a seguir: 


\begin{tabular}{|c|c|c|c|c|c|}
\hline \multicolumn{6}{|l|}{ VERBO } \\
\hline Tema & Definição & $\begin{array}{c}\text { Tipo de } \\
\text { verbo }\end{array}$ & Marca de uso & Exemplo & $\begin{array}{c}\text { Número de } \\
\text { complementos } \\
\text { e regência }\end{array}$ \\
\hline 1) Alimentação & & & & & \\
\hline $\begin{array}{l}\text { 2) Atividades comerciais } \\
\text { (compra e venda) }\end{array}$ & & & & & \\
\hline 3) Atividades domésticas & & & & & \\
\hline 4) Clima e tempo & & & & & \\
\hline 5) Crime e violência & & & & & \\
\hline 6) Educação & & & & & \\
\hline 7) Esportes & & & & & \\
\hline 8) Festas e festividades & & & & & \\
\hline 9) Lazer & & & & & \\
\hline 10) Moradia & & & & & \\
\hline 11) Profissão e trabalho & & & & & \\
\hline 12) Relações sociais & & & & & \\
\hline 13) Saúde e doenças & & & & & \\
\hline 14) Tabuísmo & & & & & \\
\hline 15) Trânsito e transportes & & & & & \\
\hline 16) Vestimentas e indumentárias & & & & & \\
\hline 17) Viagens e hospedagem & & & & & \\
\hline
\end{tabular}




\begin{tabular}{|c|c|c|c|c|c|}
\hline \multicolumn{6}{|l|}{ 01- JANTAR } \\
\hline Tema & Definição & Tipo de verbo & Marca de uso & Exemplo & $\begin{array}{c}\text { Número de } \\
\text { complementos } \\
\text { e Regência }\end{array}$ \\
\hline 1) Alimentação & tomar a refeição da noite & $\begin{array}{l}\text { Ação } \\
\text { [complemento } \\
\text { concreto] } \\
\text { [sem } \\
\text { complemento] }\end{array}$ & & $\begin{array}{l}\text { João jantou arroz e carne e verdura } \\
\text { (G1.globo) } \\
\text { Eles jantam com os amigos aos } \\
\text { sábados (adapt. Rev.CB }\end{array}$ & $\begin{array}{l}\text { Com complemento } \mathrm{Cl} \\
\text { Arroz, carne, verdura. } \\
\text { Sem preposição } \\
\text { Sem complemento } \mathrm{C0} \\
\text { Sem preposição } \\
\end{array}$ \\
\hline $\begin{array}{l}\text { 2) Atividades comerciais (compra e } \\
\text { venda) }\end{array}$ & & & & & \\
\hline 3) Atividades domésticas & & & & & \\
\hline 4) Clima e tempo & & & & & \\
\hline 5) Crime e violência & & & & & \\
\hline 6) Lazer & & & & & \\
\hline 7) Educação & & & & & \\
\hline 8) Esportes & $\begin{array}{l}\text { Passar para trás, derrotar o } \\
\text { adversário. }\end{array}$ & $\begin{array}{l}\text { Ação } \\
\text { [complemento } \\
\text { abstrato de ação] }\end{array}$ & Informal & $\begin{array}{l}\text { Walter, o melhor em campo, jantou } \\
\text { a zaga do Botafogo. } \\
\text { (Sgloboesporte) }\end{array}$ & $\begin{array}{l}\text { Com complemento } \mathrm{Cl} \\
\text { a zaga } \\
\text { Sem preposição } \\
\end{array}$ \\
\hline 9) Festas e festividades & & & & & \\
\hline 10) Moradia & & & & & \\
\hline 11) Profissão e trabalho & & & & & \\
\hline 12) Relações sociais & & & & & \\
\hline 13) Saúde e doenças & & & & & \\
\hline 14) Tabuísmo & & & & & \\
\hline 15) Trânsito e transportes & & & & & \\
\hline 16) Vestimentas e indumentárias & & & & & \\
\hline 17) Viagens e hospedagem & & & & & \\
\hline
\end{tabular}

Ficha para análise de verbos preenchida 
Com base nas informações contidas nas fichas e nas teorias de Lexicologia, de Lexicografia e da GDF, organizamos os dados em uma segunda etapa de análise. Destacamos que alteramos a nomenclatura dos complementos para ajustá-la à análise apresentada no capítulo 5 , referente à análise de dados. Assim sendo, o complemento tipo 1 - (C1) foi denominado no capítulo de análise desta tese de complemento externo. O complemento tipo 2 - (C2) foi denominado de complemento interno do verbo com característica de não apresentar preposição, sendo representado, doravante, por C1. O complemento tipo 3 - (C3) foi denominado de complemento interno do verbo com característica de apresentar preposição, sendo representado, doravante, por C2. Por fim, o complemento tipo 4 - (C4) foi denominado de segundo complemento interno com preposição, doravante, por $\mathbf{C 3}$ e, quando o verbo não apresentar complemento interno, será denominado sem complemento, $\mathbf{C O}$.

O verbo em análise está em negrito, o complemento externo está em itálico e os complementos internos estão sublinhados. As setas vermelhas indicam o tipo de verbo, se de ação, ação-processo, processo ou estado. As setas pretas e azuis indicam as especificidades dos complementos externo e interno, respectivamente.

Expomos a seguir um exemplo de análise referente aos dados que registram a ocorrência do verbo jantar e os diferentes significados. O item que representa o agente do enunciado foi alterado com a troca de um nome fictício.

Verbo de ação

12) João jantou arroz e carne e verdura (adaptado de G1.globo)

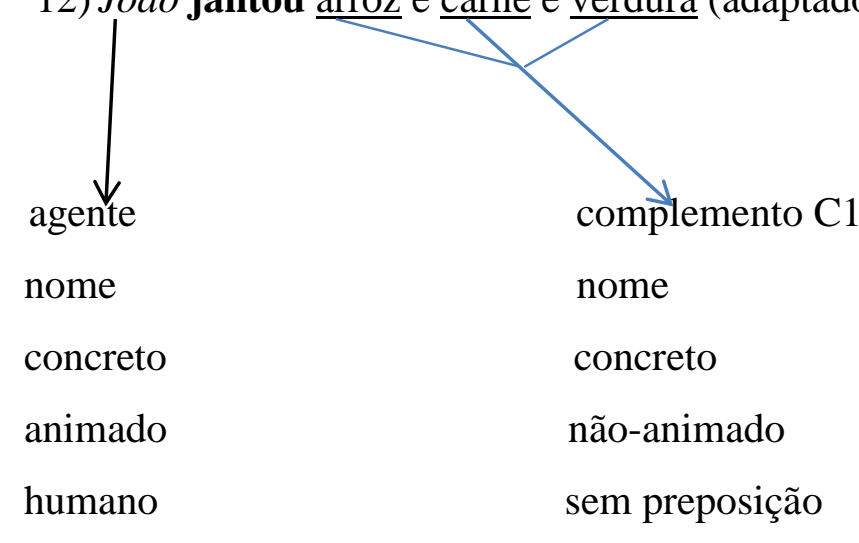

Significado do verbo jantar $\rightarrow$ tomar a refeição da noite (específico).

$\underline{\text { Arroz }}, \underline{\text { carne e verdura }}=$ complemento interno $(\mathrm{C} 1) \rightarrow$ nome, concreto, não-animado, sem preposição. 
João $=$ complemento externo $\rightarrow$ agente, nome, concreto, animado e humano.

Contexto situacional $\rightarrow$ alimentação.

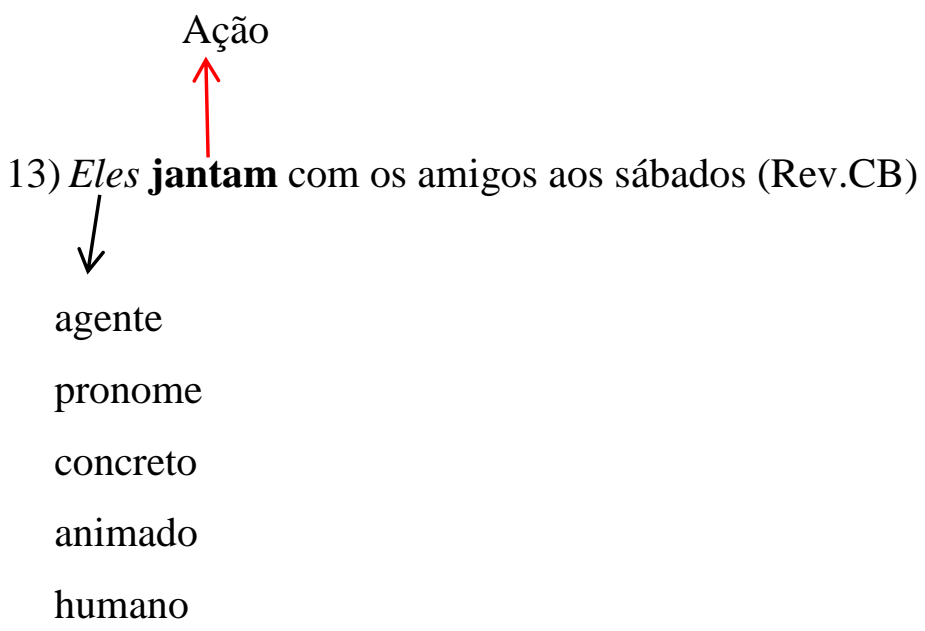

Significado do verbo jantar $\rightarrow$ tomar a refeição da noite (sentido genérico).

$\varnothing=$ sem complemento interno $(\mathrm{C} 0)$

Eles $=$ complemento externo $\rightarrow$ agente, pronome, concreto, animado e humano.

Contexto situacional $\rightarrow$ alimentação.

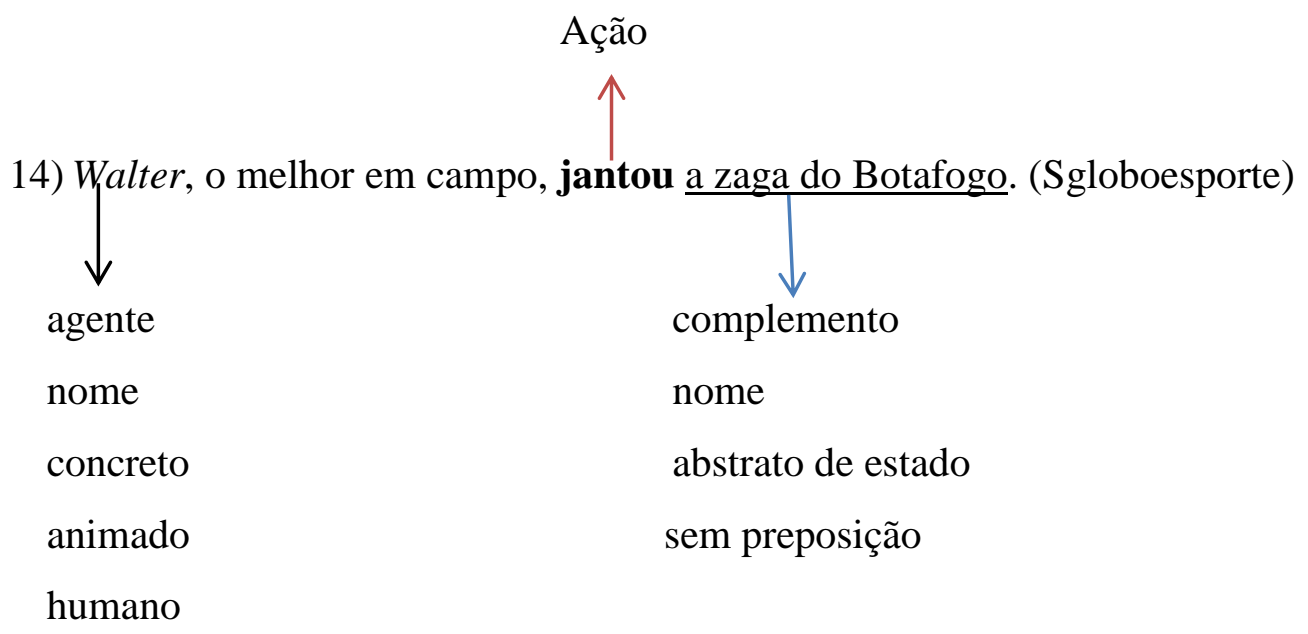

Significado do verbo jantar $\rightarrow$ passar para trás, derrotar o adversário com certa facilidade.

$\underline{\text { A zaga do Botafogo }}=$ complemento interno $(\mathrm{C} 1) \rightarrow$ nome, abstrato de estado.

Walter $=$ complemento externo $\rightarrow$ agente, nome, concreto, animado e humano.

Contexto situacional $\rightarrow$ esporte. 
Essa metodologia nos permitiu identificar significados distintos dos verbos, como a exemplo do verbo jantar, de acordo com cada ocorrência, em vista de cada enunciado representar uma única unidade conceptual dentro do contexto linguístico, situacional e cultural. Os lexemas João, jantar, arroz, carne e verdura, do enunciado (12); eles, jantam, amigos e sábado do enunciado (13) e Walter, melhor, campo, jantar, zaga e Botafogo, no enunciado (14), fornecem a descrição composicional de um estado de coisa ( $\mathrm{e}_{\mathrm{i}}$ ) e de ações, estados ou processos desempenhados por esses elementos, pois contêm um conjunto de características disponíveis no sistema linguístico virtual e, no contexto, ocorrem combinações necessárias para o significado contido em cada enunciado, conjugado com fatores como tempo, por exemplo, passado, e como lugar, por exemplo, campo de futebol, enunciado (14).

Observamos que o aspecto cultural atua na formação conceitual, desse modo, exerce influência na composição semântica, pois, normalmente, na cultura brasileira, jantar está associado a uma refeição de fácil digestão (excetuando as refeições de ocasiões especiais), por isso há a projeção desse aspecto semântico para o significado de jantar no enunciado (14), colaborando para o significado de passar para trás, vencer com facilidade.

Seguindo esse caminho, podemos constatar a interação do componente conceitual, do componente gramatical e do componente contextual, conforme descreve a GDF. Para tanto, observamos a organização do enunciado de acordo com as regras de distribuição dos lexemas na língua conforme as propriedades lexicais. Desse modo, a gramática da língua entra em ação, distribuindo os itens do enunciado, de acordo com a relação verbo-nome, associadas às intenções comunicativas e às situações em que os eventos comunicativos ocorrem.

$\mathrm{O}$ verbo jantar, ao atender a essas regras e às propriedades lexicais, exige um complemento externo, que normalmente tem como características ser agente, concreto, animado e humano. Além do complemento externo, o verbo jantar apresenta, como regra geral, argumento interno, que estamos registrando como complemento, com as seguintes características: nome, concreto, não-animado e sem preposição. Porém, no discurso, o falante atribui um complemento com característica de abstrato de estado, que no contexto situacional e cultural relativo à partida de futebol no Brasil, gera o significado de passar para trás, derrotar o adversário com facilidade e não o de ingerir alimento, tomar alimento, nutrir o corpo com refeição leve. A extensão de sentido ocorre a partir do aspecto refeição leve, que pressupõe fácil digestão. Sendo assim, derrotar o adversário, como o corpo digere uma refeição leve como o jantar, com facilidade. 
Desse modo, verificamos que o contexto linguístico necessita de outros elementos para que haja compreensão dos significados. No exemplo (14), o contexto físico, campo de futebol, e o contexto social, partida de campeonato importante para o esporte brasileiro, fornecem informações sobre o 'cenário' e a 'cena' do evento comunicativo. Assim, contexto linguístico, contexto físico, contexto social atuam em cooperação para a construção dos significados.

Neste sentido, o dicionário de aprendizagem de verbos do português do Brasil como segunda língua - Dicverb/PL2, como fonte de informações de língua e cultura para os aprendizes de PSL, oferecerá uma microestrutura que apresente, além das informações linguísticas, informações extralinguísticas para a aprendizagem dos verbos. A inclusão dos contextos situacionais sustenta-se por observarmos, segundo a metodologia adotada, que o conjunto de elementos linguísticos e extralinguísticos é fundamental para auxiliar o aprendiz, o que cooperará para a compreensão e para as produções de significado em conjunto com as estruturas sintáticas da língua portuguesa.

Assim, visamos descrever os verbos na perspectiva da associação do componente conceitual, do componente contextual, do componente gramatical e do componente de saída. Para isso, apresentaremos meios que forneçam significados ao usuário e que contribuam para o processo de aprendizagem da língua-alvo. O componente de saída será representado, em parte, pela transcrição fonética e pelo áudio do dicionário.

\subsubsection{O tratamento dos verbos quanto à polissemia e à homonímia}

As palavras relacionam-se e classificá-las é definir uma em oposição às outras, como no caso dos itens lexicais polissêmicos que se opõem aos itens lexicais homonímicos pela ambiguidade que surge. Para distinguir polissemia de homonímia, apresentamos alguns critérios que poderão atenuar a confusão semântica.

Normalmente, define-se homônimo como itens lexicais com significados diferentes, mas que possuem a forma gráfica ou a forma fonética semelhante a outro item lexical. Para Cançado (2005, p. 65), a homonímia "ocorre quando os sentidos da palavra dita ambígua não são relacionados semanticamente"; a autora afirma que existe uma diferença entre homonímia e polissemia tradicionalmente assumida pela literatura semântica, mais especificamente pela Lexicologia. Polissemia e homonímia são fenômenos que lidam com os vários sentidos para itens lexicais fonologicamente ou graficamente semelhantes, 
entretanto polissemia ocorre quando o item lexical apresenta significados que estão, de certo modo, relacionados.

Silva (1999), em seu estudo sobre a semântica do verbo deixar, discorre sobre o problema da polissemia e descreve a polissemia e a homonímia fazendo contrastes entre os conceitos. Com referência à homonímia, existe uma subclassificação em homófonos e homógrafos. Homógrafos são itens lexicais com significados distintos, porém com a mesma forma gráfica, como encosto (verbo p.p. do presente do indicativo) e encosto (substantivo). Homófonos são itens lexicais com significados distintos, porém com a mesma forma fônica, como coser e cozer. Quanto à classe gramatical, distingue-se homonímia perfeita ou absoluta e homonímia imperfeita. A homonímia perfeita resulta de significados distintos pertencerem à mesma classe gramatical, como selar (ação de pôr sela ou selim) e selar (ação de pôr selo). Já a homonímia imperfeita resulta de itens lexicais homófonos ou homográfos de classes gramaticais diferentes, como jantar (verbo) e jantar (substantivo).

A polissemia, ou significado múltiplo, é a denominação dada ao fenômeno que ocorre em itens lexicais que apresentam mais de um significado, mas que estão semanticamente relacionados, como tomarei um pouco do seu tempo e tomarei um copo de coca-cola. Henriques (2011, p.96) alerta para o fato de que, “apesar do campo minado da polissemia, é preciso reconhecer que ela serve como um fator de economia e de flexibilidade para o léxico". Representamos no esquema a seguir, simplificadamente, a distinção entre homonímia e polissemia.

\section{Homonímia}

Item lexical $\mathrm{X}=$ significado 1 + mesma forma gráfica ou fonética do item lexical $\mathrm{Y}$ Item lexical $\mathrm{Y}=$ significado $2+$ mesma forma gráfica ou fonética do item lexical $\mathrm{X}$

\section{$\underline{\text { Polissemia }}$}

Item lexical $Z=\left\{\begin{array}{c}\text { significado } 1 \\ \text { significado } 1^{\prime} \\ \text { significado } 1^{\prime \prime} \\ \text { significado } 1^{\mathrm{n}}\end{array}\right]+$ mesma forma gráfica e fonética do item lexical Z 
A fronteira entre homonímia e polissemia não é tão nítida, apesar de diversos estudos apresentarem esses fenômenos linguísticos sob os critérios adotados para distiguir itens lexicais com significados semelhantes ou não. Na maioria das vezes, recorre-se à etimologia do item lexical para resolver a questão, entretanto esse critério, às vezes, não soluciona o problema, porque, muitas vezes, as origens são dúvidosas. Por outro lado, consideramos que a etimologia é um caminho para a distinção entre polissemia e homonímia. Assim sendo, no Dicverb/PL2, recorreremos à distinção etimológica apresentada nos dicionários Houaiss (2009), Ferreira (2009) e Aulete (2014) para diferenciar palavras homônimas das polissêmicas, associando-as às pistas fornecidas pelos contextos de uso em que os itens ocorrem. Na estrutura do dicionário, os verbos homônimos terão entrada própria e os verbos polissêmicos terão seus significados distintos registrados na mesma entrada do item lexical, distribuídos entre os 17 contextos que são abordados no dicionário de verbos.

\subsection{Metodologia para a seleção de itens de composição da microestrutura do dicionário de PSL}

Ao ser constatada a carência de dicionários elaborados para a aprendizagem de Português do Brasil como Segunda Língua e ao tomar conhecimento do valor desse tipo de obra para os aprendizes de língua, decidimos propor um modelo de dicionário para aprendizes de segunda língua, com o rigor dos princípios da lexicográfica moderna, assentada na Linguística. Destaca Rey-Debove (1984, p. 45) que:

há duas maneiras de aprender uma língua: uma natural e outra artificial, o modo natural refere-se às tentativas que vão sendo aperfeiçoadas durante a comunicação que chegam a conhecimentos memorizados dessa língua (competência natural), como o da criança inserida no ambiente familiar, que demonstra um domínio perfeito da língua sem que se saiba descrevêla; modo artificial, em ambiente formal, com o auxílio de obras descritivas, conhecidas como indispensáveis e complementares: a gramática e o dicionário.

O que nos chama atenção nessa citação é a relevância do dicionário na aprendizagem de língua. Para Rey-Debove, escolher dicionários como ferramenta de aprendizagem é assumir que essas obras desempenham importante papel de lexicografia pedagógica. Como complemento às ideias da autora, adotamos os procedimentos metalexicográficos, que, segundo Faulstich (2001, p. 2): 
são de natureza durativa, porque analisam, sob o ponto de vista teórico, os conceitos básicos que servem à lexicografia, antes de estes serem, na prática, empregados na elaboração dos dicionários. Os estudos teóricos centram-se nos aspectos metodológicos e procuram responder à pergunta: como se faz ou como se deve fazer um dicionário? Esta pergunta é respondida pela pesquisa científica, que, na prática, investiga como são feitos os dicionários.

Para avaliar como são feitos os dicionários, escolhemos o Dicionário Larousse Inglês/Português-Português/Inglês, usado na aprendizagem da língua inglesa. Desse dicionário, recolhemos dados que foram organizados em fichas lexicográficas. O modelo de ficha adotado possui como base a Proposta metodológica para a elaboração de léxicos, dicionários e glossários e o Roteiro para avaliação de dicionários e glossários científicos e técnicos (FAULSTICH, 1996 e 2011). Desse modo, foram geradas duas fichas de análise para avaliação da macroestrutura e da microestrutura das obras selecionadas, que serviram de ponto de partida para a elaboração do Dicverb/PL2. Em complemento à análise sobre estrutura de dicionários, estudamos também estruturas do dicionário semibilíngue Password: English dictionaty for speakers of Portuguese, e do o dicionário Señas para la enseñanza de la lengua española para brasileiros, entre outros como apresentamos no Capítulo 4.

As decisões tomadas dizem respeito ao dicionário de aprendizagem, semibilíngue e informatizado. A proposta está organizada da seguinte forma: informações ortográficas, fonológicas, morfológicas, sintáticas, pragmáticas, e aspectos sociais relativos ao contexto brasileiro.

Vale observar o que Correia (2009, p. 40) diz acerca de dicionários de aprendizagem, que são obras "especialmente pensadas para um público que se encontra em situação de aprendizagem de língua, seja como língua materna, seja como língua segunda ou estrangeira". Além disso, esses dicionários seguem a nova tendência de elaboração e de divulgação de obras lexicográficas informatizadas por meio de ferramentas próprias, elaboradas por profissionais que desenvolvam software que viabilize a difusão das informações linguísticas e extralinguísticas. Atendendo essa tendência, o Dicionário de aprendizagem de verbos do português do Brasil como segunda língua será informatizado.

Os elementos de composição da macroestrutura e da microestrutura serão apresentados no Capítulo 6. 


\subsection{Síntese do capítulo}

O presente capítulo expôs o caminho metodológico percorrido durante a pesquisa. Procuramos demonstrar as escolhas feitas, expor os motivos que conduziram à escolha do corpus, os critérios de seleção do corpus, o tratamento dado ao corpus, à elaboração da proposta de modelo de dicionário de aprendizes de PSL. Assim sendo, a metodologia conduzirá os capítulos que seguem. 


\section{CAPÍTULO 4 - LEXICOGRAFIA PARA L2: ASPECTOS DA ESTRUTURA DE DICIONÁRIOS BILÍNGUES E SEMIBILÍNGUES}

Neste capítulo, serão expostos os aspectos da lexicografia portuguesa, com destaque para o desenvolvimento das obras bilíngues e semibilíngues, cuja finalidade é identificar os elementos de composição estritos, a saber: a macroestrutura e a microestrutura. Essa identificação nos permitirá estabelecer diretrizes para os elementos da estrutura do Dicionário de aprendizagem de verbos do português do Brasil como L2 - Dicverb/PL2, para que os componentes gramaticais e não-gramaticais sejam incluídos na proposta, de acordo com a função da obra e do público-alvo, para auxiliar a aprendizagem dos verbos da língua portuguesa. Desse modo, buscamos incluir na proposta o contexto como agente contribuidor para a significação.

\subsection{Breve percurso da lexicografia antiga à contemporânea}

O conhecimento relativo à produção de obras lexicográficas revela que os homens apresentavam preocupação em arquivar o léxico da língua. A prova disso são as listas de palavras com equivalentes em outras línguas produzidas pelos sumérios, acadianos e babilônios (FARIAS, 2007, p. 89), assim como os glossários produzidos pelos gregos e o Appendix Probi, obra dos latinos (BIDERMAN, 1984, p. 1). Essa obra latina refere-se à lista de palavras de caráter normativo, que visava à correção de palavras consideradas como "erros", apresentando os correspondentes "corretos" como em gyrus non girus ou avus non aus, conforme registra Ilari (1999, p.71).

As mudanças sociais e políticas da Idade Média, em que ocorre a formação de novos povos e a reorganização do Velho Mundo, originando as línguas neolatinas, geram gramáticas e dicionários bilíngues, em que o latim era uma das línguas focalizadas. Os glossários, em sua maioria, eram organizados segundo temas como agricultura, guerra, comércio, direito e religião, com vistas a favorecer a organização social, econômica e política da época. Desse período, citamos os manuscritos do Elementarium, de Papias (1050), considerado um arquétipo dos dicionários modernos, do Liber derivationum, de Hugucio de Pisa (fins do século XII), do Catholicon, de João Balbo (1286), apenas como ilustração (VERDELHO, 2002, p. 15). 
Entretanto, é na Idade Moderna que a lexicografia começa a ganhar consistência, a partir da sistematização dos vernáculos das línguas neolatinas em contraste com o latim, decorrência do surgimento dos estados nacionais, que reconhecem suas línguas autônomas, assim como a necessidade de compreender outras línguas para promover interação entre os povos. A influência renascentista conduziu à valorização do ser humano, que, por meio do desenvolvimento da razão e do pensamento crítico, reivindicou, além de outros, o direito de examinar os textos bíblicos, o que despertou o interesse em aprender o latim para atingir seus objetivos. Desse modo, os dicionários e as primeiras gramáticas são de caráter pedagógico, elaborados para que cada nação-estado emergente aprendesse sobre sua língua e aprendesse o latim, que está na base da formação das línguas neolatinas e que retinha em seu léxico o conhecimento de diversas áreas. Os primeiros dicionários desse período são os bilíngues, tais como o Castelhano-Latim Universal Vocabulario (1490), de Alonso de Palencia; os vocabulários Latino Español (1492) e Español Latino (1495), de Antônio Nebrija; Dictionarium Latino-Gallicum e Dictionnaire François-Latin (1539), de Robert Estienne; o Dictionarium latino-lusitanicum e lusitanico-latinum (1570), de Jerónimo Cardoso (1569), como afirmam Biderman (1984a, p. 2), Murakawa (2001, p. 153) e Verdelho (2002, p. 17).

Entre 1712 e 1721, na cidade de Coimbra, foram impressos, sucessivamente, os oito volumes que compõem o Vocabulário Portuguez Latino e, posteriormente, foram impressos dois volumes de suplemento, em 1727- 1728, do Padre Raphael Bluteau, que os ofereceu ao rei de Portugal D. João V. Rafael Bluteau, doutor em ciências teológicas, nascido em Londres, mas de família francesa, estudou em universidades da Itália e da França, foi padre da ordem de clérigos regulares teatino, fundada por São Caetano de Tiene. Essas experiências contribuíram para que o padre tivesse o conhecimento de outras línguas, além da sua língua $1-\mathrm{L} 1^{18}$.

A obra lexicográfica de Bluteau é fruto do período em que viveu em Portugal, do seu conhecimento linguístico, em virtude das línguas que falava, e de suas atividades oratórias, em que tinha contato direto com a comunidade local. Como estrangeiro em Portugal, precisou aprender a língua falada pelo povo da região e, assim, conseguir êxito em seus sermões. O Pe. Bluteau aprendeu o português de Portugal como segunda língua, por isso sua obra apresenta detalhamentos, de certo modo, desnecessários ao falante nativo da língua

\footnotetext{
${ }^{18}$ Os termos língua materna, primeira língua e língua 1 estão sendo utilizados nesta tese com o mesmo conceito, utilizados em oposição à língua estrangeira e à segunda língua.
} 
portuguesa, conforme alguns críticos da época descrevem, como Pedro José Fonseca da Academia das Ciências de Lisboa, cf. Diccionario da Lingoa Partugueza, 1793, registrado em Verdelho:

\begin{abstract}
O titulo deste mesmo Vocabulario, a redundancia da sua prolixa erudição, a falta de innumeraveis vocabulos Portuguezes, e de autoridades, que na maior parte das suas accepções qualifiquem os mesmos, que traz, finalmente a mà eleição dessas taes poucas autoridades sem critica nem graduação (...) hum sem conto de definições ou explicações de termos por vários modos defeituosas, muitas etymologias erradas ou pouco seguras, havendo outras certas ou mais provaveis, e não menos citações de Autores Portuguezes impropriamente allegadas, ou em confirmação de significado, para que não servem, ou pelo modo viciado, com que estão transcritas; além de outros defeitos assàs notaveis ainda naquillo mesmo que directamente toca à lingoa Portugueza. (Diccionario 1793, p. III apud VERDELHO, 2002, p. 23)
\end{abstract}

No entanto, o Vocabulario Portuguez Latino, elaborado sob uma perspectiva de descrição de L2, reflete a análise de um falante que não tinha a língua portuguesa como L1, e as experiências vividas pelo autor, “cujo imaginário está ligado a reis, monarcas, rainhas, princesas, batalhas, cavalheiros e igrejas, transmitindo a mentalidade de seu tempo" (MURAKAWA, 2001, p. 155), refletem alguns excessos de informações que poderiam ser relevantes a um falante de português como segunda língua. Entre outros aspectos, como destaca Verdelho (2002, p. 72), há a valorização da variedade usada pelos nobres e pelos bons escritores no Vocabulario.

O reconhecimento da obra é grande, faz do Vocabulario de Bluteau uma referência na produção lexicográfica. O dicionário de Bluteau motiva a elaboração do Dicionário da Língua Portuguesa, da autoria de Antônio de Moraes e Silva, publicado em 1789, em Portugal. Porém, somente na segunda edição, em 1813, a obra é consagrada a Morais, porque, na primeira edição, o próprio autor não reconhece sua autoria, registrando o dicionário como do Pe. Raphael Bluteau, mas reformado e acrescentado por Antônio de Morais e Silva.

Os fatores extralinguísticos como o Humanismo, as Grandes Navegações, a formação de novos Estados e o processo de cristianização foram os propulsores para movimentação da humanidade no mundo moderno e provocaram o estreitamento das relações internacionais. Assim sendo, há a proliferação de obras lexicográficas, que promovem o contato da língua portuguesa com outras línguas europeias, línguas africanas e línguas 
indígenas. Testemunham a favor dessa proliferação o Diccionario Español-Portuguez (1864), de Manoel do Canto e Castro Macarenhas Valdez e o Vocabulário na Língua Brasílica (séc. XVII). Este último, de autoria desconhecida, refere-se ao vocabulário português-tupi, dedicado aos ministros de altar, aos futuros ministros e a todos que se interessem pela história natural e a geografia do Brasil, conforme consta no prefácio da obra. Diferentemente do Vocabulário de Bluteau, o vocabulário na língua Brasílica não foi concebido como obra direcionada à aprendizagem de L2, visto que a intenção principal desse material foi estabelecer uma linha de contato entre os jesuítas e os índios na catequização.

Esse percurso da história da humanidade e as constantes mudanças favorecem nova fase da produção lexicográfica com expressão significativa para as obras pedagógicas, em que se destacam os dicionários bilíngues. Em dimensões extraordinárias, faz-se necessária a compreensão e a produção de textos de toda natureza, o que exige as obras lexicográficas mais refinadas. Além disso, a globalização insere os dicionários no mercado como bens de consumo. Consequentemente, há demanda para a produção de dicionários e de outras obras de referência em vista do público-alvo.

Nas últimas décadas, grandes edições chegam ao Brasil, o que possibilita que estudantes brasileiros aprendam línguas estrangeiras. Entretanto, Duran e Xatara (2007, p. 2) chamam atenção para o fato de que "os dicionários verdadeiramente pedagógicos disponíveis no Brasil são obras traduzidas ou adaptadas de empreendimentos lexicográficos estrangeiros e, por isso, nem sempre apresentam a melhor adequação para os brasileiros". Sobre obras dessa natureza, Tosqui (2002, p. 52), ao analisar alguns dicionários inglêsportuguês, afirma que, em muitos dos dicionários bilíngues, os equivalentes são "despejados na definição sem a menor contextualização, exemplificação, ou indicação das características sintáticas, semânticas e situação de emprego do item lexical em questão". Silva (2010, p. 340), ao fazer algumas reflexões sobre verbete dos dicionários bilíngues francês-português, registra alguns problemas como a inclusão da variedade brasileira do português, que não está bem resolvida, apresentando a perspectiva apenas do pesquisador europeu, assim como identificou problemas referentes à atualização de novos significados e à falta de sistematicidade das obras.

Apesar de todas as críticas, a produção lexicográfica no Brasil para estrangeiros residentes no país é deficiente, o que faz com que aprendizes recorram a obras elaboradas para brasileiros aprenderem uma língua estrangeira. Nosso interesse se volta para as 
necessidades de dicionários elaborados dentro de uma concepção de segunda língua, pois as especificidades entre o aprendiz de L2 e o aprendiz de LE são distintas.

Desse modo, as diretrizes para a elaboração de um dicionário de segunda língua (L2) respaldam-se na análise de características típicas dos dicionários bilíngues e semibilíngues. Em continuidade, será apresentado em um breve panorama da tipologia lexicográfica.

\subsection{A tipologia das obras lexicográficas: dicionários bilíngues e dicionários semibilíngues}

A história da lexicografia demonstra que a classificação das obras muda à medida que surgem novos autores com perspectivas diferentes sobre o fazer lexicográfico. Assim sendo, apresentamos, a seguir, aspectos para a tipologia lexicográfica que considera os seguintes critérios: formato e quantidade de entradas.

\subsubsection{Quanto ao formato}

O formato é um critério para classificar obras lexicográficas de acordo com a praticidade do dicionário. Nas obras impressas, são observados as dimensões, a quantidade de volumes e o número de páginas. De acordo com as dimensões, os dicionários impressos, com único volume, são classificados como: minidicionário $(17 \times 12 \mathrm{~cm})$; pequeno $(20 \times 13$ $\mathrm{cm})$; médio $(21 \times 15 \mathrm{~cm})$ ou grande $(28 \times 21 \mathrm{~cm})$. A quantidade de páginas entre obras de mesma classificação apresenta variação de acordo com o tipo da fonte e a quantidade de informações contidas no dicionário. Essa classificação considera a base física para registrar as informações lexicográficas, o suporte impresso.

Atualmente, inclui-se o formato informatizado, em suporte CD-Rom, DVD-Rom, pen drive ou em sites da internet. Vilarinho (2013, p. 53) descreve o dicionário informatizado como "concebido de modo que seja organizado e lido em máquina com base na programação feita pelo homem". Com referência ao formato dos dicionários informatizados, as características do suporte conduzem-nos a considerar aspectos diferentes do formato impresso, porque avaliam-se a compatibilidade do formato do dicionário com os dispositivos de acesso e o modo de armazenamento. Assim, se o dicionário estiver disponível apenas em CD-Rom, não poderá ser acessado por tablets. 
Correia (2009, p. 34) informa que existem dicionários informatizados que são “concebidos para serem usados por máquinas, isto é, para servirem de base a sistemas diversos de processamento de língua natural (PNL) e os que são organizados para serem usados por pessoas". Referente aos concebidos para pessoas, as obras informatizadas se subdividem em on-line e eletrônicas. Vilarinho (2013, p. 54) descreve que os dicionários informatizados diferenciam-se do seguinte modo: "os on-line estão disponibilizados na internet, para consulta via rede, e os eletrônicos estão disponibilizados em CD-ROM, DVDROM, ou aplicativos em dispositivos móveis, do tipo smartphones, computadores, tablets".

É de conhecimento que os avanços tecnológicos proporcionam vantagens às obras informatizadas frente às impressas. O sistema de busca, o sistema de ligações entre os conteúdos do dicionário, a audição da pronúncia das palavras, as inclusões de vídeos, além de outros, diferenciam o dicionário informatizado do impresso, em vista da modernidade. Ainda sobre as diferenças entre os dicionários impressos e os informatizados, é preciso dizer que "o armazenamento, o acesso e a apresentação das informações lexicográficas passam a ser encarados como processos relativamente independentes, ao contrário do que ocorre na mídia impressa" (DURAN e XATARA, 2004. p. 210). Portanto, ao analisarmos o formato impresso e o informatizado, optamos pela elaboração de um dicionário informatizado.

\subsubsection{Quanto à quantidade de entradas}

A quantidade de entradas depende do tamanho e da finalidade do dicionário. Carvalho (2001, p. 47), em seu trabalho sobre dicionários bilíngues, faz a seguinte distinção: dicionário de bolso, médio e grande. Os dicionários de bolso, também chamados de pequenos, são aqueles que contêm até 40.000 entradas; os que contêm entre 50.000 e 80.000 entradas são os de médio porte; os que contêm acima de 80.000 entradas são os dicionários grandes. Em vista de a quantidade de publicações de dicionários semibilíngues ainda ser reduzida, não apresentaremos classificação para essas obras quanto ao número de entradas. Ressaltamos que, entre os três dicionários semibilíngues pesquisados, concebidos para brasileiros, apenas o Señas: diccionario para la enseñanza de la lengua española para brasileños registra o número de entradas: 22.000 .

Biderman (1984a, 2001a), ao avaliar os dicionários monolíngues, afirma que a quantidade de entradas está relacionada ao público-alvo da obra e classifica os dicionários que contêm 5.000 entradas, aproximadamente, como de pequeno porte, como infantil ou 
básico. Os dicionários que contêm entre 10.000 e 30.000 são classificados como médio, correspondendo aos escolares. A pesquisadora também classifica como dicionário de tamanho médio os que contêm entre 50.000 e 70.000 entradas e que são destinados ao grande público, denominando-os de dicionários padrão, e os dicionários que contêm entre 100.000 e 400.000 entradas como tesouro lexical.

A classificação quanto ao número de entradas apresenta alguns problemas, porque a contabilização dessas entradas varia, a depender do modo como a editora conta cada acepção de uma palavra polissêmica (HAENSCH, 1982, p. 27; CORREIA, 2009, p. 33).

Em relação à quantidade de entradas, pesquisas recentes têm priorizado o aspecto qualitativo, ao analisar o tipo de informação que deve ser registrada no dicionário. Como exemplo disso, identificamos o Dicionário multilíngue de regência verbal: verbos preposicionados (2013), de Xatara, Zavaglia e Silva, o qual contém 1148 entradas, quantidade que não se inclui nas classificações apresentadas, porque as informações são estritamente gramaticais sobre o uso das preposições, de acordo com a regência do verbo, o que facilita a aprendizagem da língua estrangeira por brasileiros.

Porém esse quantitativo pode mudar, a depender do conteúdo da obra e do avanço tecnológico que permite novas configurações que aumentam a capacidade de armazenar informações. Assim, a denominação de pequeno, médio e grande para dicionários informatizados não deve seguir os padrões dos dicionários impressos. Em vista disso, a indicação de quantidade de entrada é uma estimativa. Essas observações e os estudos sobre elaboração de dicionários, com base na finalidade e no público-alvo possibilitam a inclusão de 1000 entradas no Dicverb/PL2.

\subsection{Organização da estrutura de dicionários}

A estrutura de um dicionário normalmente está dividida em partes: introdução, corpo do dicionário e anexos. Essas partes são denominadas de macroestrutura, conforme demonstra Heansch (1997, p. 39):

La macroestructura es la ordenación del conjunto de los materiales que forman el cuerpo de um diccionario (por ej. orden alfabético u orden sistemático), conjuntamente con el prólogo o prefacio, a veces una introducción fonética y gramatical, las instrucciones para el usuário y los 
posibles anexos (glossários nombres geográficos, listas de abreviaturas y siglas, glosarios de nombres de pila, etc. $)^{19}$

Cada uma dessas partes é elaborada para fornecer informações que conduzam o consulente a utilizar o conteúdo lexicográfico de acordo com o interesse dele.

A introdução contém o prólogo ou prefácio, explicações e instruções sobre o uso do dicionário, lista de abreviaturas e símbolos, número de entradas, informações sobre a pronúncia das palavras, resumo de regras ortográficas, paradigma de conjugação verbal. Cabe à introdução expor a finalidade da obra, o público para o qual se destina, as fontes utilizadas para compor a obra, $\mathrm{o}(\mathrm{s})$ autor(es) e a equipe que o elaborou. O corpo do dicionário refere-se à parte que contém o conjunto do léxico registrado. No caso dos impressos, pode estar em único volume ou mais.

Os anexos, normalmente, contêm informações de cunho enciclopédico, como mapas, nomes de países com os respectivos gentílicos, sistema monetário, lista de números ordinais e cardinais, gramática sucinta da língua, normalmente localizados nas últimas páginas da obra. Nos dicionários bilíngues ou semibilíngues, há quadros temáticos ilustrados. A localização dessas partes nos dicionários informatizados não obedece à mesma ordem dos dicionários impressos, o leiaute é diversificado.

Em nossa pesquisa, avaliamos a macroestrutura e a microestrutura de dois dicionários bilíngues e de três dicionários semibilíngues, a saber: Dicionário Larousse Inglês/Português-Português/Inglês (2009), Michaelis: dicionário prático inglês (2009); SEÑAS: dicionário para la enseñanza de la lengua española para brasileños (2006), Password: K dictionaries: English dictionary for speakers of Portuguese (2010) e Palavrachave: dicionário semibilíngue para brasileiros: francês (2011). E, selecionamos uma obra bilíngue, o Dicionário Larousse Inglês/Português-Português/Inglês (2009), e uma obra semibilíngue, SEÑAS: dicionário para la enseñanza de la lengua española para brasileños (2006) para demonstrar a análise da macroestrutura de dicionários nesta pesquisa. Esses dicionários, conforme exposto nos respectivos prefácios, possuem como público-alvo estudantes brasileiros.

\footnotetext{
${ }^{19}$ A macroestrutura é a ordenação do conjunto dos elementos que compõe o corpo de um dicionário (por exemplo a ordem alfabética ou a ordem sistemática), em conjunto com o prólogo ou prefácio, às vezes apresenta uma introdução fonética e gramatical, as instruções de uso e os anexos (glossários de nomes geográficos, lista de abreviaturas e siglas, glossários de apelidos etc.)
} 


\subsubsection{A macroestrutura dos dicionários}

Um dos meios de compreender um dicionário é pela composição da macroestrutura da obra. Na nossa pesquisa vamos aplicar a lexicográfica (FAULSTICH, 2001, com adaptações) que nos possibilita avaliar um dicionário bilíngue e um dicionário semibilíngue selecionados. A ficha servirá de base para nossos comentários.

Tabela 1: Ficha lexicográfica do dicionário bilíngue Larousse (2009)

\section{adaptada de Faulstich (2001)}

\begin{tabular}{|c|c|c|}
\hline \multicolumn{3}{|l|}{ Ficha 01} \\
\hline \multicolumn{3}{|c|}{$\begin{array}{l}\text { Título: Dicionário Larousse Inglês/Português . Português/Inglês: essenc } \\
\text { Autor: Larousse Editorial } \\
\text { Coordenador editorial - José A. Gálvez } \\
\text { Consultoria lexicográfica e atualização ortográfica: Thereza Pozzoli } \\
\text { Editora: Larousse do Brasil } \\
\text { Edição: } 2^{\text {a } e d i c ̧ a ̃ o ~} \\
\text { Data: } 2009 \\
\text { Local de publicação: São Paulo }\end{array}$} \\
\hline \multicolumn{3}{|l|}{ Sobre o autor } \\
\hline $\begin{array}{l}\text { 1.1. Trata-se de pessoa } \\
\text { reconhecida na área de } \\
\text { dicionarística ou de } \\
\text { terminologia? }\end{array}$ & \multicolumn{2}{|c|}{$\begin{array}{l}\text { A obra não apresenta autores. Atribui a autoria à instituição Larousse } \\
\text { Editorial e apresenta o coordenador editorial, José A. Gálvez, e o consultor } \\
\text { lexicográfico e ortográfico, Thereza Pozzoli. }\end{array}$} \\
\hline $\begin{array}{l}\text { 1.2. Fez parte de grupo de } \\
\text { pesquisa da área de } \\
\text { dicionarística ou de } \\
\text { terminologia? }\end{array}$ & \multicolumn{2}{|l|}{ Não. } \\
\hline $\begin{array}{l}\text { 1.3. Qual a formação } \\
\text { acadêmica do autor } \\
\text { principal e dos participantes } \\
\text { do } \\
\text { grupo de pesquisa? }\end{array}$ & \multicolumn{2}{|l|}{ Não se aplica. } \\
\hline $\begin{array}{l}\text { 1.4. Qual a profissão } \\
\text { exercida na época da } \\
\text { publicação da obra em } \\
\text { análise? }\end{array}$ & \multicolumn{2}{|l|}{ Não se aplica. } \\
\hline \multicolumn{3}{|c|}{ 2. Sobre a apresentação da obra } \\
\hline \multirow[t]{3}{*}{$\begin{array}{l}\text { 2.1. Há introdução na qual } \\
\text { apareçam claramente? }\end{array}$} & a) os objetivos da obra? & $\begin{array}{l}\text { Visa, principalmente, à compreensão e à } \\
\text { produção de textos escritos. Esta obra } \\
\text { soluciona de forma prática as dúvidas com } \\
\text { que nos defrontamos durante a leitura ou na } \\
\text { hora de escrever um texto em inglês, desde } \\
\text { artigos de jornais até obras literárias. }\end{array}$ \\
\hline & $\begin{array}{l}\text { b) o público para o qual o } \\
\text { conteúdo se dirige? }\end{array}$ & $\begin{array}{l}\text { A obra é destinada a estudantes (em } \\
\text { aprendizagem formal ou informal) da língua } \\
\text { inglesa, do nível básico ao nível } \\
\text { intermediário, profissionais em geral, turistas } \\
\text { e leitores que já estão no mercado de trabalho. }\end{array}$ \\
\hline & $\begin{array}{l}\text { c) as informações sobre } \\
\text { como consultar o dicionário } \\
\text { ou vocabulário? }\end{array}$ & $\begin{array}{l}\text { Há uma seção do dicionário nomeada: como } \\
\text { usar este dicionário, porém esta seção } \\
\text { contém somente a lista de abreviaturas, a lista } \\
\text { de transcrição fonética em português e em }\end{array}$ \\
\hline
\end{tabular}




\begin{tabular}{|c|c|c|}
\hline & & $\begin{array}{l}\text { inglês e informações sobre a disposição das } \\
\text { palavras compostas da língua inglesa no } \\
\text { dicionário. Não há instruções de como } \\
\text { consultar ou usar o dicionário. }\end{array}$ \\
\hline & $\begin{array}{l}\text { d) referências à bibliografia } \\
\text { de onde foi extraído o } \\
\text { corpus? }\end{array}$ & $\begin{array}{l}\text { Não há informações que indiquem de onde o } \\
\text { corpus foi extraído. Provavelmente, isso } \\
\text { ocorre por ser uma obra com a marca } \\
\text { Larousse, deixando implícito que há um } \\
\text { corpus disponível para os dicionários } \\
\text { Larousse. }\end{array}$ \\
\hline $\begin{array}{l}\text { 2.2. Há bibliografia de } \\
\text { consulta justificada pelo } \\
\text { autor? }\end{array}$ & \multicolumn{2}{|r|}{ 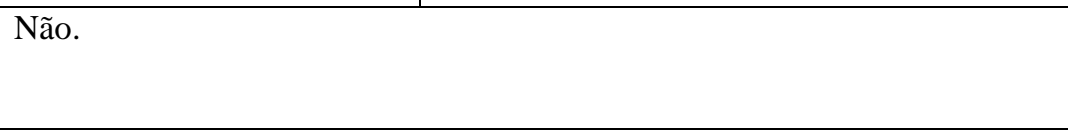 } \\
\hline \multicolumn{3}{|c|}{ 3. Sobre a apresentação material da obra } \\
\hline $\begin{array}{l}\text { 3.1. Há prefácio redigido } \\
\text { por personalidade } \\
\text { reconhecida na área de } \\
\text { dicionarstica? }\end{array}$ & \multicolumn{2}{|c|}{ A autoria do prefácio é atribuída à Editora. } \\
\hline $\begin{array}{l}\text { 3.2. A família tipográfica } \\
\text { empregada é adequada à } \\
\text { faixa etária do usuário? }\end{array}$ & \multicolumn{2}{|c|}{$\begin{array}{l}\text { A fonte de tamanho } 8 \text { é utilizada na obra, com espaçamento simples entre as } \\
\text { linhas (1.0), na cor preta, sendo as entradas em negrito. As abreviaturas são } \\
\text { em itálico ou em letras maiúsculas. As abreviaturas que representam as } \\
\text { categorias gramaticais encontram-se em itálico e as abreviaturas que } \\
\text { representam áreas especializadas, como matemática, educação, medicina, } \\
\text { estão em letras maiúsculas, apropriada ao público-alvo. }\end{array}$} \\
\hline $\begin{array}{l}\text { 3.3. As ilustrações, se } \\
\text { houver, estão adequadas à } \\
\text { microestrutura } \\
\text { informacional? }\end{array}$ & \multicolumn{2}{|l|}{ A obra não traz ilustrações. } \\
\hline $\begin{array}{l}\text { 3.4. A utilização de negrito, } \\
\text { de itálico e de outros } \\
\text { recursos gráficos está de } \\
\text { acordo com o equilíbrio } \\
\text { visual da obra }\end{array}$ & \multicolumn{2}{|c|}{$\begin{array}{l}\text { Há equilíbrio visual em relação ao uso de itálico e de negrito, porém há } \\
\text { excesso de uso de símbolos no corpo do verbete. }\end{array}$} \\
\hline 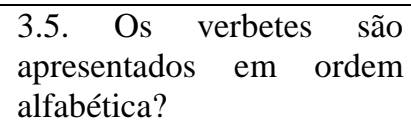 & \multicolumn{2}{|c|}{$\begin{array}{l}\text { Os verbetes estão distribuídos em ordem alfabética, inclusive as palavras } \\
\text { compostas (expressão idiomática), as quais receberam entrada própria. }\end{array}$} \\
\hline $\begin{array}{l}\text { 3.6. A obra contempla uma } \\
\text { só língua? Mais de uma? }\end{array}$ & \multicolumn{2}{|c|}{$\begin{array}{l}\text { A obra é bilíngue: inglês/português-português/inglês, portanto contempla } \\
\text { duas línguas. }\end{array}$} \\
\hline $\begin{array}{l}\text { 3.7. O formato do } \\
\text { dicionário ou vocabulário } \\
\text { permite manuseio prático e } \\
\text { fácil? }\end{array}$ & \multicolumn{2}{|c|}{$\begin{array}{l}\text { Quanto ao formato, a obra é em suporte de papel, possui dimensões: } 21 \mathrm{~cm} \\
\text { de altura, } 14 \mathrm{~cm} \text { de largura e } 3 \mathrm{~cm} \text { de espessura. Enquadra-se entre os } \\
\text { dicionários de médio porte. Contém } 350 \text { páginas. Essas proporções e a } \\
\text { quantidade de páginas atribuem praticidade ao dicionário, inclusive para } \\
\text { transportá-lo. }\end{array}$} \\
\hline $\begin{array}{l}\text { 3.8. A obra está editada em } \\
\text { suporte informatizado? }\end{array}$ & \multicolumn{2}{|l|}{ A obra é impressa. } \\
\hline $\begin{array}{l}\text { 3.9. A qualidade do } \\
\text { acabamento garante a sua } \\
\text { durabilidade? }\end{array}$ & \multicolumn{2}{|c|}{ A qualidade do material segue os padrões atuais para livros pedagógicos. } \\
\hline $\begin{array}{l}3.10 \text {. O sistema de } \\
\text { abreviações e de símbolos } \\
\text { aparece corretamente no } \\
\text { corpo do texto? }\end{array}$ & \multicolumn{2}{|c|}{$\begin{array}{l}\text { As abreviaturas aparecem corretamente. Porém, quanto aos símbolos, não há } \\
\text { descrição do que representam na introdução do dicionário. Desse modo, o } \\
\text { consulente que não é familiarizado com obras lexicográficas terá } \\
\text { dificuldades em consultar a obra, pois terá de deduzir o que cada símbolo } \\
\text { representa }(\sim<D)\end{array}$} \\
\hline $\begin{array}{l}\text { 3.11. A obra possui ampla } \\
\text { divulgação? }\end{array}$ & \multicolumn{2}{|c|}{$\begin{array}{l}\text { É uma obra divulgada em sites da internet, nas livrarias e usado em escolas } \\
\text { e cursos de línguas. }\end{array}$} \\
\hline
\end{tabular}




\begin{tabular}{|c|c|c|}
\hline \multicolumn{3}{|l|}{ 4. Sobre o conteúdo } \\
\hline $\begin{array}{l}\text { 4.1. As entradas cobrem de } \\
\text { maneira exaustiva a língua } \\
\text { oral e escrita, inclusive } \\
\text { neologismos, } \\
\text { derivadas, etc.? }\end{array}$ & \multicolumn{2}{|c|}{$\begin{array}{l}\text { A contracapa informa que o dicionário é atualizado; contém vocabulário } \\
\text { atualizado e abrangente; expressões idiomáticas e locucõos mas não } \\
\text { menciona se é exaustivo ou não. Considerando as dimensões e o público- } \\
\text { alvo, deduz-se que não é exaustivo. }\end{array}$} \\
\hline \multirow[t]{17}{*}{$\begin{array}{lcc}4.2 . & \text { Os } & \text { verbetes } \\
\text { apresentam? } & \end{array}$} & a) categoria gramatical? & $\begin{array}{l}\text { Sim, aparece em forma de abreviação e em } \\
\text { itálico, por exemplo, adj (para adjetivo). }\end{array}$ \\
\hline & b) gênero? & $\begin{array}{l}\text { Sim, aparece em forma de abreviação e em } \\
\text { itálico, por exemplo, } f \text { (para substantivo } \\
\text { feminino). }\end{array}$ \\
\hline & c) sinonímia? & Não. \\
\hline & d) variante(s) da entrada? & Não. \\
\hline & e) variante(s) da definição? & Não. \\
\hline & $\begin{array}{l}\text { f) existem critérios para } \\
\text { distinguir homonímia de } \\
\text { polissemia? Quais? }\end{array}$ & $\begin{array}{l}\text { Esse critério não é descrito na parte } \\
\text { introdutória do dicionário, mas, ao observar } \\
\text { os verbetes, notamos que a polissemia } \\
\text { localiza-se como subdivisão da entrada. Por } \\
\text { exemplo: ask [a:sk] } \diamond_{v t}-1 \text {. [question] } \\
\text { perguntar }-2 \text {. [enquire] perguntar }-3 \text {. [request] } \\
\text { pedir -4. [invite] convidar }\end{array}$ \\
\hline & $\begin{array}{l}\text { g) há emprego de marcas de } \\
\text { uso? Como se classificam? }\end{array}$ & $\begin{array}{l}\text { Sim, são classificadas como vulg (vulgar), pej } \\
\text { (pejorativo), fml (formal) inf (familiar ou } \\
\text { informal na parte inglês-português) e também } \\
\text { fam (familiar ou informal na parte português- } \\
\text { inglês). }\end{array}$ \\
\hline & $\begin{array}{l}\text { h) indicação de área ou } \\
\text { subárea de especialidade? }\end{array}$ & $\begin{array}{l}\text { Sim, existem marcas de área de especialidade } \\
\text { como: MED (medicina), INFORM } \\
\text { (informática). }\end{array}$ \\
\hline & $\begin{array}{l}\text { i) contexto? (exemplo ou } \\
\text { abonação?) }\end{array}$ & $\begin{array}{l}\text { O uso de exemplos não está em todos os } \\
\text { verbetes. Na introdução não há explicação } \\
\text { para o critério de inclusão ou não dos } \\
\text { exemplos. Quando há exemplos, a } \\
\text { apresentação é simplificada e reduzida, por } \\
\text { exemplo, to make a (para exemplificar o } \\
\text { uso de point) }\end{array}$ \\
\hline & j) equivalente(s)? & Sim. \\
\hline & k) formação da palavra? & Não. \\
\hline & 1) indicação de pronúncia? & $\begin{array}{l}\text { Sim, na introdução há a descrição dos } \\
\text { símbolos utilizados na transcrição fonética. }\end{array}$ \\
\hline & m) origem? & Não. \\
\hline & o) divisão silábica? & Não. \\
\hline & $\begin{array}{l}\text { q) remissivas úteis entre } \\
\text { conceitos? }\end{array}$ & $\begin{array}{l}\text { Sim, apresenta sistema de remissivas, por } \\
\text { exemplo, [Ver fazer no lado Português- } \\
\text { Inglês do dicionário] no final do verbete } \\
\text { make. }\end{array}$ \\
\hline & r) fontes? & Não apresenta. \\
\hline & s) notas? & $\begin{array}{l}\text { Apresenta algumas notas explicativas de uso } \\
\text { de algumas palavras, por exemplo [Ao se } \\
\text { empregar half como substantivo, não é } \\
\text { necessário o artigo (I can't eat all of that }- \\
\text { just give me half não posso comer tudo isso }\end{array}$ \\
\hline
\end{tabular}




\begin{tabular}{|l|l|l|}
\hline & & $\begin{array}{l}\text { - dê-me só a metade)], no final do verbete } \\
\text { half. Mas não há critério explícito para a } \\
\text { existência das notas. }\end{array}$ \\
\hline $\begin{array}{l}\text { 4.3. A definição é é } \\
\text { constituída de um um } \\
\text { enunciado e/ou de uma só } \\
\text { frase? }\end{array}$ & $\begin{array}{l}\text { Não há definição constituída por enunciados ou frases. Há somente o sistema } \\
\text { de inclusão de correlatos lexicais entre línguas. }\end{array}$ \\
\hline $\begin{array}{l}\text { 4.4. A definição leva em } \\
\text { conta o nível de discurso do } \\
\text { usuário? }\end{array}$ & Não se aplica. \\
\hline
\end{tabular}

Esse dicionário contém a maioria dos elementos que caracteriza uma obra classificada como bilíngue. Segue os padrões internacionais de catalogação para publicação, por isso, informa o título, o autor, o coordenador editorial, a consultoria lexicográfica (responsável pela atualização ortográfica), a editora, a data e local da publicação. No entanto, apesar de a autoria ser atribuída à renomada instituição Larousse, a consultoria lexicográfica foi realizada por pessoa não reconhecida no âmbito da Lexicologia e da Lexicografia. Fato que pode estar relacionado à ocorrência de equívocos nesse dicionário.

Na introdução são identificados o sumário, a apresentação da obra, o objetivo, o público-alvo, a quantidade de entradas, a lista de abreviaturas, a quantidade de entrada, as informações sobre a transcrição fonética para o registro das pronúncias. Com referência ao público-alvo, há generalização do perfil dos usuários. O dicionário é indicado a estudantes (em aprendizagem formal ou informal), do nível básico ao nível intermediário, profissionais em geral, turistas e leitores que já estão no mercado de trabalho. A inclusão de perfis distintos na mesma obra traz problemas quanto à seleção de conteúdo do dicionário, pois pode conter informações redundantes para uma parte e pode excluir informações relevantes para outra parte dos usuários.

Quanto à quantidade de entradas, na contracapa, há o registro da existência de mais de 55 mil acepções e 80 mil traduções. No entanto, a apresentação registra "com mais de 55 mil palavras e expressões e 80 mil traduções", a oscilação entre os termos não deixa claro o número de entradas existente nesse dicionário. Essa oscilação corrobora o problema descrito por Haensch (1982, p. 27) e Correia (2009, p. 33) sobre a contabilização do número de entradas, como apresentamos anteriormente.

Quanto à instrução de uso, há na obra uma seção intitulada Como usar este dicionário, porém não há instruções de como usar a obra, apenas estão registrados quadro de abreviaturas, indicação de como estão registradas as palavras compostas e quadro de transcrição fonética. Chamamos atenção para o fato de que as informações de como utilizar 
o dicionário são essenciais, pois, nessa parte, o lexicógrafo instrui o usuário a utilizar do melhor modo os recursos disponíveis no dicionário para facilitar a busca e a compreensão do conteúdo.

Acerca das marcações de uso, o dicionário Larousse utiliza símbolos no corpo da obra, mas não há nenhuma referência sobre o significado desses símbolos, cabendo ao aprendiz deduzi-los. É sabido que a inserção de símbolos em dicionários exige critérios, pois o excesso pode dificultar a leitura do verbete, em vista de exigir do usuário dois processos de decodificação, a dos símbolos utilizados no dicionário e a da língua em aprendizagem.

Os anexos, nomeados em algumas obras de apêndices, contêm a gramática sucinta da língua, a lista de verbos irregulares, a lista de números ordinais e cardinais, a lista de nomes de países grafados em português e em inglês e os respectivos gentílicos. Essas informações são de caráter enciclopédico.

Segundo a análise da macroestrutura do Dicionário Larousse inglêsportuguês/português-inglês: essencial, por meio da ficha lexicográfica, apresentamos um exemplar de dicionário com elementos característicos da classe dos bilíngues. Identificamos problemas estruturais nesse dicionário que podem ser consequência das adaptações de obras internacionais. Assim sendo, a avaliação desse dicionário auxiliou-nos a identificar como devem ser elaborados alguns elementos estruturais para que o usuário seja beneficiado de modo eficiente. Essa análise nos permitiu verificar que obras bilíngues elaboradas para brasileiros não oferecem informações relevantes para os aprendizes de PSL, pois não há elementos na macroestrutura que abordem aspectos da língua portuguesa.

A seguir, apresentamos aspectos do dicionário semibilíngue SEÑAS (2006), por meio da ficha lexicográfica de Faulstich (2001) 


\section{Tabela 2: Ficha lexicográfica do dicionário semibilíngue SEÑAS (2006) adaptada de Faulstich (2001)}

\begin{tabular}{|c|c|c|}
\hline \multicolumn{3}{|l|}{ Ficha 02} \\
\hline \multicolumn{3}{|c|}{$\begin{array}{l}\text { Título: SEÑAS: dicionário para la enseñanza de la lengua española para brasileños } \\
\text { Autor: Universidade de Alcalá de Henares. Departamento de Filologia. } \\
\text { Coordenador de tradução: Monica Stahel } \\
\text { Tradução: Eduardo Brandão e Claudia Berliner } \\
\text { Editora: Martins Fontes } \\
\text { Edição: } 4^{\text {a }} \text { edição } \\
\text { Data: } 2006 \\
\text { Local de publicação: São Paulo }\end{array}$} \\
\hline \multicolumn{3}{|c|}{ Sobre o autor } \\
\hline $\begin{array}{l}\text { 1.1. Trata-se de pessoa } \\
\text { reconhecida na área de } \\
\text { dicionarística ou de } \\
\text { terminologia? }\end{array}$ & \multicolumn{2}{|c|}{$\begin{array}{l}\text { A obra é atribuída à Universidade de Alcalá de Henares. Departamento de } \\
\text { Filologia. }\end{array}$} \\
\hline $\begin{array}{l}\text { 1.2. Fez parte de grupo de } \\
\text { pesquisa da área de } \\
\text { dicionarística ou de } \\
\text { terminologia? }\end{array}$ & \multicolumn{2}{|c|}{$\begin{array}{l}\text { A obra original conta com a colaboração de uma equipe de lexicógrafos e } \\
\text { lexicólogos. }\end{array}$} \\
\hline $\begin{array}{l}\text { 1.3. Qual a formação } \\
\text { acadêmica do autor } \\
\text { principal e dos participantes } \\
\text { do } \\
\text { grupo de pesquisa? }\end{array}$ & \multicolumn{2}{|l|}{ Não se aplica. } \\
\hline $\begin{array}{l}\text { 1.4. Qual a profissão } \\
\text { exercida na época da } \\
\text { publicação da obra em } \\
\text { análise? }\end{array}$ & \multicolumn{2}{|l|}{ Não se aplica. } \\
\hline \multicolumn{3}{|c|}{ 2. Sobre a apresentação da obra } \\
\hline \multirow[t]{4}{*}{$\begin{array}{l}\text { 2.1. Há introdução na qual } \\
\text { apareçam claramente? }\end{array}$} & a) os objetivos da obra? & $\begin{array}{l}\text { O objetivo da obra é fornecer aos estudantes } \\
\text { de espanhol de nível intermediário ajuda } \\
\text { necessária para ler, falar, escrever a língua } \\
\text { espanhola com eficácia. }\end{array}$ \\
\hline & $\begin{array}{l}\text { b) o público para o qual o } \\
\text { conteúdo se dirige? }\end{array}$ & $\begin{array}{l}\text { A obra é destinada a estudantes brasileiros de } \\
\text { nível intermediário, principalmente os que } \\
\text { "se aproximam do espanhol ou trabalham } \\
\text { com ele como segunda língua ou língua } \\
\text { estrangeira". }\end{array}$ \\
\hline & $\begin{array}{l}\text { c) as informações sobre } \\
\text { como consultar o dicionário } \\
\text { ou vocabulário? }\end{array}$ & $\begin{array}{l}\text { Sim, há apresentação da obra contendo } \\
\text { informações sobre como consultar o } \\
\text { dicionário, características gerais, seleção e } \\
\text { ordenamento das entradas, transcrição } \\
\text { fonética, guia de uso, abreviaturas e } \\
\text { símbolos. }\end{array}$ \\
\hline & $\begin{array}{l}\text { d) referências à bibliografia } \\
\text { de onde foi extraído o } \\
\text { corpus? }\end{array}$ & $\begin{array}{l}\text { Extraído do VOX-Biblograf, e os mais } \\
\text { difundidos manuais de espanhol para } \\
\text { estrangeiros. }\end{array}$ \\
\hline $\begin{array}{l}\text { 2.2. Há bibliografia de } \\
\text { consulta justificada pelo } \\
\text { autor? }\end{array}$ & \multicolumn{2}{|l|}{ Não. } \\
\hline \multicolumn{3}{|c|}{ 3. Sobre a apresentação material da obra } \\
\hline $\begin{array}{l}\text { 3.1. Há prefácio redigido } \\
\text { por }\end{array}$ & \multicolumn{2}{|c|}{ Sim, por Francisco Moreno Fernández, na apresentação da edição espanhola. } \\
\hline
\end{tabular}




\begin{tabular}{|c|c|c|}
\hline \multicolumn{3}{|l|}{$\begin{array}{l}\text { reconhecida na área de } \\
\text { dicionarística? }\end{array}$} \\
\hline $\begin{array}{l}\text { 3.2. A família tipográfica } \\
\text { empregada é adequada à } \\
\text { faixa etária do usuário? }\end{array}$ & \multicolumn{2}{|c|}{$\begin{array}{l}\text { A fonte utilizada na obra é adequada à leitura, com espaçamento entre as } \\
\text { linhas. A fonte é preta e as entradas são em negrito. }\end{array}$} \\
\hline $\begin{array}{l}\text { 3.3. As ilustrações, se } \\
\text { houver, estão adequadas à } \\
\text { microestrutura } \\
\text { informacional? }\end{array}$ & \multicolumn{2}{|c|}{$\begin{array}{l}\text { A obra traz ilustrações complementares à descrição dos significados em } \\
\text { verbetes que descrevem, por exemplo, a fauna e a flora. Há quadros } \\
\text { temáticos no corpo do dicionário como: acidentes geográficos do litoral } \\
\text { (quadro sobre a costa, p. 356), itens de composição do banheiro (quadro } \\
\text { sobre cuarto de baño, p. 370), estrutura óssea do corpo humano (quadro } \\
\text { sobre o hueso, p.668). As ilustrações são em preto e branco. }\end{array}$} \\
\hline $\begin{array}{l}\text { 3.4. A utilização de negrito, } \\
\text { de itálico e de outros } \\
\text { recursos gráficos está de } \\
\text { acordo com o equilíbrio } \\
\text { visual da obra }\end{array}$ & \multicolumn{2}{|c|}{$\begin{array}{l}\text { Sim, os destaques estão em equilíbrio visual, não há excesso de cores. A } \\
\text { entrada e o correspondente em português são em negrito. As definições são } \\
\text { sem destaques. Os exemplos são em itálico. }\end{array}$} \\
\hline $\begin{array}{l}\text { 3.5. Os verbetes são } \\
\text { apresentados em ordem } \\
\text { alfabética? }\end{array}$ & \multicolumn{2}{|c|}{ Os verbetes estão apresentados em ordem alfabética. } \\
\hline $\begin{array}{l}\text { 3.6. A obra contempla uma } \\
\text { só língua? Mais de uma? }\end{array}$ & \multicolumn{2}{|c|}{ A obra é semibilíngue: espanhol e português. } \\
\hline $\begin{array}{l}\text { 3.7. O formato do } \\
\text { dicionário ou vocabulário } \\
\text { permite manuseio prático e } \\
\text { fácil? }\end{array}$ & \multicolumn{2}{|c|}{$\begin{array}{l}\text { A obra é de manuseio prático e fácil, possui } 21,5 \mathrm{~cm} \text { de altura, } 14 \mathrm{~cm} \text { de } \\
\text { largura e } 4,5 \mathrm{~cm} \text { de espessura. Contém } 1510 \text { páginas. }\end{array}$} \\
\hline $\begin{array}{l}\text { 3.8. A obra está editada em } \\
\text { suporte informatizado? }\end{array}$ & \multicolumn{2}{|l|}{ A obra é impressa. } \\
\hline $\begin{array}{l}\text { 3.9. A qualidade do } \\
\text { acabamento garante a sua } \\
\text { durabilidade? }\end{array}$ & \multicolumn{2}{|c|}{ A qualidade do material segue os padrões para livros pedagógicos. } \\
\hline $\begin{array}{l}3.10 . \text { O sistema de } \\
\text { abreviações e de símbolos } \\
\text { aparece corretamente no } \\
\text { corpo do texto? }\end{array}$ & \multicolumn{2}{|c|}{$\begin{array}{l}\text { Sim, há sistema de abreviaturas e símbolos, que são apresentados na parte } \\
\text { inicial do dicionário. }\end{array}$} \\
\hline $\begin{array}{l}\text { 3.11. A obra possui ampla } \\
\text { divulgação? }\end{array}$ & \multicolumn{2}{|c|}{$\begin{array}{l}\text { É uma obra divulgada em sites de venda pela internet, nas livrarias e } \\
\text { indicado em escolas e cursos de línguas. }\end{array}$} \\
\hline \multicolumn{3}{|l|}{ 4. Sobre o conteúdo } \\
\hline $\begin{array}{l}\text { 4.1. As entradas cobrem de } \\
\text { maneira exaustiva a língua } \\
\text { oral e escrita, inclusive } \\
\text { neologismos, palavras } \\
\text { derivadas, etc.? }\end{array}$ & \multicolumn{2}{|c|}{$\begin{array}{l}\text { A obra contém } 22.000 \text { entradas. Não tem por propósito ser exaustiva e sim } \\
\text { oferecer o léxico necessário ao estudante em nível intermediário de } \\
\text { aprendizagem. }\end{array}$} \\
\hline \multirow[t]{5}{*}{$\begin{array}{l}\text { 4.2. Os } \quad \text { verbetes } \\
\text { apresentam? }\end{array}$} & a) categoria gramatical? & $\begin{array}{l}\text { Sim, apresenta categoria gramatical, que se } \\
\text { apresenta em forma abreviada e em destaque } \\
\text { (negrito e itálico), por exemplo, conj. para } \\
\text { conjunção. }\end{array}$ \\
\hline & b) gênero? & $\begin{array}{l}\text { Sim, apresenta o gênero, de forma abreviada } \\
\text { e em destaque (negrito e itálico), por } \\
\text { exemplo, } f \text {. para feminino. }\end{array}$ \\
\hline & c) sinonímia? & $\begin{array}{l}\text { Sim. Nos verbetes que apresentam sinônimos } \\
\text { ou palavras relacionadas, há indicação } \\
\text { sinalizada por }=>\text {, localizado na parte final, } \\
\text { antes do correspondente em português. } \\
\text { Por exemplo, con.gruen.te [...] }=>\text { acorde, } \\
\text { coherente. }\end{array}$ \\
\hline & d) variante(s) da entrada? & Não. \\
\hline & e) variante(s) da definiçãa? & Não. \\
\hline
\end{tabular}




\begin{tabular}{|c|c|c|}
\hline & $\begin{array}{l}\text { f) existem critérios para } \\
\text { distinguir homonímia de } \\
\text { polissemia? Quais? }\end{array}$ & $\begin{array}{l}\text { Sim, na seção seleção e ordenamento das } \\
\text { entradas (página XI). }\end{array}$ \\
\hline & $\begin{array}{l}\text { g) há emprego de marcas de } \\
\text { uso? Como se classificam? }\end{array}$ & $\begin{array}{l}\text { Sim, (formal), (informal), (religião), (vulgar). } \\
\text { Entretanto, a marca religião deveria ser } \\
\text { registrada como subárea de especialidade. }\end{array}$ \\
\hline & $\begin{array}{l}\text { h) indicação de área ou } \\
\text { subárea de especialidade? }\end{array}$ & $\begin{array}{l}\text { Há alguns casos: matemática, música, } \\
\text { medicina. }\end{array}$ \\
\hline & $\begin{array}{l}\text { i) contexto? (exemplo ou } \\
\text { abonação?) }\end{array}$ & Sim, há exemplos de uso. \\
\hline & j) equivalente(s)? & Sim. \\
\hline & k) formação da palavra? & Não. \\
\hline & 1) indicação de pronúncia? & $\begin{array}{l}\text { Sim, a obra contém uma parte destinada à } \\
\text { fonética com indicativo da pronúncia e } \\
\text { explicações sobre os sons da língua espanhola } \\
\text { e ilustrações sobre a articulação fonética. }\end{array}$ \\
\hline & m) origem? & Não. \\
\hline & o) divisão silábica? & Sim. \\
\hline & $\begin{array}{l}\text { q) remissivas úteis entre } \\
\text { conceitos? }\end{array}$ & $\begin{array}{l}\text { Sim, apresenta sistema de remissivas. Por } \\
\text { exemplo: } \quad \text { con.fu.cio.nis.mo } \\
\mid \text { konfuOionísmo } \mid \Rightarrow \text { confucianismo } \triangle \text { La } \\
\text { Real Academia Española prefere la forma } \\
\text { confucianismo. } \\
\text { A definição está localizada no item lexical } \\
\text { indicado pela remissão. }\end{array}$ \\
\hline & r) fontes? & Não apresenta. \\
\hline & s) notas? & $\begin{array}{l}\text { Apresenta algumas notas quando os itens não } \\
\text { apresentam equivalentes, como, por exemplo, } \\
\text { pratos da culinária espanhola. }\end{array}$ \\
\hline 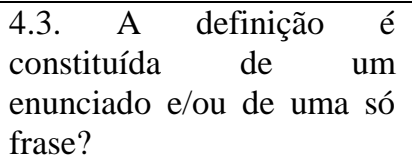 & Há definição e é construída & or enunciado. \\
\hline $\begin{array}{l}\text { 4.4. A definição leva em } \\
\text { conta o nível de discurso do } \\
\text { usuário? }\end{array}$ & Sim. & \\
\hline Observação & $\begin{array}{l}\text { Esse dicionário é adaptado } \\
\text { enseñanza de la lengua espc } \\
\text { controlado. contém } 2000 \text { pal }\end{array}$ & $\begin{array}{l}\text { o dicionário monolíngue Diccionario para la } \\
\text { ñola. As definições são compostas por léxico } \\
\text { vras definidoras. }\end{array}$ \\
\hline
\end{tabular}


Assim como o dicionário Larousse, o dicionário SEÑAS também segue os padrões internacionais de catalogação para publicação; informa o título, o autor, a coordenação de tradução, o nome dos tradutores, a editora, a data e local da publicação. É uma obra reduzida do dicionário de espanhol monolíngue para estrangeiros, Diccionario Vox para la Enseñanza de la Lengua Española, com o núcleo do verbete na língua espanhola e a apresentação de um correspondente em língua portuguesa para cada acepção. A autoria é atribuída a Universidade de Alcalá de Henares, Departamento de Filologia, que conta com uma equipe de lexicógrafos.

Nas páginas iniciais, localizam-se o índice geral, a apresentação da edição brasileira, a apresentação da edição espanhola, o guia para consultar o dicionário, lista de abreviaturas, a lista de pronúncia, instruções de como interpretar a informação sobre a pronúncia, a correspondência entre símbolos fonéticos e grafias, as informações sobre a articulação dos sons com ilustrações. As apresentações são na L1 do usuário, para facilitar a compreensão das instruções de uso e das diretrizes que orientaram a elaboração do dicionário. Isso ocorre porque os dicionários semibilíngues consideram desde a concepção do projeto lexicográfico que a língua utilizada na obra não é a L1 do usuário.

A apresentação da edição brasileira informa a quantidade de entradas, 22.000 e mais de 45.000 significados, assim, o dicionário é classificado como obra de pequeno porte, mesmo contendo 1510 páginas, por causa conteúdo detalhado. As definições são elaboradas utilizando um vocabulário controlado com 2.000 palavras. Portanto, percebe-se que o número de entradas das obras semibilíngues tende a ser menor que nas obras bilíngues em vista da quantidade de informações contidas nos semibilíngues.

Quanto à forma, o dicionário SEÑAS é classificado como de médio porte, ao consideramos também as dimensões: $21,5 \mathrm{~cm}$ de altura, $14 \mathrm{~cm}$ de largura, $4,5 \mathrm{~cm}$ de espessura e o número de páginas. A apresentação da edição espanhola é detalhada, porque contém o objetivo da obra, “fornecer aos estudantes de espanhol de nível intermediário a ajuda necessária para ler, falar e escrever nossa língua com mais eficácia"; informa a fonte do corpus: os dicionários e estudos de frequência, os léxicos básicos do espanhol recolhidos até aquele momento, os léxicos de ensino, os mais difundidos manuais de espanhol para estrangeiros e o Corpus VOX-Biblograf; apresenta informações sobre linguagens de especialidade, registro de uso e sentido, instruções sobre a regência e os tipos de complementos; registra explicações sobre os símbolos utilizados na obra; e descreve a estrutura das definições e dos exemplos. 
A macroestrutura do dicionário semibilíngue, conforme ilustrado pelo dicionário SEÑAS, apresenta elementos estruturais organizados de modo pedagógico para auxiliar os estudantes em fase de aprendizagem. O guia de uso, por exemplo, orienta o consulente a ler o texto lexicográfico para que ele possa identificar e fazer melhor uso das informações contidas no dicionário. No guia do dicionário SEÑAS, há exemplos de verbetes com sinalização e as explicações das partes que o compõem, como demonstrado a seguir:

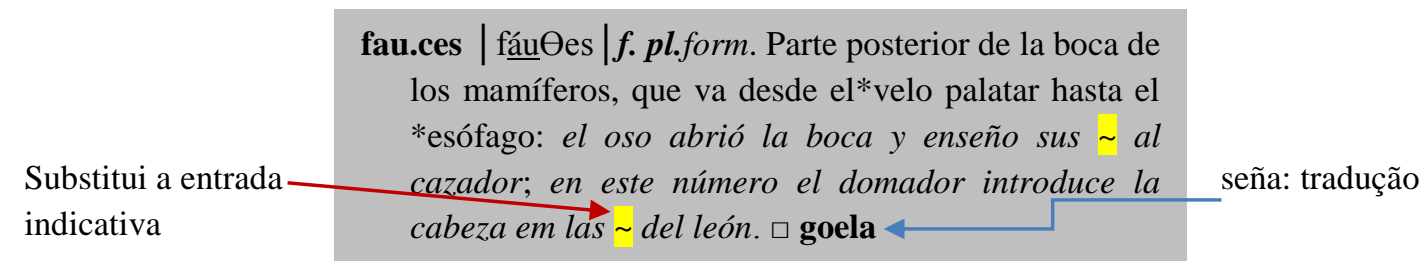

Os anexos são selecionados a partir de um conjunto de informações necessárias ao processo de aprendizagem da língua-alvo, como a gramática sucinta. Entretanto, o dicionário SEÑAS não inclui nos anexos lista de números cardinais e ordinais, nem lista dos países com os respectivos gentílicos. Essas informações são importantes para o aprendiz em fase inicial, uma vez que números e gentílicos fazem parte do léxico cotidiano.

\subsubsection{A microestrutura dos dicionários}

Na composição de um dicionário, a microestrutura é a parte mais consultada, porque contém o conjunto de informações específicas de cada palavra. Para Haensch (1997, p. 41) a microestrutura de um dicionário es la ordenación de todos los elementos que componen um artículo $^{20}$ lexicográfico, também denominado verbete. Faulstich (2011, p. 183) esclarece que "o verbete constitui a microestrutura do dicionário, além de ser a parte, efetivamente, lexicográfica da obra". Em função do público-alvo e do propósito, a microestrutura pode variar. De modo geral, os elementos de composição da microestrutura são: entrada ou lema, pronúncia, ortografia, informações morfológicas, categoria gramatical, gênero gramatical, aspectos sintáticos, definições, marcas de uso, exemplos de uso, sinônimos, antônimos, informações etimológicas e equivalentes (esse último nos dicionários com mais de uma língua).

\footnotetext{
${ }^{20} \mathrm{E}$ a ordenação de todos os elementos que compõem um artigo (lexicográfico).
} 
Entrada ou lema es la parte enunciativa de um artículo, cuyo objectivo es la descripción y explicación del lema; en el caso de combinaciones de otras palabras com el lema, también de otras unidades léxicas ${ }^{21}$ (HEANSCH, 1982, p. 462). A apresentação da entrada ou lema, normalmente, utiliza algum tipo de recurso de destaque como negrito, letras maiúsculas ou colorido.

As definições correspondem à verbalização do significado ou dos significados que a entrada ou lema pode apresentar no discurso. As definições podem ser de tipos variados, como sinonímico, analítico e ostensivo. Carvalho (2011, p. 92-95), com base em Weinreich (1984), apresenta as distinções das definições do seguinte modo:

\begin{abstract}
Na sinonímia, faz-se uso de palavras ou expressões pertencentes à mesma classe da palavra-entrada, consideradas sinônimas "perfeitas".

No analítico, a explicitação do significado faz-se por meio de análise semântica componencial - também conhecida como definição aristotélica ou intencional, em que a decomposição do significado é revelada em duas partes: um hiperônimo, que estabelece a categoria genérica (genus), e uma descrição específica (differentia), com as propriedades inerentes àquilo que está sendo descrito, de modo a diferenciá-lo dos outros elementos pertencentes à categoria hiperonímica geral.

No ostensivo, consiste na especificação de elementos que pertencem ao conjunto denominado pela palavra-entrada (denotata), em lugar da explicitação do significado.
\end{abstract}

Quanto aos tipos de definição, há, ainda, a oracional, que é elaborada por meio de enunciados completos, com "estruturas sintáticas variadas para explicitar os significados, segundo a classe da palavra e suas características inerentes, a inclusão da palavra-entrada no enunciado definitório, além das marcas linguísticas, como vocês, nós, a gente" (CARVALHO, 2011, P. 103).

As marcas de uso indicam as especificidades que influenciam a variação dos significados como aspectos geográficos, estilísticos, cronológicos ou de especialidade. Segundo Haensch (1997, p. 41), as marcas delimitam o uso do seguinte modo:

marcas geográficas, que señalan en qué países o áreas geográficas se usa una unidad léxica o una acepción de ella;

marcas estilísticas, que señalan las unidades léxicas que pertenecen al un nível, por ej. formal, burocrático, irónico etc.

marcas cronológicas, que especifican si la unidad léxica descrita es arcaica (obsoleta), ou un neologismo (especialmente cuando aún no se sabe

\footnotetext{
${ }^{21}$ É a parte enunciativa do artigo (lexicográfico), cujo objetivo é a descrição e a explicação do lema; no caso de combinações de outras palavras com o lema, também de outras unidades léxicas.
} 
todavía si éste será integrado en el léxico de la lengua o sustituido por otra unidade léxica.

marcas de especialidade, que señalan la unidad léxica tratada o una acepción de ella pertenece a una determinada especialidad o campo, por ej. medicina, agricultura, fútebol. ${ }^{22}$

Exemplos de uso registram a existência da unidade léxica em contexto reais da comunidade em que a língua utilizada. Ilustram, assim, o aspecto morfossintático e o semântico da unidade léxica em conjunto com outras unidades.

Equivalentes, termo utilizado nos temas sobre lexicografia bilíngue, referem-se às unidades lexicais que apresentam significado próximo ao correspondente da entrada ou lema, em outra língua. Conforme Carvalho (2006, p. 111) registra, "as equivalências constituem o objetivo imediato do dicionário bilíngue, pois é à procura delas que o usuário vai, ao consultá-lo".

A microestrutura, organizada com fins pedagógicos, apresenta aspectos gráficos variados, em que recursos, como destaques em negrito, em itálico, em letras maiúsculas, e em cores distintas, são utilizados com funções específicas. A entrada é "a unidade léxica, também chamada 'cabeça do verbete' ou lema, que comanda todas as informações que compõem o verbete" (FAULSTICH, 2011, p. 184). Normalmente, aparece em negrito ou em letras maiúsculas. As informações gramaticais e morfológicas são grafadas em itálico ou em cores, como azul ou vermelho. Para Guerra (2003, p.105), a sistematização desses recursos facilita a codificação de determinadas informações, e acrescenta:

También constituyen un recurso de gran provecho signos ortográficos auxiliares como la pleca (|) y la doble pleca $(\|)$ para separar acepciones, la virgulilla $(\sim)$ para sustituir palabras que en el artículo se repiten con fecuencia (como el lema en los ejemplos), el asterisco (*), así como los paréntesis y los corchetes, muy utilizados para distinguir en los enunciados definitorios los contornos de la definición. ${ }^{23}$ (GUERRA, 2003, p. 106).

\footnotetext{
${ }^{22}$ Nomes geográficos que indicam em quais países ou áreas geográficas uma unidade lexical ou o significado do que é utilizado; marcas estilísticas, que indicam os itens lexicais pertencentes a um nível, por exemplo, formal, burocrático, irônico etc.; marcas cronológicos que especificam se a unidade lexical descrita é arcaica (desatualizada), ou um neologismo (especialmente quando ainda não se sabe se o item será integrado ao léxico da língua ou substituído por outra Unidade lexical e marcas especiais que indicam a unidade lexical ou o significado que pertence a uma área de especialidade ou a um campo específico, por exemplo, medicina, agricultura, futebol.

${ }^{23}$ Também constituem um recurso de grande utilidade as marcações gráficas, como barra simples ( | ) ou barra dupla (\|) para separar os significados, o til $(\sim)$, para substituir as palavras que se repetem no verbete com frequência (como as entradas nos exemplos), o asterisco $(*)$ assim como os parênteses ou colchetes são muito utilizados para distinguir as delimitações das definições.
} 
Para que a aprendizagem seja satisfatória, símbolos e códigos devem estar bem sistematizados e com explicações detalhadas na parte introdutória da obra, em seção do tipo guia de uso, caso contrário perde-se a finalidade pedagógica, pois o usuário de dicionários inexperiente terá de deduzir o significado. Pela natureza do objeto, nos dicionários pedagógicos, deve-se evitar o excesso de símbolos no corpo do verbete para que a leitura do texto lexicográfico tenha mais fluidez. A seguir, ilustramos a estrutura de verbete de dicionário bilíngue Larousse e do semibilíngue SEÑAS.

\section{Inglês-Português (bilíngue) \\ dinner $\left[{ }^{\prime} \mathrm{d} I n \partial^{\mathrm{r}}\right]$ n. -1. [meal - in evening] jantar $m$ [- at midday] almoço $m$-2. [formal event] jantar $m$.}

\section{Espanhol-Português (semibilíngue)}

ce.nar $\mid$ Өenár| 1 intr. Tomar la última comida que se hace em el día, por la noche: Juan Carlos nos invitó a $\sim$ en un restaurante vegetariano. $\Rightarrow$ almorzar, comer, desayunar, merendar. $\square$ jantar $\mathbf{- 2}$ tr. [algo] Tomar um alimento determinado en la última comida que se hace em el día: esta noche cenaremos filetes de ternera. $\square$ jantar

Os exemplos apresentados mostram que a estrutura do dicionário bilíngue é sucinta, porque apresenta a entrada, a transcrição fonética, a categoria gramatical, a delimitação do significado e o equivalente em português. Não há definição, nem exemplo de uso da unidade lexical. Já a microestrutura do semibilíngue é mais detalhada, apresenta a entrada, a transcrição fonética, a tipologia verbal, a definição oracional, o exemplo de uso, a remissiva para palavras do mesmo campo lexical e o correspondente em português.

A inclusão da definição no dicionário SEÑAS possibilita que o usuário identifique os aspectos conceituais que atuam na construção do significado. Do mesmo modo, a inclusão de exemplos que ilustram o uso da unidade lexical contribui para que o usuário perceba os aspectos morfossintáticos e semânticos em enunciado da língua-alvo, pois somente a inclusão de equivalentes na L1 do usuário limita o processo de aprendizagem.

\subsubsection{Problemas dos dicionários bilíngues quanto ao público-alvo.}

A relação entre o dicionário e o público-alvo orienta a composição da microestrutura, de acordo com a faixa etária dos usuários e a finalidade do dicionário. 
Para discutir essa questão, apresentamos aspectos da microestrutura do Dicionário Larousse Inglês/Português- Português/Inglês: essencial; dicionário essencial para o aprendizado da língua inglesa e, para isso, os problemas dessa estrutura lexicográfica para aprendizes de PSL. Selecionamos dois verbetes para exemplificar os problemas. O ponto de partida para a seleção dos verbetes recaiu sobre verbos que são essenciais para a vida do ser humano: comer e beber. Partimos do pressuposto de que o aprendiz teve contato com essas palavras, em contextos diversificados, e pretende ampliar seus conhecimentos sobre esses verbos com o auxílio do dicionário. Então, confrontamos as informações extraídas de dicionário com os significados variados que comer e beber apresentaram, conforme alguns enunciados selecionados de revistas, de textos disponíveis na internet, e de filmes nacionais.

Os enunciados selecionados para a análise são os que seguem:

1. Lugar para comer sem pressa, o Guamaré mantém um atendimento simpático, garantindo por Nádia e Risima - respectivamente, mulher e irmão do dono. (Revista Veja comer \&beber)

2. Ator comeu carne recheada com patê de fígado. (G1.globo.com)

3. A traça comeu a roupa que estava no armário. (Gazeta online. Globo)

4. Porque o filho inventa grafias, 'come' letras - escrevendo boneca apenas com 'bnc', por exemplo. (Revista Crescer)

5. Seu Jorge, já comeu uma loira? (Filme: E aí, comeu?)

6. Inflação acelerada come salário do trabalhador neste ano. (R7 - Notícias)

7. Ganha o jogo quem comer todas as peças do adversário. (150 ideias para trabalho com criança, p. 33)

8. Com o tempo seco, beba 2 litros de água por dia. (G1. Globo)

9. Também dê a eles algo para comer e beber. (Revista Viagem)

10. Adolescentes começam a beber cada vez mais cedo. (Revista Veja)

11. Dez hábitos do motorista que fazem o carro 'beber' mais. (G1. Globo)

Os verbetes comer e beber do dicionário Larousse (2009) apresentará as seguintes informações ao aprendiz de PSL, caso ele venha utilizar esse dicionário: 


\section{Verbete 1}

comer $\left[\mathrm{ko}^{\prime} \mathrm{me}(\mathrm{x})\right](p l$-es $) \diamond \boldsymbol{v t}$-1. [alimentar-se de] to eat. -2. fig [suprimir] to swallow. 3.fig [corroer] to corrode. -4.fig [consumir] to devour. -5. [em damas, xadrez] to take. -6. vulg fig [sexualmente] to fuck. $\diamond v i$ [alimentar-se] to eat; dar de $\sim$ a alguém to feed sb.

\section{Verbete 2}

beber [be 'be(x)] $\boldsymbol{v t} \mathbf{- 1}$. [tomar líquido] to drink. -2. [absorver] to soak up. vi -1. [tomar bebida alcoólica] to have a drink. -2. [embriagar-se] to get drunk.

A estrutura do verbete comer traz uma informação ( $p l-\mathbf{e s ) ~ c o m u m ~ p a r a ~ i n d i c a r ~ p l u r a l ~}$ de alguns substantivos, válido para o uso de comer como substantivo, talvez em: Os comeres de alguém. Porém, em um verbete que descreve um verbo essa informação é impertinente porque não há indicação de que a palavra pode desempenhar o papel de substantivo. O uso do símbolo que indica mudança quanto ao tipo de verbo não é explicado no dicionário, portanto cabe ao aprendiz decodificar o símbolo. O verbete apresenta delimitação do significado, mas traz exemplo, somente no final, logo o aprendiz não poderá perceber como de fato a palavra se comporta na língua portuguesa conforme as outras acepções. Quanto ao verbete beber, a exclusão de exemplos é total.

Em primeira análise, a estrutura dos verbetes contribui para a compreensão do item lexical, pois oferece possibilidades de palavras correspondentes na L1 do aprendiz. Contudo, delega ao aprendiz depreender qual das opções é mais apropriada ao enunciado que deseja produzir.

Para aprofundar nossa análise sobre a microestrutura desse dicionário, elaboramos uma ficha para avaliar as informações contidas nos verbetes de comer e beber, e, assim, verificar as relações internas do dicionário que auxiliem na ampliação do conhecimento dos possíveis significados desses verbos, nos enunciados correlacionados. 
Ficha lexicográfica de verbetes de dicionários bilíngues 1. (usados por estudantes de PBSL)

\section{Ficha 1: COMER}

\section{Dado:}

1. Lugar para comer sem pressa, o Guamaré mantem um atendimento simpático, garantindo por Nádia e Risima - respectivamente, mulher e irmão do dono (Revista Veja comer \&beber) $\rightarrow$ alimentar-se, tomar alimento.

2. Ator comeu carne recheada com patê de fígado. (G1.globo.com) $\rightarrow$ alimentar-se, mastigar e engolir, ingerir alimento sólido.

3. A traça comeu a roupa que estava no armário. (gazeta online. Globo) $\rightarrow$ danificar, destruir.

4. Porque o filho inventa grafias, 'come' letras - escrevendo boneca apenas com 'bnc', por exemplo. (Revista Crescer) $\rightarrow$ eliminar, omitir.

5. Seu Jorge, já comeu uma loira? (Filme: E ai, comeu?) $\rightarrow$ copular, possuir sexualmente.

6. Inflação acelerada come salário do trabalhador neste ano. (R7 - Notícias) $\rightarrow$ consumir, dilapidar.

7. Ganha o jogo quem comer todas as peças do adversário. (150 ideias para trabalho com criança, p. 33) $\rightarrow$ excluir eliminar.

Referência: Dicionário Larousse Inglês/Português . Português/Inglês: essencial Editora: Larousse do Brasil/ coordenação editorial José A Gálvez. 2a edição. São Paulo: Larousse do Brasil, 2009.

Público-alvo: A obra é destinada a estudantes (em aprendizagem formal ou informal) da língua inglesa, do nível básico ao nível intermediário, profissionais em geral, turistas e leitores que já estão no mercado de trabalho.

\begin{tabular}{|c|c|c|}
\hline Entrada & Comer & \multirow[b]{5}{*}{ 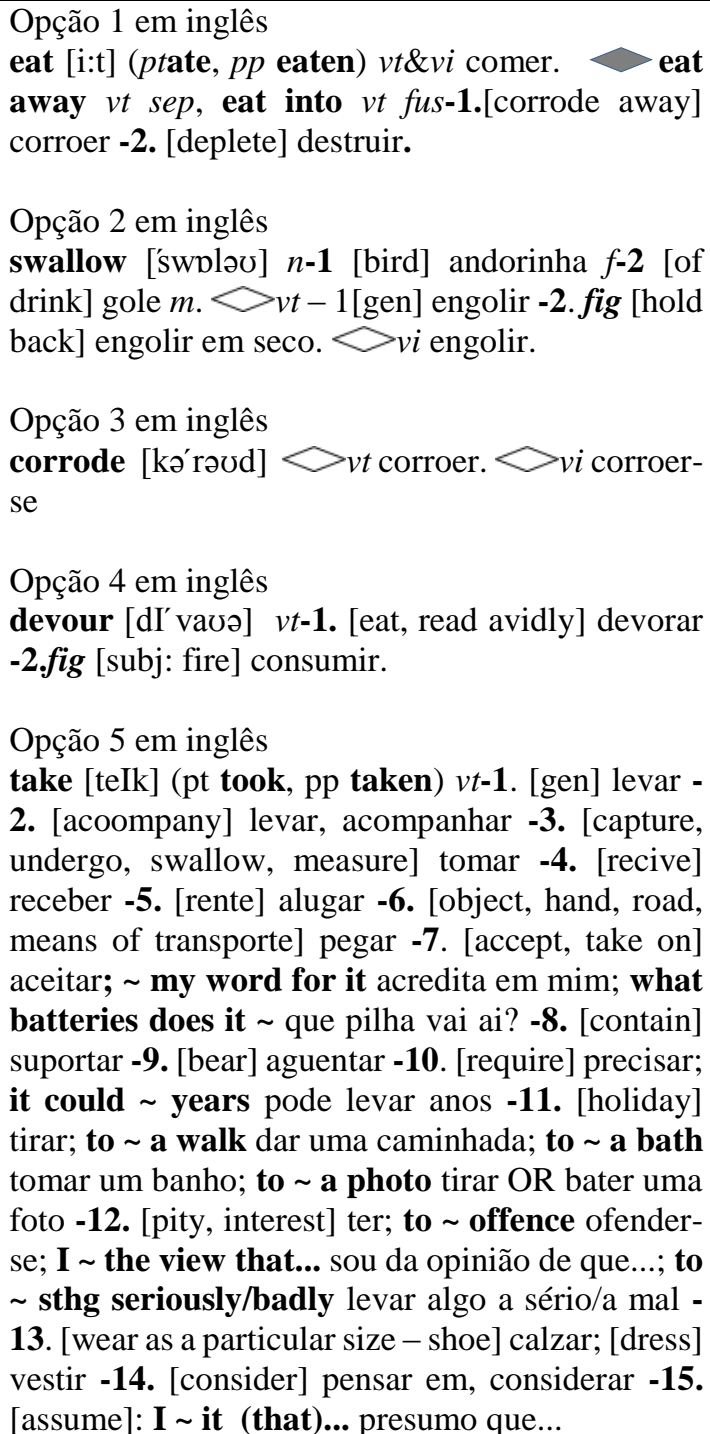 } \\
\hline $\begin{array}{l}\text { Transcriçãa } \\
\text { fonética }\end{array}$ & [ko'me(x)] & \\
\hline $\begin{array}{l}\text { Categoria } \\
\text { gramatical }\end{array}$ & $V t$ & \\
\hline Definição & 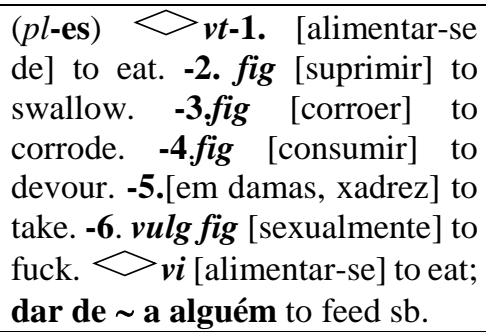 & \\
\hline opções em inglês & $\begin{array}{l}\text { to eat } \\
\text { to swallow } \\
\text { to corrode } \\
\text { to devour } \\
\text { to take } \\
\text { to fuck } \\
\text { to feed }\end{array}$ & \\
\hline
\end{tabular}




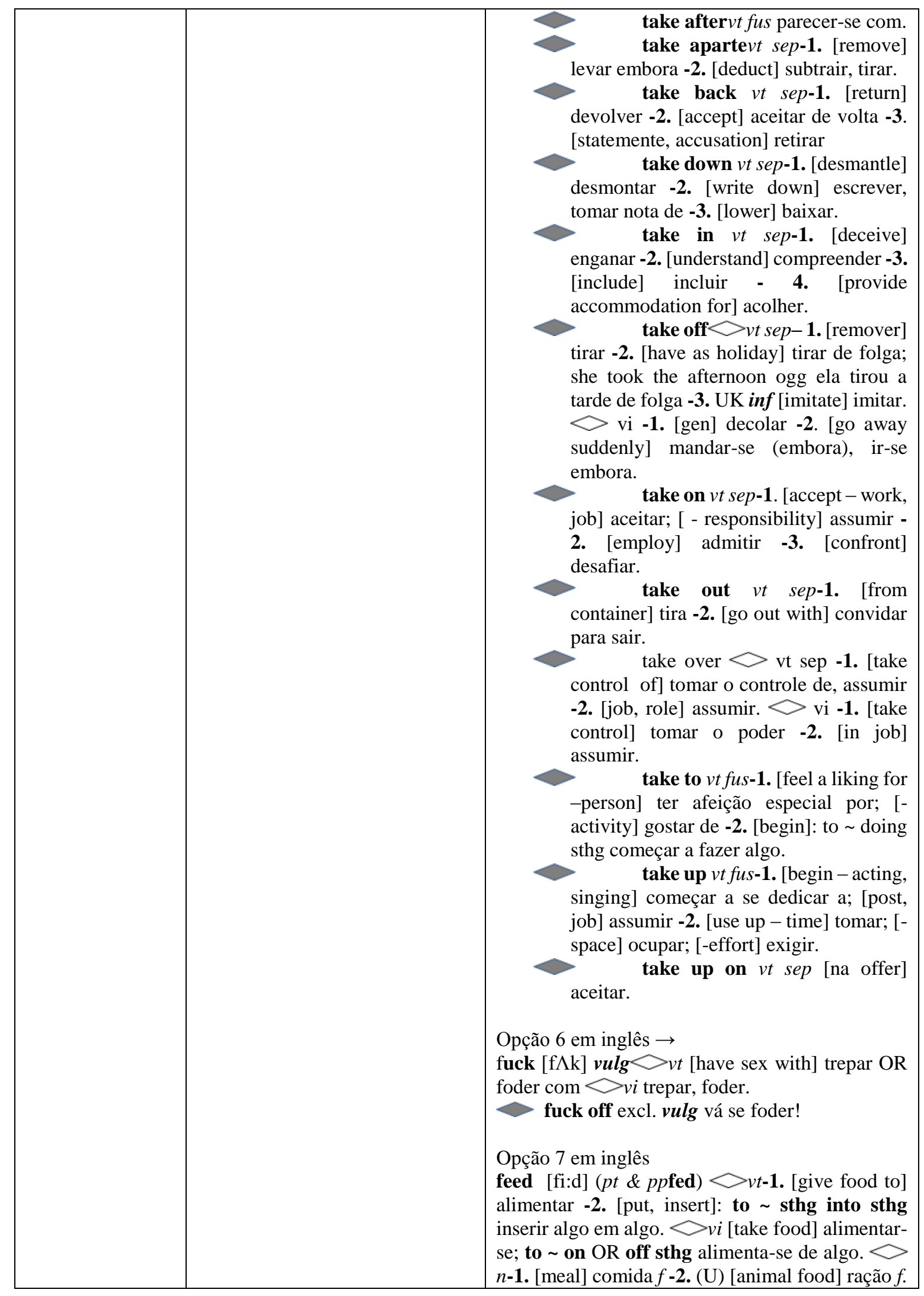


Observação: significado das abreviaturas encontradas na introdução

sep = separável, separable

fig = figurado, figurative

$f=$ substantivo feminino, feminine noun

$m=$ substantivo masculino, masculine noun

$n=$ substantivo, noun $\rightarrow$ regitrado como $s=$ substantivo, noun na versão português-inglês

vulg = vulgar, vulgar

$v t=$ verbo transitivo, transitive verb

$v i=$ verbo intransitivo, intransitive verb

fus $=$ inseparável, inseparable

inf $=$ familiar, informal $\rightarrow$ regitrado com fam $=$ familiar, informal na versão português-inglês

sthg $=$ algo, alguma coisa, something 
Ficha lexicográfica de verbetes de dicionários bilíngues 2. (usados por estudantes de PBSL)

\section{Ficha 2: BEBER}

\section{Dado:}

1. Com o tempo seco, beba 2 litros de água por dia. (G1. Globo) $\rightarrow$ ingerir (líquido)

2. Também dê a eles algo para comer e beber. (Revista Viagem) $\rightarrow$ ingerir (líquido)

3. Adolescentes começam a beber cada vez mais cedo. (Revista Veja) $\rightarrow$ ingerir bebida alcoólica ou embriagar-se

4. 10 hábitos do motorista que fazem o carro 'beber' mais. (G1. Globo) $\rightarrow$ consumir (muito combustível)

Referência: Dicionário Larousse Inglês/Português. Português/Inglês: essencial Editora: Larousse do Brasil/ coordenação editorial José A Gálvez. $2^{a}$ edição. São Paulo: Larousse do Brasil, 2009.

Público-alvo: A obra é destinada a estudantes (em aprendizagem formal ou informal) da língua inglesa, do nível básico ao nível intermediário, profissionais em geral, turistas e leitores que já estão no mercado de trabalho.

\begin{tabular}{|c|c|}
\hline Entrada & Beber \\
\hline $\begin{array}{l}\text { Transcrição } \\
\text { fonética }\end{array}$ & [be 'be(x)] \\
\hline $\begin{array}{l}\text { Categoria } \\
\text { gramatical }\end{array}$ & $v t$ \\
\hline Gênero & \\
\hline Definição & 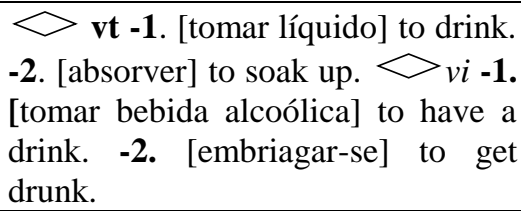 \\
\hline
\end{tabular}

Opção 1 em inglês
drink [drịk] ( $p t$ drank, $p p$ drunk $) \diamond \mathrm{n}$. 1. [non-alcoholic beverage] bebidaf 2.[alcoholic beverage] bebida $f$ alcoólica; to have a tomar um drink -3. (U) [alcohol] bebida $f$. $\diamond v t$ beber. $<$ vi beber.

\section{Opção 2 em inglês}

soak [səok] $\prec v t$-1. [leave immersed] pôr de molho -2. [wet thoroughly] ensopar; to be ed with sthg estar ensopado(da) de algo. $<v i$-1. [become thoroughly wet]: to leave sthg to $\sim$, to let sthg deixar algo de molho 2. [spread]: to $\sim$ into sthg espalhar-se por algo; to through (sthg) infiltrar-se em algo. soak up vt sep [liquid] absorver.

\begin{tabular}{|l|l|}
\hline Nota & \\
\hline Data & \\
\hline opções em inglês & $\begin{array}{l}\text { To drink } \\
\text { To soak up } \\
\text { To have a drink } \\
\text { To get drunk }\end{array}$ \\
\hline
\end{tabular}

\section{Opção 3 em inglês}

have [hæv] ( $p t \& p p$ had) $>a u x v b$-1. [to form perfect tenses]: I finished acabei; you been there? - no, I n't você já esteve lá? - não; they hadn't seen it não o tinham visto; we had already left nós já tínhamos saído -2. [must]: to $\sim$ (got) to do sthg ter de fazer algo; do you to pay? é preciso pagar? $\diamond v t$-1.[possess] to $\sim$ you $\sim \mathbf{O R} \sim$ you got a double room? Você tem um quarto de casal?; she's got brown hair ela tem o cabelo castanho -2. [exeperince] ter; to $\sim$ a cold estar resfriado; to $\sim$ a great time divertir-se a valer -3. [replacing otheer verb] ter; to $\sim$ breakfast tomar café da manhã; to $\sim$ a dinner jantar; to $\sim$ lunch almocar; to $\sim$ a bath tomar banho; to a drink tomar qualquer coisa, tomar um drinque; to $\sim$ a shower tomar banho; to $\sim$ a swin nadar -4. [feel] ter; I no doubt about it não tenho dúvida alguma $\mathrm{OR}$ nenhuma sobre isso $\mathbf{- 5}$. [cause to be]: to $\sim$ sthg done mandar fazer algo; to $\sim$ one's hair cut cortar o cabelo -6. [be treated in a certain way]: I've 


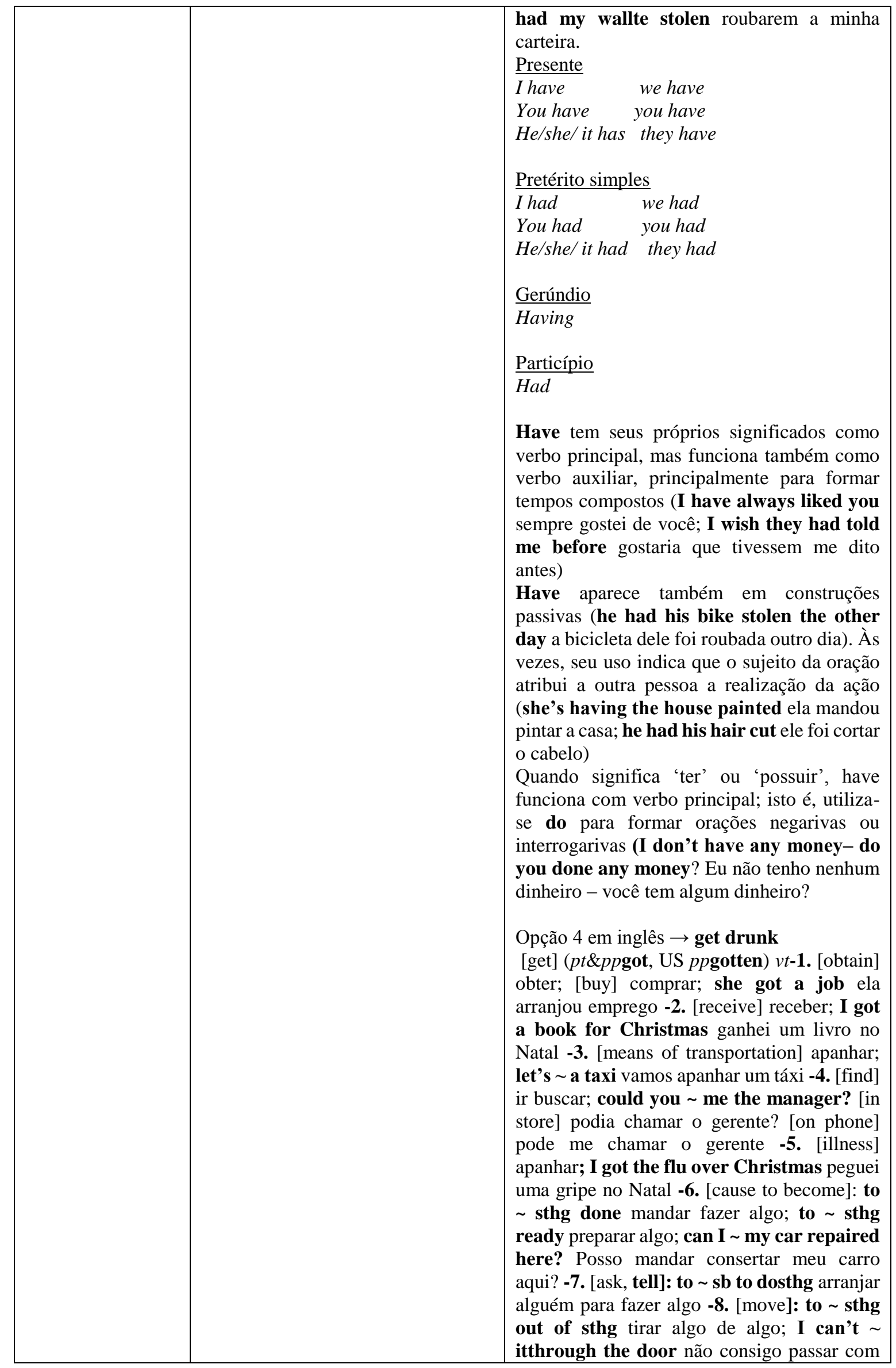




\begin{tabular}{|c|c|}
\hline & 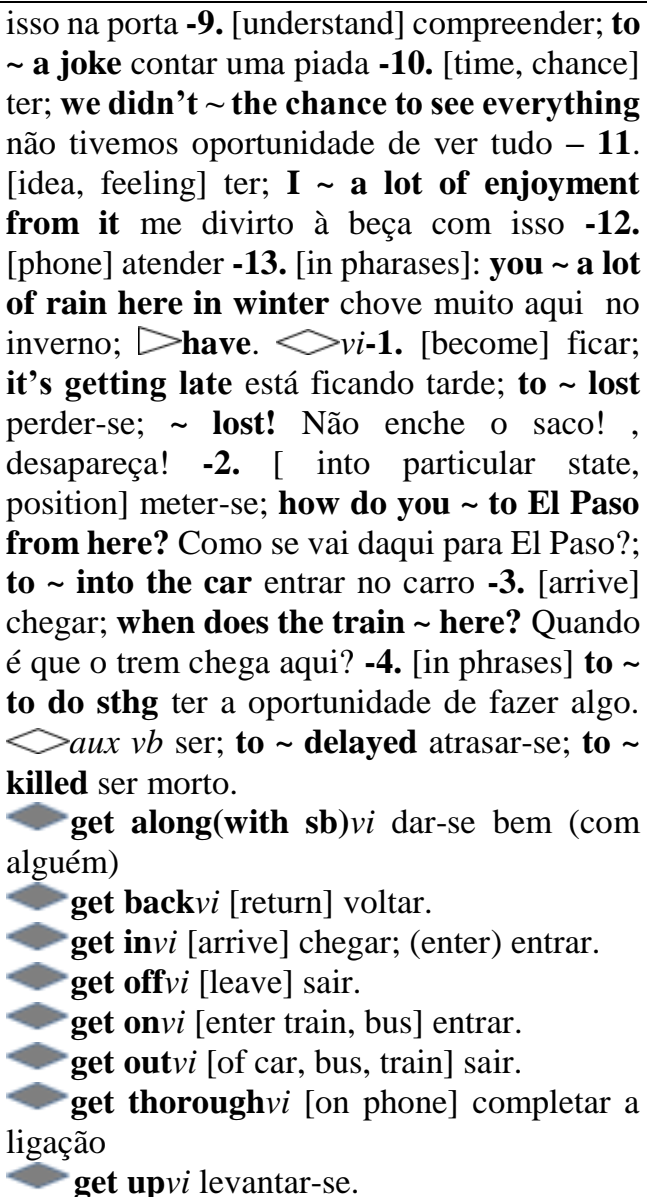 \\
\hline $\begin{array}{l}\text { Observação: } \\
s b=\text { alguém, somebory } \\
a u x v b=\text { verbo auxiliar, auxiliar veb } \\
v i=\text { verbo intransitivo, intransitive verb } \\
v t=\text { verbo transitivo, intransitive verb }\end{array}$ & \\
\hline
\end{tabular}

Das fichas 1 e 2, podemos afirmar que não há sistematicidade na inclusão de exemplos que ilustrem o uso das palavras, comer e beber e os respectivos significados, pois não há exemplos em todos os casos e nem explicação para o critério de quando haverá, na apresentação do dicionário.

Constatamos, por meio da análise da ficha 1, que há casos de registro de correspondentes que não são adequados ao contexto situacional da língua portuguesa falada no Brasil, como por exemplo: a opção 6 da análise de comer. Nessa opção, o significado do item lexical para compreensão do enunciado "Seu Jorge, já comeu uma loira?” é abordado pelo dicionário. Mas quanto ao processo de produção, caso o usuário quisesse produzir um enunciado com significado semelhante a esse no mesmo contexto situacional depois do consultar o verbete fuck, mesmo contendo a marcação de vulgar, as opções trepar ou foder 
não é adequado, seria considerado de uso agressivo e poderia causar problemas socioculturais ao aprendiz estrangeiro residente no Brasil.

A análise da ficha 2, demonstrou que, ao ler todos os verbetes sugeridos como possíveis equivalentes para o verbo beber, identificamos exemplos que não traziam o correspondente sugerido pelo dicionário, como na opção 4 da análise do verbo beber: -5 . [illness] apanhar; I got the flu over Christmas peguei uma gripe no Natal. O verbete sugere apanhar, mas no exemplo aparece o verbo pegar, que não é dado como equivalente em nenhuma das opções. Outro ponto negativo do dicionário é não conter mídia para a audição das palavras, e as obras bilíngues inglês-português que possuem esse recurso, normalmente, trazem áudio somente na versão inglesa, o que não colabora para a aprendizagem de PSL, por isso há a necessidade de dicionários para os aprendizes de PSL, evitando que eles utilizem obras que não são destinadas a eles.

Assim, a análise desses verbetes demonstra que, por serem públicos distintos, aprendizes do português como L2 e aprendizes brasileiros do inglês como LE, a microestrutura dessas obras apresenta certa deficiência às necessidades dos aprendizes do PSL. Isso colabora para a elaboração de dicionários específicos, segundo o público-alvo. Nesse sentido, enfatizamos que obras descritivas têm de ser construídas com bases científicas, visando à apresentação de uma realidade linguística e, nesse caso, destacamos o dicionário como obra fundamental para a aprendizagem com tratamento adequado para cada público-alvo.

Além disso, a análise dos dicionários aqui apresentados revelou que não considera efetivamente o contexto cultural, o contexto situacional e o contexto linguístico de modo sistemático para facilitar a aprendizagem de língua. Há casos em que há concentração somente de informações linguísticas como, ortografia, pronúncia e classe gramatical.

Portanto, para que o léxico do Português do Brasil esteja bem sistematizado, há necessidade de maior desenvolvimento da Lexicografia nacional, que pode ser aperfeiçoada por meio da aplicação das teorias linguísticas e dos recursos tecnológicos. Acerca dos recursos tecnológicos, passaremos a discorrer brevemente sobre essa ferramenta que tem contribuído para o avanço da lexicografia.

\subsubsection{A tecnologia aliada à construção de dicionários atuais}


O percurso feito sobre a história da Lexicografia indicou os avanços tecnológicos como aliados ao processo de elaboração de dicionários para aprendizagem de língua. A tecnologia não é uma opção, é uma necessidade no mundo moderno. Uma demonstração do avanço tecnológico é a internet, ferramenta que democratizou a divulgação do conhecimento. Hoje, encontram-se informações desde o melhor modo de organizar a mala de viagem até as informações sobre técnicas que aumentam a capacidade de observação de processos em seres vivos, em nível molecular. Em salas de aula, é possível conferir imediatamente informações que antes dependeriam do deslocamento à biblioteca ou a casa para consultar livros, dicionários ou enciclopédias.

A tecnologia vem transformando o processo de aprendizagem. A Lexicografia e outras áreas de estudo estão se beneficiando dessa mudança, assim os dicionários estão em processo de modernização. Desse modo, ferramentas de busca, áudio, vídeos, imagens e configurações são adaptadas para que as informações linguísticas e extralinguísticas estejam mais claras para o aprendiz, promovendo maior interação entre dicionário e usuário. Em vista disso, nossa proposta utilizará as ferramentas tecnológicas disponíveis para o processamento de dados, para elaboração do dicionário informatizado e para a divulgação do Dicverb/PL2 na internet, quando estiver concluído. 


\subsection{Síntese do capítulo}

Neste capítulo, apresentamos alguns aspectos do percurso da Lexicografia portuguesa para verificar as mudanças sofridas pelas obras lexicográficas em dicionários contemporâneos. Apresentamos algumas diretrizes que orientam a tipologia lexicográfica que se refletem na variedade de tipos de dicionários distintos encontrados em bibliotecas, livrarias e internet. Essas diretrizes serviram de base para identificarmos as principais características que o dicionário de aprendizagem de verbos do português como L2 apresentará e, assim, classificá-lo. Cotejamos algumas obras para confrontar a composição da macroestrutura e da microestrutura. Por fim, identificamos a tecnologia como aliada na inovação de dicionários para promover melhor uso e interação entre material pedagógico e aprendiz. 


\section{CAPITULO 5: ANÁLISE DE DADOS}

Nesta pesquisa, estudamos os verbos da língua portuguesa, conforme apresentado no capítulo 3, com vistas à aprendizagem do português do Brasil como segunda língua. O percurso seguido até o momento foi o estudo, principalmente, dos princípios teóricos da lexicografia bilíngue e semibilíngue para analisar as tipologias lexicográficas e, assim, compreender os diferentes tipos de obras em relação ao público-alvo. Além disso, buscamos diretrizes para a aprendizagem do léxico, por meio de dicionário, e selecionamos verbos para compor o Dicverb/PL2 que têm como público-alvo o aprendiz de PSL, falantes da língua inglesa, em seu estágio inicial.

Neste capítulo, será apresentada a análise dos verbos que nos conduziu à elaboração da microestrutura do Dicionário de aprendizagem de verbos do português como segunda língua - Dicverb/PL2. O capítulo está organizado do seguinte modo: i) análise dos significados dos verbos, segundo enunciados relacionados aos 17 contextos selecionados para o Dicverb/PL2; ii) análise sintático-semântica dos verbos e iii) apresentação dos resultados da análise.

\subsection{Análise dos significados dos verbos segundo os contextos}

A análise pormenorizada de 85 verbos do corpus forneceu informações que contribuíram para a tese e para a organização da microestrutura do dicionário de aprendizagem. A análise observou os significados dos verbos considerando o componente gramatical, o componente contextual, o componente conceitual e o componente de saída, para, assim, selecionar e organizar as informações linguísticas e extralinguísticas para oferecer ao aprendiz elementos que sejam úteis para o uso concreto dos verbos utilizados no discurso cotidiano dos brasileiros.

Selecionamos 5 verbos para cada um dos 17 contextos situacionais descritos no Capítulo 3. Os contextos fornecem informações conceituais e físicas que cooperam para a construção do significado e da gramaticalização dos enunciados, conforme a figura da teoria da GDF reproduzida aqui. 


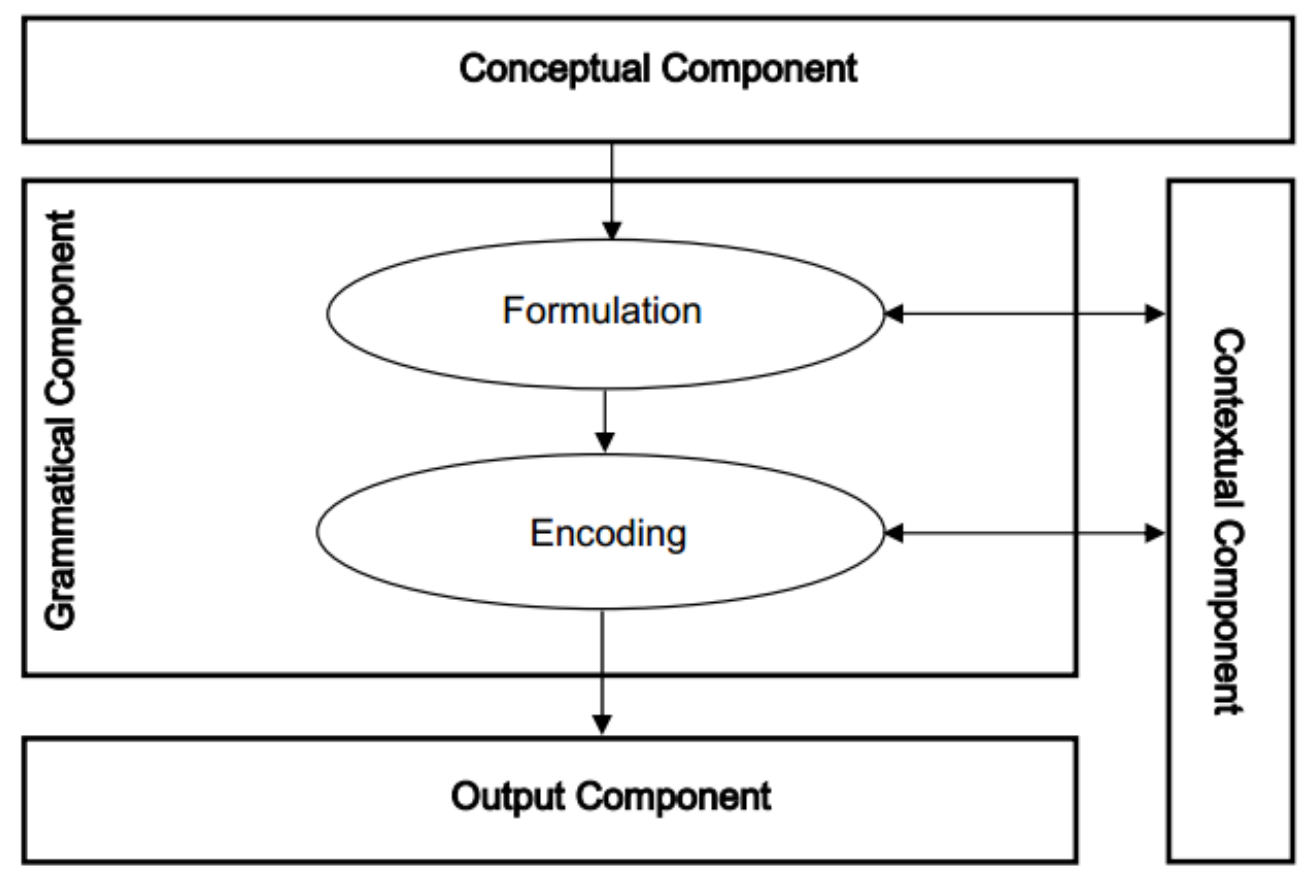

Fonte: (HENGEVELD \& MACKENZIE, 2010, p. 2)

Assim, o verbo vestir, como regra geral, enquadra-se no contexto de vestimentas e indumentárias, pois se refere à ação-processo de colocar roupa em alguém ou em si mesmo; ou usar roupas e acessórios para vestir o corpo ou parte do corpo: Nesse sentido, os enunciados:

(15) Segundo o jornal, aos 45 anos e em boa forma, Jennifer vestiu um mini-vestido de cor laranja.

(16) [No verão], vista-o com roupas leves e ofereça bastante líquido a ele.

são produzidos e compreendidos em contexto que se refere à moda, às regras de etiqueta, à vestimenta apropriada para cada ocasião e para cada estação do ano. Os conceitos são de moda, estação do ano, regras de etiqueta e eventos sociais; o 'cenário' e a 'cena' do evento comunicativo são construídos, e fornecem elementos para a formulação e a compreensão de enunciados, a partir da perspectiva do falante e do ouvinte. Informações contidas no 'cenário', na 'cena' e no conhecimento de mundo dos participantes do evento comunicativo colaboram para a construção e para a compreensão das partes do discurso como número, pessoa, tempo verbal e o léxico pertinente ao contexto. A criatividade humana permite 
que, de acordo com o contexto situacional, o falante atribua outros significados ao verbo vestir, adaptando-o a sua intenção comunicativa. Servem de exemplo:

(17) Vestir a camisa do Sampaio já é uma grande motivação.

Nesse caso, vestir apresenta significado distinto do de colocar ou usar roupa ou acessórios para vestir o corpo ou parte do corpo. O enunciado é produto das informações extralinguísticas, e representa o hábito de jogadores de futebol, em entrevista, demonstrarem perfeito acordo com o time. Assim, o ato de vestir a camisa significa fazer parte da equipe, ter sido contratado para fazer parte daquele time com propósito de beneficiá-lo.

Nesse sentido, apesar de vestiu um mini-vestido e vestir a camisa apresentarem estrutura sintática semelhante, quer dizer mesmo tipo de complemento, $\mathrm{C} 1$, que é nome, concreto, não-animado e faz parte do campo vestuário, os significados das expressões são diferentes. A distinção dos significados é resultado dos componentes conceitual e contextual.

Em vista dessas evidências, exporemos uma tabela com 85 verbos para demonstrar o resultado quantitativo da oscilação dos significados dos verbos diante de contextos diferentes, conforme analisamos. Os significados dos verbos são reciclados à medida que a situação ocorre e os conceitos provêm do 'fundo lexical'. O contexto situacional fornece limites para cada significado, de acordo com a comunicação entre os participantes do evento.

Os 85 verbos seguintes foram analisados com base nas fichas preenchidas, e seguem a metodologia adotada e descrita no Capítulo 3, considerando os 17 contextos que são abordados nesta tese.

A tabela abaixo apresenta a quantidade de significados diferentes identificados durante a pesquisa. 
Tabela 3: quantitativo de significados relacionados aos contextos

\begin{tabular}{|c|c|c|c|}
\hline CONTEXTO SITUACIONAL & VERBOS & $\begin{array}{l}\text { Número de } \\
\text { significados } \\
\text { relacionados } \\
\text { ao contexto }\end{array}$ & $\begin{array}{l}\text { Número de } \\
\text { significados } \\
\text { diferentes } \\
\text { dos } \\
\text { relacionados } \\
\text { ao contexto }\end{array}$ \\
\hline \multirow{5}{*}{$\begin{array}{l}\text { 1) Alimentar } \\
\text { Contextos relacionados à ação, ao estado ou ao processo de } \\
\text { alimentar ou nutrir o corpo com substâncias digeríveis pelo } \\
\text { organismo. }\end{array}$} & 1) Jantar & 01 & +01 \\
\hline & 2) Comer & 02 & +05 \\
\hline & 3) Beber & 01 & +02 \\
\hline & 4) Tomar & 02 & +10 \\
\hline & 5) Alimentar & 01 & +03 \\
\hline \multirow{5}{*}{$\begin{array}{l}\text { 2) Atividades comerciais } \\
\text { Contextos relacionados à ação, ao estado ou ao processo de } \\
\text { atividades de troca, de venda ou de compra de bens, } \\
\text { produtos, mercadorias e serviços. }\end{array}$} & 6) Comprar & 01 & +02 \\
\hline & 7) Vender & 01 & +02 \\
\hline & 8) Pagar & 02 & +03 \\
\hline & 9) Financiar & 01 & +01 \\
\hline & 10)Gastar & 01 & +03 \\
\hline \multirow{5}{*}{$\begin{array}{l}\text { 3) Atividades domésticas } \\
\text { Contextos relacionados à ação, ao estado ou ao processo } \\
\text { que envolvem as atividades, a administração ou a } \\
\text { organização do lar, da família, da vida particular de uma } \\
\text { pessoa. }\end{array}$} & 11)Lavar & 01 & +02 \\
\hline & 12)Cozinhar & 01 & +02 \\
\hline & 13)Limpar & 01 & +07 \\
\hline & 14)Passar & 01 & +11 \\
\hline & 15) Arrumar & 01 & +04 \\
\hline \multirow{5}{*}{$\begin{array}{l}\text { 4) Clima e tempo } \\
\text { Contextos relacionados à ação, ao estado ou ao processo } \\
\text { que envolvem as condições atmosféricas que exercem } \\
\text { influências sobre a vida na Terra, as características } \\
\text { específicas das regiões e as condições meteorológicas. }\end{array}$} & 16)Chover & 01 & $\varnothing$ \\
\hline & 17)Inundar & 01 & $\varnothing$ \\
\hline & 18)Esfriar & 01 & +03 \\
\hline & 19)Secar & 01 & +03 \\
\hline & 20)Esquentar & 01 & +03 \\
\hline \multirow{5}{*}{$\begin{array}{l}\text { 5) Crime e violência } \\
\text { Contextos relacionados à ação, ao estado ou ao processo } \\
\text { que envolvem a transgressão moral ou ética, socialmente } \\
\text { rejeitada, seja por ação, seja por omissão, empregando } \\
\text { força física ou psicológica, passiva de punição pela lei } \\
\text { penal. }\end{array}$} & 21)Bater & 01 & +04 \\
\hline & 22)Matar & 01 & +06 \\
\hline & 23)Roubar & 02 & +02 \\
\hline & 24)Corromper & 01 & +02 \\
\hline & 25)Agredir & 01 & +01 \\
\hline \multirow{5}{*}{$\begin{array}{l}\text { 6) Educação } \\
\text { Contextos relacionados à ação, ao estado ou ao processo } \\
\text { que envolvem o desenvolvimento físico, intelectual, social } \\
\text { e moral do ser humano, que assegure sua formação sócio- } \\
\text { histórico-cultural, seja em ambiente familiar, seja em } \\
\text { ambiente formal. }\end{array}$} & 26)Estudar & 01 & +01 \\
\hline & 27)Ensinar & 01 & +01 \\
\hline & 28) Aprender & 01 & +02 \\
\hline & 29)Reprovar & 01 & +01 \\
\hline & 30)Pensar & 01 & +02 \\
\hline \multirow{3}{*}{$\begin{array}{l}\text { 7) Esporte } \\
\text { Contextos relacionados à ação, ao estado ou ao processo } \\
\text { que envolvem as práticas, individuais ou coletivas, de jogos } \\
\text { e de exercícios físicos, seja com fins de recreação, seja com }\end{array}$} & 31)Jogar & 01 & +03 \\
\hline & 32)Lutar & 01 & +03 \\
\hline & 33)Correr & 01 & +02 \\
\hline
\end{tabular}


fins de condicionamento corporal para benefício da saúde, seja para competições esportivas.

\section{8) Festas e festividades}

Contextos relacionados à ação, ao estado ou ao processo que envolvem reuniões de pessoas com fins recreativos, enquadrando-se às festas familiares, às solenidades civis e às de caráter religioso.

\section{9) Lazer}

Contextos relacionados ao tempo utilizado para o ócio, o descanso e outras atividades prazerosas.

\section{0) Moradia}

Contexto relacionados à ação, ao estado ou ao processo de residir, habitar, viver em barraco, casa, apartamento, mansão ou outro lugar.

\section{1) Profissão e trabalho}

Contextos relacionados à ação, ao estado ou ao processo que envolvem ofício, trabalho, ocupação, atividade profissional em que uma pessoa visa obter recursos financeiros, como remuneração ou salário.

\section{2) Relações sociais}

Contextos relacionados à ação, ao estado ou ao processo que envolvem o convívio entre pessoas ou grupo de pessoas com interesses comuns, que se relacionam com fins particulares, profissionais, familiares, emocionais, de acordo com a cultura e a sociedade local.

\section{3) Saúde e doenças}

Contextos relacionados à ação, ao estado ou ao processo que envolvem as condições físicas e psíquicas, proporcionando o bem-estar, e quando não estão equilibradas, provocam enfermidades, mal, moléstia aos seres vivos, podendo apresentar sintomas.

\section{4) Tabuísmo}

Contextos relacionados à ação, ao estado ou ao processo que envolvem comportamentos, palavras ou expressões consideradas chulas, grosseiras ou ofensivas em determinados contextos sociais.

\begin{tabular}{|c|c|c|}
\hline 34)Ganhar & 01 & +02 \\
\hline 35)Competir & 01 & +02 \\
\hline 36)Comemorar & 02 & $\varnothing$ \\
\hline 37) Alegrar & 01 & +01 \\
\hline 38)Organizar & 01 & +03 \\
\hline 39)Desfilar & 02 & +02 \\
\hline 40)Convidar & 01 & +01 \\
\hline 41)Brincar & 01 & +02 \\
\hline 42)Dançar & 01 & $\varnothing$ \\
\hline 43)Divertir & 01 & +01 \\
\hline 44)Descansar & 01 & +02 \\
\hline 45)Passear & 01 & +02 \\
\hline 46) Alugar & 01 & +01 \\
\hline 47)Reformar & 01 & +02 \\
\hline 48)Morar & 01 & +01 \\
\hline 49) Viver & 01 & +03 \\
\hline 50)Construir & 01 & +02 \\
\hline 51)Trabalhar & 01 & +03 \\
\hline 52)Empregar & 01 & +01 \\
\hline 53)Promover & 01 & +03 \\
\hline 54)Contratar & 01 & +01 \\
\hline 55)Investir & 01 & +01 \\
\hline 56)Casar & 01 & +01 \\
\hline 57)Namorar & 01 & +01 \\
\hline 58)Conviver & 01 & +01 \\
\hline 59)Ficar & 01 & +05 \\
\hline 60)Discutir & 01 & +01 \\
\hline 61)Cuidar & 01 & +03 \\
\hline 62)Adoecer & 01 & $\varnothing$ \\
\hline 63)Internar & 01 & +01 \\
\hline 64)Operar & 01 & +02 \\
\hline 65)Consultar & 01 & +01 \\
\hline 66)Mijar & 01 & +01 \\
\hline 67)Cagar & 01 & +01 \\
\hline 68)Foder & 01 & +01 \\
\hline 69)Arrombar & 01 & +01 \\
\hline 70)Trepar & 01 & +01 \\
\hline 71)Dirigir & 01 & +02 \\
\hline
\end{tabular}




\begin{tabular}{|c|c|c|c|}
\hline \multirow{4}{*}{$\begin{array}{l}\text { Contextos relacionados à ação, ao estado ou ao processo } \\
\text { que envolve movimentação, trajeto, passagens ou } \\
\text { deslocamento em determinado lugar, com utilização ou não } \\
\text { de veículos. }\end{array}$} & 72) Atropelar & 01 & +01 \\
\hline & 73)Engarrafar & 01 & +01 \\
\hline & 74)Pegar & 01 & +05 \\
\hline & 75)Levar & 02 & +04 \\
\hline \multirow{5}{*}{$\begin{array}{l}\text { 16) Vestimentas e indumentárias } \\
\text { Contextos relacionados à ação, ao estado ou ao processo } \\
\text { que envolvem o hábito sociocultural de utilizar roupas e } \\
\text { acessório para vestir o corpo ou partes do corpo. }\end{array}$} & 76) Vestir & 02 & +01 \\
\hline & 77)Experimentar & 01 & +03 \\
\hline & 78)Usar & 01 & +02 \\
\hline & 79) Tirar & 01 & +05 \\
\hline & 80)Colocar & 01 & +01 \\
\hline \multirow{5}{*}{$\begin{array}{l}\text { 17) Viagem } \\
\text { Contextos relacionados à ação, ao estado ou ao processo } \\
\text { que envolvem deslocamentos de um lugar para outro, } \\
\text { relativamente distante, normalmente com finalidade } \\
\text { profissional ou de entretenimento e turismo. }\end{array}$} & 81)Reservar & 01 & +02 \\
\hline & 82) Viajar & 01 & $\varnothing$ \\
\hline & 83)Hospedar & 01 & +03 \\
\hline & 84)Conhecer & 01 & +01 \\
\hline & 85) Visitar & 01 & +02 \\
\hline
\end{tabular}

As informações numéricas contidas nesta tabela demonstram que o somatório dos significados identificados nos $\mathbf{8 5}$ verbos é de 281, distribuídos entre os 17 contextos abordados em nossa pesquisa. Apenas 5 verbos do corpus apresentaram um único significado, segundo os contextos: chover, inundar, dançar, adoecer e viajar.

Os verbos com maior número de significados foram: tomar, com 13 significados; passar, com 12 significados; limpar com 8 significados; matar, com 7 significados; comer, com 7 significados; e pegar, tirar e ficar, com 6 significados cada.

A informação conceitual e contextual, fornecida pelo contexto situacional, associada à experiência de vida do aprendiz, funciona como filtro seletivo. Consequentemente, durante o processo de produção ou de compreensão ocorre a seleção do significado almejado. $\mathrm{O}$ compontente gramatical é ativado, conforme é previsto no sistema top down da GDF. Esses fatos corroboram para a justificativa de que a polissemia é um fato linguístico. No entanto, o discurso real demonstra que o usuário da língua recorre à característica monossêmica dos verbos para a produção e para a compreensão dos significados, favorecida pelas restrições do 'cenário' e da 'cena' em que os enunciados ocorrem.

Foram identificados mais de um significado em um mesmo contexto, como no verbo roubar em contexto referente a crime e a violência: 
(18) Ladrões que roubaram banco em MT abandonam veículo e

(19) Mulher que roubou bebê no RS é internada para tratamento psiquiátrico.

O contexto de crime e violência atua como filtro inicial de significado, direcionando os participantes do evento. O componente conceitual e o componente contextual participam na diferenciação dos significados, pelas informações dos elementos que compõem o ‘cenário' e a 'cena', em que as características instituição financeira, nome, concreto, não animado estabelecem oposição às características criança recém-nascida ou de poucos meses, nome, concreto, animado, humano. As informações pré-linguísticas de que um bebê recém-nascido não porta dinheiro, mas é um ser humano indefeso, por exemplo, excluem o significado de apropriar-se de bem alheio, mediante violência, ameaça ou fraude. Informações do contexto situacional, que não estão explicitas no enunciado, como o fato de o bebê ser recém-nascido e estar na maternidade, cooperam para o significado de sequestro, em que a mulher levou consigo o bebê de modo ilegal.

Como demonstrado, somente o conhecimento sintático da língua portuguesa não é suficiente para questões como as apresentadas nos parágrafos anteriores, sendo necessário ao aprendiz atuar em conjunto com o componente conceitual e o componente contextual para chegar também ao conhecimento semântico. Um enunciado, como Mulher que roubou homem no RS, com estrutura sintática semelhante ao enunciado Mulher que roubou beb $\hat{\boldsymbol{e}}$ no $R S$, apresenta significado diferente. O conceito de "apropriou-se de bem alheio, mediante a violência, ameaça ou fraude", representado pelo item lexical roubar é produto da informação pré-linguística desse verbo associada às informações pré-linguísticas do item lexical homem, em que no universo conceitual pode portar bem ou dinheiro, diferentemente do conceito representado pelo item lexical bebê.

Desse modo, verifica-se que a natureza criativa do ser humano o permite fazer modificações semânticas dos itens lexicais para a produção e para a compreensão dos enunciados, adaptando léxico e gramática de acordo com a intenção comunicativa, o contexto situacional e a comunidade de fala.

Observado o fato de que as informações extralinguísticas colaboram para o significado na produção e na compreensão dos enunciados, apresentaremos a análise de verbos, na perspectiva sintático-semântica. 


\subsection{Análise sintático-semântica dos verbos}

Com base nas informações contidas nas fichas e nas teorias da Lexicologia e da Lexicografia, organizamos os dados em uma segunda estrutura de análise. A seguir, apresentaremos uma amostra das análises que contribuíram para a elaboração da proposta de dicionário de aprendizagem de PSL.

Lembramos que os verbos em análise estão em negrito, os complementos do verbo estão em itálico e os complementos internos dos verbos estão sublinhados. As setas vermelhas indicam o tipo de verbo, se de ação, ação-processo, processo ou estado. As setas pretas e azuis indicam as especificidades dos complementos. Na sequência, são apresentados o significado do verbo de acordo com o contexto do enunciado.

\section{1) Análise semântico-sintática do verbo tomar}

\section{a) Contexto alimentação}<smiles>[14CH3]</smiles>

(20) Ele toma refrigerante todos os dias no lanche da escola e acompanhando as refeições nos $\downarrow$ fins de semana. $\sqrt{\text { (tribunahoje) }}$

$\begin{array}{ll}\text { agente } & \mathrm{C} 1 \\ \text { pronome } & \text { nome } \\ \text { concreto } & \text { concreto } \\ \text { animado } & \text { não-animado } \\ \text { humano } & \text { não-contável } \\ & \text { líquido }\end{array}$

Significado de tomar em (20) = beber, ingerir bebidas.

Ele $=$ complemento $(\mathrm{C} 1) \rightarrow$ nome, concreto, não-animado e sem preposição.

$\underline{\text { Refrigerante }}=$ complemento externo $\rightarrow$ agente, nome, concreto, animado e humano. 


\section{ação \\ 个}

(21) Os participantes tomam sopa como entrada para a refeição. (gshow.globo)

$\begin{array}{ll}\text { agente } & \text { C1 } \\ \text { nome } & \text { nome } \\ \text { concreto } & \text { concreto } \\ \text { animado } & \text { não-animado } \\ \text { humano } & \text { pastoso/ líquido + sólidos }\end{array}$

Significado de tomar em (21) = ingerir (alimentos líquidos, pastosos ou líquidos contendo partes sólidas)

Os participantes $=$ complemento $(\mathrm{C} 1) \rightarrow$ nome, concreto, não-animado, sem preposição $\underline{\text { Sopa }}=$ complemento externo $\rightarrow$ agente, nome, concreto, animado e humano

\section{b) Clima e tempo}

Ação-processo

(22) Filas e trânsito tomam muito tempo que poderia ser aproveitado para outras atividades.

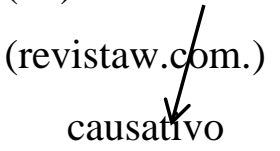

nome

concreto

não-animado
$\mathrm{C} 1$

nome

concreto

não-animado

Significado de tomar em (22) = consumir o tempo

$\underline{\text { Tempo }}=$ complemento $(\mathrm{C} 1) \rightarrow$ nome, concreto e não-animado

Filas e trânsito $=$ complemento externo $\rightarrow$ causativo, nome, concreto, não-animado 


\section{c) Crime e violência}

Ação-processo

(23) $O$ ladrão tomou a bolsa da mulher e saiu correndo no meio da multidão.

agente

C1

$\mathrm{C} 2$

afetado

nome

nome

nome

concreto

concreto

concreto

não-animado humano

animado

proprietário do bem

humano

Significado de tomar em (23) = roubar

$\underline{\text { A bolsa }}=$ complemento $(\mathrm{C} 1) \rightarrow$ nome, concreto e não-animado

$\underline{\text { da mulher }}=$ complemento $(\mathrm{C} 2) \rightarrow$ nome, concreto humano e proprietário do bem

O ladrão $=$ complemento externo $\longrightarrow$ agente, nome, concreto, animado e humano

Ação-processo

(24) $O$ árbitro tomou um soco $\underset{\Downarrow}{\Downarrow}(\varnothing)$ após a partida. (saraivareportes.com)

\section{beneficiário $\quad \mathrm{Cl}$}

nome nome

concreto abstrato de ação

animado não-animado

humano

Significado de tomar em $(24)=$ receber golpes

$\underline{\mathrm{Um} \text { soco }}=$ complemento $(\mathrm{C} 1) \rightarrow$ nome, abstrato de ação e não-animado

$(\varnothing)=$ complemento $(\mathrm{C} 2) \rightarrow$ não explícito no enunciado, mas existente no evento comunicativo. (de alguém)

$O$ árbitro $=$ complemento externo $\rightarrow$ beneficiário, nome, concreto, animado e humano 


\section{Ação-processo}

(25) Rebeldes tomam cidade perto da capital (g1.globo.com)

$\begin{array}{ll}\Downarrow & \frac{}{\mathrm{C} 1} \\ \text { agente } & \text { nome } \\ \text { nome } & \text { concreto } \\ \text { concreto } & \text { não-animado } \\ \text { animado } & \text { locativo }\end{array}$

Significado de tomar em $(25)=$ invadir

$\underline{\text { Cidade }}=$ complemento $(\mathrm{C} 1) \rightarrow$ nome, concreto, não-animado e locativo

Rebeldes $=$ complemento externo $\longrightarrow$ agente, nome, concreto, animado e humano

d) Educação

Ação-processo

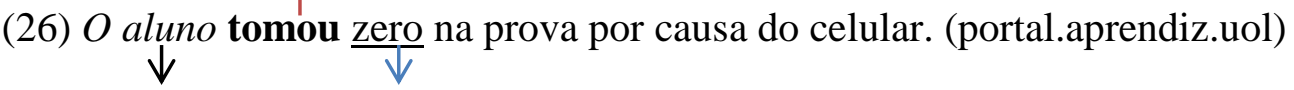
beneficiário $\quad \mathrm{C} 1$

nome nome

concreto concreto

animado não-animado

humano

Significado de tomar em $(26)=$ receber por merecimento

$\underline{\text { Zero }}=$ complemento $(\mathrm{C} 1) \rightarrow$ nome, concreto, não-animado

$O$ aluno $=$ complemento externo $\longrightarrow$ beneficiário, nome, concreto, animado e humano

e) Profissão e trabalho

suporte

(27) Fernanda e Amanda tomam conta da administração e do marketing do negócio. (veja comer\&beber)

agente

C1

nome

nome

concreto

abstrato de estado

animado

não-animado

humano 
Significado de tomar em (27) = administrar, cuidar

$\underline{\text { Conta da administração }}=$ complemento $(\mathrm{C} 1) \rightarrow$ nome, abstrato de estado, não-animado

Fernanda e Amanda = complemento externo $\longrightarrow$ agente, nome, concreto, animado, humano.

\section{f) Saúde e doenças}

ação

(28) Não tome remédio sem o conhecimento de seu médico. (revista de saúde pública)
C1
nome
concreto
não-animado

Significado de tomar em (28) = ingerir medicamentos por via oral ou não

$\underline{\text { Remédio }}=$ complemento $(\mathrm{C} 1) \rightarrow$ nome, concreto e não-animado

Complemento externo $\longrightarrow$ não explícito diretamente no texto, mas recuperado pela desinência verbal.

processo

(29) Verão 2013: tôme sol na medida certa. (revistamdmulher)
$\stackrel{*}{c} 1$
nome
concreto
não-animado

Significado de tomar em (29) = absorver luz solar por se expor ao sol

$\underline{\text { Sol }}=$ complemento $(\mathrm{C} 1) \rightarrow$ nome, concreto e não-animado

Complemento externo $\rightarrow$ não explícito diretamente no enunciado, mas recuperado pela desinência verbal. 


\section{g) Trânsito e transporte}

ação

(30) Estudante toma três ônibus diariamente entre Igarassu e Jaboatão, Grande Recife. $\begin{array}{cl}\text { (globo.com) } & \searrow \\ \text { agente } & \mathrm{C} 1 \\ \text { nome } & \text { nome } \\ \text { concreto } & \text { concreto } \\ \text { animado } & \text { não-animado } \\ \text { humano } & \end{array}$

Significado de tomar em $(30)=$ embarcar

$\underline{\text { Tres ônibus }}=$ complemento $(\mathrm{C} 1) \rightarrow$ nome, concreto, não-animado

Estudante $=$ complemento externo $\rightarrow$ agente, nome, concreto, animado e humano

O verbo tomar apresentou 13 significados distintos dentro de contextos diferentes entre os abordados nesta pesquisa. Foram encontradas ocorrências em outros contextos, porém não os descrevemos por estarem fora do recorte metodológico. No contexto de alimentação, identificamos 2 significados distintos, ingerir bebidas (alcólicas ou não) e ingerir alimentos pastosos ou líquidos com partes sólidas para nutrição do corpo. A distinção entre os significados dá-se pelas informações conceituais representadas por itens linguísticos, como refrigerante e sopa, que enunciam o que o falante deseja, de acordo com o evento comunicativo e o contexto situacional e não pelo tipo do complemento $\mathrm{C} 1$, em vista de as duas ocorrências do verbo apresentarem como complementos: nome, concreto, nãoanimado, sem preposição.

No contexto referente a clima e tempo, o significado do verbo tomar ocorre correlacionado com o conceito de minutos decorridos, em que o tempo cronológico é consumido em filas e em trânsito, típico de cidades urbanas. Nesse caso, o verbo exerce uma ação que afeta o complemento $\mathrm{C} 1$, por isso é classificado como ação-processo. Os itens lexicais fila, trânsito e tempo são selecionados pelo verbo para completar o significado consumo do tempo, ativando o conhecimento de mundo do indivíduo em relação à vida moderna, em que os centros urbanos são mais populosos, gerando as filas e o trânsito intenso. 
As ocorrências do verbo tomar relacionadas ao contexto de crime e violência selecionam três tipos de complementos: externo, que é agente da ação de roubar bem alheio; complemento interno $\mathrm{C} 1$, sem preposição, que indica o elemento que foi roubado e o complemento interno $\mathrm{C} 2$, com preposição, que indica o elemento afetado pelo agente. A preposição DE é a selecionada pelo verbo no $\mathrm{C} 2$, atua como indicador de possuidor. Os itens lexicais ladrão, bolsa e mulher são os selecionados pelo verbo para representar os conceitos complementares do enunciado, tanto para produção como para compreensão, diante da interação entre os participantes, 'cenário' e ‘cena' dos eventos comunicativos.

Outro significado do verbo tomar, no enunciado (24), no contexto de violência, é o de receber golpes, murros, socos de alguém. Neste sentido, o verbo seleciona complemento externo diferente dos já citados no contexto de crime e violência no enunciado (23). $\mathrm{O}$ complemento externo possui características de beneficiário, nome, concreto, animado, humano. O complemento interno selecionado apresenta como características nome, abstrato de ação e não-animado. E o segundo complemento exigido pelo verbo não está explícito no enunciado, mas existente no evento comunicativo e é recuperado pelo 'cenário' e pela 'cena'. Fatores extralinguísticos representados pelo item lexical árbitro associados à ideia de encerramento do jogo contribuem para que o enunciado (24) represente o evento comunicativo que descreve ato violento. O conceito de árbitro engloba o conceito de que juiz da partida de futebol não participa da disputa direta da bola dentro do campo. Assim sendo, ele não disputa a bola do jogo, por isso o risco de ser afetado por eventuais socos, chutes ou trombadas, que são previsíveis nos jogos de contato como o futebol, que não são considerados atos violentos entre os jogadores, dentro de limites convencionais da partida. Além disso, o fato de o tempo do jogo ter se esgotado exclui o conceito de acidente, indicando assim ação de violência. Os itens lexicais árbitro, soco e partida se interrelacionam com os conceitos, o contexto e a estrutura linguística por meio do elo tomar.

No enunciado (25), também no contexto de crime e violência, a seleção dos itens lexicais rebeldes e cidade pelo verbo contribuem para a descrição do significado de invadir. O complemento externo, rebelde, é agente, nome, concreto, animado e humano, representando que tipo de elemento pode exercer a ação de invadir. E o complemento interno é representado pelo item lexical cidade, indicando lugar que pode ser invadido.

Como observado, o verbo seleciona os elementos conceituais relacionados ao ‘cenário' e à ‘cena' para complementar o significado específico que os participantes desejam 
expressar. A delimitação do contexto de crime e violência restringe significados possíveis para o verbo tomar.

O significado do verbo tomar, no contexto de educação, é o de receber por recompensa ou por castigo algo por merecimento. O complemento externo selecionado é beneficiário, nome, concreto, animado e humano. O complemento interno selecionado é do tipo (C1) nome, concreto, não-animado. A contribuição do contexto indica que dentro do sistema de educação escolar o estudante é avaliado, por conseguinte, o item lexical zero representa o conceito de desempenho negativo.

No contexto de saúde e doenças, foram observados três significados em nossos dados, o de se expor ao sol para absorver luz solar, o de ingerir medicamentos por via oral, ou outro meio, e o de fazer higiene pessoal com o uso de água e sabonete. Nesses enunciados, o verbo seleciona como complemento interno um nome, concreto, não-animado e sem preposição, complemento tipo $\mathrm{C} 1$. No enunciado, (28) Não tome remédio sem o conhecimento de seu médico, o significado diferencia-se do contexto de alimentação, pois reporta o sentido de inserir no corpo substância para tratamento relacionado à cura ou ao bem estar da pessoa, podendo ser ingerido via oral ou não. Por outro lado, no enunciado (29) Verão 2013: tome sol na medida certa, relaciona-se à saúde e a doenças por destacar que a exposição ao sol é fundamental, mas por tempo determinado. Nesse último significado, o componente conceitual atua fornecendo conteúdo extralinguístico como a cultura e a geografia brasileira, além das informações biológicas e químicas do sol nos seres.

Sendo assim, o verbo tomar apresenta significados diferentes. Ocorre como verbo de ação, de ação-processo e de processo nos exemplos analisados.

Destacamos ainda a ocorrência do verbo tomar como tabu na sociedade brasileira ( $A$ torcida mandou o juiz tomar no c...), de uso frequente em estádios ou campos de futebol, conforme análise do 'cenário' e da 'cena' em que o enunciado ocorre. Os enunciados recolhidos ilustam o caráter polissêmico do verbo tomar, e, em cada ocorrência, há características que delimitam os significados, considerando componente conceitual, o componente contextual e o componente gramatical, para que no discurso real apresente um significado específico. 
2) Análise semântico-sintático do verbo comer:

\section{a) Alimentação}

Ação

(31) Lugar para comer sem pressa, o Guamaré mantém um atendimento simpático, garantido por Nádia e Risima - respectivamente, mulher e irmã do dono. (Rvejacomer\&beber)

Significado de comer em (33) = alimentar-se (genérico)

$(\varnothing)=$ complemento externo ausente

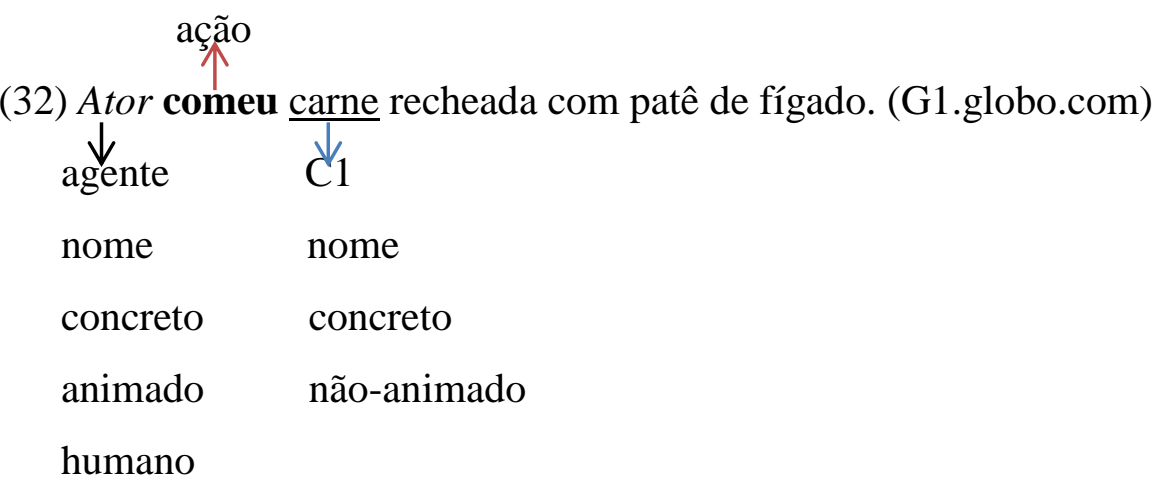

Significado de comer em (34) = alimentar-se, ingerir alimento sólido

$\underline{\text { Carne }}=$ complemento $(\mathrm{C} 1) \rightarrow$ nome, concreto e não-animado

Ator $=$ complemento externo $\rightarrow$ agente, nome, concreto, animado e humano

\section{b) Atividades domésticas}

$$
\text { Ação-processo }
$$

(33) A traça comeu a roupa que estava no armário. (gazetaonline.globo)

$\begin{array}{ll}\text { agente } & \mathrm{C} 1 \\ \text { nome } & \text { nome } \\ \text { concreto } & \text { concreto } \\ \text { animado } & \text { não-animado } \\ \text { não-humando } & \end{array}$

Significado de comer em (35) = danificar, destruir

$\underline{\text { A roupa }}=$ complemento $(\mathrm{C} 1) \rightarrow$ nome, concreto, não-animado 
A traça $=$ complemento externo $\rightarrow$ agente, nome, concreto, animado, não-humano

\section{c) Educação}

ação-processo

(34) Porque o filho inventa grafias, 'come' letras - escrevendo boneca apenas com 'bnc', por exemplo. (Rcrescer)

$\mathrm{C} 1$

$\begin{array}{ll}\text { agente } & \text { nome } \\ \text { concreto } & \text { concreto } \\ \text { animado } & \text { não-animado } \\ \text { humano } & \end{array}$

Significado de comer em (36) = eliminar, omitir

$\underline{\text { Letras }}=$ complemento $(\mathrm{C} 1)$ nome, concreto, não-animado, determinado, sem preposição.

$O$ filho $=$ complemento externo $\rightarrow$ agente, nome, concreto, animado, humano.

\section{d) Lazer}

Ação-processo

(35) Ganha o jogo quem comer todas as peças do adversário.

$\begin{array}{ll}\downarrow & \longleftarrow \\ \text { agente } & \text { nome } \\ \text { pronome } & \text { concreto } \\ \text { concreto } & \text { não-animado } \\ \text { animado } & \\ \text { humano } & \end{array}$

Significado de comer em (37) = eliminar, omitir

$\underline{\text { Todas as peças }}=$ complemento-(C1) nome, concreto, não-animado, sem preposição.

Quem $=$ complemento externo $\rightarrow$ agente, nome, concreto, animado, humano. 


\section{e) Profissão e trabalho}

\begin{tabular}{ll}
\multicolumn{2}{c}{ ação-processo } \\
(36) Inflação acelerada come salário do trabalhador neste ano. (Sipea) \\
$\downarrow$ & complemento \\
causativo & nome \\
nome & abstrato de ação \\
abstrato de processo & não-animado \\
não-animado &
\end{tabular}

Significado de comer em (38) = dilapidar, consumir.

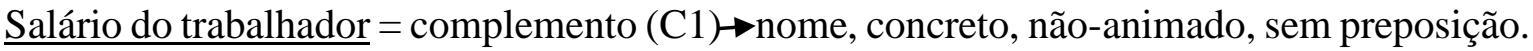
Inflação acelerada $=$ complemento externo $\rightarrow$ causativo, nome, abstrato de processo, nãoanimado.

\section{f) Tabuísmo}<smiles></smiles>

(37) Seu Jorge, já comeu uma loira? (Film. E ai, comeu?)

complemento
nome
concreto
animado
humano

Significado de comer em (39) = copular, possuir sexualmente.

$\underline{\text { Uma loira }}=$ complemento $(\mathrm{C} 1) \rightarrow$ nome, concreto, animado, humano.

$($ você) Jorge $=$ complemento externo $\rightarrow$ agente, nome, concreto, animado, humano

O verbo comer nos 7 enunciados analisados, comportou-se como verbo de ação ou de ação-processo. Na maioria das ocorrências, o verbo comer selecionou complemento do tipo $\mathrm{C} 1$, quer dizer, sem preposição. As características frequentes dos complementos selecionados, C1, são nome, concreto, não-animado. Porém, identificamos a ocorrência de um $\mathrm{C} 1$ animado e humano no enunciado (37). O complemento externo comum a esse verbo 
apresenta como característica ser agente, nome, concreto, animado e humano. No entanto, observamos a ocorrência de complemento externo, representado pelo item lexical inflação, com as características de abstrato de processo, não-animado e não-humano.

No contexto de alimentação, quando o verbo comer não é acompanhado de complemento externo e nem de complemento interno, atribui-se característica de ação genérica, que faz parte do cotidiano das pessoas e não de um evento específico, expressando que alguém ou algo que executa a ação de ingerir alimento sólido, introduzindo-o pela boca, mastigando-o e engolindo-o.

A ocorrência do verbo comer, no contexto de atividades domésticas, apresenta o significado de danificar, que é construído em conjunto com o conceito dos itens lexicais traça, roupa e armário. Diante dos elementos que compõem o 'cenário' e a 'cena', os participantes do evento comunicativo selecionam o verbo, que, por sua vez, seleciona os elementos que o acompanharam para expressar o significado almejado. A seleção de traça, no contexto de atividades domésticas, exclui o significado de alimentação, enfatizando a característica desse animal como ser que destrói, que danifica algo e não a de ser que está alimentando-se da substância localizada nas roupas. O ‘cenário' e a 'cena' atuam fornecendo informações que são consideradas no momento de produção e compreensão dos enunciados.

No enunciado (36), Porque o filho inventa grafias, 'come' letras - escrevendo boneca apenas com 'bnc', por exemplo, apesar de o complemento externo ser agente, nome, concreto, animado e humano, o complemento interno selecionado pelo verbo apresenta como característica nome, concreto, não-animado, que não faz parte das substâncias próprias para alimentação. Essa informação faz parte do conhecimento pré-linguístico que orienta os participantes do evento a excluírem o significado de se alimentar e a buscarem significados relacionados à educação mediante ao contexto situacional. É um processo semelhante ao que ocorre no enunciado (37) Ganha o jogo quem comer todas as peças do adversário, no contexto relacionado a lazer.

No contexto de profissão e trabalho, o falante amplia o significado do verbo comer, por meio de recurso metafórico, apresentando complemento externo que não é próprio de comer. A característica de não-animado e abstrato de processo não são comuns do complemento externo desse verbo. A construção do significado é obtida em cooperação com o conhecimento pré-linguístico e o conhecimento linguístico, que é comum aos dados analisados, descritos pela GDF. 
Ainda como relação ao verbo comer, destacamos a influência sociocultural como elemento cooperador significativo na produção e na compreensão do enunciado (39) Seu Jorge, já comeu uma loira? No discurso, o falante utiliza como complemento interno do verbo elemento animado e humano, que, em contexto situacional e cultural, gera o significado de copular, possuir sexualmente.

Cada ocorrência consiste em uma única unidade conceptual no contexto linguístico, situacional e cultural, porque o verbo contém um conjunto de características disponíveis no sistema linguístico virtual e, no contexto, ocorre a combinação necessária para o significado contido em cada enunciado.

3) Análise sintático-semântica do verbo matar:

a) Alimentação

ação

(38) Menine mata fome de jornalistas na chegada de Honduras a Porto Feliz com pão e frutas. (globoesporte)

$\begin{array}{ll}\text { agente } & \mathrm{C} 1 \\ \text { nome } & \text { nome } \\ \text { concreto } & \text { abstrato de estado } \\ \text { animado } & \text { não-animado } \\ \text { humano } & \end{array}$

Significado de matar em (38) = alimentar

$\underline{\text { Fome }}=$ complemento $(\mathrm{C} 1) \rightarrow$ nome, abstrato de estado e não-animado

Menino $=$ complemento externo $\longrightarrow$ agente, nome, concreto, animado e humano. 
b) Crime e violência

(39) Grupo armado mã̃o

(39) Grupo armado mata PM e resgata traficante de hospital em Niterói. (extra.globo)

$\begin{array}{ll}\text { agente } & \downarrow_{1} 1 \\ \text { nome } & \text { nome } \\ \text { concreto } & \text { concreto } \\ \text { animado } & \text { animado } \\ \text { humano } & \text { humano }\end{array}$

Significado de matar em (39) = assassinar, tirar a vida de alguém

$\underline{\mathrm{PM}}=$ complemento $(\mathrm{C} 1) \rightarrow$ nome, concreto, animado e humano

Grupo armado $=$ complemento externo $\rightarrow$ agente, nome, concreto, animado e humano.

\section{c) Esporte}

$$
\text { ação }
$$

(40) Alexandre Pato mata a bola no peito e invade a área palmeirense. (placar.abril)

$\begin{array}{ll}\text { agente }^{\downarrow} & \mathbb{C}_{1} \\ \text { nome } & \text { nome } \\ \text { concreto } & \text { concreto } \\ \text { animado } & \text { não-animado }\end{array}$

humano

Significado de matar em (42) = amortecer o impacto

$\underline{\text { A bola }}=$ complemento $(\mathrm{C} 1) \longrightarrow$ nome, concreto e não-animado

Alexandre Pato $=$ complemento externo $\rightarrow$ agente, nome, concreto, animado e humano

\section{d) Profissão e trabalho}

$$
\text { ação (pronominal) }
$$

(41) Não se mate de trabalhar tentando ficar rico. (jornalbomdiars)

Significado de matar em $(41)=$ Sacrificar-se 
$\mathrm{Se}=$ complemento $(\mathrm{C} 1) \rightarrow$ pronome, representando a si mesmo (nome, concreto, animado) Não explícito no enunciado (você) complemento externo: agente, nome, concreto, animado e humano

\section{e) Relações sociais}

\section{Ação-processo}

(42) O papa Francisco afirmou que "as palquras matam" e recomendou que as pessoas não insultem umas as outras. (noticias.uol.) agente

$$
\begin{aligned}
& \text { nome } \\
& \text { concreto } \\
& \text { não-animado }
\end{aligned}
$$

Significado de matar em (44) = causar sofrimento a; afligir, ferir

Complemento interno = não está explícito diretamente por meio de léxico, mas depreendido pelo contexto situacional (nome, concreto, animado, humano)

As palavras $=$ complemento externo $\rightarrow$ agente, nome, concreto, não-animado

\section{f) Saúde e doença}

ação-processo

(43) Ebola já matou mais de 1.000 na África, diz OMS. (g1.globo)

causativo

nome

abstrato de estado

não-animado

Significado de matar em (43) = contribuir para que (alguém ou algo) morra; levar à morte, acarretar a destruição ou mortandade de

Complemento $(\mathrm{C} 1)$ = não explícito no enunciado, mas recuperado pelo contexto situacional ('pessoas', nome, concreto, animado, humano)

Ebola $=$ complemento externo $\rightarrow$ causativo, nome, abstrato de estado, não-animado 
Identificamos a ocorrência do verbo matar em 6 contextos distintos, dos 17 contextos norteadores de nossa pesquisa. Dos 6 enunciados analisados, 3 apresentaram como complemento externo ser agente, nome, concreto, animado e humano. Em 2 casos, o complemento externo não é animado, sendo causativo em 1 caso. $O$ verbo também se comportou como pronominal no enunciado (41). Nos enunciados analisados, o verbo seleciona complemento do tipo $\mathrm{C} 1$, sem preposição.

O significado de matar frequentemente se relaciona ao contexto de crime e violência. As 'cenas' descritas nessa acepção, normalmente, são compostas por agressor, vítima, armas. Consequentemente, o verbo matar seleciona um item lexical que represente o conceito e alguém ou algo que possa exercer a ação-processo de tirar a vida de um ser vivo. Assim, no contexto sociocultural, o complemento externo tem como características mais comuns de agente, nome, concreto, animado. E nos casos passíveis de pena legal do Direito Civil, a característica de humano é identificada tanto para o complemento externo como para o complemento interno. Quer dizer, valores culturais e sociais são considerados no momento pré-linguístico à produção e à compreensão do enunciado.

Entretanto, observamos que outros tipos de agente são selecionados pelo verbo para completar significados distintos, como o que ocorre no contexto de saúde e doenças. O complemento externo nesse contexto é causativo, nome, abstrado de ação e não-animado, configurando elemento que provoca o efeito de mudar o estado de algo ou alguém por meio de um processo. A doença, ebola, desencadeia processo degenerativo nas pessoas causando a morte, conforme analisado no enunciado (43). Nesse significado, o verbo seleciona como $\mathrm{C} 1 \mathrm{um}$ item lexical que representa o conceito de ser vivo, quer dizer: animado. O enunciado (43) Ebola já matou mais de 1.000 na África, diz OMS explicita de modo indireto o complemento interno diretamente por meio de item lexical específico, mas o C1 é recuperado pelo contexto situacional.

No contexto relacionado a esporte, o verbo seleciona como $\mathrm{C} 1$ um elemento não animado. Essa seleção exclui o conceito de retirar a vida de algum ser, conduzindo a produção e a compreensão do enunciado para outro significado. O contexto situacional fornece infomações pré-linguísticas que ativam o conhecimento de mundo dos participantes do evento comunicativo. Assim, os itens lexicais Alexandre Pato, bola e peito atuam, em conjunto com o 'cenário' e a 'cena', como cooperadores para o significado de amortecer o impacto, identificado no enunciado (40). É um significado típico do verbo matar em partidas 
de futebol, esporte representativo da cultura brasileira, conforme constatamos em notícias sobre o esporte.

A ocorrência do verbo matar, relacionada ao contexto de relações sociais, diferenciase do contexto de crime e violência. Naquele caso, de acordo com o enunciado (42), o agente não é animado, porém afeta outro nome, concreto, animado e humano, provocando sofrimento psicológico. Esse significado está intimamente relacionado a fatores sociais e culturais, pois o limite de algo que pode afligir alguém varia de acordo com a cultura e a sociedade, limite que é aprendido no convívio com a comunidade de fala, na imersão.

\subsection{Conclusões da análise.}

Os dados revelaram que as operações sintático-semânticas, que descrevem verbos como de estado, de ação, de processo, de ação-processo e como verbo suporte, em conjunto com as informações morfossintáticas, que descrevem número, pessoa, tempo e modo dos verbos, são produtos de fatores pré-linguísticos e linguísticos. O componente conceitual e o componente contextual atuam diretamente no componente gramatical, conforme esclarecem Hengeveld e Mackenzie (2008, 2010). Os verbos, em consonância com a ordem de distribuição dos elementos estabelecida pela estrutura da língua portuguesa, selecionam itens lexicais que completam o significado adequado ao contexto situacional, considerando os conceitos e a cultura da comunidade de fala.

A interação verbal é composta pelos componentes conceitual, contextual, gramatical e de saída, em que se identifica a cooperação entre todos os componentes para o êxito da comunicação entre os participantes do evento. Assim, a interação ocorre em organização hierárquica, de cima para baixo (top-down), conforme descrita pela teoria da GDF e ilustrada pelos dados analisados.

A funcionalidade do componente contextual evidenciou-se durante a análise dos dados, pois esse componente coopera com o componente gramatical, convertendo as representações pragmáticas e semânticas em morfossintática e fonológica. Assim, os aspectos teóricos que apresentamos no segundo capítulo desta tese, associados às análises dos dados, corroboram para a inclusão do componente contextual nas obras lexicográficas, pois contribuem para a produção e para a compreensão dos significados, que são produzidos em contextos específicos. 
Desse modo, texto e discurso são construídos por meio de invocação dos aspectos relevantes do contexto, características importantes no uso da linguagem, por oferecerem oportunidades ao falante para criar e adaptar os verbos, utilizando o sistema linguístico segundo suas intenções comunicativas, conforme Connolly (2007) e Cornish (2009).

Assim sendo, o Dicverb/PL2, como fonte de informações de língua e de cultura para os aprendizes de PSL, oferecerá meios que deem significados ao usuário no processo de aprendizagem da língua-alvo para usar os verbos de modo eficiente, em contextos situacionais e culturais básicos, existentes na cultura brasileira, e não somente o contexto linguístico.

\subsection{Síntese do capítulo}

Neste capítulo, apresentamos uma amostra das análises feitas, seguindo as diretrizes delineadas pela metodologia adotada. Analisamos o aspecto contextual e aspectos sintáticosemânticos que demonstraram a interação entre o componente conceitual, o componente contextual e o componente gramatical. O recorte relacionado aos 17 contextos orientou a seleção de significados, que entendemos ser essenciais ao aprendiz de PSL em fase inicial de aprendizagem.

Por conseguinte, as reflexões sobre as teorias linguísticas, os estudos referentes às tipologias lexicográficas, as análises dos dados coletados e a nossa experiência de docência em PSL, nos orientaram para a elaboração da proposta do dicionário de aprendizagem de verbos do português como segunda língua, que apresentaremos no próximo capítulo. 


\section{CAPÍTULO 6 - PROPOSTA PARA DICIONÁRIO DE APRENDIZAGEM DE PSL}

A Universidade de Brasília, como pioneira na criação do Curso de Letras Português do Brasil como Segunda Língua - PBSL, tem atuado como um importante polo na formação de professores e pesquisadores de português como L2 e, não menos, de professores como LE. Na pesquisa que contempla os conhecimentos da Lexicologia, da Lexicografia e da Terminologia, destaca-se o Centro de Estudos Lexicais e Terminológicos, Centro Lexterm, que, pela linha de pesquisa Léxico e Terminolgia do Programa de Pós-graduação da Universidade de Brasília - PPGL/UnB, oferece os meios para a formação de pesquisadores em L2, como se apresenta nesta pesquisa.

Assim, neste capítulo, apresentamos o produto Proposta de um dicionário de aprendizagem de verbos do português do Brasil como segunda língua. A proposta tem fundamentação teórica da gramática do léxico e aplica esses conhecimentos à lexicografia pedagógica, em conexão com os avanços tecnológicos, por isso, o dicionário é informatizado. A elaboração da proposta foi executada em etapas, como veremos a seguir.

\subsection{A proposta do Dicionário de aprendizagem de verbos do português do Brasil como segunda língua - Dicverb/PL2}

A proposta do Dicionário de aprendizagem de verbos do português do Brasil como segunda língua - Dicverb/PL2, para aprendizes em fase inicial de aprendizagem, visa a oferecer conteúdo linguístico e extralinguístico sobre verbos ao aprendiz para auxiliá-lo no processo de aprendizagem de verbos do português do Brasil como L2.

O dicionário segue uma estrutura em vista do público-alvo, o aprendiz estrangeiro, falante da língua inglesa como primeira língua - L1- ou como língua estrangeira - LE -, residente no Brasil, adulto, com mais de 18 anos, com escolarização equivalente ao Ensino Médio no sistema de educação brasileiro e em fase inicial de aprendizagem do português do Brasil.

A proposta enquadra-se nos dicionários semibilíngues, como tipo de obra lexicográfica em que a língua portuguesa é a língua de partida, e a língua inglesa é a língua de chegada, português-inglês (L2 $\rightarrow \mathrm{L} 1 / \mathrm{LE})$. A metalexicografia apresenta-se, prioritariamente, na língua portuguesa, mas faz parte da estrutura itens lexicais 
correspondentes e versões dos exemplos que ilustram o uso dos verbos na língua inglesa. As versões são elaboradas com ênfase no aspecto conceitual.

O Dicionário informatizado, semibilíngue, português-inglês, que elaboramos será disponibilizado no endereço eletrônico www.dicionariodeverbos.com.br para consultas online e poderá ser acessado gratuitamente por notebooks, smartphones, tablets e demais dispositivos com acesso à internet.

Para criar o aplicativo do Dicverb/PL2, desenvolvemos uma ferramenta para armazenar os dados e, assim, compor o banco de dados. Utilizamos o sistema MySQL - My Structured Query Language que permite armazenar, gerenciar e controlar dados, utilizando a linguagem computacional SQL (Linguagem de Consulta Estruturada) como interface. Esse sistema está disponível gratuitamente e tem sido utilizado em diversos lugares no mundo, de acordo com as informações do site http://www.mysql.com/. Utilizamos o servidor HTTP Apache para executar os códigos do processador PHP em conjunto com o MySQL. O PHP: Hypertext Preprocessor é uma linguagem de programação disponível para desenvolvimento de aplicativos web, disponível gratuitamente em http://php.net/. Para aplicação dos dados nos sistemas operacionais citados, contamos com o serviço especializado de Paulo Ricardo Campos Viana, da área de desenvolvimento de bancos de dados e de software, que estruturou a parte técnica de informatização do dicionário.

Segue a estrutura do dicionário, como está concebida até o momento, e uma amostragem de verbetes.

\subsection{A informatização do banco de dados.}

A macroestrutura expõe recursos próprios para cadastro das informações que compõem o banco de dados, como apresentado na tela inicial da ferramenta: 


\section{Administirador}

Início | Verbetes | Páginas do Site | Sair

[ PÁGINAS ]

\begin{tabular}{|c|l|l|}
\hline Id & Nome da Página & Ação \\
\hline 1 & Apresentação da Obra \\
\hline 2 & Guia de Uso \\
\hline 3 & Lista de Abreviaturas \\
\hline 4 & Quadro Fonético Interativo \\
\hline 5 & Referências bibliográficas
\end{tabular}

Módulo de Administração do Site Dicionário - Desenvolvido por Paulo Viana

Figura 15: Página de cadastramento da macroestrutura no banco de dados (Fonte: MAIA-PIRES, 2015)

Ao acessar qualquer um dos recursos de 1 a 5 da Figura 15, uma caixa de texto é aberta para inserir as informações que são armazenadas por exportação de textos, vídeos, imagens, links ou digitadas no próprio programa, como apresentado na próxima figura. 
Início | Verbetes | Páginas do Site | Sair

\section{[ PAGINA ]}

\section{Editar Página}

Página: 1 - Apresentação da Obra

\begin{tabular}{|c|c|c|c|c|c|c|c|c|c|c|c|}
\hline File - & Edit & & & & lew & & Form & & Table . & Tool & \\
\hline क त & & rmats - & $\mathrm{E}$ & & $I$ & $\underline{u}$ & s & 豆 & 立 $\equiv$ & $\underline{\underline{\underline{\underline{ }}}}$ & 決、決、焉 \\
\hline$\infty$ & $\underline{I}_{x}$ & & & & & & & & & & \\
\hline $\bar{\theta}$ & 䀦 & A & A & & (-) & & & & & & \\
\hline
\end{tabular}

- Dicionário de aprendizagem de verbos do português do Brasil como L2 -Dicverb/PL2 é uma obra semibilíngue, português-inglês, especialmente elaborado para aprendizes do português do Brasil como segunda língua - L2. O dicionário é direcionado aos estrangeiros adultos, que possuem o inglês como primeira língua - L1 - ou como língua estrangeira LE, que se encontram em imersão no Brasil e estão em estágio inicial de aprendizagem da língua portuguesa.

- Dicverb/PL2 foi desenvolvido Centro de Estudos Lexicais e Terminológicos, Centro Lexterm, que, pela linha de pesquisa Léxico e Terminolgia do Programa de Pós-graduação da Universidade de Brasília - PPGL/UnB, oferece os meios para a elaboração de materiais lexicográficos e terminográficos.

o dicionário descreve 1000 verbos utilizados em uso real. Os significados dos verbos são descritos de acordo com 17 contextos do cotidiano dos brasileiros: alimentação, atividades comerciais, atividades domésticas, clima e tempo, crime e violência, educação, esporte, lazer, moradia, profissão e trabalho, relações sociais, trânsito e transporte, vestimentas e indumentárias e viagem e hospedagem. As definições estão acompanhadas de exemplos ilustrativos para demostrar o uso dos verbos em frases reais, retiradas de notícias publicadas em jornais, revistas e sites especializados no assunto e em falas de filmes brasileiros.

o dicionário de verbos fornece ao aorendiz informacões de ordem fonolóaica, morfolóaica, sintática, semântica e

Figura 16: Exemplo de recurso para cadastramento de dados (Fonte: MAIA-PIRES, 2015)

A microestrutura informatizada utiliza recursos próprios para cadastro das informações que aparecerão no verbete do dicionário, como apresentado na Figura 17. 


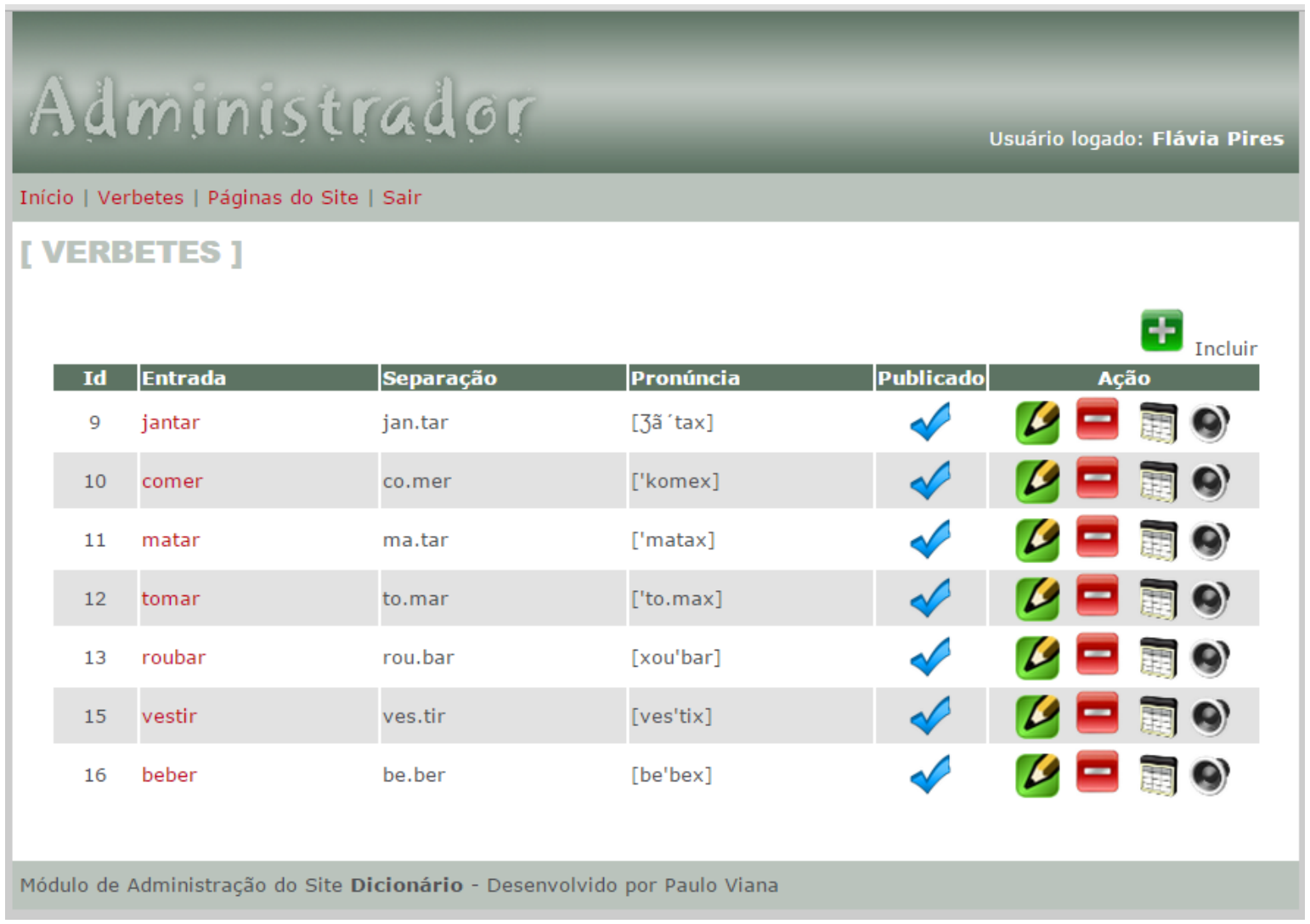

Figura 17: Página inicial de cadastramento do verbete

(fonte: MAIA-PIRES, 2015)

Uma vez delimitado o público-alvo do dicionário, optamos por apresentar um vocabulário básico que atenda à compreensão dos significados e conduza à produção de textos sobre o cotidiano dos brasileiros. Assim, o Dicverb/PL2 apresenta os significados dos verbos relacionados ao uso em 17 contextos do cotidiano dos brasileiros. Os contextos são informações extralinguísticas, referentes às condições de produção do significado em que o item lexical é usado: alimentação, atividades comerciais, atividades domésticas, clima e tempo, crime e violência, educação, esporte, lazer, moradia, profissão e trabalho, relações sociais, trânsito e transporte, vestimentas e indumentárias e viagem e hospedagem. Os contextos foram armazenados conforme a Figura 18: 


\section{Administirador}

\section{Inicio | Verbetes | Páginas do Site | Sair}

[ VERBETE]

Inclusão de Contexto

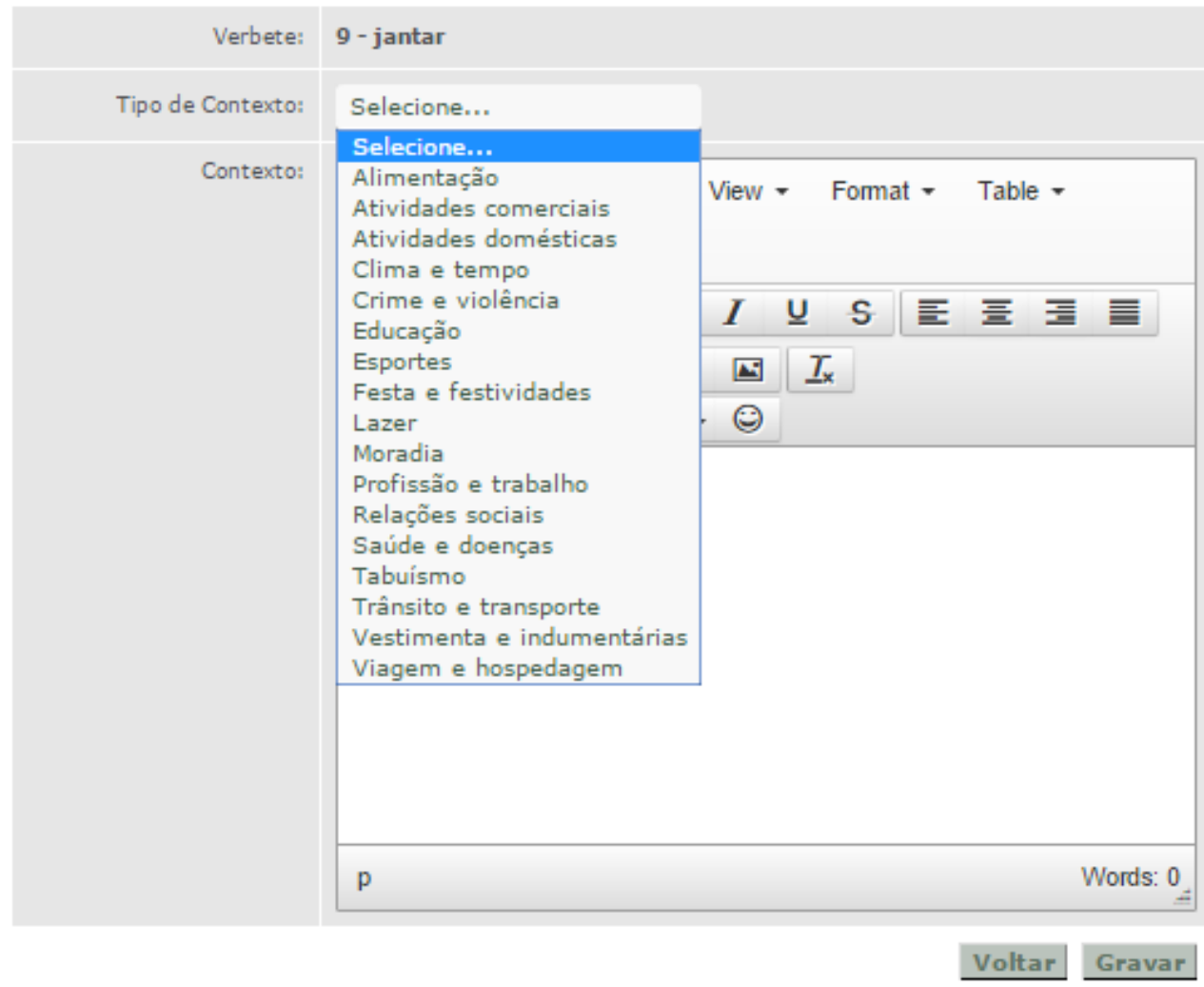

Módulo de Administração do Site Dicionário - Desenvolvido por Paulo Viana

Figura 18: Página de cadastramento dos contextos (fonte: MAIA-PIRES, 2015)

Informações como tipo de complemento verbal, exemplos de uso, modo informal, iten lexical correspondente e versão do exemplo de uso em inglês foram cadastradas, utilizando recursos próprios do programa, elaborados excluisivamente de acordo com uma função específica, conforme demonstra a Figura 19: 


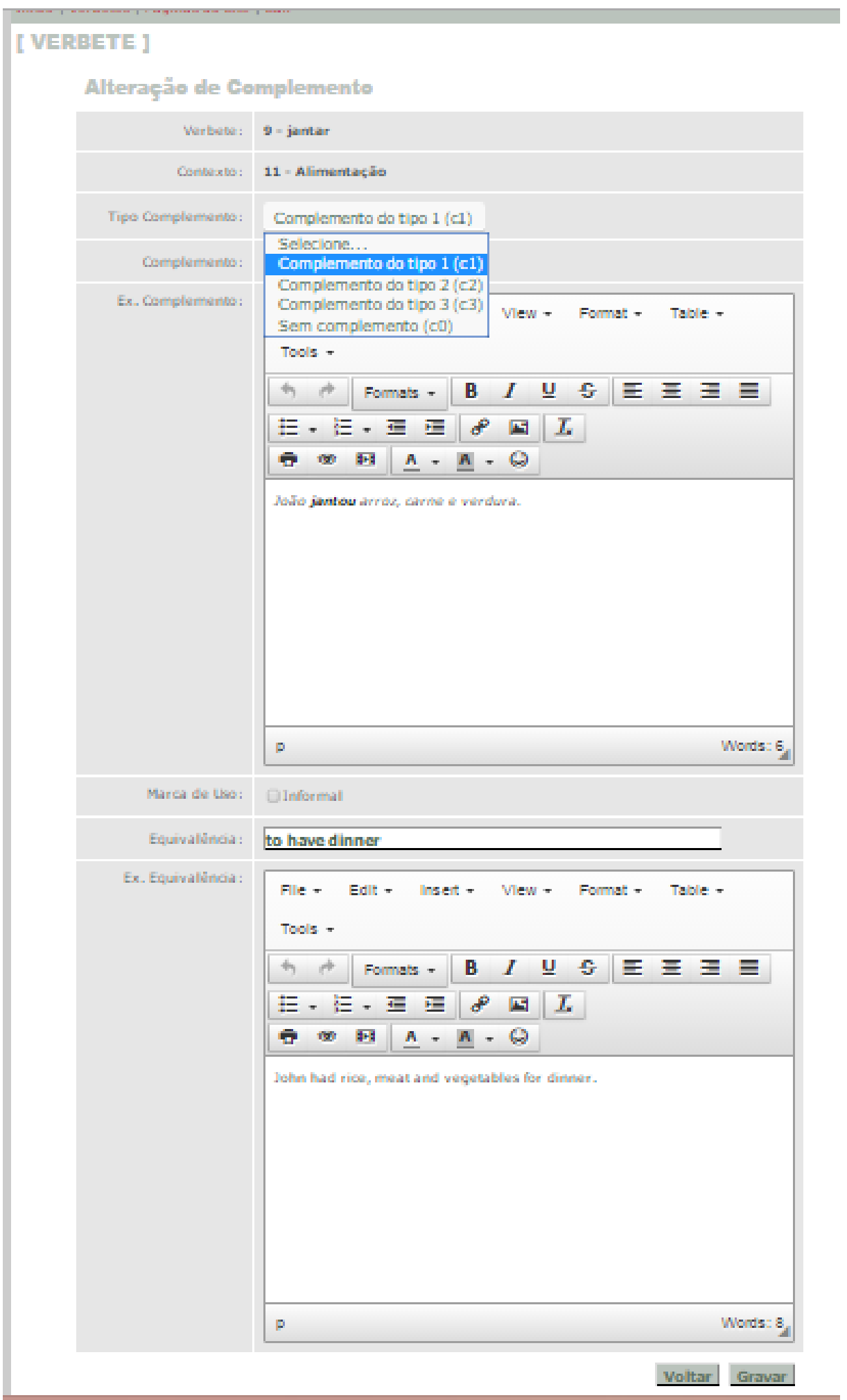

Figura 19: Página de cadastramento de equivalentes e exemplos de uso (fonte: MAIA-PIRES, 2015)

O programa para armazenamento de dados foi especialmente desenvolvido para organizar os dados de modo a compor o dicionário e permitir a manutenção das informações lexicográficas para atualizações, sempre que necessárias. 
Assim sendo, apresentamos o Dicionário de aprendizagem de verbos do português do Brasil como segunda língua - Dicverb/PL2, a seguir.

\subsection{A macroestrutura do Dicverb/PL2}

A macroestrutura é o conjunto das partes que compõem o dicionário como um todo e contém elementos norteadores que conduzem o usuário à compreensão linguística da obra lexicográfica. Para isso, a proposta do Dicionário de aprendizagem de verbos do português do Brasil como segunda língua - Dicverb/PL2, aqui sugerida, apresenta a macroestrutura organizada da seguinte forma:

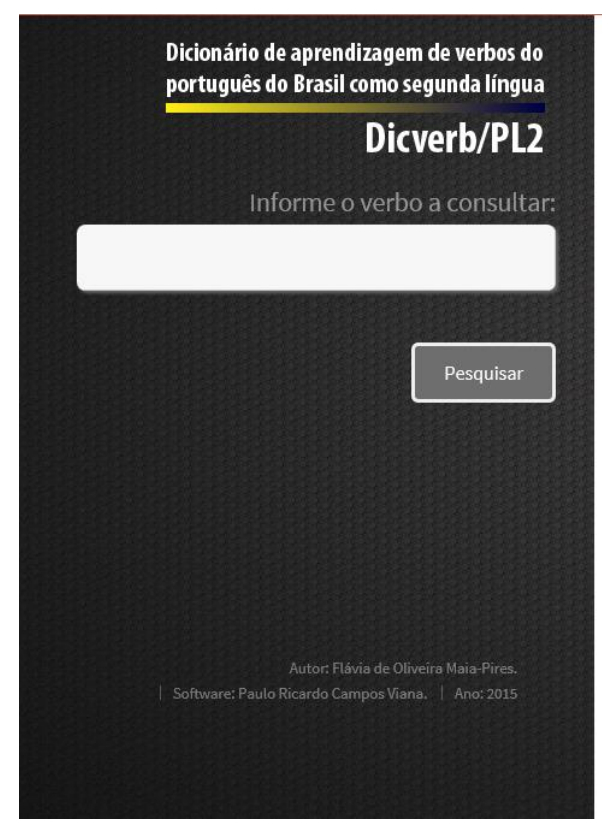

\section{Apresentação Guia de Uso Abreviaturas Quadro Fonético Ref. Bibliográficas}

\section{Apresentação da Obra}

o Dicionário de aprendizagem de verbos do português do Brasil como L2 -Dicverb/PL2 é uma obra semibilíngue, português-inglês, especialmente elaborado para aprendizes do português do Brasil como segunda língua - L2. 0 dicionário é direcionado aos estrangeiros adultos, que possuem o inglês como primeira língua - L1 - ou como língua estrangeira LE, que se encontram em imersão no Brasil e estão em estágio inicial de aprendizagem da língua portuguesa.

O Dicverb/PL2 foi desenvolvido no Centro de Estudos Lexicais e Terminológicos, Centro Lexterm, que, pela linha de pesquisa Léxico e Terminolgia do Programa de Pós-graduação da Universidade de Brasília - PPGL/UnB, oferece os meios para a elaboração de materiais lexicográficos e terminográficos.

O dicionário descreve 1000 verbos utilizados em uso real. Os significados dos verbos são descritos de acordo com 17 contextos do cotidiano dos brasileiros: alimentação, atividades comerciais, atividades domésticas, clima e tempo, crime e violência, educação, esporte, lazer, moradia, profissão e trabalho, relaçôes sociais, trânsito e transporte, vestimentas e indumentárias e viagem e hospedagem. As definições estão acompanhadas de exemplos ilustrativos para demostrar o uso dos verbos em frases reais, retiradas de notícias publicadas em jornais, revistas e sites especializados no assunto e em falas de filmes brasileiros.

O dicionário de verbos fornece ao aprendiz informações de ordem fonológica, morfológica, sintática, semântica e pragmática. $\mathrm{O}$ aspecto sintático-semântico classifica os verbos como verbo de estado, processo, ação e ação-processo. Os verbos de estado são aqueles que expressam uma propriedade (estado, condição, situação) localizada em um nome. Os verbos de processo são aqueles que expressam um evento ou sucessão de eventos que afetam um nome, provocando mudança de estado progressivamente. Os verbos de ação são aqueles que expressam uma ação, atividade, realizada por um nome. Os verbos de ação-processo são aqueles que expressam uma ação, atividade, realizada por um nome que afeta outro nome.

No guia de uso do Dicverb/PL2, o usuário encontra orientações para explorar as informações e as ferramentas do dicionário para auxiliá-lo na aprendizagem dos verbos da língua portuguesa, por isso é importante consultá-lo.

Autora: Flávia de Oliveira Maia-Pires. Software: Paulo Ricardo Campos Viana.

Figura 20: Página inicial do Dicverb/PL2

(Fonte: MAIA-PIRES, 2015)

O dicionário contém informações paralexicograficas, descritas a seguir: 


\section{a) Apresentação da obra}

A apresentação da obra está na página inicial do dicionário. Assim, o consulente conhecerá os objetivos e o público-alvo logo no primeiro contato com o Dicverb/PL2. Essa apresentação contempla os objetivos do dicionário, o público-alvo, o número de entradas, as fontes de onde o corpus foi extraído e a orientação para o usuário consultar o guia de uso. A apresentação está em português e em inglês, em vista de o público-alvo ser falante de língua inglesa como L1 e estar em estágio inicial de aprendizagem da língua portuguesa. Ao oferecer as duas opções de apresentação, em português e em inglês, o dicionário permite que o aprendiz obtenha informações para identificar o potencial da obra e da sua utilidade como material de aprendizagem.
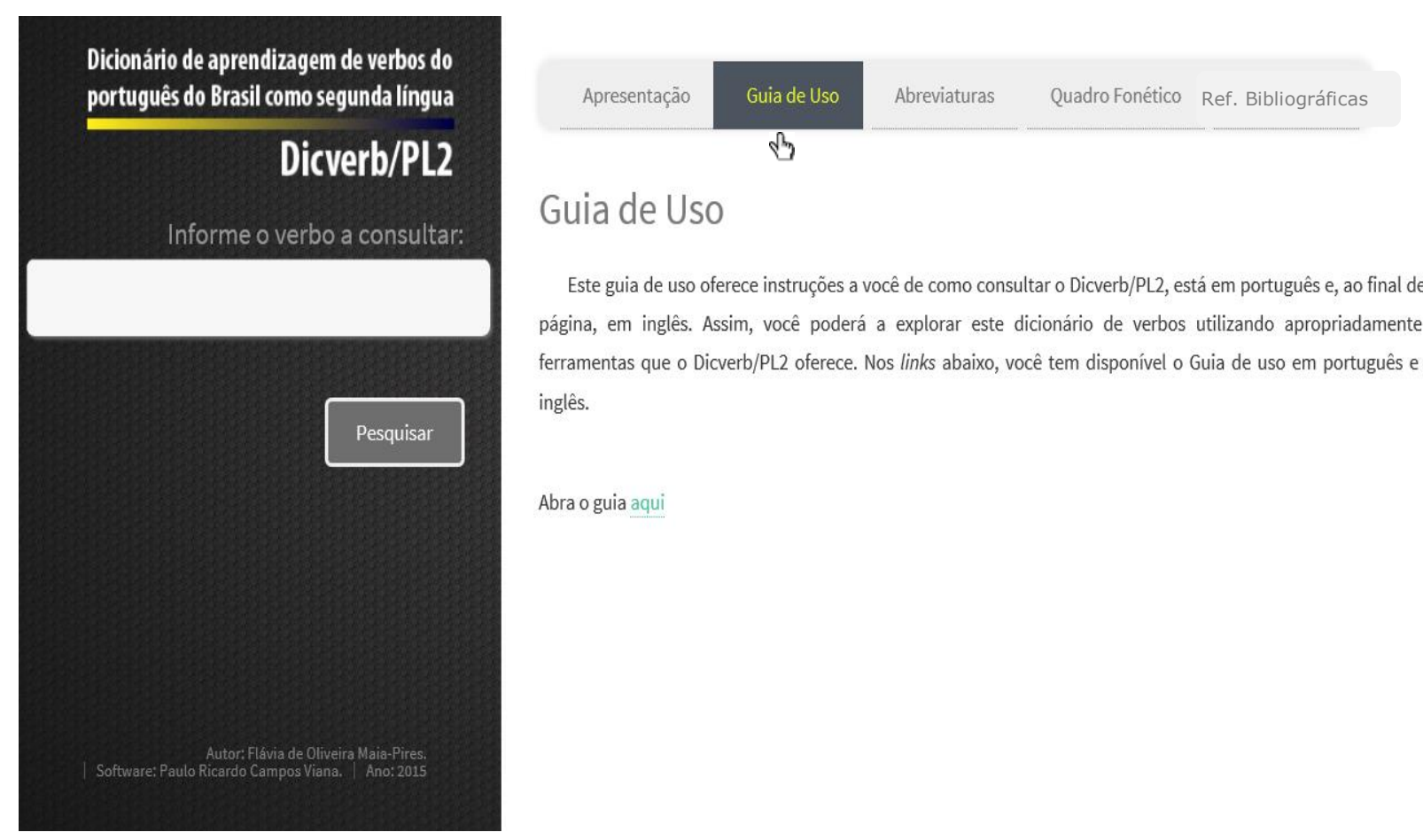

Este guia de uso oferece instruções a você de como consultar o Dicverb/PL2, está em português e, ao final desta página, em inglês. Assim, você poderá a explorar este dicionário de verbos utilizando apropriadamente as ferramentas que o Dicverb/PL2 oferece. Nos links abaixo, você tem disponível o Guia de uso em português e em inglês.

Abra o guia aqui

Figura 21: Página do guia de uso do Dicverb/PL2

(Fonte: MAIA-PIRES, 2015)

b) Guia de uso

O guia de uso instrui o usuário sobre como consultar o dicionário, está em português e em inglês. Entendemos que o usuário aprende a explorar o gênero lexicográfico, quando 
bem orientado na utilização da obra. Por isso, o guia de uso é útil nas explicações das ferramentas disponíveis e na explicação de como cada elemento da composição funciona.

\section{c) Lista de abreviaturas e símbolos}
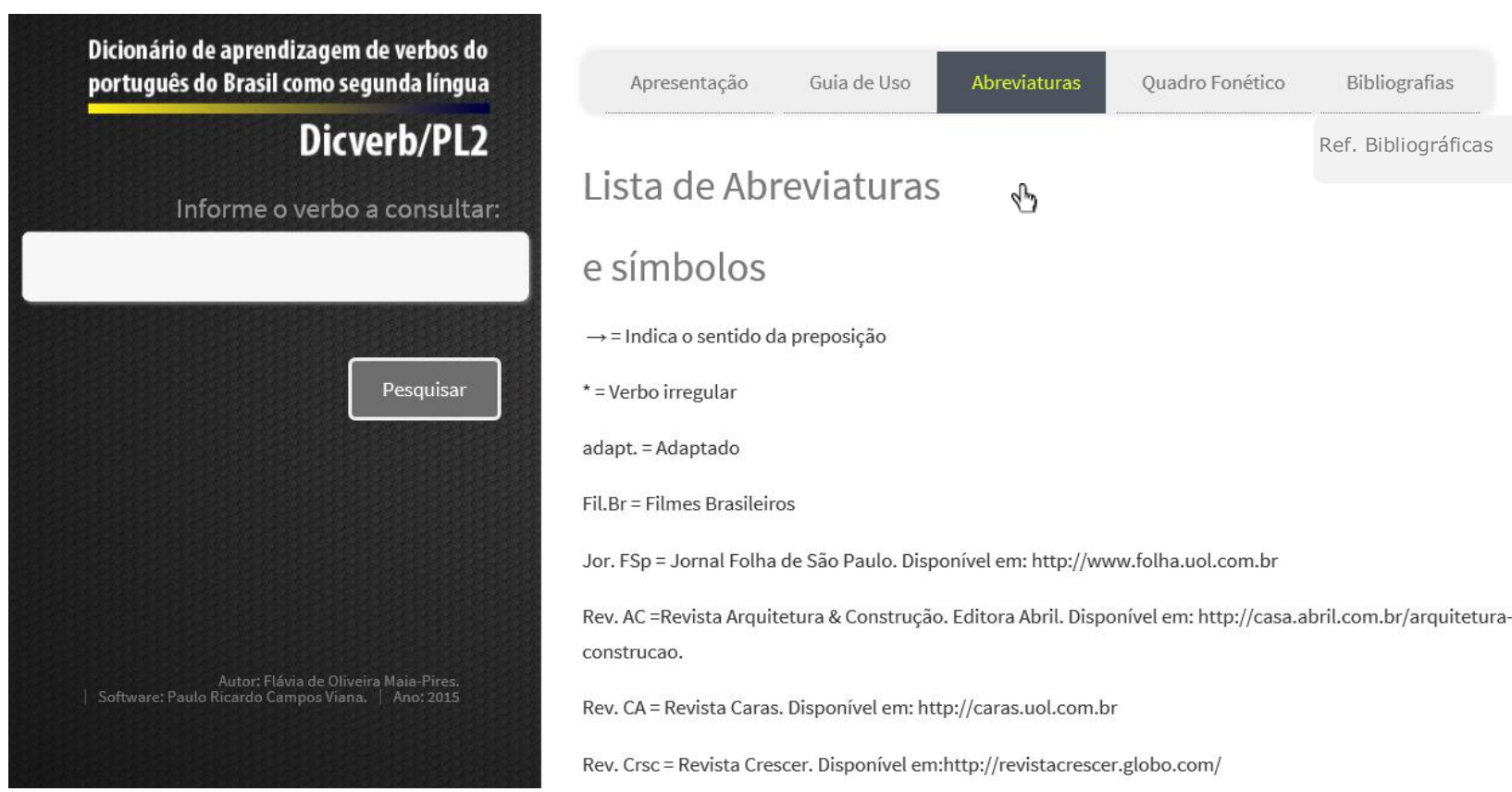

Rev. EV = Revista Estilo de vida. Editora Abril. Disponível em: http://mdemulher.abril.com.br/revistas/estilo Rev. Ex = Revista Exame. Editora Abril. Disponível em: http://exame.abril.com.br/ Rev. Fam = Revista Família. Disponível em http://mdemulher.abril.com.br/familia Rev. GR = Revista Globo Rural. Editora Globo. http://revistagloborural.globo.com/ Rev. NE = Revista Nova Escola. Editora Abril. Disponível em: http://revistaescola.abril.com.br Rev. SUd = Revista Saúde. Editora Abril. Disponível em: http://mdemulher.abril.com.br/revistas/saude Rev. Vig = Revista Viagem. Editora Abril. Disponível em: http://viajeaqui.abril.com.br/vt Rev. VS =Revista Vida simples. Editora Abril. Disponível em: http://vidasimples.abril.com.br Rev.CB = Revista Veja Comer \& Beber. Editora Abril. Disponível em: http://vejabrasil.abril.com.br/portal S.Esp = Esportes: Site do Globo Esporte. Disponível em:http://globoesporte.globo.com S.Esp.PI = Site de Esporte Placar Abril. Disponível em:http://placar.abril.com.br/ S. Gbook = Site de livros. 150 ideias para trabalho com crianças. Disponível em:https://books.google.com.br S.Gaz.GI = Site do Jornal Gazeta. Disponível em:http://gazetaonline.globo.com/ S.G1 = Site do Jornal Globo. Disponível em:http://g1.globo.com/index.html Gshow.Gl = Site Globo. Disponível em: http://gshow.globo.com/

Figura 22: Página de Abreviaturas do Dicverb/PL2 (Fonte: MAIA-PIRES, 2015)

A lista de abreviaturas indica as formas reduzidas da nomenclatura utilizada no dicionário, familiarizando o usuário com o corpus utilizado na obra. O link Abreviaturas do 
Dicverb/PL2 está sempre visível ao usuário, na parte superior, para que ele obtenha as informações das formas reduzidas utilizadas no dicionário.
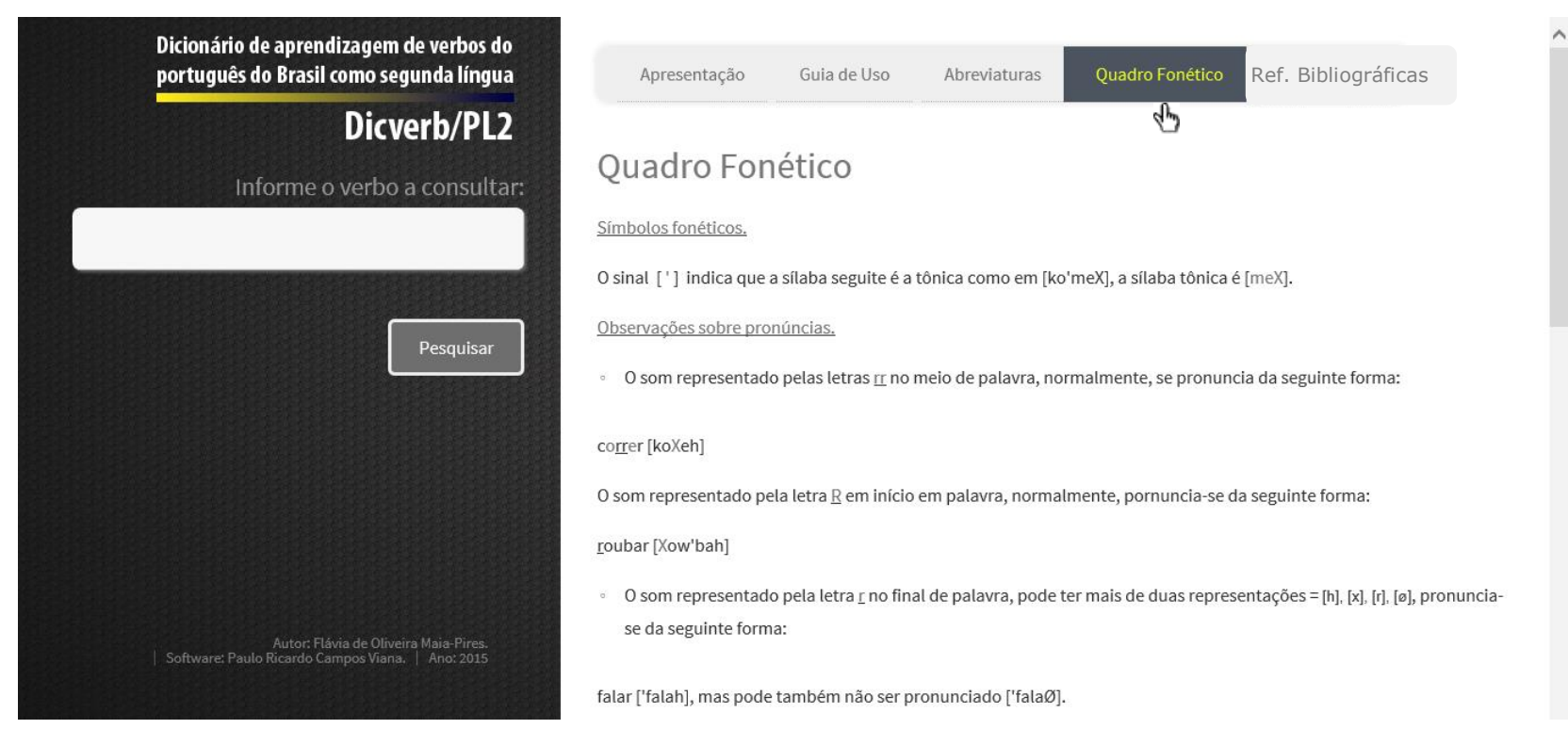

0 som representado pela letra $t$ antes da vogal i, normalmente, pronuncia-se da seguinte forma:

țirar ['t firah], mas pode também ser pronunciado ['tirah]

- 0 quadro abaixo apresenta, na cor verde,as consoantes do português

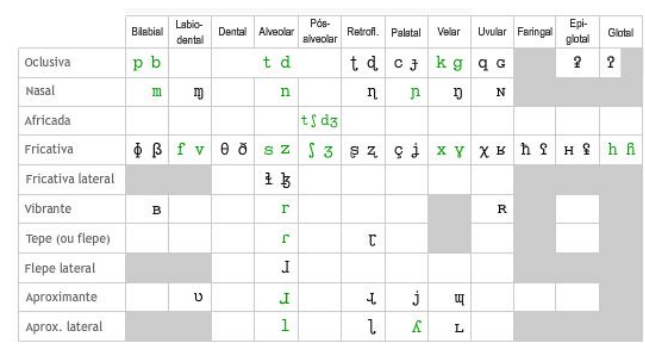

O som representado pela letra e pode ser pronunciado com som de [i], como:

O som representado pela letra o pode ser pronunciado como o som de [w] como:

- O quadro abaixo apresenta, na cor verde, as vogais do português.

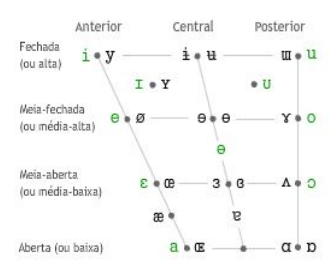

Você poderá ouvir os sons isoladamente acessando os links abaixo.

Para o som das consoantes http://www.fonologia.org/fonetica_consoantes.php

Para o som das vogais http://www.fonologia.org/fonetica_vogais.php

Figura 23: Página do Quadro Fonético do Dicverb/PL2 (Fonte: MAIA-PIRES, 2015) 


\section{d) Quadro fonético}

O quadro fonético indica que o sistema fonético da língua portuguesa foi idealizado para oferecer ao usuário o sistema dos sons da língua portuguesa. O quadro utiliza o International Phonetic Alphabet - IPA. Além do quadro fonético, há breve descrição sobre a fonética e a fonologia da língua portuguesa.

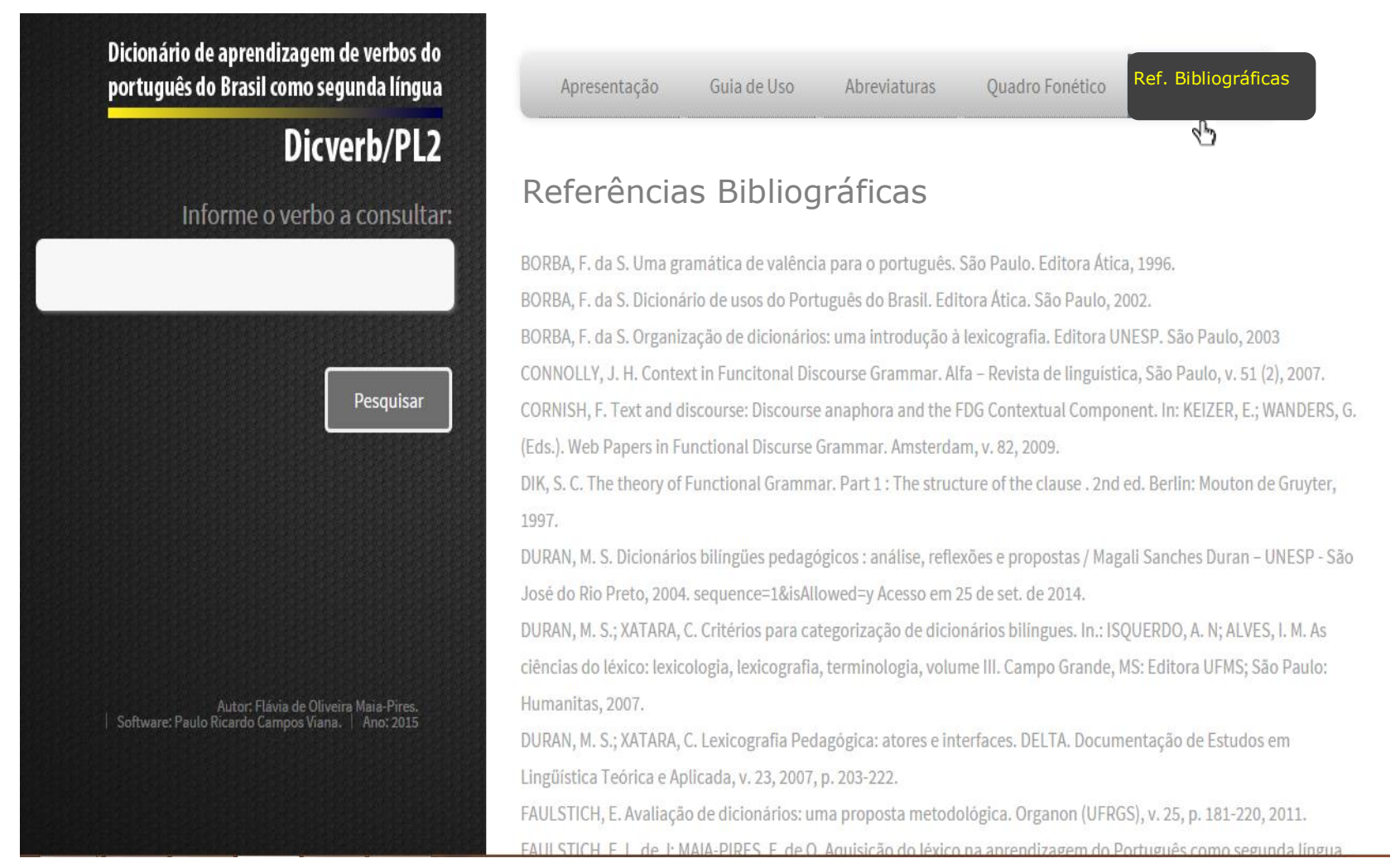

Figura 24: Página de referências bibliográficas do Dicverb/PL2 (Fonte: MAIA-PIRES, 2015)

\section{e) Referências Bibliográficas}

Apresenta as referências bibliográficas e as fontes dos exemplos de uso utilizados na elaboração do Dicverb/PL2. 


\section{f) Recurso de busca}

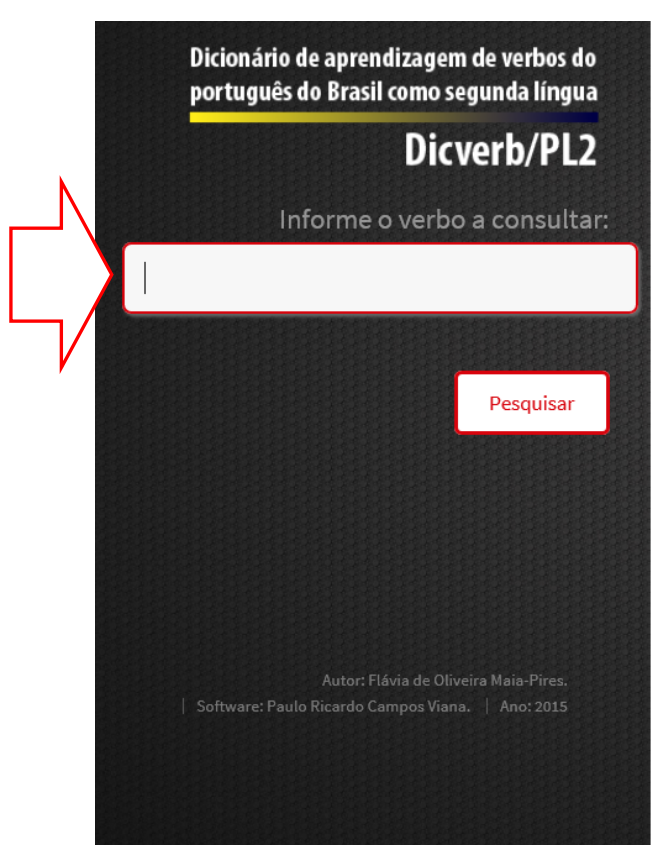

Apresentação Guia de Uso Abreviaturas Quadro Fonético Ref. Bibliográficas

\section{Apresentação da Obra}

o Dicionário de aprendizagem de verbos do português do Brasil como L2 -Dicverb/PL2 é uma obra semibilíngue, português-inglês, especialmente elaborado para aprendizes do português do Brasil como segunda língua - L2. O dicionário é direcionado aos estrangeiros adultos, que possuem o inglês como primeira língua - L1 - ou como língua estrangeira LE, que se encontram em imersão no Brasil e estão em estágio inicial de aprendizagem da língua portuguesa.

O dicionário descreve 1000 verbos utilizados em uso real. Os significados dos verbos são descritos de acordo com 17 contextos do cotidiano dos brasileiros: alimentação, atividades comerciais, atividades domésticas, clima e tempo, crime e violência, educação, esporte, lazer, moradia, profissão e trabalho, relações sociais, trânsito e transporte, vestimentas e indumentárias e viagem e hospedagem. As definições estão acompanhadas de exemplos ilustrativos para demostrar o uso dos verbos em frases reais, retiradas de notícias publicadas em jornais, revistas e sites especializados no assunto e em falas de filmes brasileiros.

O dicionário de verbos fornece ao aprendiz informações de ordem fonológica, morfológica, sintática, semântica e pragmática. $\mathrm{O}$ aspecto sintático-semântico classifica os verbos como verbo de estado, processo, ação e açãoprocesso. Os verbos de estado são aqueles que expressam uma propriedade (estado, condição, situação) localizada em um nome. Os verbos de processo são aqueles que expressam um evento ou sucessão de eventos que afetam um nome, provocando mudança de estado progressivamente. Os verbos de ação são aqueles que expressam uma ação, -1...

Figura 25: Página inicial com recurso de busca do Dicverb/PL2

(Fonte: MAIA-PIRES, 2015)

O recurso de busca de palavras sugere ou indica a forma correta da grafia de palavras e oferece a oportunidade de o usuário aprender a escrever. Caso o usuário não tenha digitado corretamente, aparecerá uma lista de palavras com ortografia próxima à digitada.

\subsection{A microestrutura do Dicverb/PL2}

A microestrutura é a unidade mínima autônoma; é também “chamada de verbete ou de artigo lexicográfico" (FAULSTICH, 2011, p. 183). Essa unidade, no Dicverb/PL2, descreve a entrada, a ortografia, a transcrição da pronúncia, a divisão silábica, a(s) acepção(ões), o complemento verbal, o exemplo de uso, a marca de uso, a preposição exigida pela regência verbal, a equivalência em inglês, a versão do exemplo de uso em inglês, o quadro de conjugação verbal e o recurso auditivo da pronúncia do verbo. 

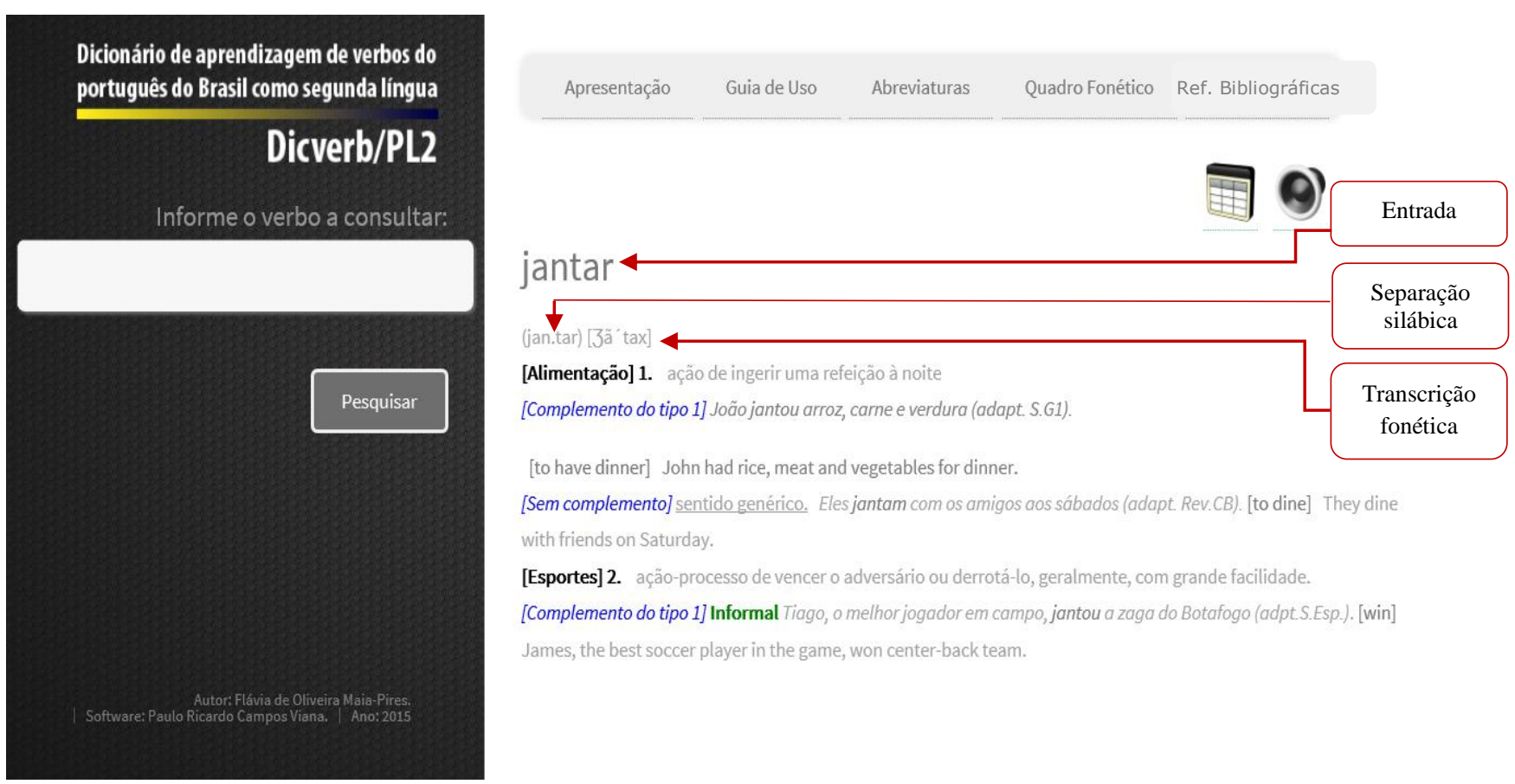

[to have dinner] John had rice, meat and vegetables for dinner.

[Sem complemento] sentido genérico. Eles jantam com os amigos aos sábados (adapt. Rev.CB). [to dine] They dine with friends on Saturday.

[Esportes] 2. ação-processo de vencer o adversário ou derrotá-lo, geralmente, com grande facilidade.

[Complemento do tipo 1] Informal Tiago, o melhor jogador em campo, jantou a zaga do Botafogo (adpt.S. Esp.). [win]

James, the best soccer player in the game, won center-back team.

Figura 26: Exemplo de verbete

a) Entrada, "indicativo da unidade linguística que possui conteúdo semântico e descreve o padrão ortográfico da língua” (FAULTISCH, 2011). Será registrada em letras minúsculas, em negrito, em fonte maior que as outras palavras do verbete e na forma de lema, que é a forma não flexionada do verbo.

b) Divisão silábica, indicativo da constituição da sílaba da palavra na língua portuguesa, apresentada entre parênteses e separados por ponto ( . ). Esse recurso fornece informações sobre as combinações dos grupos de fonemas possíveis na língua portuguesa e como são representados no sistema gráfico; auxilia o aprendiz na percepção da posição do acento tônico e das regras de acentuação das palavras.

c) Transcrição fonética do item lexical, indica o conjunto de sons e das combinações possíveis no português, o que permitirá a compreensão e a produção da fala; isso facilitará a aprendizagem da fonética e da fonologia; é descrita entre colchetes [ ].

A transcrição baseia-se no sistema de notação fonética do Alfabeto Fonético Internacional, AFI (sigla em português), International Phonetic Alphabet, IPA (sigla em inglês) e nas informações fonéticas de Cristófaro-Silva (2009), disponíveis no site http://www.fonologia.org, consultado em fevereiro de 2015. 
Por ser o Brasil um país de diversidade prosódica, optamos por registrar a pronúncia usada na capital do país, que foi inserida na microestrutura por programa computacional apropriado. A pronúncia registrada é de um(a) brasiliense, cujos pais também são nascidos em Brasília, na área tombada como Patrimônio Mundial da UNESCO, maior de 18 anos, com Ensino Médio completo e residente no Plano Piloto de Brasília ${ }^{24}$.

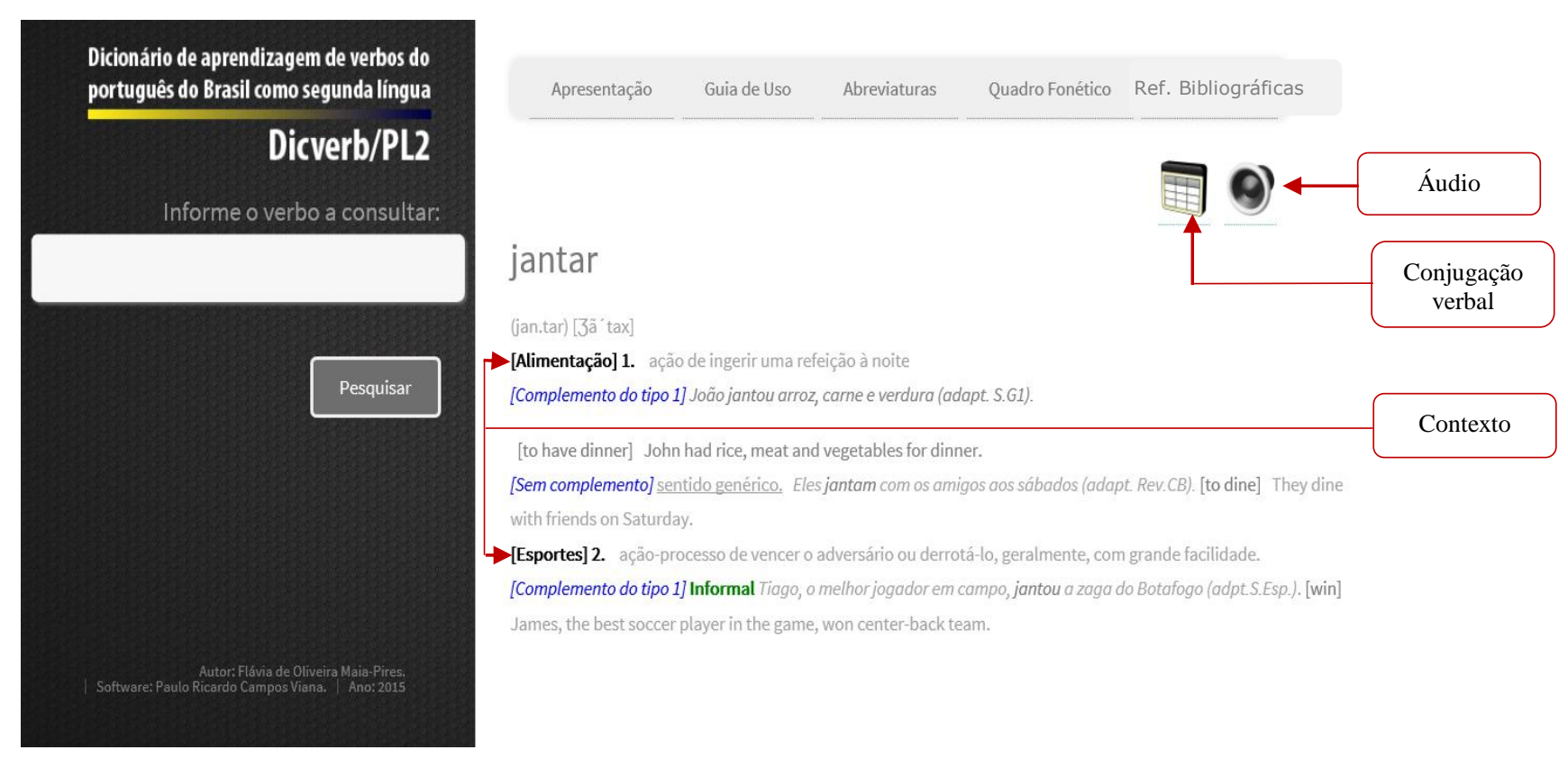

Figura 27: Página do verbete jantar do Dicverb/PL2 (Fonte: MAIA-PIRES, 2015)

d) Áudio, recurso que reproduz a pronúncia do verbo para fornecer ao aprendiz um exemplo do falar de um brasileiro.

e) Conjugação verbal, indicativo do processo morfológico dos verbos mediante conjugação que expressa tempo, modo, número e pessoa do discurso. Por ser um dicionário pedagógico, são utilizados, sistematicamente, recursos gráficos diferenciados para indicar informações distintas, como cores, destaques em itálico, em negrito, em letras maiúsculas, com funções específicas. A conjugação verbal foi organizada de forma a evidenciar as pessoas do discurso $e u, t u$, ele, nós, vós, eles e a demonstrar a variação linguística do português do Brasil, incluídos, por isso, você, a gente e vocês. A inclusão de você, como segunda pessoa do singular ( $2^{\mathrm{a}} \mathrm{p}$. sg. $)$, a gente como primeira pessoa do plural

\footnotetext{
${ }^{24}$ Os limites concernetes à área tombada de Brasília respaldam-se em nosso estudo da terminologia da estrutura urbana do Plano Piloto de Brasília realizado em nossa dissertação de mestrado em 2009 - Brasília em termos: um estudo lexical do Plano Piloto.
} 
( $1^{\mathrm{a}}$ p. pl.) e vocês como segunda pessoa do plural ( $2^{\mathrm{a}}$ p. pl.), serve para demonstrar a variação brasileira comprovada pelo uso, como descrevem Bechara (2009, p. 166) e Castilho (2010, p. 477), em que você ( $2^{\mathrm{a}}$ p. pl.) e a gente ( $1^{\mathrm{a}}$ p. pl.) conjugam-se com a forma do verbo na terceira pessoa do singular e vocês $\left(2^{\mathrm{a}} \mathrm{p}\right.$. pl.) conjuga-se com a forma do verbo na terceira pessoa do plural. A vogal temática dos verbos que os distinguem em $1^{\mathrm{a}}, 2^{\mathrm{a}}$ e $3^{\mathrm{a}}$ conjugação estão em itálico, como jantar, comer, abrir. O sufixo que indica modo e tempo está na cor vermelha e em negrito, como jantava, jantara, jantasse. A desinência que indica númeropessoa está em vermelho, sem negrito, como jantavas, jantaste, jantávamos, jantamos. Foram mantidos na conjugação os modos e as pessoas do discurso que têm baixa frequência de uso ou estão em desuso, como o pretérito mais-que-perfeito e, em todos os tempos e modos, a $2^{\mathrm{a}}$ pessoa do plural, vós. Nesse recurso do Dicverb/PL2, foi disponibilizada a opção de imprimir a grade com as conjugações, ao clicar com o botão direito na tela de conjugação. 


\begin{tabular}{|c|c|c|c|c|c|c|c|c|c|}
\hline \multirow[b]{3}{*}{ Tempo } & \multicolumn{9}{|c|}{ Modo: Indicativo } \\
\hline & \multicolumn{3}{|c|}{ Singular } & \multicolumn{3}{|c|}{ Plural } & \multicolumn{3}{|c|}{ Informal } \\
\hline & $1^{\mathrm{a}}$ & $2^{\mathrm{a}}$ & $3^{a}$ & $1^{2}$ & $2^{\mathrm{a}}$ & $3^{\mathrm{a}}$ & $\begin{array}{c}2^{\mathbf{a}} \\
\text { Singular }\end{array}$ & $\begin{array}{c}1^{\mathrm{a}} \\
\text { Plural }\end{array}$ & $\begin{array}{c}2^{\mathrm{a}} \\
\text { Plural }\end{array}$ \\
\hline Presente & $\begin{array}{l}E u \\
\text { janto }\end{array}$ & $\begin{array}{l}\text { Tu } \\
\text { jantas }\end{array}$ & $\begin{array}{l}\text { Ele } \\
\text { janta }\end{array}$ & $\begin{array}{l}\text { Nós } \\
\text { jantamos }\end{array}$ & $\begin{array}{l}\text { Vós } \\
\text { jantais }\end{array}$ & $\begin{array}{l}\text { Eles } \\
\text { jantam }\end{array}$ & $\begin{array}{l}\text { Você } \\
\text { janta }\end{array}$ & $\begin{array}{l}\text { A gente } \\
\text { janta }\end{array}$ & $\begin{array}{l}\text { Vocês } \\
\text { jantam }\end{array}$ \\
\hline $\begin{array}{l}\text { Pretérito } \\
\text { Imperfeito }\end{array}$ & $\begin{array}{l}\text { Eu } \\
\text { jantava }\end{array}$ & $\begin{array}{l}\text { Tu } \\
\text { jantavas }\end{array}$ & $\begin{array}{l}\text { Ele } \\
\text { jantava }\end{array}$ & $\begin{array}{l}\text { Nós } \\
\text { jantávamos }\end{array}$ & $\begin{array}{l}\text { Vós } \\
\text { jantáveis }\end{array}$ & $\begin{array}{l}\text { Eles } \\
\text { jantavam }\end{array}$ & $\begin{array}{l}\text { Você } \\
\text { jantava }\end{array}$ & $\begin{array}{l}\text { A gente } \\
\text { jantava }\end{array}$ & $\begin{array}{l}\text { Vocês } \\
\text { jantavam }\end{array}$ \\
\hline $\begin{array}{l}\text { Pretérito } \\
\text { Perfeito }\end{array}$ & $\begin{array}{l}\text { Eu } \\
\text { jantei }\end{array}$ & $\begin{array}{l}\text { Tu } \\
\text { jantaste }\end{array}$ & $\begin{array}{l}\text { Ele } \\
\text { jantou }\end{array}$ & $\begin{array}{l}\text { Nós } \\
\text { jantamos }\end{array}$ & $\begin{array}{l}\text { Vós } \\
\text { jantastes }\end{array}$ & $\begin{array}{l}\text { Eles } \\
\text { jantaram }\end{array}$ & $\begin{array}{l}\text { Você } \\
\text { jantou }\end{array}$ & $\begin{array}{l}\text { A gente } \\
\text { jantou }\end{array}$ & $\begin{array}{l}\text { Vocês } \\
\text { jantaram }\end{array}$ \\
\hline $\begin{array}{l}\text { Pretérito } \\
\text { mais que } \\
\text { Perfeito }\end{array}$ & $\begin{array}{l}\text { Eu } \\
\text { jantara }\end{array}$ & $\begin{array}{l}\text { Tu } \\
\text { jantaras }\end{array}$ & $\begin{array}{l}\text { Ele } \\
\text { jantara }\end{array}$ & $\begin{array}{l}\text { Nós } \\
\text { jantáramos }\end{array}$ & $\begin{array}{l}\text { Vós } \\
\text { jantareis }\end{array}$ & $\begin{array}{l}\text { Eles } \\
\text { jantaram }\end{array}$ & $\begin{array}{l}\text { Você } \\
\text { jantara }\end{array}$ & $\begin{array}{l}\text { A gente } \\
\text { jantara }\end{array}$ & $\begin{array}{l}\text { Vocês } \\
\text { jantaram }\end{array}$ \\
\hline $\begin{array}{l}\text { Futuro do } \\
\text { Pretérito }\end{array}$ & $\begin{array}{l}\text { Eu } \\
\text { jantaria }\end{array}$ & $\begin{array}{l}\text { Tu } \\
\text { jantarias }\end{array}$ & $\begin{array}{l}\text { Ele } \\
\text { jantaria }\end{array}$ & $\begin{array}{l}\text { Nós } \\
\text { jantaríamos }\end{array}$ & $\begin{array}{l}\text { Vós } \\
\text { jantaríeis }\end{array}$ & $\begin{array}{l}\text { Eles } \\
\text { jantariam }\end{array}$ & $\begin{array}{l}\text { Você } \\
\text { jantaria }\end{array}$ & $\begin{array}{l}\text { A gente } \\
\text { jantaria }\end{array}$ & $\begin{array}{l}\text { Vocês } \\
\text { jantariam }\end{array}$ \\
\hline $\begin{array}{l}\text { Futuro do } \\
\text { Presente }\end{array}$ & $\begin{array}{l}\text { Eu } \\
\text { jantarei }\end{array}$ & $\begin{array}{l}\text { Tu } \\
\text { jantarás }\end{array}$ & $\begin{array}{l}\text { Ele } \\
\text { jantará }\end{array}$ & $\begin{array}{l}\text { Nós } \\
\text { jantaremos }\end{array}$ & $\begin{array}{l}\text { Vós } \\
\text { jantareis }\end{array}$ & $\begin{array}{l}\text { Eles } \\
\text { jantarão }\end{array}$ & $\begin{array}{l}\text { Você } \\
\text { jantará }\end{array}$ & $\begin{array}{l}\text { A gente } \\
\text { jantará }\end{array}$ & $\begin{array}{l}\text { Vocês } \\
\text { jantarão }\end{array}$ \\
\hline
\end{tabular}




\begin{tabular}{|c|c|c|c|c|c|c|c|c|c|}
\hline \multirow[b]{3}{*}{ Tempo } & \multicolumn{9}{|c|}{ Modo: Subjuntivo } \\
\hline & \multicolumn{3}{|c|}{ Singular } & \multicolumn{3}{|c|}{ Plural } & \multicolumn{3}{|c|}{ Informal } \\
\hline & $1^{a}$ & $2^{\mathrm{a}}$ & $3^{a}$ & $1^{a}$ & $2^{a}$ & $3^{a}$ & $\begin{array}{c}\mathbf{2}^{\mathbf{a}} \\
\text { Singular }\end{array}$ & $\begin{array}{c}1^{a} \\
\text { Plural }\end{array}$ & $\begin{array}{c}2^{\mathbf{a}} \\
\text { Plural }\end{array}$ \\
\hline Presente & $\begin{array}{l}\text { Eu } \\
\text { jante }\end{array}$ & $\begin{array}{l}\text { Tu } \\
\text { jantes }\end{array}$ & $\begin{array}{l}\text { Ele } \\
\text { jante }\end{array}$ & $\begin{array}{l}\text { Nós } \\
\text { jantemos }\end{array}$ & $\begin{array}{l}\text { Vós } \\
\text { janteis }\end{array}$ & $\begin{array}{l}\text { Ele } \\
\text { jantem }\end{array}$ & $\begin{array}{l}\text { Você } \\
\text { jante }\end{array}$ & $\begin{array}{l}\text { A gente } \\
\text { jante }\end{array}$ & $\begin{array}{l}\text { Vocês } \\
\text { jantem }\end{array}$ \\
\hline Pretérito & $\begin{array}{l}\text { Eu } \\
\text { jantasse }\end{array}$ & $\begin{array}{l}\text { Tu } \\
\text { jantasses }\end{array}$ & $\begin{array}{l}\text { Ele } \\
\text { jantasse }\end{array}$ & $\begin{array}{l}\text { Nós } \\
\text { jantássemos }\end{array}$ & $\begin{array}{l}\text { Vós } \\
\text { jantásseis }\end{array}$ & $\begin{array}{l}\text { Eles } \\
\text { jantassem }\end{array}$ & $\begin{array}{l}\text { Você } \\
\text { jantasse }\end{array}$ & $\begin{array}{l}\text { A gente } \\
\text { jantasse }\end{array}$ & $\begin{array}{l}\text { Você } \\
\text { jantassem }\end{array}$ \\
\hline Futuro & $\begin{array}{l}\text { Eu } \\
\text { jantar }\end{array}$ & $\begin{array}{l}\text { Tu } \\
\text { jantares }\end{array}$ & $\begin{array}{l}\text { Ele } \\
\text { jantar }\end{array}$ & $\begin{array}{l}\text { Nós } \\
\text { jantarmos }\end{array}$ & $\begin{array}{l}\text { Vós } \\
\text { jantardes }\end{array}$ & $\begin{array}{l}\text { Eles } \\
\text { jantarem }\end{array}$ & $\begin{array}{l}\text { Você } \\
\text { jantar }\end{array}$ & $\begin{array}{l}\text { A gente } \\
\text { jantar }\end{array}$ & $\begin{array}{l}\text { Vocês } \\
\text { jantarem }\end{array}$ \\
\hline
\end{tabular}

\begin{tabular}{|c|c|c|c|c|c|c|c|c|c|}
\hline & \multicolumn{9}{|c|}{ Modo: Imperativo } \\
\hline & \multicolumn{3}{|c|}{ Singular } & \multicolumn{3}{|c|}{ Plural } & \multicolumn{3}{|c|}{ Informal } \\
\hline & $1^{a}$ & $2^{a}$ & $3^{a}$ & $1^{a}$ & $2^{a}$ & $3^{a}$ & $\begin{array}{c}\mathbf{2}^{\mathbf{a}} \\
\text { Singular }\end{array}$ & $\begin{array}{c}1^{\mathbf{a}} \\
\text { Plural }\end{array}$ & $\begin{array}{c}2^{\mathrm{a}} \\
\text { Plural }\end{array}$ \\
\hline Afirmativo & ---- & $\begin{array}{l}\text { Tu } \\
\text { janta }\end{array}$ & $\begin{array}{l}\text { Ele } \\
\text { jante }\end{array}$ & $\begin{array}{l}\text { Nós } \\
\text { jantemos }\end{array}$ & $\begin{array}{l}\text { Vós } \\
\text { jantais }\end{array}$ & $\begin{array}{l}\text { Ele } \\
\text { jantem }\end{array}$ & $\begin{array}{l}\text { Você } \\
\text { jante }\end{array}$ & $\begin{array}{l}\text { A gente } \\
\text { jante }\end{array}$ & $\begin{array}{l}\text { Vocês } \\
\text { jantem }\end{array}$ \\
\hline Negativo & 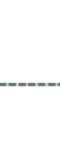 & $\begin{array}{l}\text { Tu não } \\
\text { jantes }\end{array}$ & $\begin{array}{l}\text { Ele não } \\
\text { jante }\end{array}$ & $\begin{array}{l}\text { Nós não } \\
\text { jentemos }\end{array}$ & $\begin{array}{l}\text { Vós não } \\
\text { janteis }\end{array}$ & $\begin{array}{l}\text { Eles não } \\
\text { jantem }\end{array}$ & $\begin{array}{l}\text { Você não } \\
\text { jante }\end{array}$ & $\begin{array}{l}\text { A gente } \\
\text { não } \\
\text { jante }\end{array}$ & $\begin{array}{l}\text { Vocês } \\
\text { não } \\
\text { jantem }\end{array}$ \\
\hline
\end{tabular}

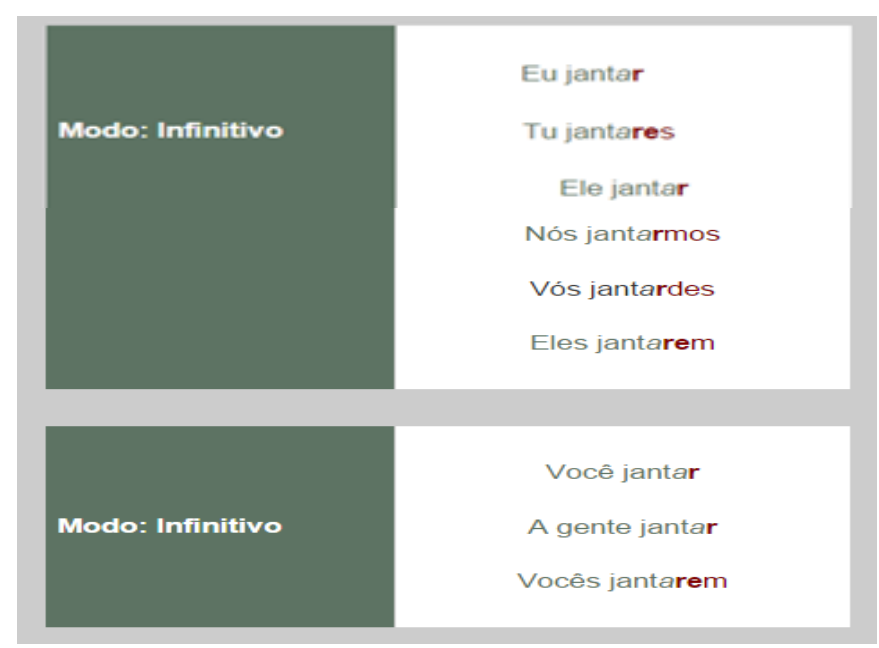




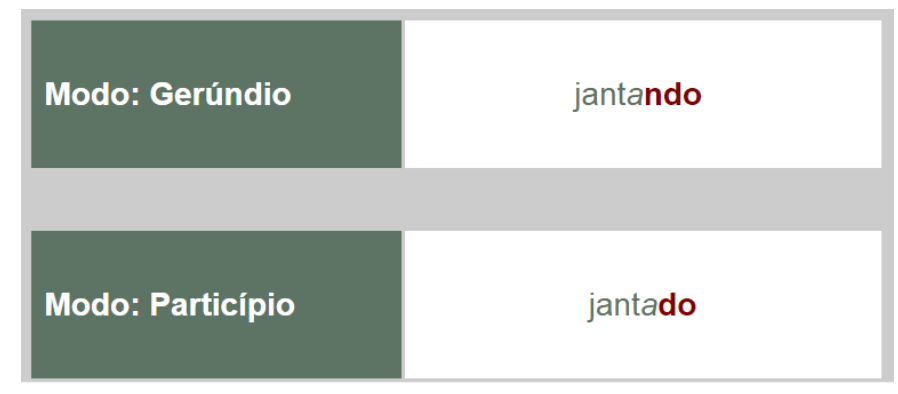

Figura 28: Página de conjugação verbal

f) Contexto, indicativo de informações extralinguísticas referentes às condições de produção do significado em que o item lexical é usado; fornece informações como tempo, espaço, participantes do evento comunicativo, organização social, normas de pensamento e comportamento da comunidade de fala. Assim, essas informações delimitam o significado dos verbos; estão em negrito, entre colchetes [ ] e se iniciam com letra maiúscula. Uma vez delimitado o público-alvo do dicionário, o Dicverb/PL2 apresenta um vocabulário básico para atender à compreensão e à produção de textos sobre o cotidiano dos brasileiros, em torno dos seguintes contextos:

\section{1) [Alimentar]}

Contextos relacionados à ação, ao estado ou ao processo de alimentar ou nutrir o corpo com substâncias digeríveis pelo organismo.

\section{2) [Atividades comerciais]}

Contextos relacionados à ação, ao estado ou ao processo de atividades de troca, de venda ou de compra de bens, produtos, mercadorias e serviços.

\section{3) [Atividades domésticas]}

Contextos relacionados à ação, ao estado ou ao processo que envolvem as atividades, a administração ou a organização do lar, da família, da vida particular de uma pessoa.

\section{4) [Clima e tempo]}

Contextos relacionados à ação, ao estado ou ao processo que envolvem as condições atmosféricas que exercem influências sobre a vida na Terra, as características específicas das regiões e as condições meteorológicas. 


\section{5) [Crime e violência]}

Contextos relacionados à ação, ao estado ou ao processo que envolvem a transgressão moral ou ética, socialmente rejeitada, seja por ação, seja por omissão, empregando força física ou psicológica, passiva de punição pela lei penal.

\section{6) [Educação]}

Contextos relacionados à ação, ao estado ou ao processo que envolvem desenvolvimento físico, intelectual, social e moral do ser humano, que assegure sua formação sócio-histórico-cultural, seja em ambiente familiar, seja em ambiente formal.

\section{7) [Esporte]}

Contextos relacionados à ação, ao estado ou ao processo que envolvem as práticas, individuais ou coletivas, de jogos e de exercícios físicos, seja com fins de recreação, seja com fins de condicionamento corporal para benefício da saúde, seja para competições esportivas.

\section{8) [Festas e festividades]}

Contextos relacionados à ação, ao estado ou ao processo que envolvem reuniões de pessoas com fins recreativos, enquadrando-se as festas familiares, as solenidades civis e as de caráter religioso.

\section{9) [Lazer]}

Contextos relacionados ao tempo utilizado para o ócio, o descanso e outras atividades prazerosas.

\section{0) [Moradia]}

Contexto relacionados à ação, ao estado ou ao processo de residir, habitar, viver em barraco, casa, apartamento, mansão ou outro lugar.

\section{1) [Profissão e trabalho]}

Contextos relacionados à ação, ao estado ou ao processo que envolvem ofício, trabalho, ocupação, atividade profissional em que uma pessoa visa obter recursos financeiros, como remuneração ou salário.

\section{2) [Relações sociais]}

Contextos relacionados à ação, ao estado ou ao processo que envolvem o convívio entre pessoas ou grupo de pessoas com interesses comuns, que se relacionam com fins particulares, profissionais, familiares, emocionais, de acordo com a cultura e a sociedade local. 


\section{3) [Saúde e doenças]}

Contextos relacionados à ação, ao estado ou ao processo que envolvem as condições físicas e psíquicas, proporcionando o bem-estar, e quando não estão equilibradas, provocam enfermidades, mal, moléstia aos seres vivos, podendo apresentar sintomas.

\section{4) [Tabuísmo]}

Contextos relacionados à ação, ao estado ou ao processo que envolvem comportamentos, palavras ou expressões consideradas chulas, grosseiras ou ofensivas em determinados contextos sociais.

\section{5) [Trânsito e transporte]}

Contextos relacionados à ação, ao estado ou ao processo que envolve movimentação, trajeto, passagens ou deslocamento em determinado lugar, com utilização ou não de veículos.

\section{6) [Vestimentas e indumentárias]}

Contextos relacionados à ação, ao estado ou ao processo que envolvem o hábito sociocultural de utilizar roupas e acessório para vestir o corpo ou partes do corpo.

\section{7) [Viagem]}

Contextos relacionados à ação, ao estado ou ao processo que envolvem deslocamentos de um lugar para outro, relativamente distante, normalmente com finalidade profissional ou de entretenimento e turismo.
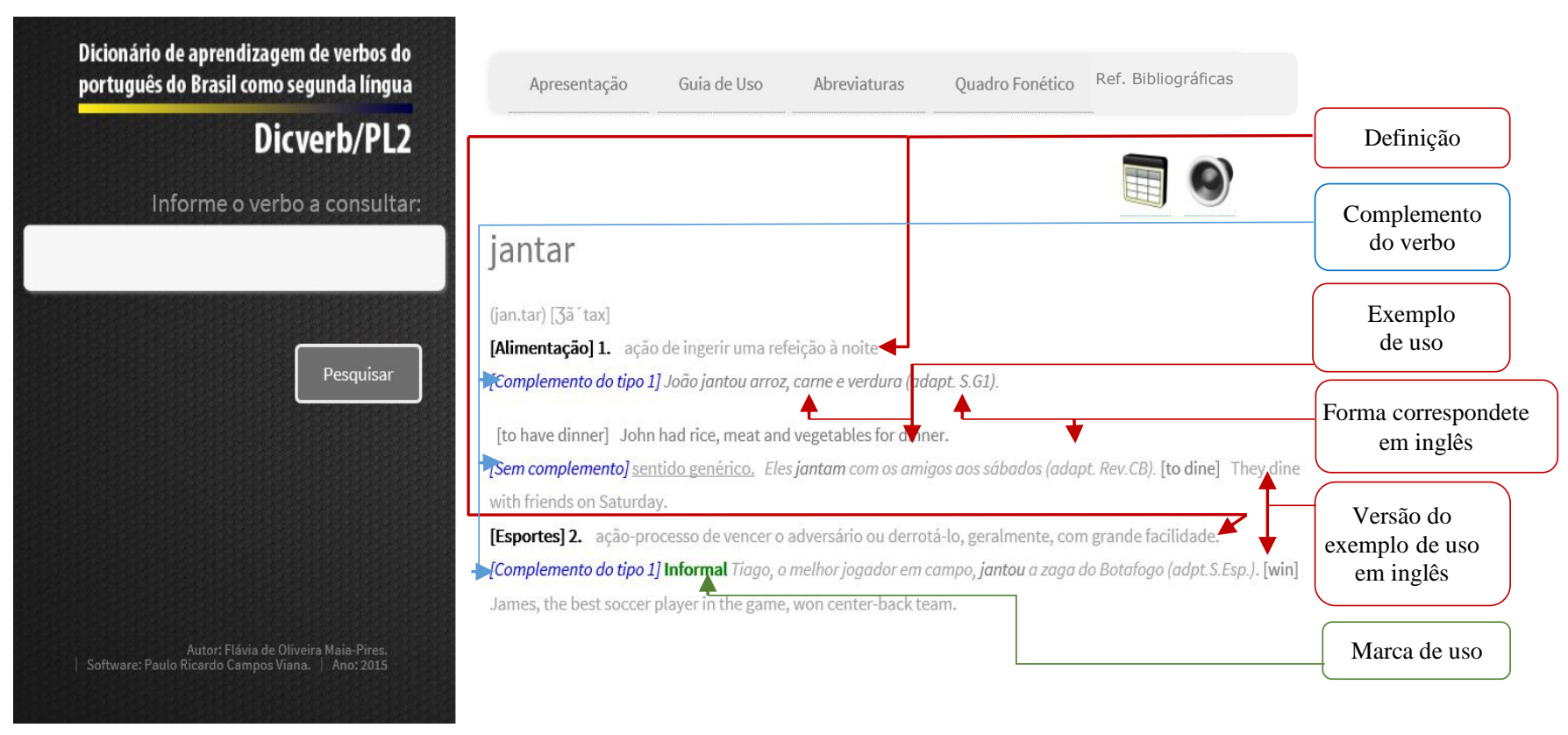

Figura 29: Página do verbete jantar do Dicverb/PL2 - definição, complementos, exemplos de uso e correspondente em inglês. 
g) Definição, explicitação semântica dos usos contextualizados, localizada após a indicação do contexto e numerada. Indicativo do(s) significados(s) pertinente(s) dos itens lexicais. Estão descritas com adaptações das definições apresentadas no Dicionário de uso do Português do Brasil (2002), no dicionário Houaiss (2009) e no dicionário Aulete digital (2014). As acepções são adaptadas para apresentar:

$\checkmark$ Tipo do verbo (ação, ação-processo, estado, processo ou suporte);

$\checkmark$ Significado do verbo;

$\checkmark$ Complementos que cooperam para o significado apresentado pelo verbo no contexto;

$\checkmark$ Preposição que liga o verbo ao seu complemento interno nos casos de C2 ou C3.

h) Complemento verbal, indicativo da relação entre o verbo e a exigência verbal para completar seu significado, quer dizer, a recusa e a aceitação livre dos complementos pelo verbo, em vista da especificação dos complementos verbais. "Implica a valência verbal, isto é, a capacidade de os verbos abrirem casas para preenchimento por termos (sujeito e complemento), compondo-se a estrutura argumental" (NEVES, 2000, p. 28). Na proposta do Dicverb/PL2, os tipos dos complementos verbais são apresentados de acordo com a associação dos significados correspondentes, aparecem na cor azul e entre colchetes [ ]. Serão marcados os complementos internos dos verbos ou a ausência desses complementos, do seguinte modo:

Sem complemento $=$ para verbos que não exigem complementos interno $-\mathrm{C} 0$;

$\checkmark$ Complemento $1=$ complemento interno ligado ao verbo sem preposição $-\mathrm{C} 1$;

$\checkmark$ Complemento 2 = complemento interno ligado ao verbo por preposição $-\mathrm{C} 2$;

$\checkmark$ Complemento $3=$ complemento interno ligado ao verbo por preposição $-\mathrm{C} 3$, para os verbos tetravalentes como o verbo transferir.

i) Exemplos de uso, registrados em itálico, enquanto a ocorrência do verbo está em itálico e em negrito; indicativo do uso do item lexical no contexto como ferramenta de aprendizagem. Os exemplos foram recolhidos para demonstrar o uso real dos verbos no cotidiano dos brasileiros. Por isso, foram selecionados de notícias divulgadas na internet, preferencialmente de sites de jornais ou de revistas de grande circulação, de sites especializados e de filmes brasileiros contemporâneos de grande bilheteria, de acordo com os 17 contextos abordados. Adaptamos os exemplos para a inclusão dos complementos 
internos, quando são exigidos pelos verbos, mas não estão explícitados nos enunciados reais. Essa adaptação visa oferecer subsídios para a aprendizagem do léxico pelo aprendiz iniciante. Os nomes pessoais citados nos exemplos originais foram substituídos por nomes fictícios ou por representantes genéricos do item lexical para que fosse respeitada a privacidade de pessoas citadas nas matériais originais.

j) Forma correspondente em inglês, indica o item lexical correspondente na língua inglesa de acordo com o significado relacionado ao contexto linguístico e ao contexto de uso do verbo em português; apresenta-se entre colchetes [ ].

k) Versões dos exemplos de uso, indicativo da versão do exemplo de uso do enunciado em inglês. A versão foi elaborada para transmitir o significado do enunciado ao aprendiz iniciante.

I) Marcas de uso, indicativo das variantes no espaço, no tempo ou no registro mais ou menos formal. As marcas de uso obedecem às dicotomias formal e informal, ao uso nacional e uso regional, sendo marcados os usos informal e regional. Destacado na cor verde.

\subsection{Amostragem de verbetes do Dicverb/PL2}

A proposta do Dicionário de aprendizagem de verbos do português do Brasil como L2 -Dicverb/PL2 foi elaborada a partir de pressupostos teóricos e metodológicos da Lexicologia e da Lexicografia, direcionada a um público-alvo específico. O corpus inicial forneceu 895 verbos para compor o dicionário. Entretanto, durante a pesquisa, identificamos verbos que se apresentaram nas definições dos dicionários consultados e, por isso, foram incorporados ao corpus, como, por exemplo: o verbo corromper, que aparece na descrição do verbo subornar, na análise do enunciado Motorista subornou policial para não ser multado. Atualmente o número de verbos que compõe o corpus é 899; prevemos que, ao longo do processo de informatização, serão identificados novos verbos, assim, estabelecemos a quantidade máxima de 1000 verbos. Esse número somente será alterado se for para distinguir verbos homógrafos.

Assim sendo, apresentamos a seguir uma amostragem de verbetes selecionados, a partir dos verbos que foram demonstrados durante esta tese. 


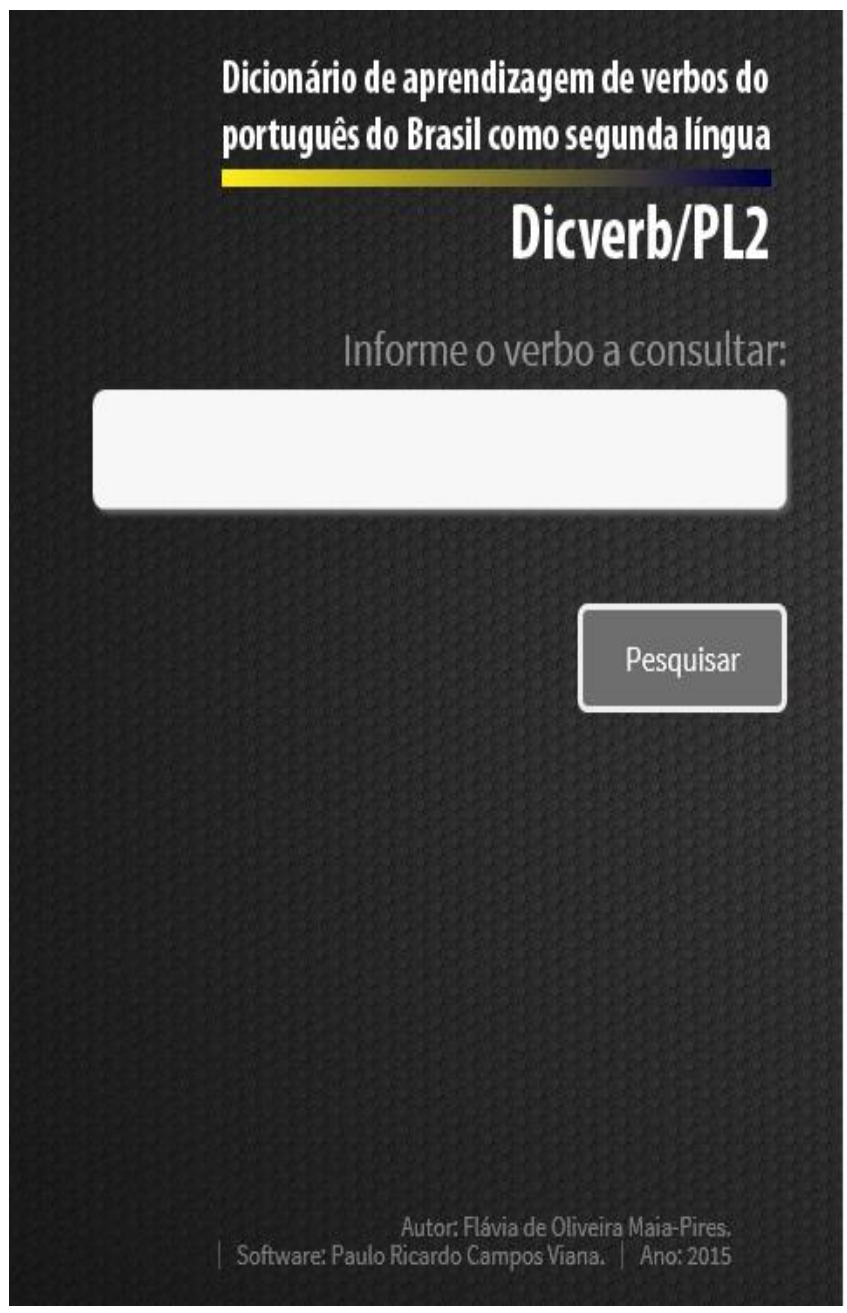

Apresentação Guia de Uso Abreviaturas Quadro Fonético Ref. Bibliográficas

\section{国}

beber

(be.ber) [be'bex]

[Alimentação] 1. ação de ingerir líquidos

[Complemento do tipo 1] Com o tempo seco, beba 2 litros de água por dia (S.G1) [to drink] With dry weather, drink two liters of water a day.

[Festa e festividades] 2. ação de ingerir bebidas alcoólicas, embriagar-se

[Sem complemento] Adolescentes começam a beber cada vez mais cedo (Rev.Vj) [to drink (alcohol)] Adolescents start to drink at very young ages.

[Trânsito e transporte] 3. ação de consumir muito combustivel

[Complemento do tipo 1] 10 hábitos do motorista para que o carro beba menos combustivel (S.G1) [to use] 10 driver's habits so that the car uses less fuel. 
2) Verbete do verbo comer:

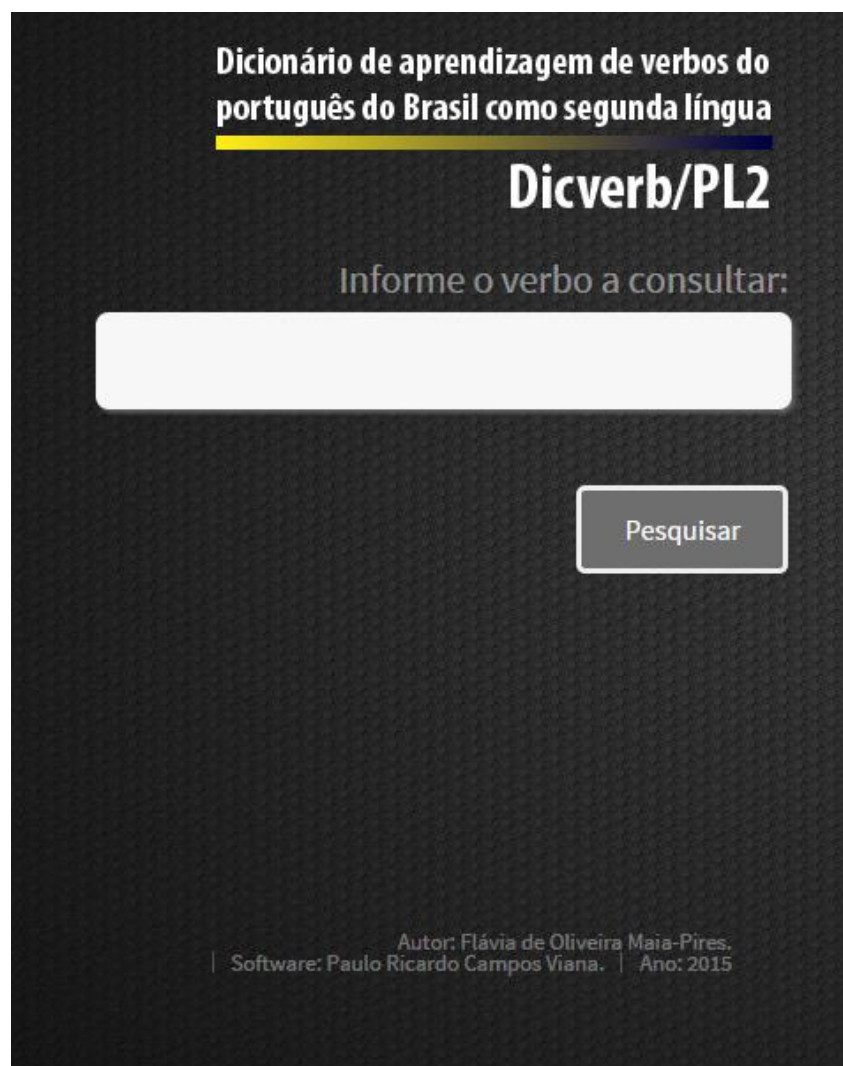

\section{Apresentação Guia de Uso Abreviaturas Quadro Fonético Ref. Bibliográficas}

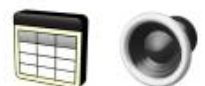

\section{comer}

(co.mer) [ko'mex]

[Alimentação] 1. alimentar-se (genérico)

[Sem complemento] Lugar para comer sem pressa, este restaurante mantém um atendimento simpático (Rev. CB) [to eat] Place to eat without hurry, this restaurant maintains a friendly service.

[Alimentação] 2. nutrir o corpo com alimento, ingerir alimento introduzido pela boca, mastigando e engolindo.

[Complemento do tipo 1] 0 Ator comeu carne recheada com patê de figado (adpt. S.G1). [to eat] The Actor ate meat stuffed with liver paté.

[Atividades domésticas] 3. destruir, danificar algo

[Complemento do tipo 1] A traça comeu a roupa que estava no armário (S.Gaz.GI). [to damage] The moth damaged clothes in the closet

[Educação] 4. excluir, eliminar, omitir algo

[Complemento do tipo 1] Informal 0 filho inventa grafias, "come" letras - escrevendo boneca apenas com as letras "bnc (Rev. Crsc.). [to eliminate] The son invents spellings, eleiminate letters - writing doll only with the letters "do".

[Lazer] 5. eliminar algo em partidas de jogos lúdicos para vencer

[Complemento do tipo 1] Ganha o jogo quem comer todas as peças do adversário (S.Gbook). [to eliminate] Win the game who eliminate all the opponent's pieces.

[Profissão e trabalho] 6. dilapidar, cosumir (dinheiro, salário, tempo) (

[Complemento do tipo 1] Inflação acelerada come salário do trabalhador (S. R7.N). [to consome] Accelerating inflation consumes worker's salary.

Tabuísmol 7. copular, possu

[Complemento do tipo 1] Informal Seu Jorge, você já comeu uma loira? (Fil.Br) [to have sex] Mr. Jorge, have you ever had sex with a blonde? 
3) Verbete do verbo matar:

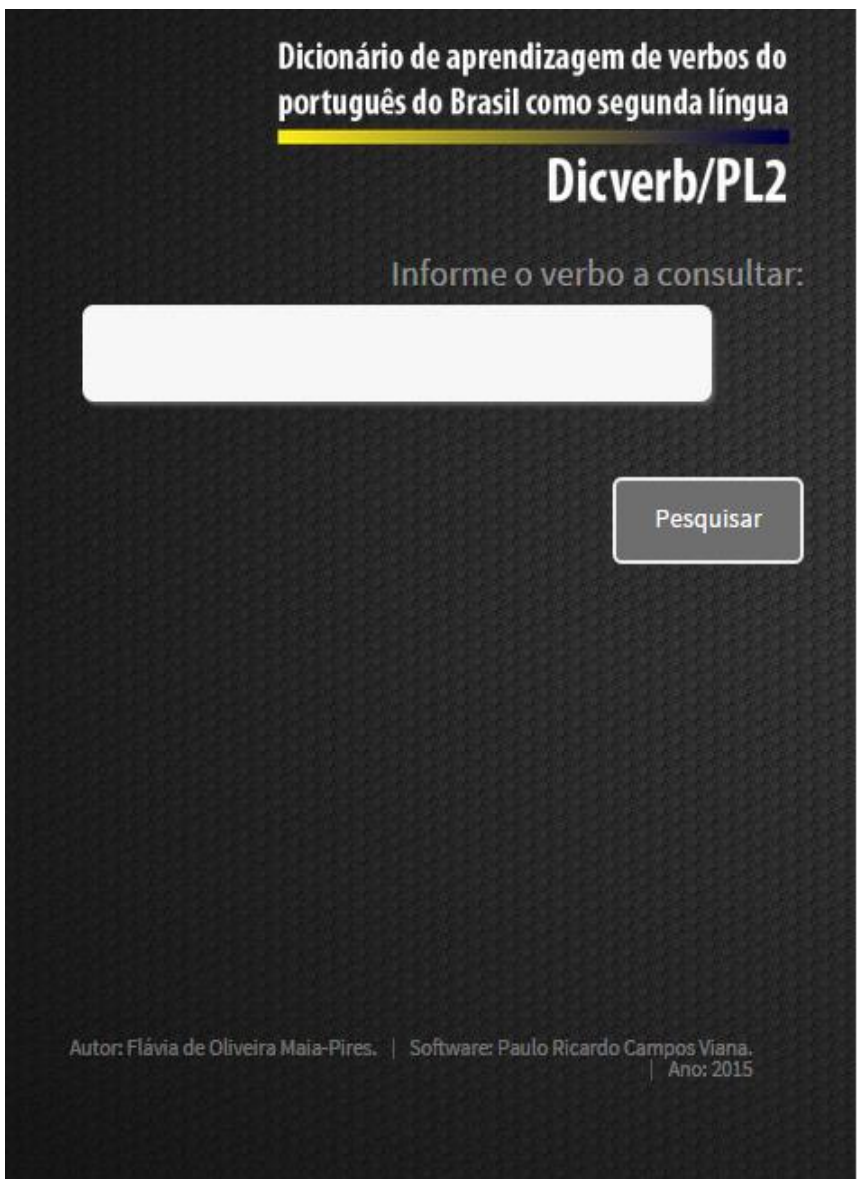

Apresentação Guia de Uso Abreviaturas Quadro Fonético Ref. Bibliográficas

刍

matar

(ma.tar) [ma'tax]

[Alimentação] 1. alimentar, extinguir a fome,

[Complemento do tipo 1] Menino mata fome de jornalistas na chegada de Honduras a Porto Feliz (S.Esp). [to feed] Boy

feeds the journalists who arrived from Honduras to Porto Feliz.

[Crime e violência] 2. assassinar, tirar a vida (homem, animais, plantas....

[Complemento do tipo 1 B Bandido mata policial militar e resgata traficante de hospital em Niterói - Rio de Janeiro

(S.JExt.). [to kill] Villanin kills PM (policeman) and rescues hospital dealer in Niterói - Rio de Janeiro.

[Esportes] 3. amortecer o impacto

[Complemento do tipo 1] Informal Alexandre Pato mata a bola no peito e invade a área do Palmeiras (S.Esp.PI). [to

control] Alexandre Pato controls ball in his chest and invades the area of Palmeiras.

[Profissão e trabalho] 4. sacrificar-se

[Complemento do tipo 1] Não se mate de trabalhar tentando ficar rico (S.J.BdRS). [to sacrifice, to kill] Do not sacrifice yourself of working to get rich.

[Relações sociais] 5. causar sofrimento a alguèm, magoar, ofender alguém

[Complemento do tipo 1] As palavras matam as pessoas, por isso recomendo que as pessoas não insultem umas as

outras (S.N.Uol). [to hurt] Words hurt people, sol recommend that people do not insult each other.

[Saúde e doenças] 6. contribuir para que alguém ou algo morra, levar à morte, acarretar a destruição de alguém.

[Complemento do tipo 1] Ebola já matou mais de 1000 pessoas na Africa (S.G1). [to kill] Ebola has killed more than 1,000 people in Africa. 


\section{Continuação do verbete tomar:}

[Crime e violência] 6. ação-processo de roubar algo/alguma coisa de alguém.

[Complemento do tipo 2] o ladão tomou a bolsa da mulher (S.G1). DE $+\mathrm{a}=\mathrm{da} \rightarrow$ posse [to steal] The thief stole the woman's purse.

[Educação] 7. ação-processo de receber por merecimento nota ou advertência.

[Complemento do tipo 1] 0 aluno tomou zero na prova (S. Port. Ap). [to get on] The student get zero on the test

[Saúde e doenças] 8. ação de ingerir medicamentos por via oral ou não.

[Complemento do tipo 1] Não tome remédio sem o conhecimento do seu médico (Rev.Saú) [to take] Do not take medicine without the talking to your doctor.

[Saúde e doenças] 9. processo de absorver luz solar por se expor ao sol.

[Complemento do tipo 1] Verão 2013: tome sol na medida certa (Rev.Mul). [to sunbathe] Summer 2013: sunbathe just right.

[Trânsito e transporte] 10. ação de embarcar em transporte, ônibus, táxis, avião, trem.

[Complemento do tipo 1] Estudante toma três ônibus diariamente entre Igarassu e Jaboatão (S.G1) [to take] Student takes three buses daily from Igarassu to Jaboatão. 
4) Verbete do verbo vestir:

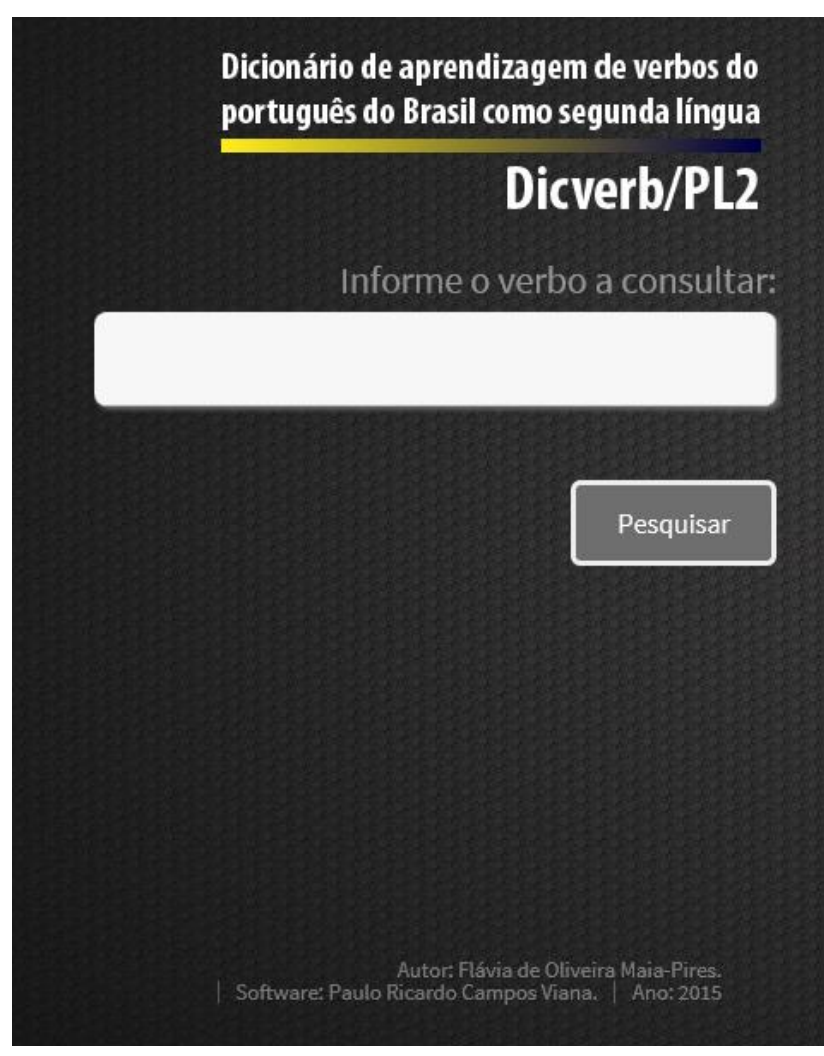

Apresentaçåa

Guia de Uso

Abreviaturas

Quadro Fonético

Bibliografias

\section{vestir}

(ves.tir) [ves'tix]

[Esportes] 1. fazer parte de uma equipe ou de uma empresa com propósito de beneficiá-la.

[Complemento do tipo 1] Vestir a camisa do Sampaio Futebol Clube já é uma grande motivação (adap.S.Esp) [to be a part of] Be a part of the team Sampaio is already a great motivation.

[Vestimenta e indumentárias] 2. cobrir o corpo com roupas, usar roupas.

[Complemento do tipo 1] Jennifer vestiu um minivestido de cor laranja (S.JR7.CP). [to wear] Jennifer wore a orange minidress. 


\subsection{Síntese de capítulo}

Neste capítulo, apresentamos a proposta do Dicionário de aprendizagem de verbos do português do Brasil como segunda língua - Dicverb/PL2 e uma amostra de verbetes. Expusemos as fontes que foram utilizadas para a construção do banco de dados, para armazenamento dos dados e para o desenvolvimento do software do dicionário. Apresentamos a macroestrutura e a microestrutura que compõem a proposta e o mecanismo de inserção dos elementos estruturais do dicionário. A seguir, apresentaremos as considerações finais. 


\section{CONSIDERAÇÕES FINAIS}

O estudo feito durante o percurso desta pesquisa permitiu-nos avaliar a natureza e a multifuncionalidade das obras lexicográficas, que estão além do que os aspectos físicos podem demonstrar. São obras que registram a complexidade do ser humano e da sociedade em que vive, considerando os componentes biológicos, psicológicos, sociais, políticos, históricos e geográficos.

O objeto de estudo desta tese demonstrou que o verbo, componente linguístico que atua como elo entre as entidades do mundo real e do mundo imaginário do ser humano, possibilita o movimento dos pensamentos expressos nos enunciados. Os pensamentos não são estáticos, mudam assim como a sociedade e o indivíduo.

Entendemos que o objetivo desta pesquisa foi alcançado quando apresentamos ao final a proposta do Dicionário de aprendizagem de verbos do português do Brasil como segunda língua - Dicverb/PL2 - como uma obra lexicográfica especialmente concebida para um público que se encontra em situação de aprendizagem de segunda língua (L2). Para isso, identificamos princípios teóricos a respeito da natureza do verbo que atuam no evento comunicativo, tais como o compontente conceitual, o componente contextual, o componente gramatical e o componente de saída.

A análise demonstrou que as operações sintático-semânticas, que descrevem os verbos como de ação, de processo, de estado, de estado-processo em conjunto com as informações morfossitáticas, que descrevem número, pessoa, tempo e modo dos verbos, são produtos de fatores pré-linguísticos e linguísticos. A funcionalidade do componente contextual evidenciou-se durante a análise, pois coopera com o componente gramatical, convertendo as representações pragmáticas e semânticas em morfossintática e fonológica. Desse modo, o resultado das combinações sintático-semânticas de acordo com os 17 contextos abordados nesta pesquisa permitiu-nos identificar o contexto como agente contribuidor para a significação, por isso incluímos na estrutura do Dicverb/PL2 os contextos do cotidiano dos brasileiros para fornecer informações relevantes, disponíveis no universo material, como número de participantes, tempo e espaço, e no universo não-material, como organização social e comportamento da comunidade de fala, relacionados a contextos específicos.

Assim sendo, elaboramos uma proposta para fornecer ao aprendiz iniciante de PSL informações que o auxiliem no conhecimeneto dos verbos da língua portuguesa que 
contemplam aspectos de fonética, de morfologia, de sintaxe, de semântica, de pragmática da língua portuguesa e da cultura brasileira por meio do léxico. Consideramos na elaboração do Dicverb/PL2 a organização hierárquica do modelo da Gramática Discursivo-Funcional que inclui o componente gramatical, o componente contextual, o componente conceitual e o componente de saída, os quais se interligam por meio de formulação e de codificação no funcionamento da língua. Esses componentes são abordados na microestrutura como tipos de complementos verbais, contextos situacionais, exemplos de uso dos verbos, marcas de uso, acepções, transcrição fonética, recurso de áudio. A proposta poderá ser adaptada para atender a demanda de outros públicos.

Aspectos da sociedade e da cultura brasileira foram observados durante o processo de pesquisa, assim, selecionamos contextos do cotidiano dos brasileiros em que os verbos ocorrem, registrados em revistas, jornais e filmes nacionais. Os contextos identificados foram alimentação, atividades comerciais, atividades domésticas, clima e tempo, crime e violência, educação, esportes, festas e festividades, lazer, moradia, profissão e trabalho, relações sociais, saúde e doenças, tatuísmos, trânsito e transportes, vestimentas $e$ indumentárias e viagens e hospedagem. $\mathrm{O}$ uso de ferramentas para processamento de dados permitiu-nos coletar 8.452 itens lexicais dos quais 895 eram verbos, a partir dos 66 textos que abordavam os 17 contextos identificados nesta pesquisa.

Cotejamos algumas obras para confrontar a composição da macroestrutura e da microestrutura. O cotejo feito serviu de base para identificarmos as principais características que norteariam o Dicverb/PL2. Por fim, identificamos a tecnologia como aliada na inovação de dicionários para promover melhor uso e interação entre o material pedagógico e aprendiz da língua.

Em vista disso, a proposta é de caráter científico e social, pois é elaborada dentro de princípios teóricos, metodológicos e empíricos, concebida para contribuir com o preenchimento da lacuna dos estudos lexicológicos e lexicográficos para aprendizagem do Português do Brasil como segunda língua.

Para isso, conforme apresentamos nos capítulos desta pesquisa, organizados para demonstrar o caminho percorrido, foram estudados os atributos do verbo, com ênfase na tipologia semântica e sintática, com vistas a compreender a centralidade dessa categoria lexical na produção e na compreensão de enunciados. Fizemos um estudo sobre a produção e a tipificação das obras lexicográficas ao longo da história da lexicografia portuguesa. Estudamos os atributos do léxico, sua relação com os dicionários e com os usuários e 
identificamos a necessidade de compreender as diferenças entre segunda língua (L2) e língua estrangeira (LE) e a necessidade de materiais específicos para cada público.

Por fim, identificamos a necessidade de agregar à proposta os avanços tecnológicos que se destacaram como ferramenta útil para a elaboração e a divulgação do conhecimento adquirido no processo acadêmico. Assim, o Dicverb/PL2 será disponibilizado gratuitamente via internet, o que possibilitará que a sociedade tenha mais um meio de acesso ao conhecimento linguístico. 


\section{REFERÊNCIAS BIBLIOGRÁFICAS}

ABREU, Sabrina Pereira de. O registro de termos em dicionário geral de língua. Anais do IX Encontro do CELSUL . Palhoça, SC, out. 2010

AITCHISON, Jean. Words in the mind. An introduction to the mental lexicon, Oxford, Blackwell, 1994.

ALTURO, N; KEIZER, E; PAYRATÓ, L. The interction between contexto and gramar in funciona discourse: introduction. Pragmatics 24:2.185-201 (2014). Disponível em: http://ipra.ua.ac.be/download.aspx?c=*HOME\&n=1480\&ct=1480\&e=12318 Acesso 12.junho.2014.

ALVES, E. Categorias lexicais e funções na linguagem de especialidades da economia. Tese (doutorado) - Universidade de Brasília, Instituto de Letras, Departamento de Linguística, Português e Línguas Clássicas, Programa de Pós-Graduação em Linguística, $2006 . \quad$ Disponível em: http://repositorio.unb.br/bitstream/10482/3305/1/2006_Elisabeth\%20Alves.pdf Acesso. 20.maio. 2014.

AUROUX Sylvain. A Revolução Tecnológica da Gramatização. Tradução: Eni Orlandi. Campinas: Editora da Unicamp, 1992.

AYROSA, P. Vocabulário na Língua Brasílica. São Paulo: Coleção Departamento de Cultura, vol XX, 1938.

BARROS, L. A. Curso básico de Terminologia. São Paulo: Editora da Universidade de São Paulo, 2004.

BASILIO, M. Teoria Lexical. Editora Atica, Brasil. 1999.

BASÍLIO, M. Formação de classes de palavras no português do Brasil. $2^{\mathrm{a}}$ ed. Editora Contexto, São Paulo, 2006.

BECHARA, E. Moderna gramática portuguesa. Rio de Janeiro. Editora Nova Fronteira, Ed. 37, 2009.

BIDERMAN, M. T. C. As ciências do léxico. In: OLIVEIRA, A. M. P. P. de; ISQUERDO, A. N.(Orgs.) As ciências do léxico: Lexicologia, lexicografia, terminologia(as). 2. ed. Campo grande: Ed UFMS, 2001a, p. 13-22.

BIDERMAN, M. T. C. Os dicionários na contemporaneidade. In: OLIVEIRA, A. M. P. P. de; ISQUERDO, A. N.(Orgs.) As ciências do léxico: Lexicologia, lexicografia, terminologia(as). 2. ed. Campo grande: Ed UFMS, 2001b, p. 131-144.

BIDERMAN, M. T. C. Teoria lingüística: teoria lexical e lingüística computacional. 2ed. Editora Martins Pontes. São Paulo, 2001. 
BIDERMAN, M.T.C. A ciência da lexicografia. In.: ALFA: Revista de Linguística. Universidade Estadual Paulista, São Paulo 28(suplemento), 1984a, p. 1-26.

BIDERMAN, M.T.C. O dicionário padrão da língua. In.: ALFA: Revista de Linguística. Universidade Estadual Paulista, São Paulo 28(suplemento), 1984b, p. 27-43.

BORBA, F. da S. Uma gramática de valência para o português. São Paulo. Editora Ática, 1996.

BORBA, F. da S. Organização de dicionários: uma introdução à lexicografia. Editora UNESP. São Paulo, 2003.

BRASIL. MINISTÉRIO DA EDUCAÇÃO. Secretaria de Educação Básica Com direito à palavra: dicionários em sala de aula / [elaboração Egon Rangel]. - Brasília : Ministério da Educação, Secre- taria de Educação Básica, 2012.

BRASIL, MEC/SEF. Parâmetros curriculares nacionais. Brasília: SEF/MEC, 1998.

CABRÉ, M. T. La terminologia. Teoria, metodogía, aplicaciones. Barcelona. Editora Antária/Empúries, 1993.

CAMACHO, R. G. Classes de palavras na perspectiva da Gramática DiscursivoFuncional: o papel da nominalização no continuum categorial. São Paulo. Editora UNESP, 2011.

CANÇADO, M. Manual de semântica: noções básicas e exercícios. Belo Horizonte. Editora UFMG, 2005.

CARVALHO, O. L. de S. Dicionários escolares: definição oracional e texto lexicográfico. In.: CARVALHO, O. L. de S e BAGNO, M. (orgs.) Dicionários escolares: políticas, formas \& usos. São Paulo: Parábola Editorial, 2011.

CARVALHO, O. L. de S.; MARINHO, M. L. Contribuições da lexicografia ao contexto educacional bilíngüe de surdos. In: SALLES, H. M. M. L. de A. (Coord.). Bilingüismo dos surdos: questões lingüísticas e educacionais. Goiânia: Cânone, 2007.

CASSEB-GALVÃO, V; LIMA-HERNANDES, M. C. O equilíbrio na mudança linguística: a gradualidade em processo. In.: SOUZA, E. R. de (org.) Funcionalismo linguístico: novas tendências teóricas. São Paulo. Editora Contexto, 2012.

CASTILHO, A. T de. Nova gramática do português brasileiro. São Paulo. Editora Contexto, 2010.

CHAFE, W. L. Significação e estrutura linguística. Wallace L Chafe; tradução de Maria Helena de Moura Neves, Odette G. L Altmann de S. Campos e Sonia Veasey Rodrigues. Rio de Janeiro: Livros Técnicos e Científicos, 1979.

CONNOLLY, J. H. Context in Funcitonal Discourse Grammar. Alfa - Revista de linguística, São Paulo, v. 51 (2), 2007. 
CORNISH, F. Text and discourse: Discourse anaphora and the FDG Contextual Component. In: KEIZER, E.; WANDERS, G. (Eds.). Web Papers in Functional Discurse Grammar. Amsterdam, v. 82, 2009. Disponível em: http://home.hum.uva.nl/fdg/working_papers/WPFDG-82_Cornish.pdf Acesso em: 12. nov.2013.

CORRÊA, L. Dicionário eletrônico onomasiológico semasiológico do português brasileiro/espanhol rioplatense para o Mercosul. In: ISQUERDO, A. N.; SEABRA, M. C. T. C. de. (Orgs.). As ciências do léxico: lexicologia, lexicografia, terminologia. Volume VI. Campo Grande: UFMS, 2012.

CORREIA, M. Os dicionários portugueses. Editora Caminho. Faculdade de Letras da Universidade de Lisboa ILTEC. Lisboa, 2009.

CASARES, J. Semântica e lexicografia. Trad. De Balbina Lorenzo Feijóo-Hoyos. In.: BIDERMAN, M.T. C (org). Alfa Revista de Linguística: lexicografia e lexicologia. UNESP, v. 28 - suplemento. São Paulo, 1984.

CRISTÓFARO-SILVA, Thaïs; YEHIA, Hani Camille . Sonoridade em Artes, Saúde e Tecnologia. Belo Horizonte: Faculdade de Letras, 2009. Disponível em http://fonologia.org. ISBN 978-85-7758-135-1.

CUENCA, M. J. e HILFERTY, J. Introducción a la Linguistica Cognitiva. Editorial Ariel Linguistica. Barcelona, 1999.

DIK, S. C. The theory of Functional Grammar. Part 1 : The structure of the clause . 2nd ed. Berlin: Mouton de Gruyter, 1997.

DURAN, M. S. Dicionários bilíngües pedagógicos: análise, reflexões e propostas / Magali Sanches Duran - UNESP - São José do Rio Preto, 2004. Disponível em: http://base.repositorio.unesp.br/bitstream/handle/11449/86601/duran_ms_me_sjrp_prot.pdf ?sequence $=1 \&$ isAllowed=y Acesso em 25 de set. de 2014.

DURAN, M. S.; XATARA, C. Critérios para categorização de dicionários bilíngues. In.: ISQUERDO, A. N; ALVES, I. M. As ciências do léxico: lexicologia, lexicografia, terminologia, volume III. Campo Grande, MS: Editora UFMS; São Paulo: Humanitas, 2007.

DURAN, M. S.; XATARA, C. Lexicografia Pedagógica: atores e interfaces. DELTA. Documentação de Estudos em Lingüística Teórica e Aplicada, v. 23, 2007, p. 203-222. Disponível em: http://www.scielo.br/pdf/delta/v23n2/a02v23n2.pdf acesso em: 20 de set. 2014.

FAULSTICH, E. Glossário de termos empregados nos estudos da Terminologia, da Lexicografia e da Lexicologia. In: Série Léxico \& Terminologia. Brasília: Centro Lexterm, Universidade de Brasília, inédito, 2014.

FAULSTICH, E. Características conceituais que distinguem o que é de para que serve nas definições de terminologias científica e técnica. In: Encontro intermediário do grupo de trabalho de lexicologia, lexicografia e terminologia da associação nacional de pós-graduação 
e pesquisa em letras e linguística (ANPOLL), 9., 2013a. Disponível em: <http://www.letras.ufmg.br/gtlexNovo/ >. Acesso em: 20 set. 2014.

FAULSTICH, E. Avaliação de dicionários: uma proposta metodológica. Organon: revista da Faculdade da Filosofia da Universidade Federal do Rio Grande do Sul, v. 25, n. 50, 2011.

FAULSTICH, E. Para gostar de ler um dicionário. In: RAMOS, C. de M. de A; BEZERRA, J. de R. M.; ROCHA, M. de F. S.. (Org.). Pelos caminhos da Dialetologia e da Sociolinguística: entrelaçando saberes e vidas. $1^{a}$ ed.São Luís: UFMA, 2010a, v. 1, p. 166185.

FAULSTICH, E. Análise operacional de esquemas contextuais: o campo lexical e a moldura. Acta Semiotica et Linguística, v. 15, p. 191-200, 2010 b.

FAULSTICH, E.; SANTOS, C. A desambiguação do item lexical levar: uma proposta de organização de verbete. In: ISQUERDO, A. N.; ALVES, I. M.. (Org.). As ciências do léxico: lexicologia, lexicografia, terminologia. $1^{\text {a }}$ ed.Campo Grande - MS;: UFMS, 2007, v. III, p. 247-260, 2007.

FAULSTICH, E.; MAIA-PIRES, F. de O. Aquisição do léxico na aprendizagem do Português como segunda língua. Projeto de Iniciação Científica (PIC), CNPq/UnB. Brasília, 2006.

FAULSTICH, E. Papel político-lingüístico do Brasil no contexto de um novo mapa de interação social. In.: Seminário idioma e soberania nossa língua nossa pátria 500 anos, 2000. Disponível em http://www2.camara.leg.br/acamara/conheca/historia/historia/cdnos500anos/seminarios/ semin2/fala8.html. Acessado em 25.maio.2013.

FAULSTICH, E. Perspectivas da atividade terminológica no Brasil. Terminologia: Questões Teóricas Métodos e Projetos, Lisboa, 1998.

FAULSTICH, E. Da lingüística histórica à terminologia. In: Revista Investigações Lingüística e Teoria Literária. Ed. Universitária. V. 7. Recife, 1997.

FAULSTICH, E. Redes de remissivas em um glossário técnico. In: Léxico e Terminologia (Coletânea de Textos). Universidade de Brasília, 1993, p. 174-184.

FAULSTICH, E. Metodologia para projeto terminográfico. UnB/IBICT. Brasília, 1990.

FARIAS, E. M. P. Uma breve história do fazer lexicográfico. In. Revista Trama. Vol. 3 n5, 2007, p. 89-98.

GOMES, P. V. N. Aquisição lexical e uso do dicionário escolar. In. CARVALHO, O. L. de S. e BAGNO, M. (orgs.) Dicionários escolares: políticas, formas \& usos. São Paulo: Parábola Editorial, 2011.

GOMES, P. V. N. O processo de aquisição lexical na infância e a metalexicografia do dicionário escolar. (tese de doutorado) Universidade de Brasília, Brasília, 2007. 
GRANNIER, D. M. Perspectivas na formação do professor de portugues como segunda língua. In: Cadernos do Centro de Línguas, 2001, São Paulo, 2001

GUERRA, A. M M et al. Lexicografia española.Espanha, Arial, 2003.

HAENSCH, G. Los diccionarios del español en el umbral del siglo XXI. 1 ed. Salamanca: Ediciones Universidad de Salamanca, 1997.

HAENSCH, G. Aspectos prácticos de la elaboración de diccionarios. In: HAENSCH, G.; WOLF; Lothar; ETTINGER, Stefan; WERNER, Reinhold. La lexicografía: de la lingüística teórica a la lexicografía práctica. Madrid: Gredos, 1982. p. 395-534.

HENGEVELD, K. The architexture of a Functional Discourse Grammar. In: MAKENZIE, J. L; GÓMEZ-GONZÁLEZ, M. A. (ED.) A New architecture for Functional Grammar (Functional Grammar Series 24). Berlin: Mouton de Gruyter, 2004.

HANGEVELD, K. Epilogue. In: MACKENZIE, J. L; GÓMEZ-GONZÁLEZ, M. A. (org.) A new architexture for Functional Discourse Grammar (Functional Grammar Series 24). Berlin: Mouton de Gruyter, 2004.

HENGEVELD, K; MACKENZIE, J.L. Functional Discourse Grammar. In: Heine, B; NARROG, H (Ed.). The Oxford Handbook of Linguistic Analysis. Oxford University Press, 2010.

HENGEVELD, K; MACKENZIE, J.L. Functional Discourse Grammar: a typologicallybased Theory of Language Structure. Oxford. Oxford University Press, 2008.

HENRIQUES, C. C. Léxico e Semântica: estudos produtivos sobre palavra e significação. Rio de Janeiro, Editora elsevier, 2011.

HONÓRIO, Maria Aparecida. Novas leituras sobre o Brasil: a construção de um saber lexical no processo de escolarização indígena. Nunes, José Horta. História do saber lexical e constituição de um léxico brasileiro / José Horta Nunes, Margarida Petter. - São Paulo: Humanitas / FFLCH / USP: Pontes, 2002.

HYMES, D. Models of interaction of language and social life. In. GUMPERZ, J; HYMES D. Direrctions in sociolinguistics. New York: Rinehart \& Winaron, 1972.

ILARI, Rodolfo. Linguística românica. São Paulo, Ática. 1999.

ILARI, Rodolfo. “Aspectos de ensino do vocabulário”. In: A lingüística e o ensino da língua portuguesa. Ed. Martins Fontes, 1997.

ILARI, R.;GERALDI, J. W. A significação das palavras. In: Semântica. São Paulo: Editora Ática, 1998.

KRASHEN, S. Principles and Practice in Second Language Acquisition. Oxford: Pergamom Press. 1982. 
KRIEGER, M. G. A obra e o fazer dicionarísticos. Cadernos do IL. Porto Alegre: Universidade Federal do Rio Grande do Sul, n. 10, p. 9- 16, jun. 1993.

LARA, Luis Fernando. Teoría del diccionario monolíngue. México, El Colegio de México, 1996.

LAUFER, B. What is in a word that makes it hard ou easy: some intralexical factors that affect the learning of word. N SCHIMITT; MACHATHY M. Vocabulary, description, acquisitiona and pedagogy. CUP, Cambridge, 1997.

LEIRIA, Isabel. Léxico, aquisição e ensino do português língua não materna. Dissertação de Doutoramento em Linguística Aplicada, Universidade de Lisboa, 2001. em: http://cvc.instituto-camoes.pt/component/docman/doc_details.html?aut=2083 Acesso em: 20 de mar. 2013.

LEIRIA, Isabel. Português língua segunda e língua estrangeira: investigação e Ensino. In Idiomático 3, Instituto Camões. [http://www.institutocamoes. pt/cvc/idiomatico/03/portuguesLSeLE.pdf . 2004.

NEVES, M. H. M. Gramática de usos do português. São Paulo. Editora UNESP, 2000.

NEVES, Maria Helena Moura. A Gramática funcional. São Paulo, Martins Fontes, 1997.

MAIA-PIRES, F de O. Brasília em termos: um estudo lexical do Plano Piloto. Dissertação (mestrado) - Universidade de Brasília, Instituto de Letras, Departamento de Linguística, Português e Línguas Clássicas, Programa de Pós-Graduação em Linguística, 2009.

MAIA-PIRES, F. de O.; VILARINHO, M. M de O. O estudo do léxico no Curso de Letras $\mathrm{EaD}$ da UnB. In. VIEIRA, J. A; SILVA, F. C da. (orgs). O que a distância revela: reflexões da professores e estudantes do curso de Letras - EaD-UnB. Brasília. Editora Movimento, 2014.

MARTELOTTA, M. E.; ALONSO, K. S. Funcionalismo, Cognitivismo e a dinamicidade da língua. In.: SOUZA, E. R. de (org.) Funcionalismo linguístico: novas tendências teóricas. São Paulo. Editora Contexto, 2012.

MCCARTHY, M. Vocabulary. Oxford: Oxford University Press, 1990.

MIOTO, C; SILVA, M. C. F; LOPES, R. E. V. Novo manual de sintaxe. Flórianópois. Editora Insular, $2^{\mathrm{a}}$ edição, 2005.

MOURA, H.M.M. Significação e contexto. Uma introdução a questões de semântica e pragmática. Florianópolis. Ed. Insular, 1999.

NASCIMENTO, Maria Fernanda Barcelar do, M.L.G. Marques \& Maria Luísa Segura da Cruz. Português Fundamental: Vocabulário e Gramática. Centro de Linguística da Universidade de Lisboa. 1984. 
NASCIMENTO, Maria Fernanda Barcelar do, M.L.G. Marques \& Maria Luísa Segura da Cruz. Português Fundamental: Métodos e Documentos (2 vol.). Centro de Linguística da Universidade de Lisboa. 1987.

NUNES, José Horta. História do saber lexical e constituição de um léxico brasileiro / José Horta Nunes, Margarida Petter. - São Paulo: Humanitas / FFLCH / USP: Pontes, 2002.

OLIVEIRA, A. M. P. P. e ISQUERDO, Aparecida N. (org.) As Ciências do LéxicoLexicologia, Lexicografia, Terminologia. Campo Grande, MS: Editora UFMS. 1ª ed.1998; $2^{\mathrm{a}}$.ed. 2001.

OLIVEIRA, M. R. de. Tendências atuais da pesquisa funcionalista. In.: SOUZA, E. R. de (org.) Funcionalismo linguístico: novas tendências teóricas. São Paulo. Editora Contexto, 2012.

PEZATTI, E. G. A gramática Discursivo-Funcional e o contexto. In.: SOUZA, E. R. de (org.) Funcionalismo linguístico: novas tendências teóricas. São Paulo. Editora Contexto, 2012.

REY-DEBOVE, J. Etude linguistique et sémiotique des dictionnaires français contemporains. The Hague, Paris, Mouton, 1971.

REY-DEBOVE, J. Léxico e dicionário. (Tradução MORAIS, Clóvis Barleta) In. Revista Alfa. São Paulo, v.28, pp. 45-69. 1984.

RIO-TORTO, G; LOPES, A. C. M. O essencial sobre semântica. Lisboa. Editora Caminho, 2006.

SILVA, A. S. da. "O problema da polissemia à luz do verbo deixar”. In: A semântica de deixar: uma contribuição para a abordagem cognitiva em semântica lexical. Lisboa Fundação Calouste Gulbenkian, 1999.

SILVA, M. C. P da. Reflexões sobre o verbete dos dicionários bilíngues para fins pedagógicos. In.: ISQUERDO, A. N., FINATTO, M. J. B. As ciências do léxico: lexicologia, lexicografia, terminologia - Volume IV. Campo Grande, MS. Editora UFMS; Porto Alegre: editora da UFRGS, 2010.

STERN, H. H Fundamental concepts in language teaching, 1983. Disponível em: http://www. eduinnova.es/oct09/Interaction.pdf. EDUC 604: Theoretical Foundations of Teaching USA, Foris Publications, 1983.

TARP, S. Desafíos teóricos y prácticos de la lexicografía de aprendizaje. In.: XATARA, C BEVILACQUA, C. E HUMBLÉ, P (org.) Lexicografia pedagógica pesquisas $e$ perspectivas. Florianópolis. UFSC/NUT, 2008.

TOSQUI, P. Advérbios Modalizadores: subsídios para Dicionários Bilíngues. Araraquara. 144 p. Dissertação (Mestrado em Letras) FCL-UNESP, 2002. 
TOSQUI, P. Advérbios modalizadores afetivos em dicionários bilíngues inglês-português. In.: ISQUERDO, A. N., KRIEGUER, M. da G. (org.). As ciências do léxico: lexicologia, lexicografia, terminologia, volume II. Campo Grande, MS: Ed. UFMS, 2004.

VERDELHO, Telmo. Dicionários portugueses, breve história. In.: NUNES, José Horta. História do saber lexical e constituição de um léxico brasileiro / José Horta Nunes, Margarida Petter. - São Paulo: Humanitas / FFLCH / USP: Pontes, 2002.

VIEIRA, R.; LIMA, V. L. S. de. Linguística Computacional: Princípios e Aplicações. 2001.

VIGOTSKY, L. S. Pensamento e linguagem. São Paulo. Martins Fontes, 1993.

VILARINHO, Michelle Marchado de Oliveira. Proposta de dicionário informatizado analógico de língua portuguesa. Tese (doutorado) - Universidade de Brasília, Instituto de Letras, Departamento de Linguística, Português e Línguas Clássicas, Programa de PósGraduação em Linguística, 2013. Disponível em: http://repositorio.unb.br/bitstream/10482/15142/1/2013_MichelleMachadoOliveiraVilarinh o.pdf. Acessado em: 20 de jun. 2014.

WERNER, R. Léxico y teoria general del lenguaje. In.: In: HAENSCH, G.; WOLF; Lothar; ETTINGER, Stefan; WERNER, Reinhold. La lexicografía: de la lingüística teórica a la lexicografía práctica. Madrid: Gredos, 1982. p. 395-534.

XATARA, Claudia; BEVILACQUA, Cleci Regina e HUMBLÉ, Philippe René (orgs.). Dicionários na teoria e na prática: como e para quem são feitos. São Paulo, Editora Parábola, 2011.

XATARA, C; ZAVAGLIA, C; SILVA, R. M. Dicionário multilíngue de regência verbal: verbos preposicionados / XATARA, C; ZAVAGLIA, C; SILVA, R. M. (orgs). Barueri, São Paulo. Editora DISAL, 2013.

ZGUSTA, Ladislav. Manual of Lexicography. The Hague / Paris: Mouton, 1971.

\section{REFERÊNCIA DE DICIONÁRIOS}

AULETE, C. Dicionário Digital. Francisco J. Caldas Aulete/ Antonio Lopes dos Santos Valente. Editora Lexikon Digital, 2014. Disponível em: http://www.aulete.com.br/

BLUTEAU, Raphael. Vocabulario portuguez \& latino: aulico, anatomico, architectonico ... Coimbra: Collegio das Artes da Companhia de Jesu, 1712 - 1728. 8 v. Disponível em: https://archive.org/details/RaphaelBluteauVocabulPortuguezLatinoLetraA

BORBA, F. da S. Dicionário de usos do Português do Brasil. Editora Ática. São Paulo, 2002.

CAMBRIDGE UNIVERSITY PRESS. Cambridge learner's dictionaty. Second edition, Cambridge - UK, 2004. 
FERREIRA, A. B. de H. Novo Dicionário Eletrônico Aurélio versão 6.0. Editora Positivo, $4^{\text {a }}$ edição. Curitiba, 2009.

HOUAISS, Instituto Antônio. Dicionário Houaiss da língua portuguesa. Editora Objetiva. Rio de Janeiro, 2009.

LAROUSSE BRASIL. Dicionário Larousse inglês-português: essencial/ coordenação editorial José A. Gálvez. 2ª Edição, Larousse do Brasil. São Paulo, 2009.

MICHAELIS. Michaelis: dicionário prático inglês - português. Editora Melhoramento. São Paulo, 2010.

PALAVRA-CHAVE. Dicionário semibilíngue para brasileiros: francês/ [organização da Editora; traduzido por André Stahel M. da Silva] Editora WMF Matins Fontes. São Paulo, 2011.

PASSWORD: K DICTIONARIES. English dictionary for speakers of portuguesel [translated and edited by John Parker and Monica Stahel]. $4^{a}$ Edição. Editora Martins Fontes. São Paulo, 2010.

SEÑAS: dicionário para la enseñanza de la lengua española para basileños/ Universidade de Alacalá de Hernares. Departamento de Filologia; tradução de Eduardo Brandão, Claudia Berliner. 2a Edição, Martins Fontes, 2006.

XATARA, Cláudia; ZAVAGLIA, Cláudia; SILVA, Rosa Maria. Dicionário multilíngue de regência verbal: verbos preposicionados. Editora DISAL. Barueri - SP, 2013. 


\section{Anexo 1 - Lista de verbos identificados durante a pesquisa}

\begin{tabular}{|c|c|c|c|c|}
\hline & & 37) Adotar & 74) & Ameaçar \\
\hline 1) & Abastecer & 38) Adquirir & 75) & Ampliar \\
\hline 2) & Abater & 39) Adubar & 76) & Analisar \\
\hline 3) & Abordar & 40) Advogar & 77) & Andar \\
\hline 4) & Abrigar & 41) Afagar & 78) & Angariar \\
\hline 5) & Abrir & 42) Afastar & 79) & Animar \\
\hline 6) & Abusar & 43) Afetar & 80) & Anoitecer \\
\hline 7) & Acabar & 44) Afinar & 81) & Anotar \\
\hline 8) & Acalmar & 45) Afirmar & 82) & Antecipar \\
\hline 9) & Acarretar & 46) Agarrar & 83) & Anunciar \\
\hline 10) & Acatar & 47) Agendar & 84) & Apagar \\
\hline 11) & Acertar & 48) Agir & $85)$ & Apanhar \\
\hline 12) & Acessar & 49) Aglomerar & 86) & Aparecer \\
\hline 13) & Achar & 50) Agradar & 87) & Aparentar \\
\hline 14) & Acionar & 51) Agradecer & 88) & Apegar \\
\hline 15) & Aclamar & 52) Agravar & 89) & Apertar \\
\hline 16) & Acolher & 53) Agredir & 90) & Aplacar \\
\hline 17) & Acomodar & 54) Agregar & 91) & Aplicar \\
\hline 18) & Acompanhar & 55) Agrupar & 92) & Apoiar \\
\hline 19) & Aconselhar & 56) Aguardar & 93) & Apontar \\
\hline 20) & Acontecer & 57) Ajudar & 94) & Apostar \\
\hline 21) & Acordar & 58) Alarmar & 95) & Apreciar \\
\hline 22) & Acostumar & 59) Alastrar & 96) & Aprender \\
\hline 23) & Acreditar & 60) Alcançar & 97) & Apresentar \\
\hline 24) & Acrescentar & 61) Alegrar & 98) & Aprimorar \\
\hline 25) & Acrescer & 62) Alertar & 99) & Aproveitar \\
\hline 26) & Açucarar & 63) Alfabetizar & 100 & )) Aproximar \\
\hline 27) & Acumular & 64) Alimentar & 101 & ) Aprumar \\
\hline 28) & Adaptar & 65) Alinhar & 102 & 2) Apurar \\
\hline 29) & Adequar & 66) Almoçar & 103 & 3) Aquecer \\
\hline 30) & Aderir & 67) Alongar & 104 & 1) Arar \\
\hline 31) & Adiantar & 68) Alternar & 105 & ) Arejar \\
\hline 32) & Adicionar & 69) Alugar & 106 & 6) Argumentar \\
\hline 33) & Adivinhar & 70) Amadurecer & 107 & 7) Armazenar \\
\hline 34) & Administrar & 71) Amamentar & 108 & ) Arrebatar \\
\hline 35) & Adoçar & 72) Amanhecer & 109 & ) Arrematar \\
\hline 36) & Adorar & 73) Amar & 110 & ) Arriscar \\
\hline
\end{tabular}


111) Assar

112) Assegurar

113) Assinar

114) Assistir

115) Assumir

116) Assustar

117) Atacar

118) Atar

119) Atear

120) Atender

121) Atestar

122) Atingir

123) Atrair

124) Atrapalhar

125) Atrasar

126) Atropelar

127) Atualizar

128) Atuar

129) Aumentar

130) Autorizar

131) Auxiliar

132) Avaliar

133) Avançar

134) Averiguar

135) Avisar

136) Baixar

137) Bater

138) Batizar

139) Beber

140) Beliscar

141) Beneficiar

142) Boicotar

143) Brigar

144) Brincar

145) Buscar

146) Caber

147) Cadastrar

148) Cagar

149) Cair

150) Caminhar
151) Camuflar

152) Cancelar

153) Cantar

154) Capotar

155) Caprichar

156) Captar

157) Carregar

158) Casar

159) Causar

160) Cavar

161) Ceder

162) Celebrar

163) Cercar

164) Cesar

165) Chamar

166) Chegar

167) Chorar

168) Chover

169) Chutar

170) Circular

171) Citar

172) Clamar

173) Classificar

174) Coar

175) Cobrar

176) Cobrir

177) Colar

178) Colocar

179) Comandar

180) Combater

181) Combinar

182) Começar

183) Comemorar

184) Comentar

185) Comer

186) Comercializar

187) Comparar

188) Comparecer

189) Compartilhar

190) Compensar
191) Competir

192) Complementar

193) Completar

194) Compor

195) Comprar

196) Compreender

197) Comprometer

198) Comprovar

199) Comtemplar

200) Comunicar

201) Conceber

202) Conceder

203) Concentrar

204) Conciliar

205) Concluir

206) Concordar

207) Concorrer

208) Concretizar

209) Condenar

210) Conectar

211) Conferir

212) Confessar

213) Confiar

214) Confirmar

215) Confundir

216) Conhecer

217) Conquistar

218) Consagrar

219) Conscientizar

220) Conseguir

221) Conservar

222) Conservar

223) Considerar

224) Consolidar

225) Constar

226) Constatar

227) Construir

228) Consultar

229) Consumir

230) Contar 
231) Contemplar

232) Conter

233) Continuar

234) Contrair

235) Contrastar

236) Contribuir

237) Controlar

238) Convencer

239) Conversar

240) Convidar

241) Conviver

242) Coordenar

243) Copiar

244) Correr

245) Corrigir

246) Corroborar

247) Corromper

248) Cortar

249) Costumar

250) Cozer

251) Cozinhar

252) Crer

253) Crescer

254) Criar

255) Cruzar

256) Cuidar

257) Culminar

258) Cultivar

259) Cumprir

260) Cursar

261) Curtir

262) Custar

263) Dançar

264) Dar

265) Debater

266) Debutar

267) Decidir

268) Declarar

269) Decompor

270) Decorar
271) Decorrer

272) Decretar

273) Dedicar

274) Defender

275) Definir

276) Defumar

277) Degustar

278) Deixar

279) Delegar

280) Demandar

281) Demitir

282) Demonstrar

283) Demorar

284) Denunciar

285) Deparar

286) Depender

287) Depor

288) Deportar

289) Derrubar

290) Desabafar

291) Desanimar

292) Descansar

293) Descarregar

294) Descartar

295) Descer

296) Descobrir

297) Desconfiar

298) Desconhecer

299) Descrever

300) Descuidar

301) Desculpar

302) Desejar

303) Desembarcar

304) Desembolsar

305) Desempenhar

306) Desencadear

307) Desencontrar

308) Desenhar

309) Desenvolver

310) Desesperar
311) Desfazer

312) Desfilar

313) Desfrutar

314) Desgastar

315) Desistir

316) Desligar

317) Desmanchar

318) Desovar

319) Despedaçar

320) Despejar

321) Despertar

322) Desprender

323) Desregular

324) Dessalgar

325) Destacar

326) Destruir

327) Desvendar

328) Detectar

329) Determinar

330) Dever

331) Devolver

332) Diagnosticar

333) Dialogar

334) Diferenciar

335) Dificultar

336) Digerir

337) Digitar

338) Diminuir

339) Dirigir

340) Discursar

341) Discutir

342) Dispensar

343) Dispor

344) Disputar

345) Distinguir

346) Distribuir

347) Divagar

348) Divertir

349) Dividir

350) Divorciar 


351) Divulgar
352) Dizer
353) Dobrar
354) Dominar
355) Dormir
356) Driblar
357) Durar
358) Economizar
359) Educar
360) Elaborar
361) Eleger
362) Elevar
363) Elogiar
364) Embalar
365) Embarcar
366) Embutir
367) Emitir
368) Emocionar
369) Empacotar
370) Empanar
371) Empatar
372) Emplacar
373) Empolgar
374) Empregar
375) Empurrar
376) Encaminhar
377) Encantar
378) Encarregar
379) Encerar
380) Encerrar
381) Encher
382) Encontrar
383) Encurralar
384) Endividar
385) Enfeitar
386) Enfraquecer
387) Engarrafar
388) Englobar
389) Engolir
390) Engordar
36ra

351) Divulgar

352) Dizer

353) Dobrar

354) Dominar

Dormir

356) Driblar

7) Dura

359) Educar

360) Elaborar

362) Elevar

Elogiar

364) Embalar

365) Embarcar

367) Emitir

Emociona

370) Empanar

371) Empata

372) Emplacar

Empolga

375) Empurrar

377) Encantar

378) Encarregar

380) Encerrar

381) Encher

383) Encurralar

384) Endivida

385) Enfeitar

386) Enfraquecer

Engordar
391) Engravidar

392) Enriquecer

393) Enrolar

394) Ensacar

395) Ensaiar

396) Ensopar

397) Entender

398) Enterrar

399) Entrar

400) Entregar

401) Entreter

402) Entrevistar

403) Entupir

404) Envelhecer

405) Enviar

406) Envidraçar

407) Envolver

408) Enxergar

409) Enxugar

410) Equilibrar

411) Erguer

412) Errar

413) Esbaldar

414) Esbanjar

415) Escalar

416) Escapar

417) Esclarecer

418) Escolher

419) Escoltar

420) Esconder

421) Escorrer

422) Escrever

423) Esmerar

424) Espalhar

425) Especular

426) Espelhar

427) Esperar

428) Esquecer

429) Esquentar

430) Estabelecer
431) Estacionar

432) Estampar

433) Estar

434) Estender

435) Estimar

436) Estimular

437) Estourar

438) Estrear

439) Estreitar

440) Estressar

441) Estudar

442) Esvaecer

443) Esvaziar

444) Evitar

445) Evoluir

446) Exagerar

447) Excluir

448) Executar

449) Exemplificar

450) Exercer

451) Exercitar

452) Exibir

453) Exigir

454) Existir

455) Expandir

456) Experimentar

457) Explicar

458) Expor

459) Exportar

460) Expressar

461) Expulsar

462) Exterminar

463) Extrair

464) Fabricar

465) Facilitar

466) Falar

467) Faltar

468) Favorecer

469) Fazer

470) Fechar 


471) Ferir
472) Fervilhar
473) Ficar
474) Fidelizar
475) Figurar
476) Filtrar
477) Finalizar
478) Financiar
479) Firmar
480) Fiscalizar
481) Fixar
482) Flagrar
483) Flambar
484) Flertar
485) Focar
486) Foder
487) Forçar
488) Formar
489) Formatar
490) Fornecer
491) Forrar
492) Fotografar
493) Frequentar
494) Fritar
495) Frustrar
496) Frutificar
497) Fugir
498) Fumar
499) Funcionar
500) Fundar
501) Furar
502) Furtar
503) Ganhar
504) Garantir
505) Gastar
506) Gelar
509) Gerar
510) Gostar
50iar
50

471) Ferir

473) Ficar

474) Fidelizar

5) Figur

477) Finalizar

478) Financiar

479) Firmar

481) Fixar

482) Flagrar

484) Flertar

485) Focar

487) Forçar

488) Form

490) Fornecer

491) Forrar

492) Fotografar

33) Frequentar

495) Frustrar

496) Futicar

498) Fumar

499) Funcionar

500) Fundar

501) Furar

503) Ganhar

504) Garantir

510) Gostar
511) Graduar

512) Grafar

513) Gratinar

514) Gravar

515) Grelhar

516) Gritar

517) Guardar

518) Guarnecer

519) Guerrear

520) Harmonizar

521) Haver

522) Herdar

523) Hidratar

524) Hospedar

525) Idealizar

526) Identificar

527) Ignorar

528) Imaginar

529) Impedir

530) Imperar

531) Implicar

532) Impor

533) Importar

534) Impressionar

535) Improvisar

536) Impulsionar

537) Inaugurar

538) Incentivar

539) Inchar

540) Incluir

541) Incorporar

542) Incrementar

543) Indicar

544) Influenciar

545) Informar

546) Ingerir

547) Iniciar

548) Injetar

549) Inovar

550) Insistir
551) Inspirar

552) Inundar

553) Instalar

554) Integrar

555) Inteirar

556) Intensificar

557) Interagir

558) Interditar

559) Interferir

560) Interromper

561) Introduzir

562) Inventar

563) Investigar

564) Investir

565) $\mathrm{Ir}$

566) Isolar

567) Jantar

568) Jogar

569) Juntar

570) Justificar

571) Lamentar

572) Lançar

573) Lavar

574) Lembrar

575) Ler

576) Levantar

577) Levar

578) Lidar

579) Liderar

580) Ligar

581) Limpar

582) Localizar

583) Locomover

584) Lotar

585) Lutar

586) Machucar

587) Mamar

588) Mandar

589) Manejar

590) Manifestar 


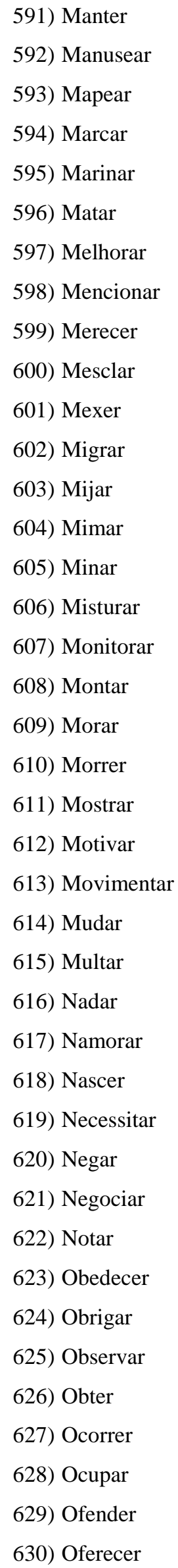

\begin{tabular}{|c|c|}
\hline 631) & Olhar \\
\hline 632) & Operar \\
\hline 633) & Opinar \\
\hline 634) & Optar \\
\hline 635$)$ & Organizar \\
\hline 636) & Orientar \\
\hline 637) & Originar \\
\hline 638) & Ousar \\
\hline 639) & Ouvir \\
\hline 640) & Pagar \\
\hline 641) & Paquerar \\
\hline 642) & Parar \\
\hline 643) & Parecer \\
\hline 644) & Parir \\
\hline 645) & Participar \\
\hline 646) & Partir \\
\hline 647) & Passar \\
\hline 648) & Passear \\
\hline 649) & Patrocinar \\
\hline 650$)$ & Pedalar \\
\hline 651) & Pedir \\
\hline 652) & Pegar \\
\hline 653) & Pensar \\
\hline 654) & Perceber \\
\hline 655$)$ & Percorrer \\
\hline 656) & Perder \\
\hline 657) & Perdoar \\
\hline 658) & Perguntar \\
\hline 659) & Permanecer \\
\hline 660) & Permitir \\
\hline 661) & Perseguir \\
\hline 662) & Pertencer \\
\hline 663) & Perturbar \\
\hline 664) & Pesar \\
\hline 665$)$ & Pesquisar \\
\hline 666) & Pintar \\
\hline 667) & Pipocar \\
\hline 668) & Planejar \\
\hline 669) & Plantar \\
\hline 670) & Poda \\
\hline
\end{tabular}

671) Poder

672) Pontuar

673) Pôr

674) Posar

675) Possuir

676) Postar

677) Poupar

678) Praticar

679) Precisar

680) Predominar

681) Preencher

682) Preferir

683) Prejudicar

684) Premiar

685) Prender

686) Prensar

687) Preocupar

688) Preparar

689) Prescrever

690) Preservar

691) Prestar

692) Pretender

693) Prevalecer

694) Prevenir

695) Prever

696) Prezar

697) Privar

698) Procurar

699) Produzir

700) Proferir

701) Projetar

702) Prometer

703) Promover

704) Propor

705) Proporcionar

706) Prosperar

707) Prosseguir

708) Proteger

709) Protestar

710) Protocolar 


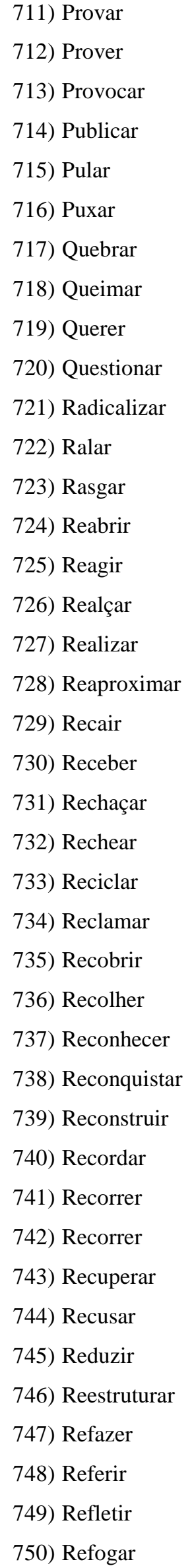

\begin{tabular}{|c|c|}
\hline 751) Reforçar & 791) Revezar \\
\hline 752) Reformar & 792) Revidar \\
\hline 753) Reformular & 793) Rir \\
\hline 754) Registrar & 794) Rodar \\
\hline 755) Regular & 795) Roer \\
\hline 756) Reinar & 796) Roubar \\
\hline 757) Rejeitar & 797) Saber \\
\hline 758) Relacionar & 798) Saborear \\
\hline 759) Relaxar & 799) Sabotar \\
\hline 760) Reluzir & 800) Saciar \\
\hline 761) Remar & 801) Sacrificar \\
\hline 762) Render & 802) Sair \\
\hline 763) Renovar & 803) Salvar \\
\hline 764) Reparar & 804) Satisfazer \\
\hline 765) Repassar & 805) Seguir \\
\hline 766) Repensar & 806) Segurar \\
\hline 767) Repetir & 807) Selecionar \\
\hline 768) Repor & 808) Sentar \\
\hline 769) Repousar & 809) Sentir \\
\hline 770) Representar & 810) Separar \\
\hline 771) Reproduzir & 811) Ser \\
\hline 772) Repudiar & 812) Servir \\
\hline 773) Requisitar & 813) Significar \\
\hline 774) Reservar & 814) Simular \\
\hline 775) Resguardar & 815) Sinalizar \\
\hline 776) Resistir & 816) Sobrecarregar \\
\hline 777) Resolver & 817) Sobreviver \\
\hline 778) Respeitar & 818) Sofrer \\
\hline 779) Respirar & 819) Solicitar \\
\hline 780) Responder & 820) Somar \\
\hline 781) Ressaltar & 821) Sonhar \\
\hline 782) Restringir & 822) Sorrir \\
\hline 783) Resultar & 823) Subir \\
\hline 784) Retirar & 824) Substituir \\
\hline 785) Retomar & 825) Subverter \\
\hline 786) Reunir & 826) Sugerir \\
\hline 787) Reutilizar & 827) Superar \\
\hline 788) Revelar & 828) Supor \\
\hline 789) Rever & 829) Suportar \\
\hline 790) Revestir & 830) Surfar \\
\hline
\end{tabular}




\begin{tabular}{|c|c|}
\hline 831) Surgir & 871) Ultrapassar \\
\hline 832) Surpreender & 872) Unir \\
\hline 833) Suspeitar & 873) Usar \\
\hline 834) Tabelar & 874) Usufruir \\
\hline 835) Teclar & 875) Utilizar \\
\hline 836) Teimar & 876) Vagar \\
\hline 837) Telefonar & 877) Valer \\
\hline 838) Temperar & 878) Valorizar \\
\hline 839) Tender & 879) Variar \\
\hline 840) Tentar & 880) Velejar \\
\hline 841) Ter & 881) Vencer \\
\hline 842) Terminar & 882) Vender \\
\hline 843) Testar & 883) Ver \\
\hline 844) Testemunhar & 884) Vestir \\
\hline 845) Tirar & 885) Viajar \\
\hline 846) Tocar & 886) Vincular \\
\hline 847) Tolerar & 887) Violar \\
\hline 848) Tomar & 888) Violentar \\
\hline 849) Tonificar & 889) Vir \\
\hline 850) Topar & 890) Virar \\
\hline 851) Torcer & 891) Visitar \\
\hline 852) Tornar & 892) Vistoriar \\
\hline 853) Torrar & 893) Viver \\
\hline 854) Tostar & 894) Voar \\
\hline 855) Trabalhar & 895) Voltar \\
\hline 856) Traduzir & 896) Votar \\
\hline 857) Trair & 897) Xerocar \\
\hline 858) Trançar & 898) Xingar \\
\hline \multicolumn{2}{|l|}{ 859) Transar } \\
\hline \multicolumn{2}{|l|}{ 860) Transbordar } \\
\hline \multicolumn{2}{|l|}{ 861) Transferir } \\
\hline \multicolumn{2}{|l|}{ 862) Transformar } \\
\hline \multicolumn{2}{|l|}{ 863) Transportar } \\
\hline \multicolumn{2}{|l|}{ 864) Tratar } \\
\hline \multicolumn{2}{|l|}{ 865) Trazer } \\
\hline \multicolumn{2}{|l|}{ 866) Treinar } \\
\hline \multicolumn{2}{|l|}{ 867) Trepar } \\
\hline \multicolumn{2}{|l|}{ 868) Trocar } \\
\hline 869) Tropeçar & \\
\hline 870) Trufar & \\
\hline
\end{tabular}




\section{Dicionário de aprendizagem de verbos do portug̉uês do Brasil como L2 Dicverb/PL2}

\section{Gulia de uso}

Este guia de uso oferece instruções a você de como consultar o Dicverb/PL2, está em português e, ao final desta página, em inglês. Assim, você poderá a explorar este dicionário de verbos utilizando apropriadamente as ferramentas que o Dicverb/PL2 oferece.

1. Apresentação da obra: serve para que você veja os objetivos e o público-alvo logo no primeiro contato com o Dicverb/PL2. Contém o número de entradas, as fontes de onde o corpus foi extraído, está em português e, após a apresentação em português, há a apresentação em inglês.

2. Lista de abreviaturas: indica as formas reduzidas da nomenclatura utilizada no dicionário, familiarizando você com a nomenclatura adotada na obra. O link Abreviaturas do Dicverb/PL2 aparece na parte superior.

3. Quadro fonético: indica o sistema fonético da língua portuguesa e foi incluído para oferecer a você o sistema dos sons da língua portuguesa. O quadro utiliza o International Phonetic Alphabet - IPA. Além do quadro fonético, há breve descrição sobre a fonética e a fonologia da língua portuguesa e um link para uma página, gratuita, desenvolvida pela equipe da Universidade Federal de Minas Gerais - UFMG, que oferece os sons das consoantes da língua portuguesa em http://www.fonologia.org/fonetica_consoantes.php e os sons das vogais da língua portuguesa em http://www.fonologia.org/fonetica_vogais.php .

4. Referência Bibliográfica: apresenta as referências bibliográficas e as fontes dos exemplos de uso utilizados na elaboração do Dicverb/PL2.

5. Recurso de busca: serve para que você localize o verbo no dicionário. Digite a palavra e clique em pesquisar. O recurso de busca de palavras sugere ou indica a forma correta da grafia de palavras e oferece a oportunidade para você aprender a ortografia das palavras.
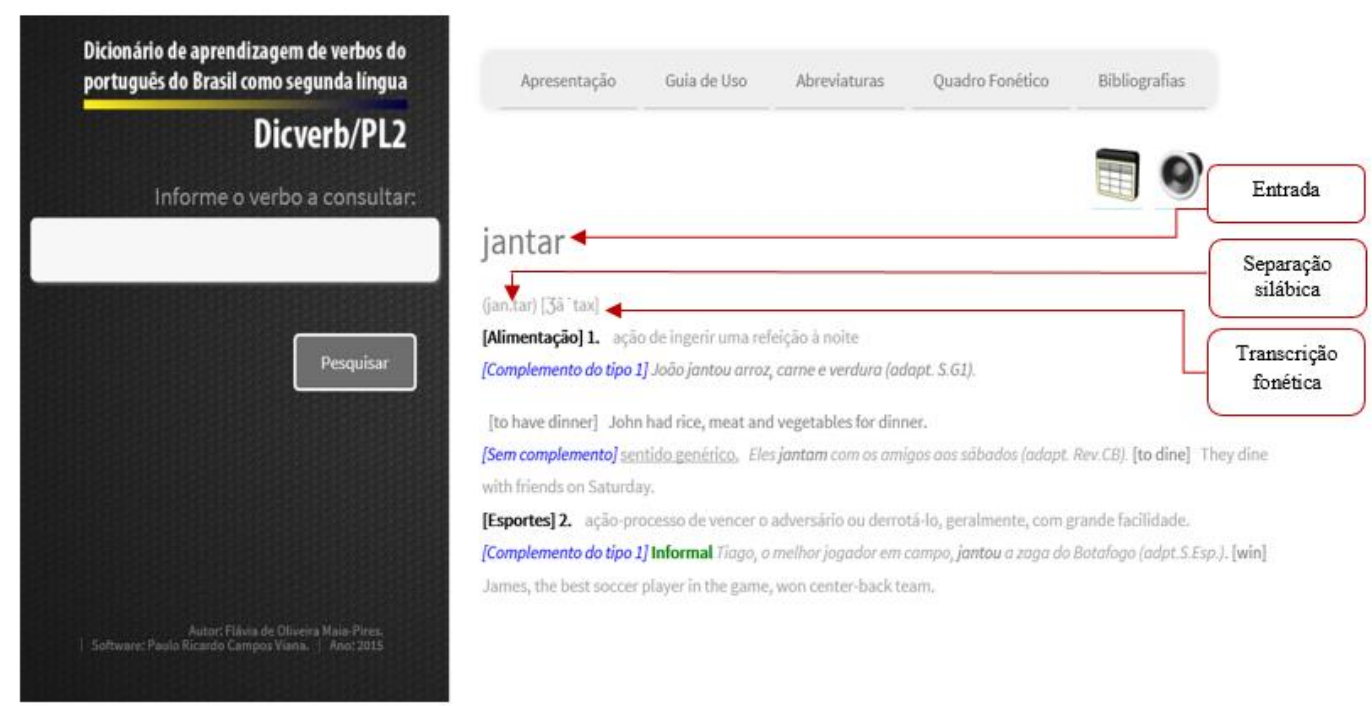

[Sem complemento] sentido generica, Eles jantam com os amigos oos sabbados (odapt Rev. CB). [to dine] They dine with friends on Saturday

[Esportes] 2.

[Complemento do tipo 1] Informal Tiago, o melhor jogador em campo, jantou a zoga do Botafogo (odpt S ESp.). [win]

James, the best soccer player in the game, won center back team. 
6. Entrada: indica a unidade linguística que possui conteúdo semântico e descreve o padrão ortográfico da língua. Está registrada em letras minúsculas, em negrito, em fonte maior que as outras palavras do verbete e na forma de lema, que é a forma não flexionada do verbo.

7. Divisão silábica: indica o padrão silábico da língua portuguesa, apresentada entre parênteses e separados por ponto ( . ). Este recurso fornece informações sobre as combinações dos grupos de fonemas possíveis na língua portuguesa e como são representados no sistema gráfico e auxilia você na percepção da posição do acento tônico e das regras de acentuação das palavras.

8. Transcrição fonética do verbo: indica o conjunto de sons e das combinações possíveis no português, o que permitirá a compreensão e a produção da fala, o que facilitará a aprendizagem da fonética e da fonologia; aparece entre colchetes [ ]. A transcrição baseia-se no sistema de notação fonética do Alfabeto Fonético Internacional, AFI (sigla em português), International Phonetic Alphabet, IPA (sigla em inglês) e nas informações fonéticas de Cristfaro-Silva (2009).

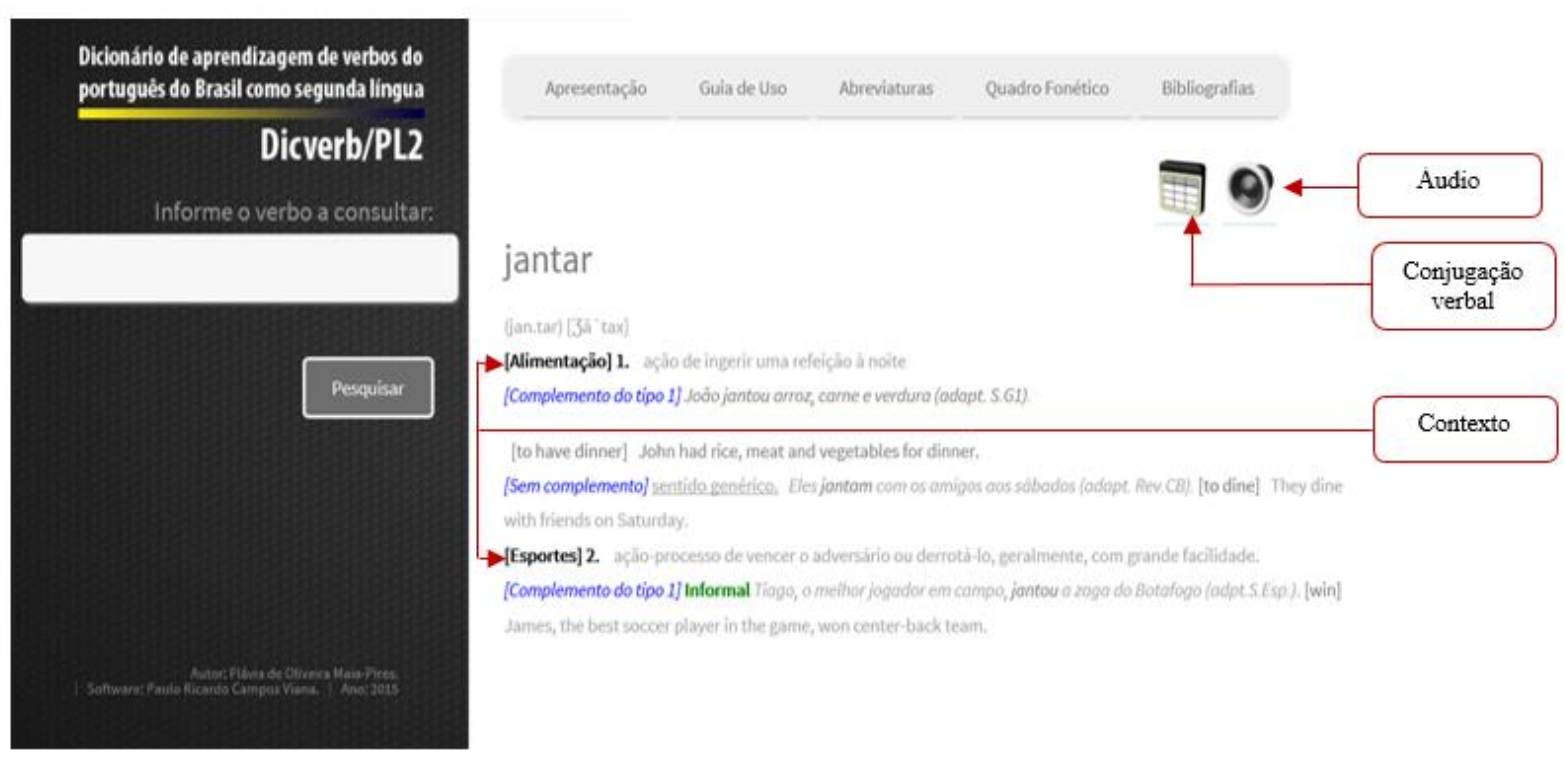

9. Áudio: reproduz a pronúncia do verbo para fornecer ao aprendiz um exemplo do falar de um brasileiro. A pronúncia que você ouvira é de um falante nativo da capital do país, Brasília.

10. Conjugação verbal: indica o processo morfológico dos verbos mediante conjugação que expressa tempo, modo, número e pessoa no discurso; foi destacada com o uso de recursos como cor, destaque em itálico e em negrito para visualização do aprendiz no quadro de conjugação verbal referente a cada verbo. A vogal temática dos verbos que os distinguem em $1^{\mathrm{a}}, 2^{\mathrm{a}}$ e $3^{\mathrm{a}}$ conjugação estão em itálico, como jantar, comer, abrir. O sufixo que indica modo e tempo está na cor vermelha e em negrito, como jantava, jantara, jantasse. A desinência que indica número-pessoa está apenas em vermelho, como jantavas, jantaste, jantávamos, jantamos. Foram mantidos na conjugação os modos e as pessoas do discurso que são de baixa frequência, como o pretérito mais-que-perfeito e a $2^{\mathrm{a}}$ pessoa do plural. 
Você tem a opção de imprimir a grade com as conjugações, ao clicar com o botão direito na tela de conjugação.

11. Contexto: indica informações extralinguísticas referentes às condições de produção do significado em que o item lexical é usado, fornece informações como tempo, espaço, participantes do evento comunicativo, organização social, normas de pensamento e comportamento da comunidade de fala, assim, essas informações delimitam o significado dos verbos; está em negrito, entre colchetes [ ] e se inicia com letra maiúscula. Uma vez delimitado o público-alvo do dicionário, o Dicverb/PL2 apresenta um vocabulário básico para atender à compreensão e à produção de textos sobre o cotidiano dos brasileiros, em torno dos seguintes contextos:

[Alimentar] Contextos relacionados à ação, ao estado ou ao processo de alimentar ou nutrir o corpo com substâncias digeríveis pelo organismo.

[Atividades comerciais] Contextos relacionados à ação, ao estado ou ao processo de atividades de troca, de venda ou de compra de bens, produtos, mercadorias e serviços.

[Atividades domésticas]Contextos relacionados à ação, ao estado ou ao processo que envolvem as atividades, a administração ou a organização do lar, da família, da vida particular de uma pessoa.

[Clima e tempo] Contextos relacionados à ação, ao estado ou ao processo que envolvem as condições atmosféricas que exercem influências sobre a vida na Terra, as características específicas das regiões e as condições meteorológicas.

[Crime e violência] Contextos relacionados à ação, ao estado ou ao processo que envolvem a transgressão moral ou ética, socialmente rejeitada, seja por ação, seja por omissão, empregando força física ou psicológica, passiva de punição pela lei penal.

[Educação] Contextos relacionados à ação, ao estado ou ao processo que envolvem desenvolvimento físico, intelectual, social e moral do ser humano, que assegure sua formação sócio-histórico-cultural, seja em ambiente familiar, seja em ambiente formal.

[Esporte] Contextos relacionados à ação, ao estado ou ao processo que envolvem as práticas, individuais ou coletivas, de jogos e de exercícios físicos, seja com fins de recreação, seja com fins de condicionamento corporal para benefício da saúde, seja para competições esportivas.

[Festas e festividades] Contextos relacionados à ação, ao estado ou ao processo que envolvem reuniões de pessoas com fins recreativos, enquadrando-se às festas familiares, às solenidades civis e às de caráter religioso.

[Lazer] Contextos relacionados ao tempo utilizado para o ócio, o descanso e outras atividades prazerosas.

[Moradia] Contexto relacionados à ação, ao estado ou ao processo de residir, habitar, viver em barraco, casa, apartamento, mansão ou outro lugar.

[Profissão e trabalho] Contextos relacionados à ação, ao estado ou ao processo que envolvem ofício, trabalho, ocupação, atividade profissional em que uma pessoa visa obter recursos financeiros, como remuneração ou salário. 
[Relações sociais] Contextos relacionados à ação, ao estado ou ao processo que envolvem o convívio entre pessoas ou grupo de pessoas com interesses comuns, que se relacionam com fins particulares, profissionais, familiares, emocionais, de acordo com a cultura e a sociedade local.

[Saúde e doenças] Contextos relacionados à ação, ao estado ou ao processo que envolvem as condições físicas e psíquicas, proporcionando o bem-estar, e quando não estão equilibradas, provocam enfermidades, mal, moléstia aos seres vivos, podendo apresentar sintomas.

[Tabuísmo] Contextos relacionados à ação, ao estado ou ao processo que envolvem comportamentos, palavras ou expressões consideradas chulas, grosseiras ou ofensivas em determinados contextos sociais.

[Trânsito e transporte]Contextos relacionados à ação, ao estado ou ao processo que envolve movimentação, trajeto, passagens ou deslocamento em determinado lugar, com utilização ou não de veículos.

[Vestimentas e indumentárias]Contextos relacionados à ação, ao estado ou ao processo que envolvem o hábito sociocultural de utilizar roupas e acessório para vestir o corpo ou partes do corpo.

[Viagem] Contextos relacionados à ação, ao estado ou ao processo que envolvem deslocamentos de um lugar para outro, relativamente distante, normalmente com finalidade profissional ou de entretenimento e turismo.
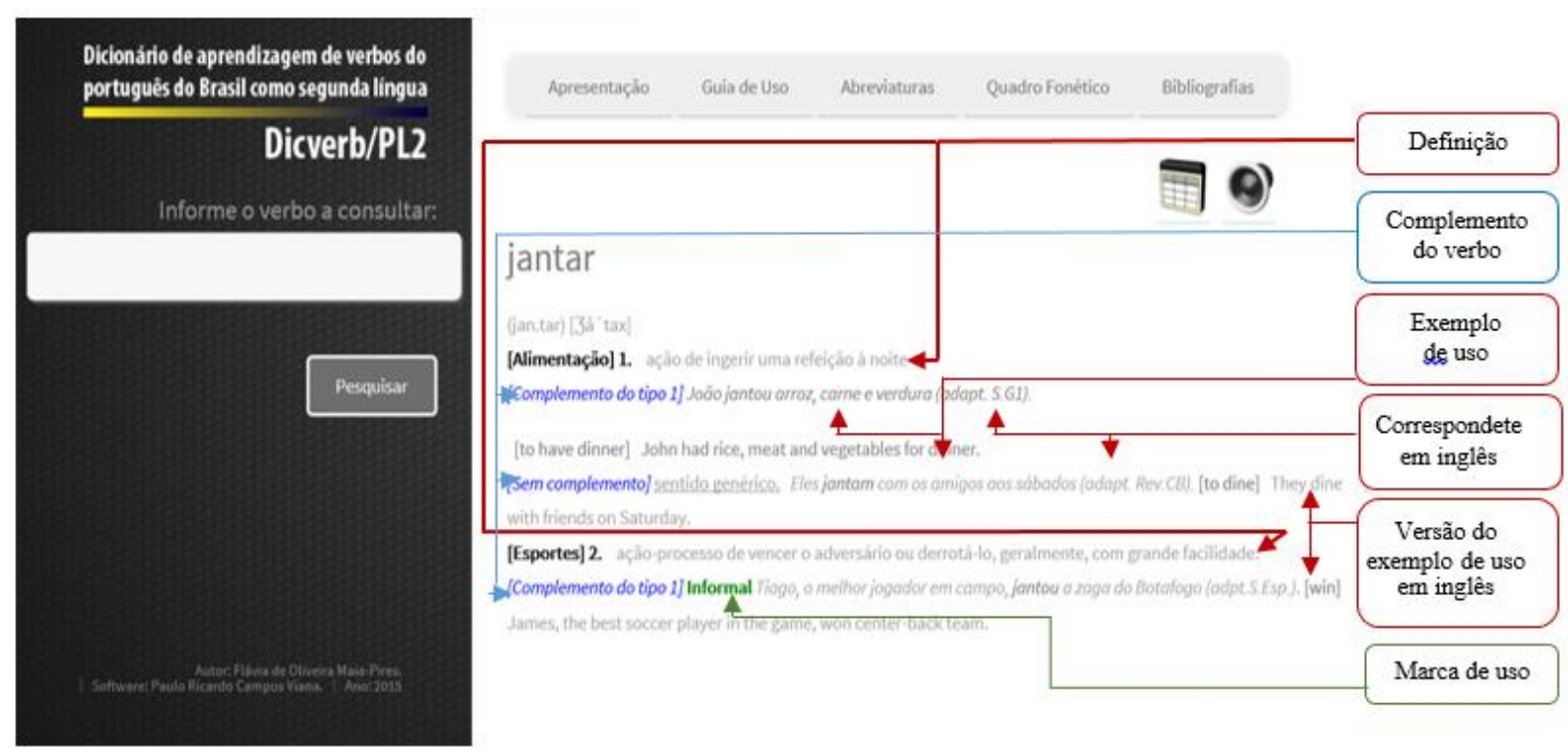

12. Definição: indica o(s) significados(s) pertinente(s) dos itens lexicais; está localizada após a indicação do contexto e é numerada. Serão descritas com base nas definições apresentadas no dicionário Borba (2002), no dicionário Houaiss (2009) e no dicionário Aulete digital (2014). As definições que não estiverem dentro dos temas selecionados serão eliminadas. As acepções são adaptadas para apresentar: tipo do verbo (estado, processo, ação ou ação-processo); significado do verbo; complementos que cooperam para o significado apresentado pelo verbo no contexto e preposição que liga o verbo ao seu complemento interno nos casos de $\mathrm{C} 2$ ou $\mathrm{C} 3$.

13. Complemento verbal: indica a relação entre o verbo e a exigência verbal para completar seu significado, quer dizer, a recusa e a aceitação livre dos complementos pelo verbo, em vista da especificação dos complementos verbais; está na cor azul e entre colchetes [ ]. "Implica a valência verbal, isto é, a capacidade de os verbos abrirem casas para preenchimento por termos (sujeito e 
complemento), compondo-se a estrutura argumental" (NEVES, 2000, p. 28). E na proposta do Dicverb/PL2, os tipos dos complementos verbais são apresentados de acordo com a associação dos significados correspondentes. Serão marcados apenas os complementos internos dos verbos do seguinte modo:

Sem complemento $=$ para verbos que não exigem complementos interno $-\mathrm{C} 0 ;$

Complemento 1 = complemento interno ligado ao verbo sem preposição $-\mathrm{C} 1$;

Complemento 2 = complemento interno ligado ao verbo por preposição $-\mathrm{C} 2 \mathrm{e}$

Complemento 3 = complemento interno ligado ao verbo por preposição $-\mathrm{C} 3$.

14. Exemplos de uso: indica o uso do item lexical no contexto de uso; está em itálico e a ocorrência do verbo está em itálico e em negrito. Os exemplos foram recolhidos para demonstrar o uso real dos verbos no cotidiano dos brasileiros, por isso foram selecionados de notícias divulgadas na internet, preferencialmente de sites de jornais ou de revistas de grande circulação, de sites especializados e de filmes brasileiros contemporâneos de grande bilheteria, de acordo com os 17 contextos abordados.

15. Correspondente em inglês: indica que a unidade lexical da L1 e L2 que se aproximam, do ponto de vista conceitual; estão entre colchetes [ ]. Foi registrado o item lexical correspondente na língua inglês de acordo com o significado relacionado ao contexto linguístico e ao contexto de uso do verbo em português.

16. Versões dos exemplos de uso: indica a versão do exemplo de uso do enunciado em inglês. A versão foi elaborada para transmitir o significado do enunciado ao aprendiz iniciante.

17. Marcas de uso: indica as variantes no espaço, no tempo ou no registro mais ou menos formal; está na cor verde. As marcas de uso obedecem às dicotomias formal e informal, ao uso nacional e uso regional, sendo os elementos marcados o informal e o regional. 


\section{Anexo 3 - conjugação dos verbos da amostragem}

\begin{tabular}{|c|c|c|c|c|c|c|c|c|c|}
\hline \multirow[b]{3}{*}{ Tempo } & \multicolumn{9}{|c|}{ Modo: Indicativo } \\
\hline & \multicolumn{3}{|c|}{ Singular } & \multicolumn{3}{|c|}{ Plural } & \multicolumn{3}{|c|}{ Informal } \\
\hline & $1^{a}$ & $2^{a}$ & $3^{\mathbf{a}}$ & $1^{\mathrm{a}}$ & $2^{a}$ & $3^{\mathbf{a}}$ & $\begin{array}{c}2^{\mathbf{a}} \\
\text { Singular }\end{array}$ & $\begin{array}{c}1^{a} \\
\text { Plural }\end{array}$ & $\begin{array}{c}2^{a} \\
\text { Plural }\end{array}$ \\
\hline Presente & $\begin{array}{l}\text { Eu } \\
\text { bebo }\end{array}$ & $\begin{array}{l}\text { Tu } \\
\text { bebes }\end{array}$ & $\begin{array}{l}\text { Ele } \\
\text { bebe }\end{array}$ & $\begin{array}{l}\text { Nós } \\
\text { bebemos }\end{array}$ & $\begin{array}{l}\text { Vós } \\
\text { bebeis }\end{array}$ & $\begin{array}{l}\text { Eles } \\
\text { bebem }\end{array}$ & $\begin{array}{l}\text { Você } \\
\text { bebe }\end{array}$ & $\begin{array}{l}\text { A gente } \\
\text { bebe }\end{array}$ & $\begin{array}{l}\text { Vocês } \\
\text { bebem }\end{array}$ \\
\hline $\begin{array}{l}\text { Pretérito } \\
\text { Imperfeito }\end{array}$ & $\begin{array}{l}\text { Eu } \\
\text { bebia }\end{array}$ & $\begin{array}{l}\text { Tu } \\
\text { bebias }\end{array}$ & $\begin{array}{l}\text { Ele } \\
\text { bebia }\end{array}$ & $\begin{array}{l}\text { Nós } \\
\text { bebíamos }\end{array}$ & $\begin{array}{l}\text { Vós } \\
\text { bebieis }\end{array}$ & $\begin{array}{l}\text { Eles } \\
\text { bebiam }\end{array}$ & $\begin{array}{l}\text { Você } \\
\text { bebia }\end{array}$ & $\begin{array}{l}\text { A gente } \\
\text { bebia }\end{array}$ & $\begin{array}{l}\text { Vocês } \\
\text { bebiam }\end{array}$ \\
\hline $\begin{array}{l}\text { Pretérito } \\
\text { Perfeito }\end{array}$ & $\begin{array}{l}\text { Eu } \\
\text { bebi }\end{array}$ & $\begin{array}{l}\text { Tu } \\
\text { bebeste }\end{array}$ & $\begin{array}{l}\text { Ele } \\
\text { bebeu }\end{array}$ & $\begin{array}{l}\text { Nós } \\
\text { bebemos }\end{array}$ & $\begin{array}{l}\text { Vós } \\
\text { bebestes }\end{array}$ & $\begin{array}{l}\text { Eles } \\
\text { beberam }\end{array}$ & $\begin{array}{l}\text { Você } \\
\text { bebeu }\end{array}$ & $\begin{array}{l}\text { A gente } \\
\text { bebeu }\end{array}$ & $\begin{array}{l}\text { Vocês } \\
\text { beberam }\end{array}$ \\
\hline $\begin{array}{l}\text { Pretérito } \\
\text { mais que } \\
\text { Perfeito }\end{array}$ & $\begin{array}{l}\text { Eu } \\
\text { bebera }\end{array}$ & $\begin{array}{l}\text { Tu } \\
\text { beberas }\end{array}$ & $\begin{array}{l}\text { Ele } \\
\text { bebera }\end{array}$ & $\begin{array}{l}\text { Nós } \\
\text { bebêramos }\end{array}$ & $\begin{array}{l}\text { Vós } \\
\text { bebêreis }\end{array}$ & $\begin{array}{l}\text { Eles } \\
\text { beberam }\end{array}$ & $\begin{array}{l}\text { Você } \\
\text { bebera }\end{array}$ & $\begin{array}{l}\text { A gente } \\
\text { bebera }\end{array}$ & $\begin{array}{l}\text { Vocês } \\
\text { beberam }\end{array}$ \\
\hline $\begin{array}{l}\text { Futuro do } \\
\text { Pretérito }\end{array}$ & $\begin{array}{l}\text { Eu } \\
\text { beberia }\end{array}$ & $\begin{array}{l}\text { Tu } \\
\text { beberias }\end{array}$ & $\begin{array}{l}\text { Ele } \\
\text { beberia }\end{array}$ & $\begin{array}{l}\text { Nós } \\
\text { beberiamos }\end{array}$ & $\begin{array}{l}\text { Vós } \\
\text { beberieis }\end{array}$ & $\begin{array}{l}\text { Eles } \\
\text { beberiam }\end{array}$ & $\begin{array}{l}\text { Você } \\
\text { beberia }\end{array}$ & $\begin{array}{l}\text { A gente } \\
\text { beberia }\end{array}$ & $\begin{array}{l}\text { Vocês } \\
\text { beberiam }\end{array}$ \\
\hline $\begin{array}{l}\text { Futuro do } \\
\text { Presente }\end{array}$ & $\begin{array}{l}\text { Eu } \\
\text { beberei }\end{array}$ & $\begin{array}{l}\text { Tu } \\
\text { beberás }\end{array}$ & $\begin{array}{l}\text { Ele } \\
\text { beberá }\end{array}$ & $\begin{array}{l}\text { Nós } \\
\text { beberemos }\end{array}$ & $\begin{array}{l}\text { Vós } \\
\text { bebereis }\end{array}$ & $\begin{array}{l}\text { Eles } \\
\text { beberão }\end{array}$ & $\begin{array}{l}\text { Você } \\
\text { beberá }\end{array}$ & $\begin{array}{l}\text { A gente } \\
\text { beberá }\end{array}$ & $\begin{array}{l}\text { Vocês } \\
\text { beberão }\end{array}$ \\
\hline
\end{tabular}

\begin{tabular}{|c|c|c|c|c|c|c|c|c|c|}
\hline \multirow[b]{3}{*}{ Tempo } & \multicolumn{9}{|c|}{ Modo: Subjuntivo } \\
\hline & \multicolumn{3}{|c|}{ Singular } & \multicolumn{3}{|c|}{ Plural } & \multicolumn{3}{|c|}{ Informal } \\
\hline & $1^{a}$ & $2^{a}$ & $3^{\mathbf{a}}$ & $1^{a}$ & $2^{a}$ & $3^{a}$ & $\begin{array}{c}\mathbf{2}^{\mathbf{a}} \\
\text { Singular }\end{array}$ & $\begin{array}{c}1^{a} \\
\text { Plural }\end{array}$ & $\begin{array}{c}2^{\mathrm{a}} \\
\text { Plural }\end{array}$ \\
\hline Presente & $\begin{array}{l}\text { Eu } \\
\text { beba }\end{array}$ & $\begin{array}{l}\text { Tu } \\
\text { bebas }\end{array}$ & Ele beba & $\begin{array}{l}\text { Nós } \\
\text { bebamos }\end{array}$ & $\begin{array}{l}\text { Vós } \\
\text { bebais }\end{array}$ & $\begin{array}{l}\text { Eles } \\
\text { bebam }\end{array}$ & $\begin{array}{l}\text { Você } \\
\text { beba }\end{array}$ & $\begin{array}{l}\text { A gente } \\
\text { beba }\end{array}$ & $\begin{array}{l}\text { Vocês } \\
\text { bebam }\end{array}$ \\
\hline Pretérito & $\begin{array}{l}\text { Eu } \\
\text { bebesse }\end{array}$ & $\begin{array}{l}\text { Tu } \\
\text { bebesses }\end{array}$ & $\begin{array}{l}\text { Ele } \\
\text { bebesse }\end{array}$ & $\begin{array}{l}\text { Nós } \\
\text { bebêssemos }\end{array}$ & $\begin{array}{l}\text { Vós } \\
\text { bebêsseis }\end{array}$ & $\begin{array}{l}\text { Eles } \\
\text { bebessem }\end{array}$ & $\begin{array}{l}\text { Você } \\
\text { bebesse }\end{array}$ & $\begin{array}{l}\text { A gente } \\
\text { bebesse }\end{array}$ & $\begin{array}{l}\text { Vocês } \\
\text { bebessem }\end{array}$ \\
\hline Futuro & $\begin{array}{l}\text { Eu } \\
\text { beber }\end{array}$ & $\begin{array}{l}\text { Tu } \\
\text { beberes }\end{array}$ & $\begin{array}{l}\text { Ele } \\
\text { beber }\end{array}$ & $\begin{array}{l}\text { Nós } \\
\text { bebermos }\end{array}$ & $\begin{array}{l}\text { Vós } \\
\text { beberdes }\end{array}$ & $\begin{array}{l}\text { Eles } \\
\text { beberem }\end{array}$ & $\begin{array}{l}\text { Você } \\
\text { beber }\end{array}$ & $\begin{array}{l}\text { A gente } \\
\text { beber }\end{array}$ & $\begin{array}{l}\text { Vocês } \\
\text { beberem }\end{array}$ \\
\hline
\end{tabular}




\begin{tabular}{|c|c|c|c|c|c|c|c|c|c|}
\hline & \multicolumn{9}{|c|}{ Modo: Imperativo } \\
\hline & \multicolumn{3}{|c|}{ Singular } & \multicolumn{3}{|c|}{ Plural } & \multicolumn{3}{|c|}{ Informal } \\
\hline & $1^{2}$ & $2^{a}$ & $3^{a}$ & $1^{a}$ & $2^{\mathrm{a}}$ & $3^{a}$ & $\begin{array}{c}2^{\mathrm{a}} \\
\text { Singular }\end{array}$ & $\begin{array}{c}1^{\mathrm{a}} \\
\text { Plural }\end{array}$ & $\begin{array}{c}2^{\mathrm{a}} \\
\text { Plural }\end{array}$ \\
\hline Afirmativo & - & Tu bebe & $\begin{array}{l}\text { Ele } \\
\text { beba }\end{array}$ & $\begin{array}{l}\text { Nós } \\
\text { bebamos }\end{array}$ & $\begin{array}{l}\text { Vós } \\
\text { bebei }\end{array}$ & $\begin{array}{l}\text { Eles } \\
\text { bebam }\end{array}$ & Você beba & $\begin{array}{l}\text { A gente } \\
\text { beba }\end{array}$ & $\begin{array}{l}\text { Vocês } \\
\text { bebam }\end{array}$ \\
\hline Negativo & 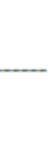 & $\begin{array}{l}\text { Não } \\
\text { bebas tu }\end{array}$ & $\begin{array}{l}\text { Não } \\
\text { beba } \\
\text { ele }\end{array}$ & $\begin{array}{l}\text { Não } \\
\text { bebamos } \\
\text { nós }\end{array}$ & $\begin{array}{l}\text { Não } \\
\text { bebais } \\
\text { vós }\end{array}$ & $\begin{array}{l}\text { Não } \\
\text { bebam } \\
\text { eles }\end{array}$ & $\begin{array}{l}\text { Não beba } \\
\text { você }\end{array}$ & $\begin{array}{l}\text { Não } \\
\text { beba a } \\
\text { gente }\end{array}$ & $\begin{array}{l}\text { Não } \\
\text { bebam } \\
\text { vocês }\end{array}$ \\
\hline
\end{tabular}

\begin{tabular}{|c|c|c|c|c|c|c|c|c|c|}
\hline \multirow[b]{3}{*}{ Tempo } & \multicolumn{9}{|c|}{ Modo: Indicativo } \\
\hline & \multicolumn{3}{|c|}{ Singular } & \multicolumn{3}{|c|}{ Plural } & \multicolumn{3}{|c|}{ Informal } \\
\hline & $1^{2}$ & $2^{\mathrm{a}}$ & $3^{a}$ & $1^{3}$ & $2^{3}$ & $3^{3}$ & $\begin{array}{c}2^{\mathbf{a}} \\
\text { Singular }\end{array}$ & $\begin{array}{c}1^{a} \\
\text { Plural }\end{array}$ & $\begin{array}{c}2^{\mathrm{a}} \\
\text { Plural }\end{array}$ \\
\hline Presente & Eu como & $\begin{array}{l}\text { Tu } \\
\text { comes }\end{array}$ & $\begin{array}{l}\text { Ele } \\
\text { come }\end{array}$ & $\begin{array}{l}\text { Nós } \\
\text { comemos }\end{array}$ & $\begin{array}{l}\text { Vós } \\
\text { comeis }\end{array}$ & $\begin{array}{l}\text { Eles } \\
\text { comem }\end{array}$ & $\begin{array}{l}\text { Você } \\
\text { come }\end{array}$ & $\begin{array}{l}\text { A gente } \\
\text { come }\end{array}$ & $\begin{array}{l}\text { Vocês } \\
\text { comem }\end{array}$ \\
\hline $\begin{array}{l}\text { Pretérito } \\
\text { Imperfeito }\end{array}$ & $\begin{array}{l}\text { Eu } \\
\text { comia }\end{array}$ & $\begin{array}{l}\text { Tu } \\
\text { comias }\end{array}$ & $\begin{array}{l}\text { Ele } \\
\text { comia }\end{array}$ & $\begin{array}{l}\text { Nós } \\
\text { comíamos }\end{array}$ & $\begin{array}{l}\text { Vós } \\
\text { comíeis }\end{array}$ & $\begin{array}{l}\text { Eles } \\
\text { comiam }\end{array}$ & $\begin{array}{l}\text { Você } \\
\text { comia }\end{array}$ & $\begin{array}{l}\text { A gente } \\
\text { comia }\end{array}$ & $\begin{array}{l}\text { Vocês } \\
\text { comiam }\end{array}$ \\
\hline $\begin{array}{l}\text { Pretérito } \\
\text { Perfeito }\end{array}$ & $\begin{array}{l}\mathrm{Eu} \\
\text { comi }\end{array}$ & $\begin{array}{l}\text { Tu } \\
\text { comeste }\end{array}$ & $\begin{array}{l}\text { Ele } \\
\text { comeu }\end{array}$ & $\begin{array}{l}\text { Nós } \\
\text { comemos }\end{array}$ & $\begin{array}{l}\text { Vós } \\
\text { comestes }\end{array}$ & $\begin{array}{l}\text { Eles } \\
\text { comeram }\end{array}$ & $\begin{array}{l}\text { Você } \\
\text { comeu }\end{array}$ & $\begin{array}{l}\text { A gente } \\
\text { comeu }\end{array}$ & $\begin{array}{l}\text { Vocês } \\
\text { comeram }\end{array}$ \\
\hline $\begin{array}{l}\text { Pretérito } \\
\text { mais que } \\
\text { Perfeito }\end{array}$ & $\begin{array}{l}\text { Eu } \\
\text { comera }\end{array}$ & $\begin{array}{l}\text { Tu } \\
\text { comeras }\end{array}$ & $\begin{array}{l}\text { Ele } \\
\text { comera }\end{array}$ & $\begin{array}{l}\text { Nós } \\
\text { comêramos }\end{array}$ & $\begin{array}{l}\text { Vós } \\
\text { comêreis }\end{array}$ & $\begin{array}{l}\text { Eles } \\
\text { comeram }\end{array}$ & $\begin{array}{l}\text { Você } \\
\text { comera }\end{array}$ & $\begin{array}{l}\text { A gente } \\
\text { comera }\end{array}$ & $\begin{array}{l}\text { Vocês } \\
\text { comeram }\end{array}$ \\
\hline $\begin{array}{l}\text { Futuro do } \\
\text { Pretérito }\end{array}$ & $\begin{array}{l}\text { Eu } \\
\text { comeria }\end{array}$ & $\begin{array}{l}\text { Tu } \\
\text { comerias }\end{array}$ & $\begin{array}{l}\text { Ele } \\
\text { comeria }\end{array}$ & $\begin{array}{l}\text { Nós } \\
\text { comeríamos }\end{array}$ & $\begin{array}{l}\text { Vós } \\
\text { comeríeis }\end{array}$ & $\begin{array}{l}\text { Eles } \\
\text { comeriam }\end{array}$ & $\begin{array}{l}\text { Você } \\
\text { comeria }\end{array}$ & $\begin{array}{l}\text { A gente } \\
\text { comeria }\end{array}$ & $\begin{array}{l}\text { Vocês } \\
\text { comeriam }\end{array}$ \\
\hline $\begin{array}{l}\text { Futuro do } \\
\text { Presente }\end{array}$ & $\begin{array}{l}\text { Eu } \\
\text { comerei }\end{array}$ & $\begin{array}{l}\text { Tu } \\
\text { comerás }\end{array}$ & $\begin{array}{l}\text { Ele } \\
\text { comerá }\end{array}$ & $\begin{array}{l}\text { Nós } \\
\text { comeremos }\end{array}$ & $\begin{array}{l}\text { Vós } \\
\text { comereis }\end{array}$ & $\begin{array}{l}\text { Eles } \\
\text { comerão }\end{array}$ & $\begin{array}{l}\text { Você } \\
\text { comerá }\end{array}$ & $\begin{array}{l}\text { A gente } \\
\text { comerá }\end{array}$ & $\begin{array}{l}\text { Vocês } \\
\text { comerão }\end{array}$ \\
\hline
\end{tabular}




\begin{tabular}{|c|c|c|c|c|c|c|c|c|c|}
\hline \multirow[b]{3}{*}{ Tempo } & \multicolumn{9}{|c|}{ Modo: Subjuntivo } \\
\hline & \multicolumn{3}{|c|}{ Singular } & \multicolumn{3}{|c|}{ Plural } & \multicolumn{3}{|c|}{ Informal } \\
\hline & $1^{a}$ & $2^{a}$ & $3^{\mathbf{a}}$ & $1^{a}$ & $2^{a}$ & $3^{a}$ & $\begin{array}{c}2^{\mathrm{a}} \\
\text { Singular }\end{array}$ & $\begin{array}{c}1^{a} \\
\text { Plural }\end{array}$ & $\begin{array}{c}2^{a} \\
\text { Plural }\end{array}$ \\
\hline Presente & $\begin{array}{l}\text { Eu } \\
\text { coma }\end{array}$ & $\begin{array}{l}\text { Tu } \\
\text { comas }\end{array}$ & Ele coma & $\begin{array}{l}\text { Nós } \\
\text { comamos }\end{array}$ & $\begin{array}{l}\text { Vós } \\
\text { comais }\end{array}$ & $\begin{array}{l}\text { Eles } \\
\text { comam }\end{array}$ & $\begin{array}{l}\text { Você } \\
\text { coma }\end{array}$ & $\begin{array}{l}\text { A gente } \\
\text { coma }\end{array}$ & $\begin{array}{l}\text { Vocês } \\
\text { comam }\end{array}$ \\
\hline Pretérito & $\begin{array}{l}\text { Eu } \\
\text { comesse }\end{array}$ & $\begin{array}{l}\text { Tu } \\
\text { comesses }\end{array}$ & $\begin{array}{l}\text { Ele } \\
\text { comesse }\end{array}$ & $\begin{array}{l}\text { Nós } \\
\text { comêssemos }\end{array}$ & $\begin{array}{l}\text { Vós } \\
\text { comêsseis }\end{array}$ & $\begin{array}{l}\text { Eles } \\
\text { comessem }\end{array}$ & $\begin{array}{l}\text { Você } \\
\text { comesse }\end{array}$ & $\begin{array}{l}\text { A gente } \\
\text { comesse }\end{array}$ & $\begin{array}{l}\text { Vocês } \\
\text { comessem }\end{array}$ \\
\hline Futuro & $\begin{array}{l}\text { Eu } \\
\text { comer }\end{array}$ & $\begin{array}{l}\text { Tu } \\
\text { comeres }\end{array}$ & $\begin{array}{l}\text { Ele } \\
\text { comer }\end{array}$ & $\begin{array}{l}\text { Nós } \\
\text { comermos }\end{array}$ & $\begin{array}{l}\text { Vós } \\
\text { comerdes }\end{array}$ & $\begin{array}{l}\text { Eles } \\
\text { comerem }\end{array}$ & $\begin{array}{l}\text { Você } \\
\text { comer }\end{array}$ & $\begin{array}{l}\text { A gente } \\
\text { comer }\end{array}$ & $\begin{array}{l}\text { Vocês } \\
\text { comerem }\end{array}$ \\
\hline
\end{tabular}

\begin{tabular}{|c|c|c|c|c|c|c|c|c|c|}
\hline & \multicolumn{9}{|c|}{ Modo: Imperativo } \\
\hline & \multicolumn{3}{|c|}{ Singular } & \multicolumn{3}{|c|}{ Plural } & \multicolumn{3}{|c|}{ Informal } \\
\hline & $1^{2}$ & $2^{\mathrm{a}}$ & $3^{a}$ & $1^{a}$ & $2^{\mathrm{a}}$ & $3^{a}$ & $\begin{array}{c}2^{\mathbf{a}} \\
\text { Singular }\end{array}$ & $\begin{array}{c}1^{\mathrm{a}} \\
\text { Plural }\end{array}$ & $\begin{array}{c}2^{2} \\
\text { Plural }\end{array}$ \\
\hline Afirmativo & - & $\begin{array}{l}\text { Tu } \\
\text { come }\end{array}$ & $\begin{array}{l}\text { Ele } \\
\text { coma }\end{array}$ & $\begin{array}{l}\text { Nós } \\
\text { comamos }\end{array}$ & $\begin{array}{l}\text { Vós } \\
\text { comei }\end{array}$ & $\begin{array}{l}\text { Eles } \\
\text { comam }\end{array}$ & $\begin{array}{l}\text { Você } \\
\text { coma }\end{array}$ & $\begin{array}{l}\text { A gente } \\
\text { coma }\end{array}$ & $\begin{array}{l}\text { Vocês } \\
\text { comam }\end{array}$ \\
\hline Negativo & - & $\begin{array}{l}\text { Tu não } \\
\text { comas }\end{array}$ & $\begin{array}{l}\text { Ele não } \\
\text { coma }\end{array}$ & $\begin{array}{l}\text { Nós não } \\
\text { comamos }\end{array}$ & $\begin{array}{l}\text { Vós não } \\
\text { comais }\end{array}$ & $\begin{array}{l}\text { Eles não } \\
\text { comam }\end{array}$ & $\begin{array}{l}\text { Você não } \\
\text { coma }\end{array}$ & $\begin{array}{l}\text { A gente } \\
\text { não } \\
\text { coma }\end{array}$ & $\begin{array}{l}\text { Vocês } \\
\text { não } \\
\text { comam }\end{array}$ \\
\hline
\end{tabular}




\begin{tabular}{|c|c|c|c|c|c|c|c|c|c|}
\hline \multirow[b]{3}{*}{ Tempo } & \multicolumn{9}{|c|}{ Modo: Indicativo } \\
\hline & \multicolumn{3}{|c|}{ Singular } & \multicolumn{3}{|c|}{ Plural } & \multicolumn{3}{|c|}{ Informal } \\
\hline & $1^{a}$ & $2^{3}$ & $3^{a}$ & $1^{a}$ & $2^{a}$ & $3^{a}$ & $\begin{array}{c}\mathbf{2}^{\mathbf{a}} \\
\text { Singular }\end{array}$ & $\begin{array}{c}1^{a} \\
\text { Plural }\end{array}$ & $\begin{array}{c}\mathbf{2}^{\mathbf{a}} \\
\text { Plural }\end{array}$ \\
\hline Presente & $\begin{array}{l}\text { Eu } \\
\text { mato }\end{array}$ & $\begin{array}{l}\text { Tu } \\
\text { matas }\end{array}$ & $\begin{array}{l}\text { Ele } \\
\text { mata }\end{array}$ & $\begin{array}{l}\text { Nós } \\
\text { matamos }\end{array}$ & $\begin{array}{l}\text { Vós } \\
\text { matais }\end{array}$ & $\begin{array}{l}\text { Eles } \\
\text { matam }\end{array}$ & $\begin{array}{l}\text { Você } \\
\text { mata }\end{array}$ & $\begin{array}{l}\text { A gente } \\
\text { mata }\end{array}$ & $\begin{array}{l}\text { Vocês } \\
\text { matam }\end{array}$ \\
\hline $\begin{array}{l}\text { Pretérito } \\
\text { Imperfeito }\end{array}$ & $\begin{array}{l}\text { Eu } \\
\text { matava }\end{array}$ & $\begin{array}{l}\text { Tu } \\
\text { matavas }\end{array}$ & $\begin{array}{l}\text { Ele } \\
\text { matava }\end{array}$ & $\begin{array}{l}\text { Nós } \\
\text { matávamos }\end{array}$ & $\begin{array}{l}\text { Vós } \\
\text { matáveis }\end{array}$ & $\begin{array}{l}\text { Eles } \\
\text { matavam }\end{array}$ & $\begin{array}{l}\text { Você } \\
\text { matava }\end{array}$ & $\begin{array}{l}\text { A gente } \\
\text { matava }\end{array}$ & $\begin{array}{l}\text { Vocês } \\
\text { matavam }\end{array}$ \\
\hline $\begin{array}{l}\text { Pretérito } \\
\text { Perfeito }\end{array}$ & $\begin{array}{l}\text { Eu } \\
\text { matei }\end{array}$ & $\begin{array}{l}\text { Tu } \\
\text { mataste }\end{array}$ & $\begin{array}{l}\text { Ele } \\
\text { matou }\end{array}$ & $\begin{array}{l}\text { Nós } \\
\text { matamos }\end{array}$ & $\begin{array}{l}\text { Vós } \\
\text { matastes }\end{array}$ & $\begin{array}{l}\text { Eles } \\
\text { mataram }\end{array}$ & $\begin{array}{l}\text { Você } \\
\text { matou }\end{array}$ & $\begin{array}{l}\text { A gente } \\
\text { matou }\end{array}$ & $\begin{array}{l}\text { Vocês } \\
\text { mataram }\end{array}$ \\
\hline $\begin{array}{l}\text { Pretérito } \\
\text { mais que } \\
\text { Perfeito }\end{array}$ & $\begin{array}{l}\text { Eu } \\
\text { matara }\end{array}$ & $\begin{array}{l}\text { Tu } \\
\text { mataras }\end{array}$ & $\begin{array}{l}\text { Ele } \\
\text { matara }\end{array}$ & $\begin{array}{l}\text { Nós } \\
\text { matáramos }\end{array}$ & $\begin{array}{l}\text { Vós } \\
\text { matáreis }\end{array}$ & $\begin{array}{l}\text { Eles } \\
\text { mataram }\end{array}$ & $\begin{array}{l}\text { Você } \\
\text { matara }\end{array}$ & $\begin{array}{l}\text { A gente } \\
\text { matara }\end{array}$ & $\begin{array}{l}\text { Vocês } \\
\text { mataram }\end{array}$ \\
\hline $\begin{array}{l}\text { Futuro do } \\
\text { Pretérito }\end{array}$ & $\begin{array}{l}\text { Eu } \\
\text { mataria }\end{array}$ & $\begin{array}{l}\text { Tu } \\
\text { matarias }\end{array}$ & $\begin{array}{l}\text { Ele } \\
\text { mataria }\end{array}$ & $\begin{array}{l}\text { Nós } \\
\text { matariamos }\end{array}$ & $\begin{array}{l}\text { Vós } \\
\text { matarieis }\end{array}$ & $\begin{array}{l}\text { Eles } \\
\text { matariam }\end{array}$ & $\begin{array}{l}\text { Você } \\
\text { mataria }\end{array}$ & $\begin{array}{l}\text { A gente } \\
\text { mataria }\end{array}$ & $\begin{array}{l}\text { Vocês } \\
\text { matariam }\end{array}$ \\
\hline $\begin{array}{l}\text { Futuro do } \\
\text { Presente }\end{array}$ & $\begin{array}{l}\text { Eu } \\
\text { matarei }\end{array}$ & $\begin{array}{l}\text { Tu } \\
\text { matarás }\end{array}$ & $\begin{array}{l}\text { Ele } \\
\text { matará }\end{array}$ & $\begin{array}{l}\text { Nós } \\
\text { mataremos }\end{array}$ & $\begin{array}{l}\text { Vós } \\
\text { matareis }\end{array}$ & $\begin{array}{l}\text { Eles } \\
\text { matarão }\end{array}$ & $\begin{array}{l}\text { Você } \\
\text { matará }\end{array}$ & $\begin{array}{l}\text { A gente } \\
\text { matará }\end{array}$ & $\begin{array}{l}\text { Vocês } \\
\text { matarão }\end{array}$ \\
\hline
\end{tabular}

\begin{tabular}{|c|c|c|c|c|c|c|c|c|c|}
\hline \multirow[b]{3}{*}{ Tempo } & \multicolumn{9}{|c|}{ Modo: Subjuntivo } \\
\hline & \multicolumn{3}{|c|}{ Singular } & \multicolumn{3}{|c|}{ Plural } & \multicolumn{3}{|c|}{ Informal } \\
\hline & $1^{2}$ & $2^{\mathbf{a}}$ & $3^{a}$ & $1^{a}$ & $2^{a}$ & $3^{a}$ & $\begin{array}{c}2^{\mathbf{a}} \\
\text { Singular }\end{array}$ & $\begin{array}{c}1^{\mathbf{a}} \\
\text { Plural }\end{array}$ & $\begin{array}{c}2^{\mathrm{a}} \\
\text { Plural }\end{array}$ \\
\hline Presente & $\begin{array}{l}\text { Eu } \\
\text { mate }\end{array}$ & $\begin{array}{l}\text { Tu } \\
\text { mates }\end{array}$ & Ele mate & $\begin{array}{l}\text { Nós } \\
\text { matemos }\end{array}$ & $\begin{array}{l}\text { Vós } \\
\text { mateis }\end{array}$ & $\begin{array}{l}\text { Eles } \\
\text { matem }\end{array}$ & $\begin{array}{l}\text { Você } \\
\text { mate }\end{array}$ & $\begin{array}{l}\text { A gente } \\
\text { mate }\end{array}$ & $\begin{array}{l}\text { Vocês } \\
\text { matem }\end{array}$ \\
\hline Pretérito & $\begin{array}{l}\text { Eu } \\
\text { matasse }\end{array}$ & $\begin{array}{l}\text { Tu } \\
\text { matasses }\end{array}$ & $\begin{array}{l}\text { Ele } \\
\text { matasse }\end{array}$ & $\begin{array}{l}\text { Nós } \\
\text { matássemos }\end{array}$ & $\begin{array}{l}\text { Vós } \\
\text { matásseis }\end{array}$ & $\begin{array}{l}\text { Eles } \\
\text { matassem }\end{array}$ & $\begin{array}{l}\text { Você } \\
\text { matasse }\end{array}$ & $\begin{array}{l}\text { A gente } \\
\text { matasse }\end{array}$ & $\begin{array}{l}\text { Vocês } \\
\text { matassem }\end{array}$ \\
\hline Futuro & $\begin{array}{l}\text { Eu } \\
\text { matar }\end{array}$ & $\begin{array}{l}\text { Tu } \\
\text { matares }\end{array}$ & $\begin{array}{l}\text { Ele } \\
\text { matar }\end{array}$ & $\begin{array}{l}\text { Nós } \\
\text { matarmos }\end{array}$ & $\begin{array}{l}\text { Vós } \\
\text { matardes }\end{array}$ & $\begin{array}{l}\text { Eles } \\
\text { matares }\end{array}$ & $\begin{array}{l}\text { Você } \\
\text { matar }\end{array}$ & $\begin{array}{l}\text { A gente } \\
\text { matar }\end{array}$ & $\begin{array}{l}\text { Vocês } \\
\text { matarem }\end{array}$ \\
\hline
\end{tabular}




\begin{tabular}{|c|c|c|c|c|c|c|c|c|c|}
\hline & \multicolumn{9}{|c|}{ Modo: Imperativo } \\
\hline & \multicolumn{3}{|c|}{ Singular } & \multicolumn{3}{|c|}{ Plural } & \multicolumn{3}{|c|}{ Informal } \\
\hline & $1^{a}$ & $2^{a}$ & $3^{\mathbf{a}}$ & $1^{a}$ & $2^{\mathbf{a}}$ & $3^{a}$ & $\begin{array}{c}2^{\mathbf{a}} \\
\text { Singular }\end{array}$ & $\begin{array}{c}1^{a} \\
\text { Plural }\end{array}$ & $\begin{array}{c}2^{\mathbf{a}} \\
\text { Plural }\end{array}$ \\
\hline Afirmativo & - & $\begin{array}{l}\text { Tu } \\
\text { mata }\end{array}$ & $\begin{array}{l}\text { Ele } \\
\text { mate }\end{array}$ & $\begin{array}{l}\text { Nós } \\
\text { matemos }\end{array}$ & $\begin{array}{l}\text { Vós } \\
\text { matai }\end{array}$ & $\begin{array}{l}\text { Eles } \\
\text { matem }\end{array}$ & Você mate & $\begin{array}{l}\text { A gente } \\
\text { mate }\end{array}$ & $\begin{array}{l}\text { Vocês } \\
\text { matem }\end{array}$ \\
\hline Negativo & - & $\begin{array}{l}\text { Não } \\
\text { mates tu }\end{array}$ & $\begin{array}{l}\text { Não } \\
\text { mate } \\
\text { ele }\end{array}$ & $\begin{array}{l}\text { Não } \\
\text { matemos } \\
\text { nós }\end{array}$ & $\begin{array}{l}\text { Não } \\
\text { mateis } \\
\text { vós }\end{array}$ & $\begin{array}{l}\text { Não } \\
\text { matem } \\
\text { eles }\end{array}$ & $\begin{array}{l}\text { Não mate } \\
\text { você }\end{array}$ & $\begin{array}{l}\text { Não } \\
\text { mate a } \\
\text { gente }\end{array}$ & $\begin{array}{l}\text { Não } \\
\text { matem } \\
\text { vocês }\end{array}$ \\
\hline
\end{tabular}

\begin{tabular}{|c|c|c|c|c|c|c|c|c|c|}
\hline \multirow[b]{3}{*}{ Tempo } & \multicolumn{9}{|c|}{ Modo: Indicativo } \\
\hline & \multicolumn{3}{|c|}{ Singular } & \multicolumn{3}{|c|}{ Plural } & \multicolumn{3}{|c|}{ Informal } \\
\hline & $1^{2}$ & $2^{3}$ & $3^{a}$ & $1^{a}$ & $2^{\mathrm{a}}$ & $3^{a}$ & $\begin{array}{c}2^{\mathbf{a}} \\
\text { Singular }\end{array}$ & $\begin{array}{c}1^{\mathbf{a}} \\
\text { Plural }\end{array}$ & $\begin{array}{c}2^{\mathbf{a}} \\
\text { Plural }\end{array}$ \\
\hline Presente & $\begin{array}{l}{ }^{*} \mathrm{Eu} \\
\text { visto }\end{array}$ & $\begin{array}{l}\text { Tu } \\
\text { vestes }\end{array}$ & $\begin{array}{l}\text { Ele } \\
\text { veste }\end{array}$ & $\begin{array}{l}\text { Nós } \\
\text { vestimos }\end{array}$ & $\begin{array}{l}\text { Vós } \\
\text { vestis }\end{array}$ & $\begin{array}{l}\text { Eles } \\
\text { vestem }\end{array}$ & $\begin{array}{l}\text { Você } \\
\text { veste }\end{array}$ & $\begin{array}{l}\text { A gente } \\
\text { veste }\end{array}$ & $\begin{array}{l}\text { Eles } \\
\text { vestem }\end{array}$ \\
\hline $\begin{array}{l}\text { Pretérito } \\
\text { Imperfeito }\end{array}$ & $\begin{array}{l}{ }^{\star} \text { Eu } \\
\text { vestia }\end{array}$ & $\begin{array}{l}\text { Tu } \\
\text { vestias }\end{array}$ & $\begin{array}{l}\text { Ele } \\
\text { vestia }\end{array}$ & $\begin{array}{l}\text { Nós } \\
\text { vestíamos }\end{array}$ & $\begin{array}{l}\text { Vós } \\
\text { vestíeis }\end{array}$ & $\begin{array}{l}\text { Eles } \\
\text { vestiam }\end{array}$ & $\begin{array}{l}\text { Você } \\
\text { vestia }\end{array}$ & $\begin{array}{l}\text { A gente } \\
\text { vestia }\end{array}$ & $\begin{array}{l}\text { Vocês } \\
\text { vestiam }\end{array}$ \\
\hline $\begin{array}{l}\text { Pretérito } \\
\text { Perfeito }\end{array}$ & $\begin{array}{l}{ }^{*} \text { Eu } \\
\text { vesti }\end{array}$ & $\begin{array}{l}\text { Tu } \\
\text { vestiste }\end{array}$ & $\begin{array}{l}\text { Ele } \\
\text { vestiu }\end{array}$ & $\begin{array}{l}\text { Nós } \\
\text { vestimos }\end{array}$ & $\begin{array}{l}\text { Vós } \\
\text { vestistes }\end{array}$ & $\begin{array}{l}\text { Eles } \\
\text { vestiram }\end{array}$ & $\begin{array}{l}\text { Você } \\
\text { vestiu }\end{array}$ & $\begin{array}{l}\text { A gente } \\
\text { vestiu }\end{array}$ & $\begin{array}{l}\text { Vocês } \\
\text { vestiram }\end{array}$ \\
\hline $\begin{array}{l}\text { Pretérito } \\
\text { mais que } \\
\text { Perfeito }\end{array}$ & $\begin{array}{l}{ }^{\star} \mathrm{Eu} \\
\text { vestira }\end{array}$ & $\begin{array}{l}\text { Tu } \\
\text { vestiras }\end{array}$ & $\begin{array}{l}\text { Ele } \\
\text { vestira }\end{array}$ & $\begin{array}{l}\text { Nós } \\
\text { vestíramos }\end{array}$ & $\begin{array}{l}\text { Vós } \\
\text { vestíreis }\end{array}$ & $\begin{array}{l}\text { Eles } \\
\text { vestiram }\end{array}$ & $\begin{array}{l}\text { Você } \\
\text { vestira }\end{array}$ & $\begin{array}{l}\text { A gente } \\
\text { vestira }\end{array}$ & $\begin{array}{l}\text { Vocês } \\
\text { vestiram }\end{array}$ \\
\hline $\begin{array}{l}\text { Futuro do } \\
\text { Pretérito }\end{array}$ & $\begin{array}{l}{ }^{*} \text { Eu } \\
\text { vestiria }\end{array}$ & $\begin{array}{l}\text { Tu } \\
\text { vestirias }\end{array}$ & $\begin{array}{l}\text { Ele } \\
\text { vestiria }\end{array}$ & $\begin{array}{l}\text { Nós } \\
\text { vestiríamos }\end{array}$ & $\begin{array}{l}\text { Vós } \\
\text { vestirieis }\end{array}$ & $\begin{array}{l}\text { Eles } \\
\text { vestiriam }\end{array}$ & $\begin{array}{l}\text { Você } \\
\text { vestiria }\end{array}$ & $\begin{array}{l}\text { A gente } \\
\text { vestiria }\end{array}$ & $\begin{array}{l}\text { Vocês } \\
\text { vestiriam }\end{array}$ \\
\hline $\begin{array}{l}\text { Futuro do } \\
\text { Presente }\end{array}$ & $\begin{array}{l}{ }^{*} \text { Eu } \\
\text { vestirei }\end{array}$ & $\begin{array}{l}\text { Tu } \\
\text { vestirás }\end{array}$ & $\begin{array}{l}\text { Ele } \\
\text { vestirá }\end{array}$ & $\begin{array}{l}\text { Nós } \\
\text { vestiremos }\end{array}$ & $\begin{array}{l}\text { Vós } \\
\text { vestireis }\end{array}$ & $\begin{array}{l}\text { Eles } \\
\text { vestirão }\end{array}$ & $\begin{array}{l}\text { Você } \\
\text { vestirá }\end{array}$ & $\begin{array}{l}\text { A gente } \\
\text { vestirá }\end{array}$ & $\begin{array}{l}\text { Vocês } \\
\text { vestirão }\end{array}$ \\
\hline
\end{tabular}




\begin{tabular}{|c|c|c|c|c|c|c|c|c|c|}
\hline \multirow[b]{3}{*}{ Tempo } & \multicolumn{9}{|c|}{ Modo: Subjuntivo } \\
\hline & \multicolumn{3}{|c|}{ Singular } & \multicolumn{3}{|c|}{ Plural } & \multicolumn{3}{|c|}{ Informal } \\
\hline & $1^{3}$ & $2^{3}$ & $3^{\mathbf{a}}$ & $1^{a}$ & $2^{3}$ & $3^{a}$ & $\begin{array}{c}2^{3} \\
\text { Singular }\end{array}$ & $\begin{array}{c}1^{a} \\
\text { Plural }\end{array}$ & $\begin{array}{c}\mathbf{2}^{\mathbf{a}} \\
\text { Plural }\end{array}$ \\
\hline Presente & $\begin{array}{l}{ }^{*} \mathrm{Eu} \\
\text { vista }\end{array}$ & Tu vistas & Ele vista & $\begin{array}{l}\text { Nós } \\
\text { vistamos }\end{array}$ & $\begin{array}{l}\text { Vós } \\
\text { vistais }\end{array}$ & $\begin{array}{l}\text { Eles } \\
\text { vistam }\end{array}$ & $\begin{array}{l}\text { Você } \\
\text { vista }\end{array}$ & $\begin{array}{l}\text { A gente } \\
\text { vista }\end{array}$ & $\begin{array}{l}\text { Vocês } \\
\text { vistam }\end{array}$ \\
\hline Pretérito & $\begin{array}{l}{ }^{*} \text { Eu } \\
\text { vestisse }\end{array}$ & $\begin{array}{l}\text { Tu } \\
\text { vestisses }\end{array}$ & $\begin{array}{l}\text { Ele } \\
\text { vestisse }\end{array}$ & $\begin{array}{l}\text { Nós } \\
\text { vestíssemos }\end{array}$ & $\begin{array}{l}\text { Vós } \\
\text { vestísseis }\end{array}$ & $\begin{array}{l}\text { Eles } \\
\text { vestissem }\end{array}$ & $\begin{array}{l}\text { Você } \\
\text { vestisse }\end{array}$ & $\begin{array}{l}\text { A gente } \\
\text { vestisse }\end{array}$ & $\begin{array}{l}\text { Vocês } \\
\text { vestissem }\end{array}$ \\
\hline Futuro & $\begin{array}{l}{ }^{*} \mathrm{Eu} \\
\text { vestir }\end{array}$ & $\begin{array}{l}\text { Tu } \\
\text { vestires }\end{array}$ & $\begin{array}{l}\text { Ele } \\
\text { vestir }\end{array}$ & $\begin{array}{l}\text { Nós } \\
\text { vestirmos }\end{array}$ & $\begin{array}{l}\text { Vós } \\
\text { vestirdes }\end{array}$ & $\begin{array}{l}\text { Eles } \\
\text { vestirem }\end{array}$ & $\begin{array}{l}\text { Você } \\
\text { vestir }\end{array}$ & $\begin{array}{l}\text { A gente } \\
\text { vestir }\end{array}$ & $\begin{array}{l}\text { Vocês } \\
\text { vestirem }\end{array}$ \\
\hline
\end{tabular}

\begin{tabular}{|c|c|c|c|c|c|c|c|c|c|}
\hline & \multicolumn{9}{|c|}{ Modo: Imperativo } \\
\hline & \multicolumn{3}{|c|}{ Singular } & \multicolumn{3}{|c|}{ Plural } & \multicolumn{3}{|c|}{ Informal } \\
\hline & $1^{2}$ & $2^{a}$ & $3^{a}$ & $1^{2}$ & $2^{a}$ & $3^{a}$ & $\begin{array}{c}\mathbf{2}^{\mathbf{a}} \\
\text { Singular }\end{array}$ & $\begin{array}{c}1^{\mathbf{a}} \\
\text { Plural }\end{array}$ & $\begin{array}{c}2^{\mathbf{a}} \\
\text { Plural }\end{array}$ \\
\hline Afirmativo & *- & Tu veste & $\begin{array}{l}\text { Ele } \\
\text { vesta }\end{array}$ & $\begin{array}{l}\text { Nós } \\
\text { vistamos }\end{array}$ & Vós visti & $\begin{array}{l}\text { Eles } \\
\text { vistam }\end{array}$ & Você vista & $\begin{array}{l}\text { A gente } \\
\text { vista }\end{array}$ & $\begin{array}{l}\text { Vocês } \\
\text { vistam }\end{array}$ \\
\hline Negativo & *- & $\begin{array}{l}\text { Não } \\
\text { vistas tu }\end{array}$ & $\begin{array}{l}\text { Não } \\
\text { vista ele }\end{array}$ & $\begin{array}{l}\text { Não } \\
\text { vistamos } \\
\text { nós }\end{array}$ & $\begin{array}{l}\text { Não } \\
\text { vistais } \\
\text { vós }\end{array}$ & $\begin{array}{l}\text { Não } \\
\text { vistam } \\
\text { eles }\end{array}$ & $\begin{array}{l}\text { Não vista } \\
\text { você }\end{array}$ & $\begin{array}{l}\text { Não } \\
\text { viata a } \\
\text { gente }\end{array}$ & $\begin{array}{l}\text { não } \\
\text { vistam } \\
\text { vocês }\end{array}$ \\
\hline
\end{tabular}




\begin{tabular}{|c|c|c|c|c|c|c|c|c|c|}
\hline \multirow[b]{3}{*}{ Tempo } & \multicolumn{9}{|c|}{ Modo: Indicativo } \\
\hline & \multicolumn{3}{|c|}{ Singular } & \multicolumn{3}{|c|}{ Plural } & \multicolumn{3}{|c|}{ Informal } \\
\hline & $1^{a}$ & $2^{2}$ & $3^{\mathbf{a}}$ & $1^{a}$ & $2^{3}$ & $3^{a}$ & $\begin{array}{c}2^{\mathbf{a}} \\
\text { Singular }\end{array}$ & $\begin{array}{c}1^{\mathrm{a}} \\
\text { Plural }\end{array}$ & $\begin{array}{c}\mathbf{2}^{\mathbf{a}} \\
\text { Plural }\end{array}$ \\
\hline Presente & $\begin{array}{l}\mathrm{Eu} \\
\text { tomo }\end{array}$ & $\begin{array}{l}\text { Tu } \\
\text { tomas }\end{array}$ & $\begin{array}{l}\text { Ele } \\
\text { toma }\end{array}$ & $\begin{array}{l}\text { Nós } \\
\text { tomamos }\end{array}$ & $\begin{array}{l}\text { Vós } \\
\text { tomais }\end{array}$ & $\begin{array}{l}\text { Eles } \\
\text { tomam }\end{array}$ & $\begin{array}{l}\text { Você } \\
\text { toma }\end{array}$ & $\begin{array}{l}\text { A gente } \\
\text { toma }\end{array}$ & $\begin{array}{l}\text { Vocês } \\
\text { tomam }\end{array}$ \\
\hline $\begin{array}{l}\text { Pretérito } \\
\text { Imperfeito }\end{array}$ & $\begin{array}{l}\text { Eu } \\
\text { tomava }\end{array}$ & $\begin{array}{l}\text { Tu } \\
\text { tomavas }\end{array}$ & $\begin{array}{l}\text { Ele } \\
\text { tomava }\end{array}$ & $\begin{array}{l}\text { Nós } \\
\text { tomávamos }\end{array}$ & $\begin{array}{l}\text { Vós } \\
\text { tomáveis }\end{array}$ & $\begin{array}{l}\text { Eles } \\
\text { tomavam }\end{array}$ & $\begin{array}{l}\text { Você } \\
\text { tomava }\end{array}$ & $\begin{array}{l}\text { A gente } \\
\text { tomava }\end{array}$ & $\begin{array}{l}\text { Vocês } \\
\text { tomavam }\end{array}$ \\
\hline $\begin{array}{l}\text { Pretérito } \\
\text { Perfeito }\end{array}$ & $\begin{array}{l}\text { Eu } \\
\text { tomei }\end{array}$ & $\begin{array}{l}\text { Tu } \\
\text { tomaste }\end{array}$ & $\begin{array}{l}\text { Ele } \\
\text { tomou }\end{array}$ & $\begin{array}{l}\text { Nós } \\
\text { tomamos }\end{array}$ & $\begin{array}{l}\text { Vós } \\
\text { tomastes }\end{array}$ & $\begin{array}{l}\text { Eles } \\
\text { tomaram }\end{array}$ & $\begin{array}{l}\text { Você } \\
\text { tomou }\end{array}$ & $\begin{array}{l}\text { A gente } \\
\text { tomou }\end{array}$ & $\begin{array}{l}\text { Vocês } \\
\text { tomaram }\end{array}$ \\
\hline $\begin{array}{l}\text { Pretérito } \\
\text { mais que } \\
\text { Perfeito }\end{array}$ & $\begin{array}{l}\text { Eu } \\
\text { tomara }\end{array}$ & $\begin{array}{l}\text { Tu } \\
\text { tomaras }\end{array}$ & $\begin{array}{l}\text { Ele } \\
\text { tomara }\end{array}$ & $\begin{array}{l}\text { Nós } \\
\text { tomáramos }\end{array}$ & $\begin{array}{l}\text { Vós } \\
\text { tomáreis }\end{array}$ & $\begin{array}{l}\text { Eles } \\
\text { tomaram }\end{array}$ & $\begin{array}{l}\text { Você } \\
\text { tomara }\end{array}$ & $\begin{array}{l}\text { A gente } \\
\text { tomara }\end{array}$ & $\begin{array}{l}\text { Vocês } \\
\text { tomaram }\end{array}$ \\
\hline $\begin{array}{l}\text { Futuro do } \\
\text { Pretérito }\end{array}$ & $\begin{array}{l}\text { Eu } \\
\text { tomaria }\end{array}$ & $\begin{array}{l}\text { Tu } \\
\text { tomarias }\end{array}$ & $\begin{array}{l}\text { Ele } \\
\text { tomaria }\end{array}$ & $\begin{array}{l}\text { Nós } \\
\text { tomariamos }\end{array}$ & $\begin{array}{l}\text { Vós } \\
\text { tomarieis }\end{array}$ & $\begin{array}{l}\text { Eles } \\
\text { tomariam }\end{array}$ & $\begin{array}{l}\text { Você } \\
\text { tomaria }\end{array}$ & $\begin{array}{l}\text { A gente } \\
\text { tomaria }\end{array}$ & $\begin{array}{l}\text { Vocês } \\
\text { tomariam }\end{array}$ \\
\hline $\begin{array}{l}\text { Futuro do } \\
\text { Presente }\end{array}$ & $\begin{array}{l}\text { Eu } \\
\text { tomarei }\end{array}$ & $\begin{array}{l}\text { Tu } \\
\text { tomarás }\end{array}$ & $\begin{array}{l}\text { Ele } \\
\text { tomará }\end{array}$ & $\begin{array}{l}\text { Nós } \\
\text { tomaremos }\end{array}$ & $\begin{array}{l}\text { Vós } \\
\text { tomareis }\end{array}$ & $\begin{array}{l}\text { Eles } \\
\text { tomarão }\end{array}$ & $\begin{array}{l}\text { Você } \\
\text { tomará }\end{array}$ & $\begin{array}{l}\text { A gente } \\
\text { tomará }\end{array}$ & $\begin{array}{l}\text { Vocês } \\
\text { tomarão }\end{array}$ \\
\hline
\end{tabular}

\begin{tabular}{|c|c|c|c|c|c|c|c|c|c|}
\hline \multirow[b]{3}{*}{ Tempo } & \multicolumn{9}{|c|}{ Modo: Subjuntivo } \\
\hline & \multicolumn{3}{|c|}{ Singular } & \multicolumn{3}{|c|}{ Plural } & \multicolumn{3}{|c|}{ Informal } \\
\hline & $1^{2}$ & $2^{\mathrm{a}}$ & $3^{a}$ & $1^{a}$ & $2^{\mathrm{a}}$ & $3^{a}$ & $\begin{array}{c}\mathbf{2}^{\mathbf{a}} \\
\text { Singular }\end{array}$ & $\begin{array}{c}1^{\mathrm{a}} \\
\text { Plural }\end{array}$ & $\begin{array}{c}2^{\mathbf{a}} \\
\text { Plural }\end{array}$ \\
\hline Presente & $\begin{array}{l}\mathrm{Eu} \\
\text { tome }\end{array}$ & $\begin{array}{l}\text { Tu } \\
\text { tomes }\end{array}$ & Ele tome & $\begin{array}{l}\text { Nós } \\
\text { tomemos }\end{array}$ & $\begin{array}{l}\text { Vós } \\
\text { tomeis }\end{array}$ & $\begin{array}{l}\text { Eles } \\
\text { tomem }\end{array}$ & $\begin{array}{l}\text { Você } \\
\text { tome }\end{array}$ & $\begin{array}{l}\text { A gente } \\
\text { tome }\end{array}$ & $\begin{array}{l}\text { Vocês } \\
\text { tomem }\end{array}$ \\
\hline Pretérito & $\begin{array}{l}\text { Eu } \\
\text { tomasse }\end{array}$ & $\begin{array}{l}\text { Tu } \\
\text { tomasses }\end{array}$ & $\begin{array}{l}\text { Ele } \\
\text { tomasse }\end{array}$ & $\begin{array}{l}\text { Nós } \\
\text { tomássemos }\end{array}$ & $\begin{array}{l}\text { Vós } \\
\text { tomásseis }\end{array}$ & $\begin{array}{l}\text { Eles } \\
\text { tomassem }\end{array}$ & $\begin{array}{l}\text { Você } \\
\text { tomasse }\end{array}$ & $\begin{array}{l}\text { A gente } \\
\text { tomasse }\end{array}$ & $\begin{array}{l}\text { Vocês } \\
\text { tomassem }\end{array}$ \\
\hline Futuro & $\begin{array}{l}\text { Eu } \\
\text { tomar }\end{array}$ & $\begin{array}{l}\text { Tu } \\
\text { tomares }\end{array}$ & $\begin{array}{l}\text { Eles } \\
\text { tomar }\end{array}$ & $\begin{array}{l}\text { Nós } \\
\text { tomarmos }\end{array}$ & $\begin{array}{l}\text { Vós } \\
\text { tomardes }\end{array}$ & $\begin{array}{l}\text { Eles } \\
\text { tomarem }\end{array}$ & $\begin{array}{l}\text { Você } \\
\text { tomar }\end{array}$ & $\begin{array}{l}\text { A gente } \\
\text { tomar }\end{array}$ & $\begin{array}{l}\text { Vocês } \\
\text { tomarem }\end{array}$ \\
\hline
\end{tabular}




\begin{tabular}{|c|c|c|c|c|c|c|c|c|c|}
\hline & \multicolumn{9}{|c|}{ Modo: Imperativo } \\
\hline & \multicolumn{3}{|c|}{ Singular } & \multicolumn{3}{|c|}{ Plural } & \multicolumn{3}{|c|}{ Informal } \\
\hline & $1^{a}$ & $2^{3}$ & $3^{\mathbf{a}}$ & $1^{a}$ & $2^{\mathrm{a}}$ & $3^{\mathbf{a}}$ & $\begin{array}{c}2^{\mathbf{a}} \\
\text { Singular }\end{array}$ & $\begin{array}{c}1^{\mathbf{a}} \\
\text { Plural }\end{array}$ & $\begin{array}{c}2^{\mathbf{a}} \\
\text { Plural }\end{array}$ \\
\hline Afirmativo & - & $\begin{array}{l}\text { Tu } \\
\text { toma }\end{array}$ & $\begin{array}{l}\text { Ele } \\
\text { tome }\end{array}$ & $\begin{array}{l}\text { Nós } \\
\text { tomemos }\end{array}$ & Vós tomai & $\begin{array}{l}\text { Eles } \\
\text { tomem }\end{array}$ & Você tome & $\begin{array}{l}\text { A gente } \\
\text { tome }\end{array}$ & $\begin{array}{l}\text { Vocês } \\
\text { tomem }\end{array}$ \\
\hline Negativo & - & $\begin{array}{l}\text { Não } \\
\text { tomes tu }\end{array}$ & $\begin{array}{l}\text { Não } \\
\text { tome } \\
\text { ele }\end{array}$ & $\begin{array}{l}\text { Não } \\
\text { tomemos } \\
\text { nós }\end{array}$ & $\begin{array}{l}\text { Não } \\
\text { tomeis vós }\end{array}$ & $\begin{array}{l}\text { Não } \\
\text { tomem } \\
\text { eles }\end{array}$ & $\begin{array}{l}\text { Não tome } \\
\text { você }\end{array}$ & $\begin{array}{l}\text { Não } \\
\text { tome a } \\
\text { gente }\end{array}$ & $\begin{array}{l}\text { Não } \\
\text { tomem } \\
\text { vocês }\end{array}$ \\
\hline
\end{tabular}

